\title{
TAXONOMIA FOLK E DIVERSIDADE INTRAESPECÍFICA DE MANDIOCA (Manihot esculenta Crantz) EM ROÇAS DE AGRICULTURA TRADICIONAL EM ÁREAS DE MATA ATLÂNTICA DO SUL DO ESTADO DE SÃO PAULO
}

NIVALDO PERONI

Engenheiro Agrônomo

Orientador: Prof. Dr. Akihiko Ando

\begin{abstract}
Dissertação apresentada à Escola Superior de Agricultura "Luiz de Queiroz", Universidade de São Paulo, para obtenção do título de Mestre em Agronomia, Área de Concentração: Genética e Melhoramento de Plantas
\end{abstract}

PIRACICABA Estado de São Paulo - Brasil Abril - 1998 


\begin{tabular}{|c|c|c|}
\hline $\begin{array}{l}\text { Localização } \\
\text { (p=página, } \\
\S=\text { parágrafo, } \\
\text { =linha) }\end{array}$ & Onde se lê & Leia-se \\
\hline$p .12, \S 2, \ell 6$ & (Clemente, 1995) & (Clément, 1995) \\
\hline p.16, $\S 1, \ell 20$ & Amurrio (1993) & Amurrio et al. (1993) \\
\hline$p .16, \S 2, \ell 3$ & Ceccarelli (1991) & Ceccarelli \& Grando (1991) \\
\hline p. $18, \S 2, \ell 16$ & Ney, 1990 & Ney, 1991 \\
\hline p.21, $\S 1, \ell 8$ & Citrullus lunatus & Citrullus lanatus \\
\hline p. $29, \S 2, \ell 4$ & 30 amostradas eram coletadas & 30 indivíduos amostrados eram coletados \\
\hline$p .47, \S 1, \ell 2$ & no empregado & no emprego \\
\hline p.47, § 4, ८2 & "Simple Mathing" & "Simple Matching" \\
\hline$p .49, \S 2, \ell 2$ & Friedman \& Rubi (1967) & Friedman \& Rubin (1967) \\
\hline p.52, §1, ८4 & (Culloch, 1990) & (James \& MacCulloch, 1990) \\
\hline p. $57, \S 2, \ell 9$ & são plantadas misturas & são plantadas misturadas \\
\hline$p .82, \S 1, \ell 10$ & e a hipoteticamente & e hipoteticamente \\
\hline p.87, § $3, \ell 2$ & correlação cofenética Tabela 8 & correlação cofenética (Tabela 9) \\
\hline p.101, $\S 1, \ell 7$ & sugerem se ter dimensões & sugere ter dimensōes \\
\hline$p .124, \S 2, \iota 3$ & apenas se confirma & apenas se deduz \\
\hline p.127, § $1, \ell 1$ & $\begin{array}{l}\text { existem mais de um genótipo para } \\
\text { cada variedade }\end{array}$ & $\begin{array}{l}\text { existem variedades com mais de um } \\
\text { genótipo }\end{array}$ \\
\hline p.133, $\S 3, \ell 1$ & Nas figuras 51,52 e 53 & Nas figuras 51 e 52 \\
\hline p.135, § $1, \ell 4$ & $\begin{array}{l}\text { evidente que } 3 \text { clones de um } \\
\text { genótipo de "aipim roxo" AR(2), } \\
\text { sāo claramente separados }\end{array}$ & $\begin{array}{l}\text { evidente que I clone de um genótipo de } \\
\text { "aipim roxo" AR(2), é claramente separado }\end{array}$ \\
\hline p. $150, \S 2, \ell 9$ & praticamente idênticos. & praticamente idênticos morfologicamente \\
\hline $\begin{array}{l}\text { p.166, la citação } \\
\text { Apêndices } 3,4,5,6 \mathrm{e} \\
7\end{array}$ & $\begin{array}{l}\text { Romão, R.L. (Citrullus lunatus) } \\
\text { distância euclideana }\end{array}$ & $\begin{array}{l}\text { Romão, R.L. (Citrullus lanatus) } \\
\text { distância euclidiana }\end{array}$ \\
\hline Apêndices 27 e 28 & similariedades & similaridades \\
\hline
\end{tabular}

Referências bibliográficas faltando:

BRUSH, S. Genetic diversity and conservation in traditional farming systems. Journal of Ethnobiology, n.6, p.151-167, 1986.

FRIEDMAN, H.P.;RUBIN, J. On some invariant criteria for grouping data. Journal of American Statistical Association, v.62, p.1159-1178, 1967.

HUNN, E. The utilitarian factor in folk biological classification. American Anthropologist, n.84, p.830-847, 1982.

RIBOLDI, J. Análise de agrupamento "cluster analysis" e suas aplicaçōes, Piracicaba, Departamento de Estatística/ESALQ, 1986. 33p.

ROHLF, F.J., FISCHER, D.R. Tests for hierarchical structure in random data sets. Systematics Zoology, n.17, p.407-412, 1968. 
Dados Internacionais de Catalogação na Publicação (CIP)

DIVISĀO DE BIBLIOTECA E DOCUMENTAÇĀO - Campus "Luiz de Queiroz"/USP

Peroni, Nivaldo

Taxonomia folk e diversidade intraespecifica de mandioca (Manihot esculenta, Crantz) em roças de agricultura tradicional em áreas de Mata Atlântica do sul do Estado de São Paulo / Nivaldo Peroni. - - Piracicaba, 1998.

$191 \mathrm{p}$.

Dissertação (mestrado) - - Escola Superior de Agricultura Luiz de Queiroz, 1998. Bibliografia.

1. Classificação (Biologia) 2. Lavoura 3. Mandioca 4. Melhoramento vegetal 5. Recurso genético 6 . Variabilidade genètica I. Título 
Com esta dissertação acabada, gostaria de agradecer e prestar minha homenagem ao Prof. Paulo Sodero Martins (in memoriam).

Apesar dele não estar presente, fico feliz em terminar um trabalho que envolveu um esforço conjunto.

Fico feliz pela oportunidade de ter trabalhado com o Paulo e continuar "colhendo" os frutos do que aprendi com ele. Acredito que está é uma excelente herança. A herança do aprendizado, das ferramentas para o trabalho, do saber e do querer fazer.

Fico feliz pelas oportunidades que ele me proporcionou direta e indiretamente para meu desenvolvimento profissional e pessoal.

Fico feliz por ter compartilhado com sua familia (Lurdinha e suas Aninhas) de bons e felizes momentos.

Fico feliz por ter sido orientado por ele, pela nossa amizade, pela sua generosidade e por sentir sua presença sempre.

Obrigado "Dr. Paulinho" , o trabalho continua. 
A minha familia dedico, especialmente a meus pais Luiz Marcos Peroni e Wilma Bressan Peroni, que não mediram esforços para minha formação.

Aos meus amores Natalia e Pedro ofereço 
Agradeço ao Departamento de Genética da ESALQ/USP pela oportunidade de realização do trabalho.

A Paulo Sodero Martins pela orientação, pela amizade, e incentivo ao meu trabalho.

Ao Prof. Dr. Akihiko Ando pela amizade e pela grande disposiçāo em dar todas as condições necessárias para o término desta dissertação.

Ao Conselho Nacional de Pesquisa (CNPq) e à Fundação de Amparo à Pesquisa do Estado de São Paulo (FAPESP) pelo apoio financeiro.

Aos agricultores José Coelho, Quirino Coelho e Florêncio Coelho, de Ariri, e a famila Camargo de Praia Grande, pela acolhida em suas casas, pela confiança despejada em $\mathrm{mim}$ e pelos ensinamentos sobre os "caminhos" da roça.

À banca julgadora pela disponibilidade e atenção ao trabalho, e ao Prof. Dr. George Shepherd, pela ajuda nas discussões finais.

Aos professores do curso de Genética e Melhoramento de Plantas, em especial ao Prof. Roland Vencovski.

Aos alunos e amigos do Departamento de Genética, especialmente aos companheiros do Laboratório de Genética Ecológica: Julianno, Rainério, Gilda, Luciana, Fábio, Ednei, Elias, Roberto 
Cury, Roberto Romão, Carlos "maledeto", Geraldo, Inez e Beth, por todos os momentos juntos.

Aos "componentes" da minha turma de mestrado Ana Claúdia C. Badan, pela amizade e pelo apoio constante.

Aos funcionários do Departamento de Genética, principalmente a Zé Monteiro e Norberto pelo auxilio nas viagens. E especialmente ao técnico do Laboratório de Genética Ecológica Ronaldo J. Rabello pelo auxilio e companherismo em todas as etapas deste trabalho.

Aos funcionários da Biblioteca Central em especial à Silvana e Fátima e às funcionárias da Biblioteca do Departamento de Genética da ESALQ. Beth e Silvana.

A Natalia, pela grandiosa paciência, incentivo e apoio em todas as horas.

E finalmente gostaria de agradecer a Lou Reed, Tom Waits, Black Grape, Caetano Veloso, Gil, Paulo Leminski, Dire Straits, e a um tal Mozart, pelos momentos de companhia e descontração. 
SUMÁRIO

Página

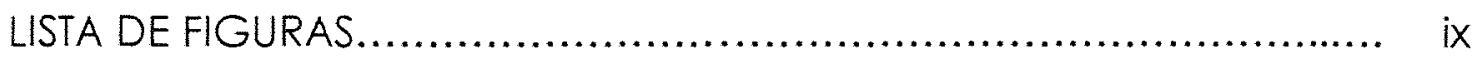

LISTA DE TABELAS........................................................ xvii

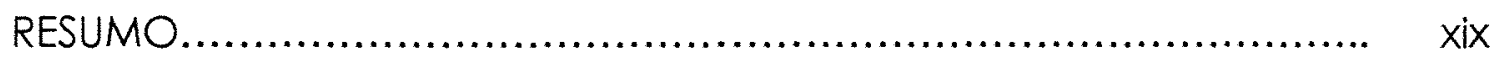

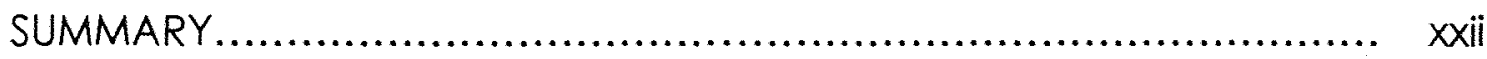

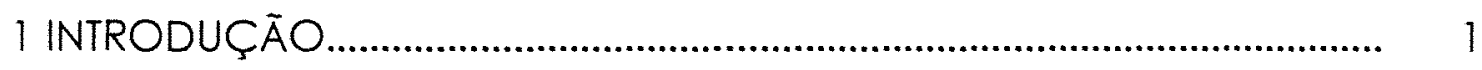

2 REVISĀO DE LITERATURA ................................................................... 5

2.1 Agricultura tradicional................................................................... 5

2.2 Agricultura de corte e queima, de coivara ou itinerante................ 8

2.3 Diversidade intraespecífica em roças de agricultura tradicional (etnovariedades), e taxonomia folk........................................................... 9

2.40 papel das etnovariedades para a agricultura moderna,

para os estudos evolutivos e para as comunidades

tradicionais de agricultores......................................................................... 14

2.5 A espécie Manihot esculenta Crantz.................................................. 17

2.6 Documentos históricos............................................................................. 21

3 MATERIAL E MÉTODOS........................................................................... 26

3.1 Reconhecimento dos locais................................................................. 26

3.2 Coleta de germoplasma......................................................................... 28

3.2.1 Comunidade de Ariri................................................................ 28

3.2.2 Comunidade de Praia Grande .............................................. 31

3.3 Ensaios de campo para a avaliação morfológica e para a eletroforese de isoenzimas. 
3.4 Descritores botânicos avaliados......................................................... 34

3.5 Eletroforese de isoenzimas.................................................................. 38

3.5.1 Escolha dos sistemas enzimáticos.......................................... 38

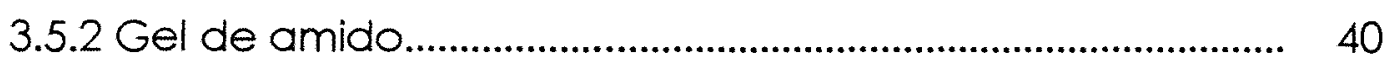

3.5.3 Extração, aplicação das amostras e revelação................... 41

3.6 Métodos analíticos.................................................................................... 46

3.6.1 Distância Euclidiana Média........................................................ 46

3.6.2 Cálculo do indice de similaridade genética

Coeficiente de semelhança simples ("Simple Matching")......... 46

3.6.3 Análise de agrupamento........................................................ 48

3.6.3.1 Número de grupos formados..................................... 49

3.6.3.2 Coeficiente de correlação cofenético..................... 50

3.6.4 Análise de componentes principais (PCA).............................. 51

3.6.5 Análise de coordenadas principais (PCO).......................... 52

3.6.6 Correlação de matrizes - Teste de Mantel. ........................... 53

3.7 Programas de computador utilizados para as análises................... 54

4 RESULTADOS E DISCUSSÃO .................................................................... 56

4.1 Descrição dos locais.............................................................................. 56

4.1.1 Comunidade de Praia Grande. ........................................... 57

4.1.2. Comunidade de Ariri.............................................................. 58

4.1.3 Classes vegetacionais diferenciados pelo agricultor. ........ 64

4.1.4 Demografia.............................................................................. 66

4.1.5 Variedades coletadas para análise, especificidades

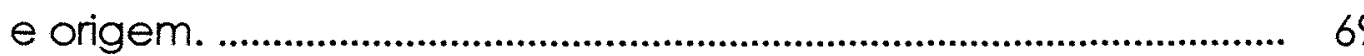


4.2 Análise multivariada. Relações entre as etnovariedades e indivíduos, baseadas em dados morfológicos........................................... 74

4.2.1 Distância euclidiana média e agrupamentos....................... 74 4.2.1.1 Análise de Agrupamento das variedades em nivel de roça de Ariril ..................................................... 76

4.2.1.2 Análise de Agrupamento das variedades em nivel de roça de Ariri2 ................................................................. 83

4.2.1.2.1 Roça 1.............................................................. 83

4.2.1.2.2 Roça 2......................................................... 87

4.2.2 Análise de correlação entre variáveis. ................................... 91

4.2.3 Análise de Componentes Principais (PCA) ............................ 92

4.2.3.1 Descarte de variáveis................................................. 106

4.3 Eletroforese de isoenzimas. ............................................................ 111

4.3.1 Interpretação genética dos zimogramas. ............................ 111

4.3.2 Relações fenéticas entre etnovariedades e indivíduos, baseados em dados de eletroforese de isoenzimas......... 118 4.3.2.1 Análise de Agrupamento.......................................... 119

4.3.2.2 Análise de Coordenadas Principais (PCO) ............ 133

4.4 Dinâmica evolutiva da mandioca em roças de agricultura tradicional qutóctone............................................................................. 140

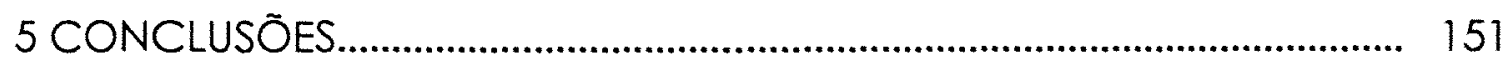

REFERÊNCIAS BIBLIOGRÁFICAS............................................................ 153

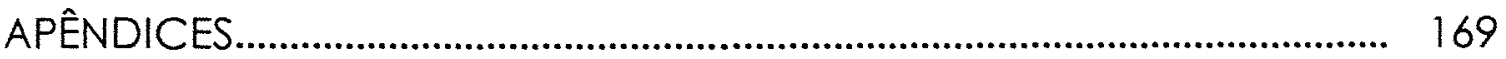


1 Localizaçāo geográfica dos locais escolhidos para o

Página

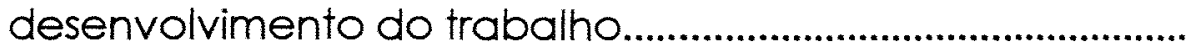

2 Comunidade de Ariri vista a partir da entrada do canal de da acesso a comunidade........................................................

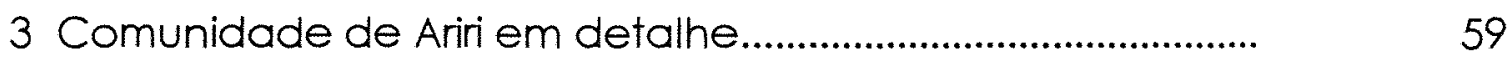

4 Roça 1, com culturas em consorciaçāo: mandioca, cará

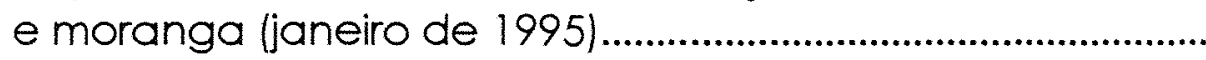

5 Roça 1. com culturas em consorciaçāo: mandioca, batata-doce e melancia (janeiro de 1995)...............................

6 Agrupamento, pelo método de UPGMA, das vinte amostras de etnovariedades de mandioca de Ariri 1 . roça 1 .

7 Agrupamento, pelo método de Ward, das vinte amostras de etnovariedades de mandioca de Ariri 1 , roça 1 ................

8 Agrupamento, pelo método de UPGMA, das 12 amostras de etnovariedades de mandioca de Ariri 1 roça 2.................

9 Agrupamento, pelo método de Ward, das 12 amostras de etnovariedades de mandioca de Ariri 1 roça 2...........

10 Agrupamento, pelo método de UPGMA, das 17 amostras de etnovariedades de mandioca de Ariri 1 roça 3.

11 Agrupamento, pelo método de Ward, das 17 amostras de etnovariedades de mandioca de Ariri 1 roça 3............ 
12 Agrupamento, pelo método de UPGMA, das 32 amostras de etnovariedades de mandioca de Arir 2 roça 1

13 Agrupamento, pelo método de Ward, das amostras de etnovariedades de mandioca de Ariri 2 roça 1

14 Agrupamento, pelo método de Ligação Simples, das amostras de etnovariedades de mandioca de Ariri 2 roça 1

15 Agrupamento, pelo método de UPGMA, das amostras de etnovariedades de mandioca de Ariri 2 roça 3.

16 Agrupamento, pelo método de Ward, das 20 amostras de etnovariedades de mandioca de Ariri 2

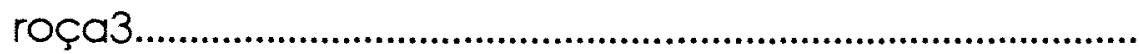

17 Escores provenientes da análise de componentes principais entre amostras de etnovariedades de mandioca de Ariri 1, roça 1, considerando os componentes 1 e 2

18 Contribuição das variáveis originais para os componentes principais 1 e 2 entre as amostras de etnovariedades de mandioca de Ariri 1, roça 1.............

19 Escores provenientes da análise de componentes principais entre amostras de etnovariedades de mandioca de Ariri 1, roça 1, considerando os componentes 1,2 e 3 
20 Escores provenientes da análise de componentes principais entre amostras de etnovariedades de mandioca de Ariri 1, roça 2, considerando os

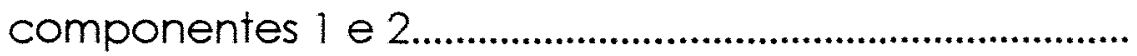

21 Contribuição das variáveis originais para os componentes principais 1 e 2 entre as amostras de etnovariedades de mandioca de Ariri 1, roça 2...............

22 Escores provenientes da análise de componentes principais entre amostras de etnovariedades de mandioca de Ariri 1, roça 3, considerando os componentes 1 e 2.................................................................

23 Contribuição das variáveis originais para os componentes principais 1 e 2 entre as amostras de etnovariedades de mandioca de Ariri 1, roça 3.

24 Escores provenientes da análise de componentes principais entre amostras de etnovariedades de mandioca de Ariri 1, roça 3, considerando os componentes 1,2 e 3

25 Escores provenientes da análise de componentes principais entre amostras de etnovariedades de mandioca de Ariri 2, roça 1, considerando componentes 1 e 2

26 Contribuição das variáveis originais para os componentes principais 1 e 2 entre as amostras de etnovariedades de mandioca de Ariri 2, roça 1.

27 Escores provenientes da análise de componentes principais entre amostras de etnovariedades de mandioca de Ariri 2, roça 1, considerando os componentes 1,2 e 3 
28 Escores provenientes da análise de componentes principais entre amostras de etnovariedades de mandioca de Ariri 2, roça 3, considerando os componentes 1 e 2 .

29 Contribuição das variáveis originais para os componentes principais 1 e 2 entre as amostras de etnovariedades de mandioca de Ariri 2 , roça 3..............

30 Escores provenientes da análise de componentes principais entre amostras de etnovariedades de mandioca de Ariri 2, roça 3, considerando os componentes 1,2 e 3

31 Escores provenientes da análise de componentes principais entre amostras de etnovariedades de mandioca de Ariri 2, roça 3, considerando os componentes 1 e 2, com o conjunto simplificado de variáveis

32 Escores provenientes da análise de componentes principais entre amostras de etnovariedades de mandioca de Ariri 2, roça 3, considerando os componentes 1, 2 e 3, com o conjunto simplificado de variáveis

33 Agrupamento, através do método de UPGMA, das amostras de etnovariedades de mandioca de Ariri2, roça 3 , com o conjunto simplificado de variáveis e utilizando a matriz de distância euclidiana média...........

34 Agrupamento, através do método de Ward, das amostras de etnovariedades de mandioca de Ariri 2 . roça 3, com o conjunto simplificado de variáveis e utilizando a matriz de distância euclidiana média 
35 Zimograma dos padrōes eletroforéticos apresentando todos os sistemas enzimáticos estudados.

36 Foto do sistema enzimático PGI, mostrando 20 indivíduos amostrados em Ariri 7

37 Foto do sistema enzimático SKDH, mostrando 20 indivíduos amostrados em Ariri 2.

38 Foto do sistema enzimático MDH, mostrando 20 indivíduos amostrados em Ariri 2

39 Foto do sistema enzimático LAP, mostrando 17 indivíduos amostrados em Ariri 1

40 Agrupamento, através do método de UPGMA, das amostras de etnovariedades de mandioca de Arir ,1 roça 1, utilizando a matriz de dissimilaridades genéticas.

41 Agrupamento, através do método de UPGMA, das amostras de etnovariedades de mandioca de Ariri 1 roça 2, utilizando a matriz de dissimilaridades genéticas.

42 Agrupamento, através do método de UPGMA, das amostras de etnovariedades de mandioca de Ariri 1 roça 3, utilizando a matriz de dissimilaridades genéticas.

43 Agrupamento, através do método de UPGMA, das amostras de etnovariedades de mandioca de Ariri 2 roça 1, utilizando a matriz de dissimilaridades genéticas. 
44 Agrupamento através do método de UPGMA, das amostras de etnovariedades de mandioca de Ariri 2. roça 2, utilizando a matriz de dissimilaridades genéticas.

45 Agrupamento, através do método de UPGMA, das amostras de etnovariedades de mandioca de Ariri 2. roça 3, utilizando a matriz de dissimilaridades genéticas.

46 Agrupamento, através do método de ligação completa, das amostras de etnovariedades de mandioca de Ariri 2, roça 3, utilizando a matriz de dissimilaridades genéticas.

47 Agrupamento, através do método de UPGMA, das amostras de etnovariedades de mandioca de Praia Grande roça 1, utilizando a matriz de dissimilaridades genéticas

48 Agrupamento, através do método de UPGMA, das amostras de etnovariedades de mandioca de Praia Grande roça 2, utilizando a matriz de dissimilaridades genéticas.

49 Agrupamento, através do método de UPGMA, das amostras de etnovariedades de mandioca de Praia Grande roça 3, utilizando a matriz de dissimilaridades genéticas.

50 Agrupamento, através do método de UPGMA, das amostras de etnovariedades de mandioca de Praia Grande roça 4, utilizando a matriz de dissimilaridades genéticas. 
51 Escores provenientes da análise de coordenadas principais, caculada a partir das similaridades genéticas de 32 amostras de etnovariedades de mandioca de Ariri 2, roça 1. Considerando as coordenadas 1 e 2..................................................................

52 Escores provenientes da análise de coordenadas principais calculada a partir das similaridades genéticas de 32 amostras de etnovariedades de mandioca de Ariri 2, roça 1. Considerando as coordenadas 1,2 e 3

53 Escores provenientes da análise de coordenadas principais calculada a partir das similaridades genéticas de 13 amostras de etnovariedades de mandioca de Ariri 2, roça 2. Considerando as coordenadas 1 e 2

54 Escores provenientes da análise de coordenadas principais calculada a partir das similaridades genéticas de 13 amostras de etnovariedades de mandioca de Ariri 2, roça 2. Considerando as coordenadas 1,2 e 3

55 Escores provenientes da análise de coordenadas principais calculada a partir das similaridades genéticas de 20 amostras de etnovariedades de mandioca de Ariri 2, roça 3. Considerando as coordenadas 1 e 2 .

56 Escores provenientes da análise de coordenadas principais calculada a partir das similaridades genéticas de 20 amostras de etnovariedades de mandioca de Ariri 2, roça 3. Considerando as coordenadas 1,2 e 3. 
57 Modelo de Dinâmica Evolutiva da Mandioca....................

58 Foto da roça recém aberta para cultivo............................

59 Foto da roça no início do cultivo, com a população de mandioca em destaque. 
1 Total de sistemas testados, e aqueles incluídos na análise para cálculo de distância

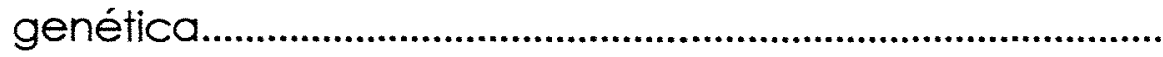

Página

2 Espécies cultivadas e número de variedades presentes nas roças de Ariril, pertencentes a uma única família de agricultores.

3 Unidades amostrais dentro das roças estudadas, no ano de 1995.

4 Frequência das amostras identificadas dentro dos quadrados amostrais, número estimado para cada etnovariedade dentro da roça, e estimativa total de indivíduos.

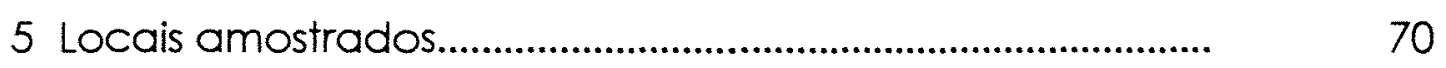

6 Variedades coletadas e sua particularidades.....................

7 Valores máximos, mínimos e médios das distâncias euclidianas obtidas nas roças estudadas.

8 Coeficientes de correlação cofenética obtidos para cada dendrograma apresentado.

9 Coeficientes de correlação obtidos para cada dendrograma apresentado.

10 Frequências fenotípicas (\%do total de presença de uma banda) de todas as bandas dos sistemas enzimáticos 
11 Coeficiente de correlação cofenético para todas as roças estudadas.......................................................................

12 Valores máximos, mínimos e médios dos índices de similaridade obtidos nas roças estudadas..............................

13 Resultados do teste de Mantel para todas as roças de Ariri.

14 Relações entre manejo tradicional e eventos de dinâmica evolutiva da mandioca............................................. 
TAXONOMIA FOLK E DIVERSIDADE INTRAESPECÍFICA DE MANDIOCA (Manihot esculenta Crantz) EM ROÇAS DE AGRICULTURA TRADICIONAL EM ÁREAS DE MATA ATLÂNTICA DO SUL DO ESTADO DE SÃO PAULO

\author{
Autor: Nivaldo Peroni \\ Orientador: Prof. Dr. Akihiko Ando
}

RESUMO

Agricultores tradicionais autóctones são responsáveis por manter etnovariedades conservadas in situ, e são responsáveis por processos dinâmicos de amplificação de variabilidade genética. A variabilidade manipulada por estes agricultores pode ser maior do que a variabilidade reconhecida e nomeada sob a forma de etnovariedades.

Através da avaliação da variabilidade de mandioca (Manihot esculenta Crantz) manejada por agricultores tradicionais autóctones do sul do litoral paulista e do Vale do Ribeira de Iguape, foram estudadas 10 roças, com os seguintes objetivos: a) Determinar a variabilidade intraespecífica de mandioca, ao nivel das etnovariedades, presente num sistema agrícola de corte e queima, através do uso de marcadores bioquímicos (isoenzimas), e de caracteres morfológicos; b) Avaliar e comparar a variabilidade reconhecida e nomeada pelo agricultor e a variabilidade intra-roça presente e não necessariamente reconhecida; c) Interpretar os padrões de variabilidade sob um modelo de dinâmica evolutiva da mandioca. 
Foram utilizadas para estes fins, 3 técnicas de amostragem em 10 roças em locais diferentes, e em ciclos agricolas diferentes: 1) coleta de amostras de etnovariedades nomeadas pelo agricultor com interferência dele na escolha de cada amostra; 2) coleta de amostras de etnovariedades nomeadas pelo agricultor sem interferência dele na escolha de cada amostra; 3) amostragem aleatória dentro da roça sem nomeação individualizada. Ao todo foram estudados 356 indivíduos, sendo avaliados 21 caracteres e sendo feitas posteriormente as seguintes análises: cálculo de distância euclidiana média entre amostras, análise de agrupamento, e análise de componentes principais (PCA). Os indivíduos foram submetidos à eletroforese de isoenzimas, sendo então utilizada presença e ausência de bandas isoenzimáticas, cálculo do índice de similaridade genética (coeficiente de semelhança simples, "Simple Matching"), análise de agrupamento e análise de coordenadas principais (PCO). As distâncias obtidas a partir de cada conjunto de dados foram comparadas através de correlação de Mantel.

A partir dos resultados, foi possivel concluir que os agricultores subestimam a variabilidade presente intra-roça, dando o mesmo nome à genótipos diferentes. Além disso foi possivel concluir que cada etnovariedade de mandioca é constituida por genótipos distintos, com grande semelhança na morfologia, compondo uma população heterogênea.

Através da interpretação dos resultados sob $\circ$ modelo de dinâmica evolutiva de mandioca, é possivel inferir sobre a origem destes 
genótipos via hibridação intraespecífica. Sendo assim, os processos sexuais existentes, amplificam a variabilidade de mandioca dentro das roças, interagindo com as técnicas de manejo empregadas secularmente. 
FOLK TAXONOMY AND INTRASPECIFIC DIVERSITY OF CASSAVA Manihot esculenta Crantz) IN TRADITIONAL AGRICULTURE GARDENS ON ATLANTIC FOREST AREAS OF SOUTHERN SÃO PAULO STATE (BRAZIL)

Author: Nivaldo Peroni Adviser: Prof. Dr. Akihiko Ando

\section{SUMMARY}

Traditional farmers can maintain folk varieties conserved in situ, also keeping dynamic processes of amplification of genetic variability. These farmers can manage a larger variability than that is recognized and named as folk varieties (ethnovarieties).

The objective of this study is to evaluate the variability of cassava (Manihot esculenta Crantz) managed by traditional farmers from Southern coast of São Paulo State and from Vale do Ribeira de Iguape. Specifically, this study intends to: a) Determine cassava's intraspecific variability (as ethnovarieties) in a slash-and-burn system through the use of biochemical markers (isozymes) and morphological characters; b) Evaluate and compare the variability recognized and named by the farmer; and c) Explain the variability patterns under a model of cassava's evolutionary dynamics.

For these purposes, three sample methods were employed in 10 gardens ("roças") in different places and under different agricultural 
cycles: 1) sample of ethnovarieties which were named one by one by the farmer with and 2) without his interference in sample choices; 3) random sample inside the plot without individualized nominations. Twenty one morphological characters were evaluated in 356 individuals. Measures of mean Euclidean distance between samples were made, as well cluster analysis, and principal component analysis (PCA). For isozyme electrophoresis were used presence and absence of isozymatic bands, and genetic similarity index (simple matching coefficient), cluster analysis and principal co-ordinates analysis (PCO). The obtained distances in each data group were compared through Mantel's correlation.

The farmers underestimate the variability intra-garden, giving equal names to different genotypes. Each cassava ethnovariety is composed by distinct genotypes with large morphological similarity, making a heterogeneous population.

Analyzing the results through a model of cassava's evolutionary dynamics, it is possible to intepret that these genotypes were originated by intraspecific hybridization. Sexual processes do amplify cassava's variability intra-plots and also interacts with the management techniques employed secularly by the farmers. 


\section{INTRODUÇÃO}

A conservação de recursos genéticos é de fundamental importância para a agricultura moderna, principalmente por ser a fonte de gens utilizáveis no melhoramento vegetal. Nos últimos 25 anos tem sido grande o esforço para a preservação de recursos genéticos em bancos de germoplasma ou ex situ (Soleri \& Smith, 1995), entretanto nestes bancos de genes os processos dinâmicos, geradores de variabilidade, não estão mais atuando, como estariam sob influência de pressōes seletivas humanas, através da utilização e conservação in situ (Brush, 1995). Os bancos internacionais de germoplasma mantendo recursos genéticos ex situ procuram conservar a máxima variabilidade genética possivel dos materiais através da maximizaçāo da reproduçāo do germoplasma. Seu objetivo, entretanto acaba sendo oposto aos objetivos de agricultores tradicionais que estão interessados na diversidade e na estrutura populacional que permitem maximizar a adaptação local (Soleri \& Smith, 1995). Estes agricultores tradicionais dominam um conjunto de técnicas específicas e complexas de cultivo transmitidas oralmente (Gomez-Pompa \& Kaus, 1987) sendo responsáveis por manter, in situ, a variabilidade genética de seus cultivos (Altieri \& Anderson, 1992; Bennet, 1992; Cleveland et al., 1994; Dufour, 1990; Eden, 1988; Oldfield \& Alcorn, 1987 e Padoch \& Jong, 1991) e ampliá-la através de processos evolutivos contínuos (Brush, 1991: Ceccarelli et al., 1992; Cury, 1993 e Salick, 1992). Portanto, a conservação in situ ganha outra 
perspectiva, que é a de ampliar a variabilidade através da manutenção de toda uma gama de processos geradores de novos variantes, sendo estes processos "congelados" nos bancos de germoplasma.

Na busca por respostas concretas sobre os processos dinâmicos atuantes in situ sob o domínio do conhecimento tradicional, a cultura da mandioca mostra-se apropriada por estar intimamente relacionada à forma tradicional de cultivo indígena presente no Brasil (Martins, 1994). Este sistema é caracterizado pela derrubada, pelo corte e queima da mata para abertura de uma roça, sendo o período de uso inferior ao período de pousio ao qual ela é submetida. Além disso, a diversidade inter e intraespecífica é elevada, e o cultivo é feito sob a forma de consórcio.

A cultura da mandioca apresenta elevada diversidade intraespecifica representada pelas etnovariedades, sendo cultivada nas roças onde sofre pressões seletivas naturais e humanas (Cury, 1993). Nestas roças, o agricultor reconhece as etnovariedades através de características morfológicas aparentes e as nomeia mantendo toda uma rede de significados e importância do ponto de vista social (Chernela, 1987). A cultura então assume, nestes sistemas, importância alimentar, social e econômica, e adquire, como recurso genético, relevância para o melhoramento de variedades comerciais.

Nestes sistemas agrícolas, há indícios de que a nomenclatura em nível intraespecífico não é tão acurada como é para o nivel interespecifico, podendo existir muito mais variabilidade intra-roça do que aquela reconhecida pelo agricultor. Este tipo de ocorrência foi encontrado nos cultivos tradicionais da cultura da batata nos Andes peruanos por Quiros et al. (1990), sendo que a elucidação deste tipo de 
problema é favorecida tanto pelas técnicas hoje disponiveis, como o uso de marcadores morfológicos e bioquímicos (Gepts, 1993 e Quiros et al., 1990), como pelas abordagens teóricas sobre domesticação (Harlan, 1992; Salick, 1992 e Salick, 1995), e etnobiologia. Esta última vem a ser essencialmente 0 estudo do conhecimento e das conceituações desenvolvidas por qualquer sociedade a respeito da biologia, na visão de Posey (1987), ou também vem a ser o campo de estudo das complexas relações de plantas e animais, do presente e do passado, com sociedades humanas, na definição de Berlin (1992). Uma visão mais detalhada de uma área específica da etnobiologia, a etnobotânica, e seu relacionamento com outras áreas do conhecimento, é destacada por Given \& Harris (1994) e por Schultes \& Reis (1995)

Estas abordagens complementares influenciam tanto as interpretações dos processos geradores de variabilidade como estratégias de coleta de germoplasma para conservação ex situ. Logo. a integraçāo de abordagens é necessária e bastante proficua no sentido de se entender como a conservação e ampliação in situ de germoplasma de mandioca é executada, e como podemos associá-la à conservaçāo ex situ.

Neste sentido, os objetivos da dissertação são os seguintes:

a) Determinar a variabilidade intraespecífica de mandioca, ao nivel das etnovariedades, presente num sistema agricola de corte e queima, através do uso de marcadores bioquímicos (isoenzimas), e caracteres morfológicos.

b) Avaliar e comparar a variabilidade reconhecida e nomeada pelo agricultor e a variabilidade presente e não necessariamente reconhecida, existente intra-roça. 
c) Interpretar os padrões de variabilidade sob o modelo de dinâmica evolutiva da mandioca.

- presente trabalho procura então contribuir para 0 entendimento da influência que certas técnicas de manejo agricola tradicional têm sobre a geração e manutenção de variabilidade genética in situ. Estas técnicas pertencem ao universo de conhecimentos das populaçōes humanas envolvidas, e a função deste trabalho não é traduzí-las mas tentar explicitá-las à luz de uma interpretaçāo sincrônica. 


\section{REVISÃO DE LITERATURA}

\section{I Agricultura tradicional}

O termo agricultura tradicional designa sistemas agricolas caracterizados pela prevalência de técnicas utilizadas por gerações contínuas de agricultores. Estas técnicas envolvem um conjunto de conhecimentos específicos e complexos do sistema de produção manejado, que é transmitido através de tradiçāo oral. Uma das características destes sistemas é a grande diversidade inter e intraespecifica de espécies cultivadas e a manutenção de processos evolutivos dinâmicos onde estão presentes: interações planta-homem. conservação de germoplasma, e conservação de seus respectivos ambientes (Alcorn, 1990 e Oldfield \& Alcorn, 1987). Segundo estes autores, muito da diversidade biológica do mundo está sob custódia de agricultores que seguem antigas técnicas e práticas de uso da terra; sendo estes sistemas agricolas ecologicamente complexos e associados com centros de diversidade genética de plantas cultivadas. Incluem não apenas cultivares tradicionalmente utilizados, mas também espécies selvagens aparentadas com as espécies cultivadas.

A complexidade ecológica de sistemas tradicionais parece surpreender aqueles acostumados aos sistemas agrícolas de zonas temperadas. A complexidade mantém alta variação genética, tanto 
temporal como espacial, seletivamente pressionadas, intergenotipicamente e interespecificamente competindo, e interagindo com pestes e patógenos. A diversidade genética é mantida pela intervenção cultural, assim como pressionada pela seleção natural, logo tanto fatores humanos como biológicos interagem sobre a espécie ou cultivar manejado, não existindo barreiras claras que separam os fatores (Alcorn, 1990). Segundo Brush (1992), a diversidade é o resultado de processos de evolução cultural e biológica que geram e mantêm diversidade através de hibridização, isolamento e seleção humana e natural. Deve ser entendida como uma condição histórica de certos sistemas agricolas, mas que é reiterada anvalmente pelos agricultores. A diversidade é intencionalmente mantida e pode ser verificada pela rica nomenclatura e classificaçāo sistemática da diversidade cultivada, por diferentes variedades plantadas em diferentes zonas de produção; pelo manejo diferenciado nas fases de cultivo, processamento e armazenamento, e pelos usos diferentes na culinária e em rituais religiosos.

É importante compreender que cada agricultor é um indivíduo diferente, que toma suas decisōes através de acerto e erro e possui uma bagagem única de informações, obtidas de outras pessoas, seja de forma oral ou escrita, que suplementa o conhecimento cultural compartilhado pela comunidade (Gomez-Pompa \& Kaus, 1987). Segundo os mesmos autores, cada conjunto de conhecimentos individuais pode ser agregado, em parte, ao conhecimento geral da comunidade, construindo assim um conjunto acumulativo de idéias e técnicas que tem resistido através do tempo. Em comunidades muito antigas, o resultado disto é uma grande variedade de técnicas que se 
constituem numa verdadeira "biblioteca" de conhecimento compartilhado. Interessa aos estudos sobre a variabilidade genética resguardada por estas comunidades, as decisões tomadas a partir desta "biblioteca", e seu efeito sobre o meio ambiente e o complexo agrícola (Gomez-Pompa \& Kaus, 1987). Estas observaçōes "diacrônicas" podem ser de grande valor e complementares às observações "sincrônicas" na qual a ciência ocidental está baseada (Gadgil et al., 1993)

- Em diferentes partes do mundo, os sistemas agrícolas tradicionais diferem em idade, estrutura e manejo, existindo uma grande variabilidade de modelos ecológicos e agronômicos básicos, que caracterizam os sistemas agrícolas tradicionais dominantes (Altieri \& Merrick, 1987). Segundo estes autores, o grau de biodiversidade depende da diversidade da vegetação dentro e ao redor do sistema agrícola; da permanência de vários cultivos dentro do sistema; da intensidade do manejo e do grau de isolamento do sistema em relação à vegetação natural.

Os sistemas agrícolas itinerantes, por apresentarem grande diversidade interespecífica e intraespecifica têm sido comparados analogamente à complexidade do ambiente onde estão inseridos, frequentemente florestas tropicais (Hames, 1983). Segundo Eden (1988), estudos detalhados da composição de cultivos, e informações em termos de diversidade são raros. O autor cita que estudos feitos na Amazônia têm indicado que a mandioca (Manihot esculenta) representa $80 \%$ ou mais das populações cultivadas e que sob tais circunstâncias, analogias com a diversidade de espécies de floresta tropical não se justificam e que as vantagens ecológicas mencionadas como análogas não são afirmáveis com segurança. Utilizando dados 
comparativos, o autor mostra que pode variar a composição e a extensão das populações cultivadas, assim como a dominância de uma espécie cultivada em particular.

\subsection{Agricultura de corte e queima, de coivara ou itinerante}

O sistema de agricultura de corte e queima, de coivara ou itinerante apresenta basicamente um período de derrubada da mata, de enleiramento e queima, e de utilização, sendo um sistema próprio da região tropical e subtropical do mundo. Kleinman et al. (1995) citam diversos trabalhos que determinam a razão de uso e de pousio. Os exemplos citados mostram razões de 1:9 (um ano de cultivo para nove anos de pousio) encontrado na Tailândia setentrional, 1:3 em alfisols no oeste africano e 5:12 até 6:15 em oxisols de alta saturação de bases. Em Lal (1985) citados por Kleinman et al. (1995), a razāo de 3:15 é suficiente para manter os solos férteis e utilizáveis ciclicamente. Na região de Cananéia, sul do estado de São Paulo, a razão se mantêm por volta de 3:15 segundo Peroni \& Martins (1995), que analisaram 6 roças distribuídas ao longo de propriedades que mantêm o sistema de corte e queima como sistema de produção agrícola.

No Brasil, o sistema remonta ao período pré-colonial, assentandose em técnicas de agricultura indígena. Na literatura, há diversos trabalhos que descrevem este sistema em diferentes culturas no mundo, como na Amazônia por Carneiro (1983), Chernela (1987) e Posey (1987). em Papúa Nova Guiné por Rappaport (1971) e Eden (1993), e em Camarões por Westphal (1981).

Estes mesmos trabalhos nos indicam que neste sistema de 
agricultura tropical, grande parte das espécies cultivadas tem como a parte alimentícia o sistema radicular, e é de propagação vegetativa (mandioca, taro ou taioba, cará, inhame, batata-doce). Estas espécies, porém, não perderam ao longo do processo de domesticação a capacidade de reprodução sexual, fazendo com que exista grande complexidade em termos de surgimento e fixação de variantes cultiváveis. Junta-se a esta caracteristica biológica aspectos culturais que se relacionam com a manutenção e ampliação destes variantes. Logo as interrelaçōes às quais estas espécies estão sujeitas fazem necessário um aprofundamento teórico, onde se considera não só a espécie em si, mas o manejo ao qual ela está submetida; implicitamente interessa saber como o homem amplia e mantém estas variantes agindo como seletor natural e como seletor consciente e inconsciente.

Neste sistema agrícola assim como em outros sistemas tradicionais, encontramos as chamadas etnovariedades.

\subsection{Diversidade intraespecífica em roças de agricultura tradicional} (etnovariedades), e taxonomia folk

Etnovariedade (folk variety) é uma designação para as já conhecidas raças locais (landraces), variedades tradicionais, ou variedades primitivas, e tem sido definida como uma população geograficamente ou ecologicamente distinta a qual diverge em sua composição tanto entre populações como dentro delas (Brown, 1978): porém o que a diferencia é ser produto de seleção local por agricultores tradicionais Harlan (1992) citado por Cleveland et al. (1994). Muitas espécies sāo utilizadas tradicionalmente para fins diversos, como para 
uso medicinal, religioso, para manufaturas, e sāo designadas por etnoespécie.

As etnovariedades representam recursos genéticos agricolas que vêm sendo coletados e utilizados pelos centros de germoplasma e conservados de forma ex situ. Segundo Soleri \& Smith (1995), as consequências e objetivos da conservaçāo ex situ se diferenciam dos da conservação in situ efetuada por agricultores tradicionais. Segundo estes autores, os melhoristas formais se preocupam em manter a máxima diversidade genética armazenada nos bancos de germoplasma enquanto que os agricultores estão preocupados com a diversidade $e$ com a estrutura populacional que garantam maior adaptação locai.

Segundo Brush et al. (1981), a invenção e desenvolvimento da agricultura criou uma diversidade tremenda entre as espécies selecionadas pelo homem e esta diversidade ainda é evidente em áreas originais de domesticação, sendo mantida como variedades ancestrais ou variedades locais pelos agricultores tradicionais. Estes autores elaboraram um modelo dos principais fatores biológicos e humanos que interagem afetando seleção, manutenção e distribuição de germoplasma de batata (Solanum spp) nos Andes pervanos. Concluíram que a manutenção das etnovariedades não é aleatória, que o sistema de cultivo é acompanhado de uma nomenclatura regular, e de taxonomia local organizada, e que a seleção de variedades ocorre em função de caracteristicas culinárias, sendo que a adaptabilidade biológica é reconhecida para certos clones.

A simples mensuração do número de etnovariedades ou a relação de nomes é criticada por Cleveland et al. (1994). Segundo estes autores, muitos estudos usam o número de variedades nomeadas para 
representar diversidade genética, entretanto não é válido assumir que nomes varietais são ideais para distinguir composição genética, eles apenas refletem diferenças fenotípicas do nivel populacional, as quais devem ser resultados de diferenças genéticas significativas. Os autores citam o trabalho desenvolvido por Quiros et al. (1990) para dar base à critica. Este trabalho, utilizando marcadores isoenzimáticos em batata peruana, mostra que apesar de existir grande congruência entre o sistema de classificação usado pelos agricultores, para denominar suas variedades, e os fenótipos eletroforéticos, os nomes varietais podem não representar diferenças genéticas e vice-versa. Este resultado também foi encontrado por Cury (1993) trabalhando com mandioca e fazendo diferenciaçōes através de técnicas biométricas. Cleveland et al. (1994) enfatizam a necessidade da distinçāo genética das variedades nomeadas pelos agricultores, especialmente para espécies alógamas.

Algumas questōes básicas são colocadas por Quiros et al. (1990) no contexto da diversidade genética encontrada em batata cultivada nos Andes pervanos, sendo que estas questões e hipóteses esta revisão corrobora.

Estes autores apresentam as seguintes questões: a) por que existe tanta diversidade intraespecífica em espécies cultivadas e por que é tão exagerada em certas regiōes? b) qual a contribuição de fatores ecológicos, agronômicos e humanos para originar e manter esta diversidade? c) qual é o melhor caminho para descrever e analisar esta diversidade? d) como esta diversidade é afetada por mudanças agrícolas, econômicas entre outras?

Longe de responder a todas estas questões, as quais nos guiam em termos teóricos, os autores indicam dois passos primários para 
respondê-las. Deve-se entender a base genética da espécie cultivada e descrever os caminhos pelos quais os agricuitores percebem e selecionam os cultivares, assim como afetam a diversidade. Segundo Brush (1986), para investigar como e por quê os agricultores em centros de domesticação mantêm diversidade, deve-se iniciar com a explicitação da taxonomia folk e sua relação com a base genética dos cultivos.

Na literatura é encontrada ampla discussão sobre as bases da classificação etnobiológica, ou da taxonomia folk (Berlin, 1992; Berlin et al., 1973 e Hunn, 1982) onde fatores utilitários e cognitivos na diferenciação e classificação de organismos por populações autóctones poderiam ser mutuamente exclusivos ou agir em conjunto (Clemente, 1995). A "visāo utilitária" tem por trás a pergunta: Como e quais os caminhos que as sociedades humanas encontraram para "usar a natureza"? e a "visão cognitiva" tenta responder: Como e quais os caminhos que as sociedades encontraram para "ver a natureza"? (Berlin, 1992).

Segundo Berlin (1992), antes do homem começar a utilizar os recursos biológicos de um ambiente, ele deve primeiro classificá-los. Para este autor, as pessoas devem ser capazes de reconhecer, categorizar e identificar exemplares de uma espécie, ou um grupo de espécies similares, diferenciando de outras, e devem ser capazes de transmitir este conhecimento. Entretanto ele ressalta que o homem não cria categorias ou ordens mas apenas tenta discerni-las, organizando-as em categorias culturais que podem ter correspondência biológica.

Para Berlin (1992), deve-se reconhecer o valor da "visão utilitária" $e$ da "visão cognitiva" nos estudos de classificação etnobiológicos e 
apesar de existir o debate sobre quai visão predomina, o desafio fundamental é responder: Por que as sociedades humanas classificam a natureza da forma que é feito?

Quando se trabalha com niveis muito contínuos de variação, como os intraespecíficos, observa-se, em estudos etnotaxonômicos, que quanto mais extensa a subcategorização, mais significativa a espécie é do ponto de vista utilitário (Posey, 1987), sendo que a politipia aumenta diretamente com a intensidade de manejo humano da espécie (Berlin, 1992). Para Hunn (1982), existem fatores utilitários, diretamente relacionados à importância econômica na classificação dos seres vivos, e aqueles com maior valor utilitário tendem a ser melhor identificados através de um detalhamento maior, fato este também discutido por Brush (1992).

Para Quiros e sua equipe, a nomenclatura folk e/ou taxonomia folk criam marcadores e chaves para distinguir diferenças morfológicas, sendo que para a taxonomia folk as designações são elaboradas mais por razōes culturais que agronômicas e, portanto, deve-se considerar a utilidade da taxonomia para entender a dinâmica biológica de um cultivo (Boster, 1984). Os autores questionam entretanto se a taxonomia folk é tão acurada ao nível intraespecífico como é para o nivel interespecífico, e se a identificação e a classificação folk fornecem guias seguros para a estimativa de diversidade genética. $\bigcirc$ caminho encontrado pelos autores foi usar marcadores bioquímicos e correlacionar a diversidade encontrada com a diversidade apresentada através da identificação pelos agricultores. Então duas conclusōes foram básicas: a) a classificação e identificação são chaves para entender os padrões comportamentais que afetam a evolução de 
plantas, e b) os marcadores bioquímicos, especialmente isoenzimas, fornecem ferramentas efetivas para descrever a grande diversidade encontrada para as etnovariedades.

2.4 O papel das etnovariedades para a agricultura moderna, para os estudos evolutivos e para as comunidades tradicionais de agricultores

Estudos adicionais são necessários em áreas diversas em termos de recursos genéticos, sendo que adicionalmente à conservação ex situ executada por centros mundiais de conservação de germoplasma. Ceccarelli et al. (1992), sugerem: a) a exploração de conjuntos gênicos primários e secundários das culturas de maior importância usando uma abordagem agroecológica, b) estudos genéticos sobre evolução de cultivos, incluindo a razão de fluxo gênico entre os cultivos e seus parentes selvagens, c) estudos sobre a relevância e aplicabilidade de técnicas dinâmicas em manutenção genética, referindo-se à conservação in situ em áreas protegidas e "evolution gardens", e d) estudos sobre os métodos e técnicas mais adequadas para manter e usar os recursos genéticos disponíveis, como por exemplo mobilização de germoplasma, teste de multi locação e rejuvenecimento, enriquecimento de germoplasma incluindo melhoramento, e aplicação de biotecnologia.

Segundo Cleveland et al. (1994), existem pontos de vista contrastantes quanto à utilidade das chamadas variedades tradicionais, ou etnovariedades. Há claramente 0 interesse em enfatizar que as variedades modernas seriam superiores às etnovariedades nas mais 
diversas condições ambientais, salientando porém que estas etnovariedades são úteis para o futuro do melhoramento genético de espécies modernas, e serviriam como um estoque de variabilidade ou como matéria-prima para variedades industriais. Acredita-se que a conservação ex situ, através de bancos de germoplasma, seria o caminho ideal para se ter disponivel diversidade genética para a agricultura moderna. Além disso, estas variedades tradicionais poderiam ser conservadas in situ servindo como um complemento para a conservação ex situ. O outro ponto de vista, segundo os autores, enfatiza que existem evidências de que agricultores tradicionais frequentemente mantêm suas variedades antigas mesmo tendo à disposição variedades modernas, em função de características ecológicas, sociais e econômicas muito próprias. É dito que o valor potencial de etnovariedades para $\circ$ desenvolvimento de uma agricultura sustentável não estaria apenas na decodificação de informação contida no DNA destas etnovariedades, mas no fato de existir todo um conhecimento sobre sua seleção, propagação, coleta de sementes (armazenamento), crescimento, valores cuiturais, e usos. Segundo estes mesmos autores, os estudos realmente científicos a respeito destas variedades ainda são pequenos. Estratégias reais para a conservação in situ ainda são escassas, e é destacada a necessidade de se entender quais processos dinâmicos estão atuando nestas comunidades tradicionais que indicariam caminhos para a elaboração de princípios norteadores de políticas científicas de conservação biológica (Dorp et al., 1993).

Muitas das etnovariedades estão sendo cultivadas paralelamente às variedades comerciais exigentes em tecnologia moderna como o uso 
de insumos. Brush (1995) mostra que, nos cultivos de batata (Solanum spp) nos Andes peruanos, milho (Zea mays L.) no México meridional, e trigo (Triticum spp.) no leste da Turquia, o uso de alta tecnologia não tem excluido a utilização de raças locais pelos agricultores e que os casos estudados sugerem que a conservação destas raças locais pode ser independente de práticas tradicionais exclusivas. Fatores que promovem a conservação in situ destas variedades tradicionais, apesar da disponibilidade de variedades comerciais melhoradas, seriam: a fragmentação da posse da terra; condiçōes agrícolas marginais associadas com terrenos montanhosos e heterogeneidade de solos; isolamento econômico; valores culturais; e preferências por diversidade. Segundo o autor, o crescimento populacional e a integração espacial de sistemas de produção são fatores modernos que ameaçam os processos de evolução de plantas cultivadas, e o impacto destes fatores sobre a diversidade genética e sobre os processos evolucionários nāo são bem conhecidos. O uso de variedades tradicionais também é relatado em regiões com alta disponibilidade de tecnologia moderna. como em Dias (1994) com repolho e couve em Portugal, Escribano (1994) com feijāo comum na Espanha, Zeven (1993) com feijão (Phaseolus coccineus) na Hungria, e Amurrio (1993) com Pisum sativum na Península Ibérica.

Análises comparativas entre características morfológicas e de desenvolvimento de variedades melhoradas e variedades locais de alfafa (Hordeum vulgare), feitas por Ceccarelli (1991), mostram que as diferenças que as etnovariedades apresentam, parecem apontar para a existência de um complexo adaptativo, onde várias características agem conjuntamente para favorecer a sobrevivência e a reprodução. 
Segundo o autor, não existe um genótipo individual apresentando uma característica associada a uma performance superior específica, isto é, não existe o genótipo superior, e sim existem efeitos combinados de seleção natural e artificial que têm levado a uma arquitetura de genótipos representando diferentes combinações de características. Sua argumentação está relacionada ao questionamento de melhorar variedades com fim à ampla adaptaçāo a ambientes diferentes, e mostra que o conceito de melhorar um cultivar para uma grande amplitude de ambientes, na verdade leva mais em conta uma amplitude geográfica do que propriamente ambiental, e que seria muito mais racional melhorar cultivares para se manterem ao longo do tempo e não do espaço. Os agricultores estão interessados em variedades que mostrem constância de performance, que estejam adaptadas à suas condições e que tenham alto grau de estabilidade ao longo do tempo. Segundo o mesmo autor, substituir os cultivares antigos, cultivados pelos agricultores há anos, não é uma solução recomendável ou sustentável, para resolver o problema de manutenção de diversidade genética.

\subsection{A espécie Manihot esculenta Crantz}

A mandioca pertence a classe Dicotiledoneae, subclasse Archichlamydeae, ordem Euphorbiales, familia Euphorbiaceae, tribo Manihoteae, gênero Manihot e espécie Manihot esculenta Crantz (Hershey \& Amaya, 1984). A última revisão do gênero mostra 98 espécies divididas em dezenove seções (Rogers \& Appan, 1973) nativas do continente americano e distribuindo-se do extremo sul dos E.U.A. até o 
norte da Argentina. Apesar desta ampla distribuição geográfica, as espécies do gênero são mais abundantes em ecossistemas secos. Quando presentes em ambientes florestais são encontradas tanto em clareiras naturais com artificiais, sendo então consideradas espécies heliófilas e invasoras (Rogers \& Appan, 1973).

A origem e domesticação da espécie Manihot esculenta não são claramente conhecidos e hipóteses sobre múltiplos centros de origem e domesticação não são descartadas. Dois autores sintetizam as duas correntes básicas a respeito da origem do cultivar. Segundo Rogers \& Appan (1973), a espécie é apenas encontrada na forma domesticada e os parentes selvagens mais prováveis seriam $M$. aescutifolia, $M$. pringieie M. rabricaulis, todas nativas da América Central e México. Entretanto Allem (1994) considera que a espécie cultivada, e outras espécies consideradas selvagens, na verdade fazem parte da mesma espécie botânica. Para este autor, haveriam então três subespécies: $M$. esculenta subsp esculenta, compreendendo a forma cultivada, $M$. esculenta subsp peruviana e $M$. esculenta subsp flabellifolia como formas selvagens. Apesar destas controvérsias, é inegável a relação da espécie Manihot esculenta com os povos indigenas americanos que foram responsáveis pela domesticação e pela distribuição da espécie por todo o continente (Brücher, 1992; Kerr, 1987; Nassar, 1978; Ney, 1990; Saver, 1952 e Schmidt, 1958).

O trabalho de Graner (1935) é considerado pioneiro no estudo citológico de mandioca. Nele, o autor observou mais de duzentas metáfases somáticas de 37 variedades de mandioca, onde constatou 36 cromossomos em todas elas. Estudos posteriores abrangeram apenas 
20 das 98 espécies do gênero Manihot, entretanto todas as espécies estudadas apresentaram 36 cromossomos, não sendo observadas barreiras extremas de cruzamento.

Nassar (1978) estudou o comportamento cromossômico durante a meiose em sete espécies do gênero, não encontrando nenhuma meiose irreguiar, sendo que todas apresentaram número haplóide $n=18$ cromossomos. Entretanto Silva Jardim (1984) não obteve hibridos férteis quando submeteu a cruzamento as espécies $M$. glaziovii, $M$. pseudogiaziovii, M. caerulescens e $M$. pohiii, com cultivares de $M$. esculenta. Carvalho (1995), fez cruzamentos entre $M$. esculenta e $M$. psevdoglaziovii com a finalidade de estudar esterilidade. Em híbridos de primeira geração, observou a formação de univalentes, cromossomos retardatários na anáfase I e tétrades com micronúcleos. O autor indica que para restaurar a fertilidade poderia ser usado pólen não reduzido (2n). Outros estudos mostram que cruzamentos dentro do gênero são possiveis e viáveis (Lefèvre \& Charrier, 1993).

A mandioca é considerada preferencialmente exogâmica devido do seu comportamento genético, e que apresenta alta heterozigosidade e forte depressão, quando submetida à endogamia (Kawano et al., 1978). Estes autores demostram que através de autofecundação pode haver perda do vigor médio de até $54 \%$ para o caráter produção de raízes. Além disso, outros fatores favorecem a exogamia como: monoicia com dicogamia protogínica, macho esterilidade e polinização por insetos (Hershey \& Ámaya, 1984).

Estudos relacionados ao levantamento de etnovariedades cultivadas em roças indigenas, mostram a grande diversidade intraespecífica existente em mandioca e a estreita relação desta planta 
com os povos que a manejam.

Kerr (1987) encontrou até 40 variedades de mandioca e macaxeira entre os indios Desâna, sendo que 16 eram mandiocas amarelas, 23 brancas e 1 variedade de macaxeira branca. Segundo Chernela (1987), analisando 7 tribos indígenas, a média encontrada foi de 22 cultivares por tribo, e Boster (1983) encontrou, entre os índios Aguaruna e Uambisa, no Peru, 100 cultivares distintos. Estes exemplos de diversidade intraespecifica, refletem a diversidade no que se refere ao reconhecimento de variedades locais e da nomenclatura indigena. Comparaçōes genéticas da diversidade de etnovariedades, através de eletroforese de isoenzimas, podem ser encontradas em Faraldo (1995).

No contexto desta revisão, o maior destaque para a diversidade intraespecífica de mandioca relaciona-se ao modelo de dinâmica evolutiva da espécie, que vem sendo proposto e constantemente reformulado pelos estudos desenvolvidos no Laboratório de Genética Ecológica do Depto. de Genética da Escola Superior de Agricultura "Luiz de Queiroz", e originalmente articulado pelo Prof. Dr. Paulo Sodero Martins (in memoriam) . Estes estudos procuram explicitar os processos de domesticação e dinâmica evolutiva de mandioca, utilizando-a como modelo para as espécies perenes e de propagação vegetativa, e das quais a parte utilizada pelo homem são as raízes ou tubérculos (Martins, 1994). A manutenção, e sobretudo, a geração de diversidade, tem sido evidenciada pelos estudos desenvolvidos neste laboratório, e a ocorrência de fatores evolutivos que explicitam a grande variabilidade existente em mandioca, seriam: mutação, hibridação introgressiva, migração, seleção natural, perceptiva e consciente (Cury, 1993). Modelos de dinâmica evolutiva tentam explicitar como os processos de 
manejo humano interrelacionam-se com os componentes de história vital das espécies cultivadas (Harian, 1992 e Martins, 1994), numa abordagem que integra processos de coevolução homem-planta cultivada (Salick, 1995). Entretanto, poucas espécies tropicais estão sendo estudadas sob esta perspectiva, destacando-se além da mandioca, batata (Solanum tuberosum) nos Andes peruanos por Brush, (1981), Zea diploperennis por Benz et al. (1990). Cocona (Solanum sessiflorum) por Salick (1992), e melancia (Citrullus lanatus) por Romão (1995).

\subsection{Documentos históricos}

Em uma breve análise de documentos produzidos por pesquisadores dos séculos XVI, XVII e XVIII, podem ser encontrados relatos que refletem a agricultura indígena e portanto parte do passado histórico da agricultura tradicional presente no litoral sul paulista e vale do Rio Ribeira de Iguape.

No decorrer do processo de colonização do pais, a agricultura tradicional adquire um caráter "miscigenado", isto é, ela é primordialmente originada das técnicas indígenas, e das espécies nativas aqui cultivadas, mas também é influenciada pela introdução de espécies tropicais vindas das múltiplas formas de tráfego que caracterizam a expansão humana. Exemplo disso são os navios negreiros que tiveram grande influência na introduçāo de espécies vegetais africanas adaptadas às condições semelhantes de clima e cultivo (Dean, 1992). Espécies da familia Cucurbitaceae, como as melancias e os pepinos (Romão, 1995), são exemplos de introduções que foram 
adaptadas às condiçōes de cultivo local e mantidas por razōes diversas, como toda uma variedade de preferências culinárias. Apesar da extensa rede de influências, no que se refere ao caráter técnico ou de manejo, a agricultura tradicional no Brasil, como praticada em ambientes florestais, tem pouca influência da agricultura européia, seja ela portuguesa ou holandesa.

Neste contexto histórico, é importante citar que autores como Hans Staden (1942), Piso (1948), Marcgrave (1942) e Spix \& Martius (1981), concentram-se numa descrição pormenorizada das espécies manejadas pelos povos locais. Entre estes autores, Hans Staden se diferencia pelo fato de descrever o processo agrícola existente na época do descobrimento, com grande precisão de detalhes':

Descrição da abertura da roça.

"nos logares onde querem plantar, cortam primeiramente as árvores e deixam-nas seccar durante um a tres mezes. em seguida deitam fogo á derrubada e nas cinzas, entre os troncos meo carbonisados, plantam as raizes de que precisam e que chamam mandioca. Esta planta é uma arvoresinha de uma braça de altura e que produz tres raizes. Quando querem comer estas, arrancam o arbusto, quebram as raizes e collocam, em seguida, as ramas novamente no solo no fim de seis meses já as plantas que dali brotam, fornecem outras raizes para se comer. De tres modos preparam elles estas raizes. Elles as ralam numas pedrinhas fixadas sobre pranchas, até ficarem reduzidas a grãos finissimos, destes refiram então o succo, por meio do Tipiti, que é um

\footnotetext{
1 Passagem copiada textualmente a partir de HOEHNE (1937), página 77.
} 
canudo feito de lascas de paimeira, o qual esticam. Extrahido o succo passam a farinha numa peneira e fazem della bôlos chatos assados no braseiro. Os vasos em que seccam e cozinham a farinha são feitos de barro queimado e teem a forma de uma bacia chata muito grande. Elles tomam tambem as mesmas raizes e deitam-nas na agua, e as abandonam na mesma até ficarem podres. Então retiram-nas e as colocam no fumeiro para seccarem bem. Seccas assim denominam-nas Keinrima que conservam por muito tempo. Quando precisam dellas soccam-nas em um pilão de madeira e obteem uma farinha bem alva como trigo. Desta fazem bolinhos que denominam: Byyw (Beijú). E, por uitimo usam ainda a mesma mandioca assim apodrecida antes de seccar e misturam-na com a farinha secca ou verde feita pelo primeiro processo. Seccando então as misturas obteem um producto que pode ser conservado durante muito tempo e mesmo um anno, sempre bom pra comer. Esta ultima farinha é a que denominam farinha de guerra, isto é, Vithan, que é farinha dura"

O que se pretende destacar com esta descrição é a dimensão atemporal da técnica de agricultura itinerante ou de coivara. Além de representar a técnica utilizada na época, observa-se a manutenção de uma estratégia adaptativa que permanece até os dias atuais. $O$ que poderia ser denominado de "atraso" pode ser entendido como a melhor estratégia agrícola para o ambiente em questão. A descrição acima citada foi publicada por Hans Staden em 1556, e apesar de diferenças em relação ao uso da farinha e do Tipiti, como objeto para separar a água da massa ralada, todos os passos da técnica são idênticos aos passos utilizados atualmente. Se existe um legado racial no 
cabocio e no caiçara paulista, formado a partir da miscigenaçāo do índio, com o português e com o preto (Candido, 1977) existe também o legado do conhecimento agrícola herdado. Este é transmitido oralmente e associado a fatores diversos como: o conhecimento das espécies em si e a manipulação da diversidade através do cultivo, o uso para preferências culinárias e de produção, e as relaçōes humanas, sejam de parentesco ou não, entre os agricultores.

Neste contexto, sempre se destaca a utilização da mandioca como a espécie predominante, e que mereceu descriçōes mais detainadas.

Se nos voltarmos exclusivamente para as citaçōes da espécie "mandioca", vamos nos deparar com informações botânicas e de uso da espécie pelos indígenas da época². Neste ponto nos deparamos com algumas descrições que merecem destaque.

...."Há várias espécies dêste arbusto, a que os indios chamam Maniiba e Manduba; embora pareça ao primeiro aspecto não se differençarem entre si, contudo os agricultores experimentados as distinguem pela qualidade, pelo caule e pela côr, e thes dão nomes diversos, cujos principais são os seguintes. A primeira espécie se chama Mandiïbabuara; a segunda, Maniibparati, de raizes e troncos brancacentos: a terceira, Mandiibucu; a quarta, Mandiibumana, a quinta, Aipi; a sexta Tapecima; a sétima, Arpipoca; a oitava, Mandijupeba; a nona, Macaxera. Estas sete últimas têem raizes e cavies avermelhados e lactecentes. "....

Piso (1948)

2 Ou sivícolas, ou brutos, na visão do pesquisador quinhentista. 
Marcgrave (1942), por sua vez, destaca a separação existente entre as mandiocas tóxicas $e$ as não tóxicas: ....."Mandïbucu, Mandiibimana, Mandiibibijana, Mandiibiurucu, Mandiibtinga, Mandïbmaracana, Mandilibcuguacu, Apitiuba, Aipi (Aipi, se divide em outras "espécies" como ele as denominal:: Aipi guacu. Aipi arendi. Apicaba, Aipiguapamba, Aipi Jaborandi, Aipi jurumu, Aipi jurumirim, Aipi jurucuja, Aipi macaxera, Aipi maniacau, Aipi poca. Aipitajapoja, e Aipipitinga"....

Um aspecto fundamental nesta descrição é a manutenção até os dias atuais de uma mesma sistemática de classificação e sua propagação através dos anos somente por tradição oral. A designação "aipi" para mandiocas "mansas" é muito bem exemplificada nestas variedades e destaca a classificação utilizada para separar estes dois grupos.

A riqueza das informaçōes com que nos deparamos hoje nas roças estudadas, é reflexo de 500 anos de manejo hábil, e de pequenos ajustes adaptativos que continuam dinâmicos. Portanto, quando nos referimos a uma agricultura tradicional ainda existente no litoral sul paulista e Vale do Rio Ribeira de Iguape, ela na verdade reflete uma agricultura tropical indígena e transcende uma mera especificidade local. 


\section{MATERIAL E MÉTODOS}

3.1 Reconhecimento dos locais de estudo

Entre os anos de 95 e 96 foram feitas algumas viagens a campo na região da Vale do Rio Ribeira de Iguape e iitoral do Estado de São Paulo, para reconhecer e identificar locais que mantivessem sistemas agrícolas de base familiar ou comunitária, e que ainda se utilizassem de técnicas localmente tradicionais. Além da representatividade do local quanto às técnicas tradicionais, a facilidade de acesso e a disponibilidade dos agricultores no auxíio ao trabalho, foram tomados como critérios de escolha.

Os locais escolhidos foram: Comunidade Ariri em Cananéia-SP e Comunidade de Praia Grande em Iporanga-SP (Figura 1). 


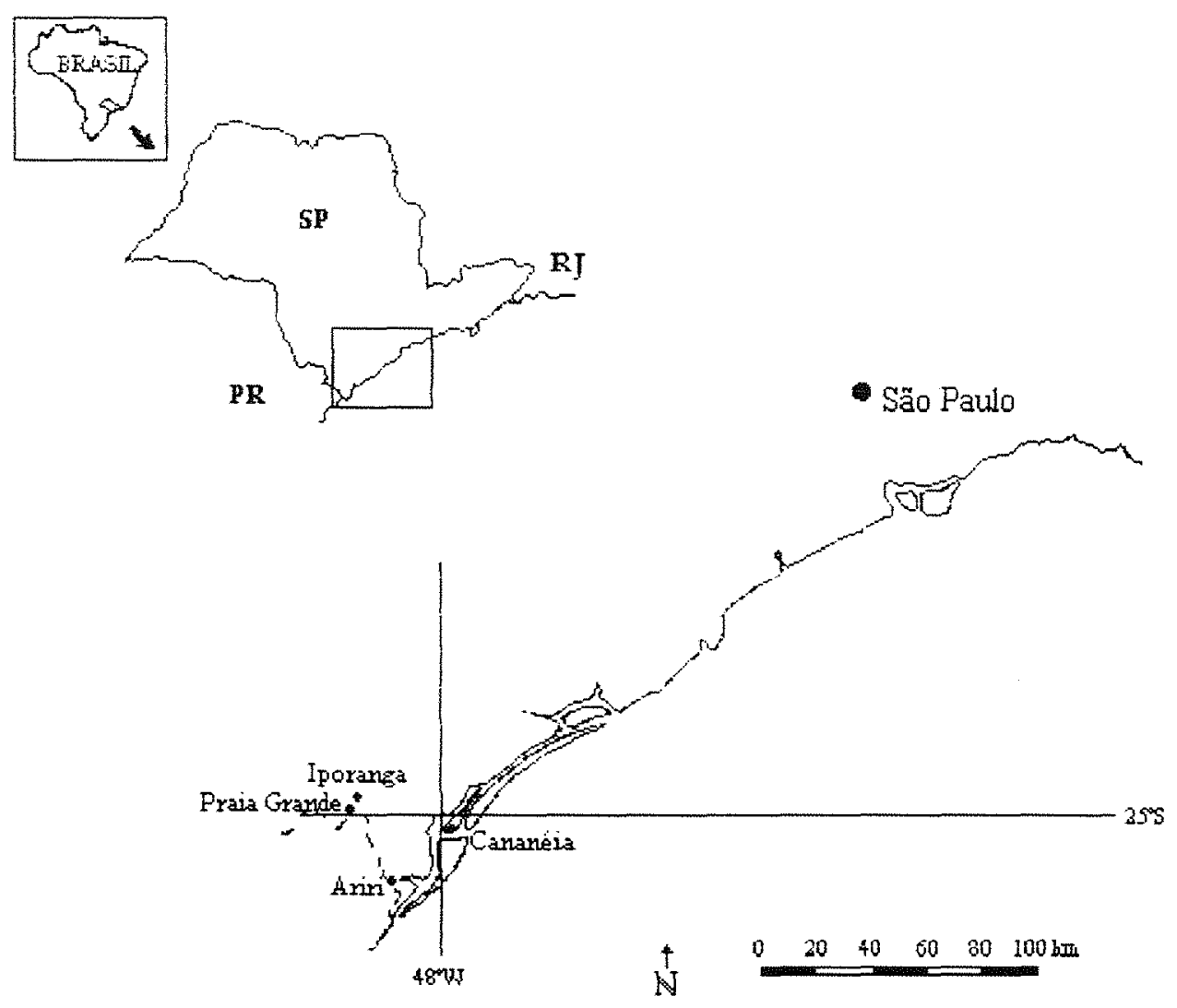

Figura 1. Localização geográfica dos locais escolhidos para o desenvolvimento do trabalho.

Os critérios utilizados na escolha do(s) informante(s) foram:

a) Familiar: A hipótese do trabalho, baseia-se na premissa de que a unidade geradora de variabilidade é a família, que utiliza a roça para atividade agrícola.

b) Idade: Este critério baseia-se na experiência com as etnovariedades cultivadas localmente e com o manejo agricola. Assim, foi escolhida a pessoa mais velha da família para fornecer as informações a respeito do processo agrícola como um todo. Adicionalmente, características locais 
e particulares de cada família foram observadas. Devido à dificuldade de acesso às roças, em alguns casos, as coletas foram acompanhadas por algum membro mais jovem da família e o membro mais velho era quem dava as informações. É importante observar que as informações de todos os membros da família são complementares e não exclusivas.

c) Sexo: Neste caso respeitou-se as "hierarquias" locais, porém não houve restrições quanto ao sexo. Muitas informações foram obtidas entrevistando-se tanto homens como mulheres, complementarmente. Entretanto, indicações prévias mostraram que as atividades eram predominantemente masculinas, e que os homens conheciam mais sobre os processos de cultivo, preparo das roças, e identificação das etnovariedades.

\subsection{Coleta de germopiasma.}

\subsubsection{Comunidade de Ariri}

A comunidade de Ariri está localizada a $60 \mathrm{~km}$ da cidade de Cananéia (litoral sul paulista). Nesta comunidade foi escolhida uma familia entre as mais antigas no local, e que utiliza do sistema itinerante como técnica agricola. Foram feitas três viagens para o local:

1) Em janeiro de 1995, quando foi feito o reconhecimento do local para desenvolvimento do trabalho. Na ocasião, foi definida a familia na qual seriam feitas as coletas de material e dados. 
2) Em junho de 1995 as amostras foram coletadas, bem como dados complementares foram obtidos.

Foi utilizada amostragem aleatória dentro das roças designadas por roça 1 , roça 2 e roça 3 , mantendo-se proporcionalidade com as variedades nomeadas, isto é, se o agricultor relatava a ocorrência de 3 variedades de mandioca plantadas na roça, eram coletadas 30 amostradas aleatoriamente. Portanto foram coletadas 30 amostras na roça 1, 20 na roça 2 e 30 na roça 3 , sem qualquer identificação e nomeação de cada amostra.

O objetivo desta coleta foi o de testar a correspondência entre os agrupamentos estabelecidos pelo agricultor, e os agrupamentos obtidos pelas análises multivariada de caracteres morfológicos e isoenzimáticos. A hipótese original seria que o número de grupos identificados seria igual ao número de agrupamentos obtidos.

Dados complementares de demografia e do sistema agrícola foram tomados.

Para demografia foram utilizados quadrados de $5 \mathrm{~m} \times 5 \mathrm{~m}\left(25 \mathrm{~m}^{2}\right)$ distribuídos ao acaso ao longo das roças. Em cada quadrado o agricultor identificava cada indivíduo de mandioca, porém estes nāo eram amostrados para posterior análise. O objetivo foi auferir o número de grupos identificados pelo agricultor em cada roça e obter estimativas de densidade e distribuição espacial, e foram usados quadradros em função da distribuição aleatória das diferentes etnovariedades dentro da roça. A informação, da distribuição aleatória das etnovariedades, auxiliou também as coletas de indivíduos ao acaso. 
As entrevistas com o agricultor informante, para caracterização do sistema agrícola, foram semi-estruturadas, isto é, foi utilizado um roteiro de questões pré-estabelecidas que eram complementadas e reelaboradas na medida da obtenção das informações (Apêndice 1).

3) Em fevereiro de 1997 foi executada a segunda amostragem no local, utilizando metodologia diferente da executada em 1995.

Foi utilizada amostragem aleatória com identificação pelo agricultor de cada individuo amostrado. A roça 3 na ocasião, não estava sendo utilizada e foi substituída por outra roça recém aberta para cultivo, e a roça 1 localizava-se adjacente a roça 1 de 1995. A roça 2 era exatamente a mesma roça amostrada um ano e meio antes. Como a colheita de mandioca é efefuada no local até um ano e meio após o plantio, a população amostrada em 1997 é resultante das populações reproduzidas das roças de 1995. É importante frisar, que as variedades de mandioca deste ano foram plantadas no periodo de agosto/setembro do ano de 1996, e que o agricultor que acompanhou a coleta na ocasião não foi o mesmo do ano de 1995. Foram coletadas 32 amostras na roça 1, 17 na roça 2 e 21 na roça 3 , em menor proporção que em 1995 pois levou-se em conta as informaçōes do agricultor quanto a proporcionalidade das etnovariedades plantadas.

No caso desta segunda amostragem, os indivíduos escolhidos ao acaso eram marcados na roça, nomeados pelo agricultor e caracterizados morfologicamente por 21 caracteres (ítem 3.3). Então obtinha-se as manivas, as quais eram identificadas por etiquetas para plantio posterior em canteiros, para execução das análises de 
eletroforese de isoenzimas.

Dados de demografia não foram obtidos neste ano, sendo que os dados quanto à caracterização do sistema foram refinados.

O objetivo desta estratégia de amostragem foi o de conferir a acurácia do agricultor na discriminação de cada indivíduo selecionado quanto a identidade genotípica, expressa nos níveis morfológico e enzimático. A hipótese original é que cada indivíduo identificado com um nome varietal seria igual a um segundo indivíduo identificado com o mesmo nome, já que a propagação vegetativa é a forma de reprodução utilizada pelo agricultor para a mandioca.

\subsubsection{Comunidade de Praia Grande}

A comunidade de Praia Grande é acessivel através de barco pelo Rio Ribeira de Iguape, a uma hora a jusante da cidade de Iporanga, no Vale do Rio Ribeira de Iguape.

Foi feita uma viagem em fevereiro de 1996, onde foram executados o reconhecimento e coleta do material.

Nesta comunidade foram feitas coletas em 4 roças distintas, pertencentes a três agricultores diferentes, denominadas roça 1 , roça 2 , roça 3 e roça 4. Nas roças desta comunidade foram executadas amostragens dirigidas pelo agricultor, isto é, era ele quem escolhia os indivíduos de uma determinada variedade e os nomeava. A partir de cada individuo nomeado recolhia-se uma maniva, que era numerada e acondicionada em um saco contendo todas as amostras daquela variedade. Neste caso, como era o agricultor que decidia quais individuos eram pertencentes à mesma variedade, julgou-se apropriado 
aumentar o número de amostras colhidas. Portanto foram coletadas manivas de 90 indivíduos na roça 1, 50 na roça 2,100 na roça 3 e 100 na roça 4, variando em funçāo do tamanho da roça.

Neste local, as roças localizavam-se em terrenos altamente declivosos, logo os dados de demografia limitaram-se a contagem dos indivíduos dentro das quadrados amostrais de $5 \mathrm{~m} \times 5 \mathrm{~m}$ (25 m=), possibilitando estimativas de densidade. As entrevistas nestas roças também foram limitadas.

\subsection{Ensaios de campo para a avaliaçāo morfológica e para eletroforese de isoenzimas.}

1) Amostras coletadas ao acaso sem identificação pelo agricultor no ano de 1995 em Ariri.

No caso i dispunha-se de estacas com aproximadamente $50 \mathrm{~cm}$ de comprimento de cada indivíduo amostrado, portanto aproveitou-se apenas duas manivas, de $20 \mathrm{~cm}$ cada, para o plantio. Foram plantadas em junho de 1995. uma maniva por cova a uma profundidade de $5,0 \mathrm{~cm}$, espaçadas por $1.0 \mathrm{~m}$ entre linhas e entre plantas.

Originalmente as amostras foram implantadas em blocos ao acaso com 80 tratamentos, duas repetiçōes e uma planta por parcela, em campo experimental na Fazenda Anhembi do Departamento de Genética da ESALQ/USP. Entretanto, devido a problemas climáticos, como incidência de granizo, e de não brotamento de repetições, houve muitas perdas de indivíduos, exigindo que os dados de morfologia fossem tomados em apenas uma repetição. Isso inviabilizou as análises 
univariadas dos caracteres morfológicos.

Após 9 meses, foram obtidas manivas dos indivíduos adultos $e$ plantadas em saquinhos plásticos em casa de vegetação nas dependências do Departamento de Genética da ESALQ/USP, para se obter material para as análises de eletroforese de isoenzimas.

2) Amostras coletadas ao acaso sob identificação do agricultor em 1996 em Praia Grande, Iporanga.

As estacas de cada individuo amostrado em Praia Grande, não eram de tamanho adequado para a obtenção de mais de uma repetição, e portanto optou-se por garantir a sobrevivência dos indivíduos plantando-se duas manivas em uma única cova, à profundidade de 5,0 cm, e espaçadas por 1,0 metro entre plantas e 1,5 metros entre linhas. Desta forma, não foi possivel plantar as amostras sob delineamento de blocos ao acaso, como na primeira amostragem, sendo então utilizado delineamento totalmente ao acaso com 340 tratamentos com uma repetição, em campo experimental da Fazenda Anhembi do Departamento de Genética da ESALQ/USP.

Pelo grande número de indivíduos, o material para as análises de eletroforese de isoenzimas foi coletado das plantas adultas do experimento. Folhas recém expandidas eram coletadas por amostra, $e$ mantidas a baixa temperatura para posterior análise.

Como houve incidência de bacteriose (Xanthomonas campestris pv manihotis (Arthaud-Berthed Starr) na época de avaliação experimental de campo, os indivíduos amostrados em Praia Grande não foram avaliados morfologicamente. 
3) Amostras coletadas ao acaso sob identificação do agricultor em 1997 em Ariri.

As amostras coletadas foram plantadas em canteiros nas dependências do Departamento de Genética da ESALQ/USP, apenas para fornecer material para as análises de eletroforese de isoenzimas. Portanto não houve qualquer delineamento experimental.

\subsection{Descritores botânicos avaliados}

A caracterização botânica das amostras é feita através do uso de descritores, sendo que a variação observada dentro de cada um é conhecida como estado (Manly, 1994). A escolha dos descritores foi baseada nos trabaihos de Cury (1993) e Gulick et al. (1983), com modificações. Priorizou-se os descritores que podem ser avaliados no estado juvenil de desenvolvimento, e de alta herdabilidade.

Os descritores e seus estados são:

FOLHAS:

1. Cor do broto foliar (CBF)

1 - verde

2 - verde arroxeado

3- roxo

2. Cor da folha adulta (CFA)

1 - verde claro 
2 - verde

3 - verde escuro

3. Cor do peciolo das folhas adultas (CPE)

1 - verde

2 - verde avermelhado

3 - vinho

4 - roxo

4. Cor da base da nervura da folha (CBN)

1 - verde

2 - verde arroxeado

3 - vinho

4 - roxo

5. Morfologia do lóbulo foliar (MLF)

1 - linear

2 - lanceolada

3-oblonga

4 - obovada

6. Sinvosidade do lóbulo foliar (SLF)

1 - lisa

2 - intermediário

3 - forte

7. Número de lóbulos da folha (NLF) 
8. Comprimento do peciolo (COP)

9. Comprimento folha (COF)

10. Comprimento do lóbulo médio (CLM)

11. Largura do lóbulo médio (LLM)

12. Comprimento do primeiro lóbulo à direita do lóbulo central (CPL)

13. Largura do primeiro lóbulo à direita do lóbulo central (LPL)

CAULE:

14. Cor do caule jovem (CCJ)

I - verde

2 - verde claro com manchas roxas

3 - verde com manchas roxas

4 - verde escuro

5 - roxo esverdeado

15. Cor do caule adulto sem a película externa (CCA)

1 - verde amarelado

2 - verde

3 - verde avermelhado

4 - verde escuro

16. Proeminência das cicatrizes foliares (PCF)

1 - pouca

2 - média

3 - muita 
$4-$ rosa

5 - roxa

\subsection{Eletroforese de isoenzimas}

Eletroforese de isoenzimas é uma técnica já estabelecida em estudos taxonômicos e utilizada com bastante sucesso para reconhecimento e separação de diferentes cultivares de um mesmo taxon (Harborne, 1984). Segundo este autor, quando caracteres morfológicos ou anatômicos exibem extrema uniformidade, técnicas como de eletroforese são úteis pois "tipificam" os cultivares de uma dada espécie. Segundo Snaydon (1984), muitas evidências indicam que os padrões de variação intraespecíficos são muito mais contínuos que discretos, e que a variação exibida entre populações, entre indivíduos dentro de populaçōes e dentro de individuos pode ser adequadamente descrito por amostragens adequadas, e por uma variedade de técnicas que envolvem atributos morfológicos, fisiológicos e bioquímicos. Dentre os atributos bioquímicos destaca a técnica de eletroforese de isoenzimas e análise isoenzimática como ferramentas para se entender a estrutura da variação intraespecífica.

\subsection{Escolha dos sistemas enzimáticos}

A escolha dos sistemas enzimáticos que apresentavam melhores resoluçōes foi precedida de um grande número de testes. Ao todo, foram testadas 20 enzimas, quanto à resolução, estabilidade, polimorfismo e combinação de tampões de cuba e gel mais 
adequados. Tanto sistemas que apresentavam polimorfismo como monomortismo na segregação das bandas foram incluídos, resultando então em 11 sistemas enzimáticos úteis (Tabela 1).

Tabela 1. Total de sistemas testados e aqueles incluídos na análise para cálculo de distância genética.

\begin{tabular}{|c|c|c|}
\hline Enzima & Código* & Sigla \\
\hline Álcool Desidrogenase & E.C. 1.1.1.1. & $\mathrm{ADH}$ \\
\hline Alfa Esterase & E.C. 3.1.1.1 & $\alpha-E S T * *$ \\
\hline Beta Esterase & E.C. 3.1.1.1 & $\beta$-EST \\
\hline Beta Galactose Desidrogenase & E.C. 1.1 .1 .48 & GLDH \\
\hline Catalase & E.C.1.11.1.6 & $\mathrm{CAT}^{* *}$ \\
\hline Fosfatase Alcalina & E.C. 3.1.3.1 & ALP \\
\hline Fostase Ácida & E.C. 3.1 .3 .2 . & $A C P$ \\
\hline Fosfoglucomutase & E.C. 2.7 .5 .1 & $P G M^{* *}$ \\
\hline 6-Fosfocluconato Desidrogenase & E.C. 1.1 .1 .44 & 6PGDH \\
\hline Fosfoglucose Isomerase & E.C. 5.3 .1 .9 & $\left.P G\right|^{* *}$ \\
\hline Enzima Mílica & E.C. 1.1 .1 .40 & $E M^{* *}$ \\
\hline Glucose-6-Fosfato Desidrogenase & E.C. 1.1 .1 .49 & G6PDH \\
\hline Glucose Desidrogenase & E.C. 1.1 .1 .47 & GLUDH \\
\hline Glutamato Desidrogenase & E.C. 1.4 .1 .3 & $\mathrm{GDH}^{* *}$ \\
\hline Glutamato Oxalacetato Transaminase & E.C. 2.6 .1 .1 & $\mathrm{AAT}^{* *}$ \\
\hline Isocitrato Desidrogenase & E.C. 1.1 .1 .42 & $\mathrm{IDH}$ \\
\hline Leucina Aminopeptidase & E.C. 3.4 .11 .1 & LAP** \\
\hline Malato Desidrogenase & E.C. 1.1.1.37 & $\mathrm{MDH}^{* *}$ \\
\hline Manitol Desidrogenase & E.C. 1.1 .1 .67 & $\mathrm{MADH}^{* *}$ \\
\hline Peroxidade & E.C. 1.11 .1 .7 & PRX \\
\hline Xiquimato Desidrogenase & E.C. 1.1 .1 .25 & $S K D H^{* *}$ \\
\hline
\end{tabular}

* Código E.C. da "Enzime Commission of the International Union of Biochemistry" obtido a partir de Alfenas ef al. (1991).

** Sistema incluido na análise. 


\subsubsection{Gel de amido}

Os géis utilizados foram preparados a partir da combinação de Penetrose 30 e Amido da marca Sigma na proporção 2:1, a uma concentração de $12 \%$, utilizando três sistemas tampōes de acordo com a enzima que se procurava revelar. Para os sistemas SKDH, MDH, GDH, $\alpha$ EST, LAP e CAT, foram empregados tampão CM para o gel, diluido 1:20 do tampão da cuba, e o tampão CM para cuba, /Clayton \& Tretiak, 1972). para os sistemas PGM, MADH, EM, utilizou-se tampão TC para o gel a $3.5 \%$ do tampão da cuba, e TC para cuba (Soltis et al., 1983), e para os sistemas PGI e AAT, tampōes A+B, na proporção 1:9 para o gel, e o tampão A para cuba (Scandalios, 1969). Os tampões são descritos a seguir:

a) Tampão A (pH 8,3)

Hidróxido de lítio $2.098 \mathrm{~g}$

Ácido bórico $11,748 \mathrm{~g}$

$\mathrm{H}_{2} \mathrm{O}$ q.s.p. $1000 \mathrm{mi}$

b) Tampão B (pH 8,3)

Tris

$6.178 \mathrm{~g}$

Ácido citrico $(0,086 \mathrm{M})$ $1,68 \mathrm{~g}$

$\mathrm{H}_{2} \mathrm{O}$ q.s.p. $1000 \mathrm{ml}$

c) Tampão Citrato de morfolina $(\mathrm{CM})(\mathrm{pH} 6.1)$

Cuba:

Ácido citrico(0,040M)

$8.41 \mathrm{~g} / 1$

$\mathrm{N}$-(3-Aminopropyl) morfolina - 0,068Mi)

$10 \mathrm{mi} / \mathrm{i}$

Gel: diluição 1:20 
d) Tampão Tris-Citrato (TC)

Cuba:

Tris

$27.0 \mathrm{~g} / \mathrm{i}$

Ácido Cítrico $(0,086 \mathrm{M})$

$18,07 \mathrm{~g} / 1$

corrigir $\mathrm{pH}$ para $7,5 \mathrm{com} \mathrm{NaOH}$

Cada gel foi preparado em um Kitassato sob aquecimento em forno de microondas por $1 \mathrm{~min} 45 \mathrm{seg}$ depois de misturado ao tampão previamente levado à ebuliçāo por $2 \mathrm{~min}$. Posteriormente o mesmo era colocado, em uma placa de vidro, ficando com as dimensōes $15,5 \times 13 \times 1,8 \mathrm{~cm}$. Então era resfriado a temperatura ambiente antes de ser colocado em geladeira, para o uso no dia seguinte pela manhã. O gel retirado da geladeira a temperatura de $4^{\circ} \mathrm{C}$ recebia então as amostras.

\subsubsection{Extração, aplicação das amostras e revelação}

Amostras de folhas recém expandidas foram coletadas na casa de vegetação no caso dos indivíduos de Ariril, no canteiro para os de Ariri2 e no campo experimental na Fazenda Anhembi, para os de Praia Grande.

Os tecidos foram macerados com auxillio de um bastão de vidro, em uma placa de acrílico suficientemente grande para receber todas as amostras ao mesmo tempo. Cada etapa de maceração envolvia de 20 a 22 amostras, isto é, 20 a 22 individuos. Cada amostra, de 0,30g, recebia 4 gotas de tampão de extração.

Chegou-se a estas quantidades após diversos testes empregandose quantidades e composições de tampão de extração diferentes, ou 
simplesmente água. Em mandioca, assim como em muitas plantas, o processo que envolve homogeneização do tecido faz com que haja interação entre proteínas e compostos secundários. A adição de tampões de extração reduz a interação entre estes compostos, onde se destacam os fenóis, e proteínas, ou seus produtos de reação (Kephart, 1990). Desta maneira foi utilizado o tampão de extração com a seguinte composição:

$\begin{array}{ll}\text { Tris } 0.1 \mathrm{M} \mathrm{pH} 7.5 & 200 \mathrm{ml} \\ \text { Sacarose } 0.2 \mathrm{M} & 6.892 \mathrm{~g} \\ \text { PVP } 0.6 \% & 1.20 \mathrm{~g} \\ \text { EDTA InM } & 0.06724 \mathrm{~g} \\ \text { BSA } 0.1 \% & 0.2 \mathrm{~g}\end{array}$

Após a maceraçāo, os homogeneizados eram absorvidos em papel de filtro $(4 \mathrm{~mm} \times 1,7 \mathrm{~mm}$ ) e colocados no gel. Este era repartido a aproximadamente $5 \mathrm{~cm}$ a partir da base onde recebia as amostras. Este procedimento facilitava a colocação das amostras além de permitir a migração eficiente das bandas, já que todas os sistemas apresentavam bandas anódicas ou catódicas de pouca migração. Após o enfileiramento das amostras, juntava-se as partes cortadas montando um único elemento de gel. Nas duas extremidades do gel era colocada uma solução de Azul de bromefenol ${ }^{3}$ para marcar a linha de frente durante a migração, e usar como referência de migração. Quando a frente distanciava-se $7.5 \mathrm{~cm}$ da sua origem, o processo de migração era interrompido e os géis eram cortados em 5 fatias de aproximadamente

\footnotetext{
${ }^{3}$ Azul de Bromefenol: $0,04 \mathrm{~g} \mathrm{em} 100 \mathrm{ml} \mathrm{H}_{2} \mathrm{O}$
} 
2,0 mm de espessura cada. Procedia-se então a coloração.

A coloração era efetuada imediatamente a interrupção da corrida e executada para as enzimas especificas como descrito a seguir. Sistemas:

PGM - Fosfoglucomutase (Alfenas et al. 1991)

1. Glucose 1 fosfato, $\mathrm{Na}_{2}$ $0.125 \mathrm{~g}$

2. EDTA $0.025 \mathrm{~g}$

3. $\mathrm{NADP}^{+}$ $1,0 \mathrm{ml}(10 \mathrm{mg})$

4. MTT $1,0 \mathrm{ml}(10 \mathrm{mg})$

5. PMS. $1,0 \mathrm{ml}(10 \mathrm{mg})$

6. $\mathrm{MgCL}_{2}(1 \%)$ $1.0 \mathrm{ml}(10 \mathrm{mg})$

7. TRIS-HCL $(0.1 \mathrm{M}, \mathrm{PH} 8.5)$ $50 \mathrm{ml}$

8. Glucose-6-fosfato desidrogenase (G6PDH) ....0.02ml

LAP - Leucil Aminopeptidase (Alfenas et al. 1991)

1. Tampão TRIS-maleato (ph $5,2-0,2 \mathrm{M}$ )............ $50 \mathrm{ml}$

2. L-Leucyl B-Naftilamida.................................. 0.02g

3. Fast Garnet GBC........................................ $0,025 \mathrm{~g}$

* Dissolver o substrato em $10 \mathrm{ml}$ solução metanol $10 \%$ por 5 minutos

SKDH - Xiquimato desidrogenase (Alfenas et al. 1991)

1. Ácido xiquímico $0,05 \mathrm{~g}$

2. NADP+ $1,0 \mathrm{ml}(10 \mathrm{mg})$

3. PMS. $1.0 \mathrm{~m} / 1 \mathrm{mg})$

4. MTT OU NBT $1.0 \mathrm{ml}(1 \mathrm{mg})$

5. Tris - HCL $(0.1 \mathrm{M}-\mathrm{pH} 8.5)$. $50 \mathrm{ml}$

CAT - Catalase (Cheliak \&Pitel, 1984)

1. $\mathrm{H}_{2} \mathrm{O}$ destilada. $50 \mathrm{ml}$

2. Ácido acético $0.5 \mathrm{ml}$

3. lodeto de Potássio. $0.5 \mathrm{~g}$

* Colocar o gel em $\mathrm{H}_{2} \mathrm{O}_{2}(0.5 \%)$ por 1 min e depois lavar com água 
PGI - Fosfoglucose isomerase (Alfenas et al. 1991)

1. Frutose-6-fosfato. $0,0375 \mathrm{~g}$

2. NADP+ $1.0 \mathrm{ml}(10 \mathrm{mg})$

3. MTT OU NBT $1.0 \mathrm{ml}(10 \mathrm{mg})$

4. PMS $1,0 \mathrm{ml}(1,0 \mathrm{mg})$

5. $\mathrm{MgCl}_{2}(1 \%)$ $1.0 \mathrm{ml}(10 \mathrm{mg})$

6. Tris-HCL $(0,1 \mathrm{M}-\mathrm{pH} 8,0)$ $50 \mathrm{ml}$

7. Gluocose-6-fosfato desidrogenase (G6PDH) $0,01 \mathrm{ml}$ lounid.

MADH - Manitol Desidrogenase Alfenas ef al. 1991

1. Manitol $50 \mathrm{mg}$

2. $\mathrm{NADP}+, \mathrm{Na}_{2}$ $1,0 \mathrm{ml}(10 \mathrm{mg})$

3. MTT oU NBT. $1,0 \mathrm{ml}(10 \mathrm{mg})$

4. PMS $1,0 \mathrm{ml}(1,0 \mathrm{mg})$

5. Tris $\mathrm{HCL}(0,1 \mathrm{M}, \mathrm{pH} 8,5)$ $50 \mathrm{ml}$

MDH - Malato desidrogenase (Brewer \& Sing. 1970. Modificado)

1. NAD $0.033 \mathrm{~g}(3.3 \mathrm{ml})$

2. PMS $0,0015 \mathrm{~g}(1,5 \mathrm{ml})$

3. NBT. $0,0125 \mathrm{~g}(1,2 \mathrm{ml})$

4. Tampão Tris - Ácido Málico $(\mathrm{pH} 7,0)$ $50 \mathrm{ml}$

\section{EM - Enzima Málica}

1. Ídem MDH porém substitue NAD por NADP

AAT - Glutamato Oxaloacetato Transaminase (GOT) (Cheliak \& Pitel, 1984. Modificadol

1. Fast Blue $B B$ $0.15 \mathrm{~g}$

2. Piridoxal-5-Fosfato $0,001 \mathrm{~g}$

3. Ácido a-Aspártico $0,226 \mathrm{~g}$

4. Ácido a-Cetoglutâmico $0.0365 \mathrm{~g}$

5. Tampão C* $\left(\mathrm{NaH}_{2} \mathrm{PO}_{4}\right)$ $8,0 \mathrm{ml}$

6. Tampão D** $\left(\mathrm{NaH}_{2} \mathrm{PO}_{4}\right)$ $42 \mathrm{ml}$

* Tampão C $(\mathrm{pH} \mathrm{4,3)}$

1. $\mathrm{Na} \mathrm{H}_{2} \mathrm{PO}_{4}$. $27.5 \mathrm{~g}$

2. $\mathrm{H}_{2} \mathrm{O}$ destilada $1000 \mathrm{ml}$
** Tampão D (pH9,2)
1. $\mathrm{Na}_{2} \mathrm{HPO}_{4}$ $53.63 \mathrm{~g}$
2. $\mathrm{H} 2 \mathrm{O}$ destilada $1000 \mathrm{ml}$ 
$\propto$-EST - Esterase (Scandalios, 1969. Modificado)

1. $\mathrm{H}_{2} \mathrm{O}$ destilada........................................................ $20 \mathrm{ml}$

2. Tampāo C .............................................................. 25ml

3. Tampão D .....................................................................

4. Fast Garner GBC.................................................. $0.04 \mathrm{~g}$

5. a-Naftil acetato (acetona:água 1:1) ...................... 1,5ml

GDH - Glutamato desidrogenase (Alfenas et al. 1991. Modificado)

1. Ácido L-Glutâmico .................................................... 1, $\mathrm{og}$

2. MTT ou NBT ….................................................... 1,5ml

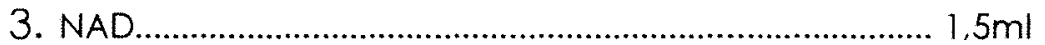

4. PMS …........................................................... $0.5 \mathrm{ml}$

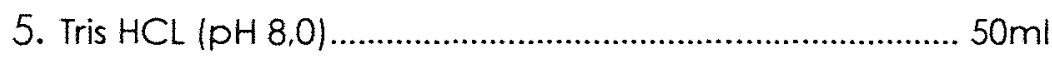

Após a revelaçāo das isoenzimas, o gel era lavado com água destilada e elaborava-se o zimograma em papel milimetrado. A posição das bandas era anotada e a configuração desenhada. O gel então era fixado em solução de glicerina a 10\%, e congelado. 
3.6 Métodos analíticos

\subsubsection{Distância euclidiana média}

Para obter as estimativas de divergência fenotípica, foi calculada a partir dos descritores estandardizados, a distância evclidiana média entre as amostras. Esta estimativa de distância corrige variação de número de variáveis, permitindo comparar matrizes com número diferente de descritores.

O cálculo da distância é dado por:

$$
d_{i j}=\sqrt{ }\left[\sum_{k=1}^{p}\left(x_{i k}-x_{j k}\right)^{2}\right] / p
$$

onde:

$d_{i j}=$ distância euclidiana média entre os genótipos i e j.

$p=$ número de descritores.

As estimativas de distância entre amostras foram calculadas por roça e basearam as análises de agrupamento para os dados de morfologia.

3.6.2 Calculo do índice de similaridade genética - Coeficiente de semelhança simples ("Simple Matching")

O coeficiente de similaridade genética, foi calculado a partir da matriz de dupla entrada de dados de presença e ausência de bandas 
isoenzimáticas. O estudo de variabilidade inter e intra varietal baseou-se portanto no empregado do índice de concordância de Sokal \& Michener (1958), conhecido por "Simple Matching" amplamente utilizado. Este coeficiente, ao contrário de outros índices como o de Jaccard, atribui à ausência de uma banda entre dois indivíduos comparados o mesmo peso que a presença da banda correspondente. Considera-se então que para a diferenciação de genótipos de uma mesma espécie, a ausência do alelo teria o mesmo peso que a sua presença.

O coeficiente é definido por:

$\left.S_{i j}=(a+d) / a+b+c+d\right)$

onde:

$S_{i j}=$ Coeficiente de semelhança simples ("Simple Mathing")

$a=$ total de bandas isoenzimáticas presentes nos individuos i e j.

$b=$ total de bandas isoenzimáticas presentes no indivíduo ie ausentes no indivíduo j.

$c=$ total de bandas isoenzimáticas presentes no indivíduo je ausentes no indivíduo i.

$d=$ total de bandas isoenzimáticas ausentes nos individuos i e j. 


\subsubsection{Análise de agrupamento}

Para os caracteres morfológicos optou-se pela utilização, para todas as roças, de dois métodos de agrupamento do tipo hierárquico aglomerativo, sem sobreposição (SAHN) (Sneath \& Sokal, 1973): Ligações médias não ponderadas (UPGMA), onde o critério utilizado envolve a média da distância de todos os pares de objetos com um em cada grupo (Dunn \& Everitt, 1980) e método de Ward, que procura minimizar a variância entre OUT's (Unidade Taxonômoca Operacional), isto é, onde o critério utilizado para a ligaçāo de grupos é a soma dos quadrados das distâncias entre membros de um grupo e o centróide do grupo. A próxima ligação será feita utilizando o par de grupos que produz o menor aumento nesta soma (Sneath \& Sokal, 1973). Para os dados de isoenzimas foram utilizados três métodos aglomerativos nos estudos dos agrupamentos: ligação simples, que na ligação de grupos utiliza a distância mínima, ou a semelhança máxima, entre qualquer par de individuos, um em cada um dos grupos; UPGMA; e ligação completa, que ao contrário da ligação simples utiliza a distância máxima, ou a semelhança mínima, entre qualquer par de indivíduos, sendo um de cada grupo, para ligar dois grupos. Estes três métodos foram utilizados nos estudos dos agrupamentos, mas serão apresentados aqueles que mostraram complementação de informaçōes. Normalmente é escolhido apenas um método para mostrar as ligações entre grupos, mas utilizar vários métodos diferentes permite "visualizar" melhor a estruturação dos dados avaliados. 


\subsubsection{Número de grupos formados}

Um problema que se depara na análise de dendrogramas é quanto ao número de grupos formados presentes nos dados avaliados (Riboldi, 1986).

Para resolver isso, métodos arbitrários, ou informais, foram sugeridos por Friedman \& Rubi (1967), os quais envolvem o exame das diferenças entre os níveis de fusão no dendrograma. O número correto de grupos seria obtido pela verificação do ponto de alta mudança de nivel.

Este procedimento foi realizado no trabalho, de forma que para facilitar a compreensão e deixar a discussão mais objetiva, serão discutidos aqueles dendrogramas mais significativos e aqueles que contenham informações importantes do ponto de vista da identificação feita pelo agricultor comparada à identificação pela avaliação morfológica.

Segundo Dunn \& Everitt (1980), O uso de métodos de agrupamento sugere algumas questões essenciais quanto a representatividade dos grupos exibidos. A questão primordial seria: Até que ponto os grupos não estão sendo formados sobre dados aleatórios sem qualquer estrutura fenética real?

Para encontrar grupos reais e responder a este tipo de problema, - conhecimento prévio dos dados coletados e a natureza dos caracteres avaliados é essencial, sendo a associação de metodologias de análise, como componentes principais (PCA) e coordenadas principais (PCO) bastante útil para este propósito. 


\subsubsection{Coeficiente de correlação cofenético}

A mudança de grupo entre individuos em niveis infraespecificos, que pode ocorrer nos diferentes métodos de agrupamento, deve estar diretamente relacionada à estruturação dos dados avaliados. Para avaliar a correspondência entre a matriz de coeficientes originais e o dendrograma produzido pela análise, o coeficiente de correlação cofenético de Sneath \& Sokal (1973) pode ser bastante útil (Dubes \& Jain, 1979).

Este coeficiente é gerado pela correlação entre a matriz de coeficientes original e a matriz de valores cofenéticos que corresponde ao dendrograma produzido pela análise. É simplesmente a correlação dos produtos dos momentos de $n(n-1) / 2$ entradas da matriz original, com $n(n-1) / 2$ entradas da matriz cofenética $C$, onde $C_{i j}$ é definido como o primeiro nivel no dendrograma na qual as OUT's i e jocorrem no mesmo grupo (cluster).

Em geral, quanto mais alto o valor desta correlação, melhor é a representação dos dados originais fornecida pelo dendrograma. Rohlf \& Fischer (1968) sugerem que o valor médio de um coeficiente tende a decrescer com n aumentando e tende a ser independente do número de caracteres avaliados. O valor acima de 0,80 seria suficiente para rejeitar a hipótese nula, isto é, que não há classificação ou que os agrupamentos não são satisfatórios. Entretanto, existem controvérsias quanto a este valor. Rohlf (1970) citado por Dunn \& Everitt (1980), coloca que mesmo correlações perto de 0,90 não garantem que 0 dendrograma sirva como um bom sumário das relaçōes fenéticas. Além disso, pode haver distorção dos valores, dependendo do método de 
agrupamento utilizado (Shepherd, 1997)4, portanto $\bigcirc$ uso deste coeficiente deve ser feito com cautela mas é um bom auxiliar na interpretação dos dendrogramas.

\subsubsection{Análise de componentes principais (PCA)}

A utilidade dos componentes principais está na simplificação dos dados originais quanto às relações do conjunto $p$ de variáveis. Desta forma, pode-se avaliar as relações entre amostras e entre variedades, bi ou tridimensionalmente, de maneira simplificada. Sendo assim, o método de componentes principais permite reduzir o número inicial de caracteres, sem que haja perda significativa de informação. A eficiência do método então está relacionada à quantidade de variação total contida nos $n$ primeiros componentes, $\operatorname{com} n<p$.

A nova descrição dos dados, através dos componentes, vai depender da porcentagem de variação total que cada componente contém, quando arranjados em ordem decrescente de variância. Assim, o primeiro componente é definido como aquele de maior variação total encontrada nos dados originais. De forma correlata, a medida de variância em cada componente, ou eixo, pode ser descrita pelos autovalores.

A metodologia de análise dos componentes principais encontrase detalhadamente descrita por Mardia et al. (1979). Dunn \& Everitt (1980), Morrison (1981), Chatfield \& Collins (1986), Manly (1994).

\footnotetext{
${ }^{4}$ Professor George Shepherd. Depto. de Botânica (UNICAMP) -Comunicação pessoal.
} 


\subsubsection{Análise de coordenadas principais (PCO)}

A análise de coordenadas principais (Gower, 1966) é um método de ordenação que produz um novo sistema de coordenadas a partir da matriz de distância ou semelhança entre objetos. Estas distâncias são refletidas no espaço com um número reduzido de dimensões/Culloch, 1990). Ao contrário da análise de componentes principais, este método de ordenação não indica as relações das variáveis originais pois apenas a matriz de distância ou semelhança entre objetos é utilizada. O método utiliza a abordagem dos autovalores e pode ser considerado uma generalização da análise de componentes principais (PCA) (Manly, 1994). Portanto, quanto mais variância se acumula nos primeiros autovalores obtidos, melhor é a representação das relaçōes entre objetos, descrevendo-os em relação às coordenadas produzidas. Além disso, a representação gráfica é possivel, já que são produzidos os escores para cada objeto. A grande vantagem deste método é a flexibilidade, já que permite utilizar qualquer coeficiente de distância métrico. Para descrições mais detalhadas da técnica, bastante úteis sāo Manly (1994), Pielou (1984), e Dunn \& Everitt (1980).

Esta metodologia foi utilizada em mandioca por Colombo (1997). estudando relações fenéticas entre variedades de mandioca de diversas regiões do mundo. O autor não obteve autovalores muito elevados nas duas primeiras coordenadas, utilizando o coeficiente de semelhança simples, porém encontrou certa coerência na formação de grupos na representação gráfica. Pouca variância também foi extraida nas primeiras coordenadas das análises de Brondani (1996). estudando diferentes espécies do gênero Manihot $e$ utilizando o 
coeficiente de similaridade de Jaccard. As três primeiras coordenadas acumularam apenas $38,39 \%$ da variação total, não permitindo a formação de grupos bem definidos graficamente no espaço tridimesional.

\subsubsection{Correlação de matrizes - Teste de Mantel}

Para verificar a correlação entre as distâncias obtidas pela análise da morfologia com as distâncias obtidas pelos dados de eletroforese de isoenzimas, utilizou-se do teste de Mantel (1967).

O teste de aleatorização de Mantel envolve a medida de associação entre os elementos de duas matrizes, fazendo a correlação entre os elementos correspondentes de cada uma. É obtida então a correlação dos produtos dos momentos, $r$. Determina também a significância desta correlação pela comparação com a distribuição de correlações encontradas a partir de sucessivas aleatorizações dos elementos de uma das matrizes (Manly, 1991). Compara portanto, a grosso modo, a correlação original com sucessivas correlações obtidas entre alocações ao acaso dentro de uma das matrizes. Esta matriz que terá os dados realocados é determinada como matriz $E$, e as sucessivas realocações produzem matrizes $E_{R}(R=$ "randomization"), sendo a outra determinada como matriz M. Um valor $Z$ pode ser obtido então usando $M \in E$. Repetindo este procedimento usando diferentes ordens de $E$, isto é $E_{R}$, produz-se uma distribuiçāo aleatorizada de Z. Checa-se então se o valor observado de $Z$ (original) é um valor da distribuição aleatoriżada de Z. A idéia é que se duas matrizes de distância não são correlacionadas, a matriz $E$ é apenas um matriz aleatória como 
qualquer matriz $E_{R}$, e a correlação encontrada não tem significado.

Em outras palavras se duas matrizes têm correlação positiva então o valor de $Z$ tenderá a ser muito maior que os vaiores dado ao acaso (Manly, 1991).

Colombo (1997) encontrou um valor de $r=0,32(p<0,001)$ entre matrizes de similaridade obtidas a partir de dados moleculares $e$ botânicos. Lapointe \& Legendre (1992) citados por Colombo (1997) estudaram 12 OUT's (unidades taxonômicas operacionais) encontrando $r=0,5$, significante a $1,0 \%$ de probabilidade.

No presente trabaiho, o teste de Mantel foi realizado com as matrizes de distância, obtidas das análises morfológica e isoenzimática dos indivíduos coletados nas roças de Ariri dos anos de 1995 e 1997, pois para as roças de Praia Grande não foi realizada análise dos caracteres morfológicos. Para o teste, as matrizes de semelhança foram transformadas em matrizes de distância.

Segundo Manly (1991) para obter significancias a $1,0 \%$ de probabilidade são necessárias 5000 permutações, portanto adotou-se esta determinação do autor para os cálculos. Uma descrição pormenorizada do teste de Mantel pode ser encontrada em Manly (1991) e no manual do programa estatística Ntsys (Rohlf, 1992).

\subsection{Programas de computador utilizados para as análises}

Para o cálculo das distàncias euclidianas médias, dos coeficientes de semelhança simples, e para as análises de ordenação, foi utilizado o programa Fitopac de autoria do Prof. George Shepherd do Departamento de Botânica da Universidade Estadual de Campinas 
(UNICAMP). Para elaboração dos dendrogramas e gráficos de ordenação, tanto para PCA como para PCO, foi utilizado o programa STATISTICA for Windows (StatSoft, 1996). E para elaboração do teste de Mantel foi utilizado o programa Ntsys (Rohlf, 1992). 


\section{RESULTADOS E DISCUSSÃO}

\subsection{Descrição dos locais}

Para a caracterização das roças estudadas, foram considerados os parâmetros descritos na metodologia. Entretanto é importante salientar que as análises mais refinadas, no sentido de melhor descrição, foram concentradas no bairro rural de Ariri, Cananéia. Esta escolha foi feita em função da representatividade do sistema itinerante, da facilidade de acesso ao local, e da facilidade logística na conduçāo de entrevistas e coleta de material. Sendo assim, embora tenham sido coletadas etnovariedades de mandioca em ambas as comunidades, em Ariri foram conduzidas entrevistas mais detalhadas inclusive sobre o sistema itinerante.

Em ambos os locais, as famílias escolhidas e entrevistadas utilizam a técnica de agricultura itinerante como forma de cultivo das espécies por eles manejadas. Em Ariri, as espécies são cultivadas visando principalmente a subsistência, com vendas casuais de farinha de mandioca na própria comunidade, enquanto que em Praia Grande se observa maior integração da produção com uma finalidade comercial, principalmente de cultivos de milho e feijão 


\subsubsection{Comunidade de Praia Grande}

As informações levantadas em campo dizem respeito dos aspectos gerais do sistema agrícola utilizado nesta localidade. A dificuldade de acesso, as intensas chuvas e a impossibilidade de retorno impediram o detalhamento desejado.

As roças estudadas estão formadas em terrenos de topografia bastante acidentada, sendo aquelas verdadeiramente itinerantes são as roças 1 e 2, localizando-se em áreas com 30 a 40 de inclinação, distantes cerca de 400 metros da margem do Rio Ribeira de Iguape. As roças 1 e 2 pertencem a dois dos mais antigos agricultores de Praia Grande, com 60 e 65 anos de idade respectivamente. Eles são considerados, pela comunidade, como grandes conhecedores das práticas agrícolas, assim como das variedades cultivadas no local. Nestas duas roças as variedades são plantadas misturas e é utilizado o sistema de cova, onde são colocadas duas manivas para brotamento. O plantio se faz preferivelmente no periodo da lua crescente, nos meses de junho a novembro e, de forma geral, a colheita de mandioca é feita em 1 ano para mesa e 1,5 ano para farinha. Isso corresponde ao encontrado em outros relatos sobre utilização de mandioca, (Queiroz, 1983; Ribeiro, 1997 e Schmidt, 1958). Neste local não foi relatada a presença de variedades mais precoces ou mais tardias.

As roças 3 e 4 estão localizadas nos terrenos considerados mais férteis para cultivo, presentes nas margens do rio Ribeira de Iguape. Estas são maiores que as roças 1 e 2, sendo que o periodo de utilização pode chegar a 4 anos. O agricultor, dono das roças 3 e 4 , é mais jovem que os 
agricultores donos das roças 1 e 2, tendo aproximadamente 35 anos. Ele mostrou preferência por plantar apenas a variedade "Pão do Céu", por considerá-la mais adaptada a este tipo de terreno. Apesar desta aparente especificidade, esta etnovariedade está presente também nas "roças do morro".

Não foram encontradas roças comunitárias, sendo todas elas familiares, com utilização de mão de obra familiar preponderantemente. Em Praia Grande, existe maior ênfase em culturas comerciais: foram observadas roças de 1 ha de milho, feijāo, arroz e cana-de-açúcar, plantadas em monocultivo e não consorciadas como nas roças familiares que tinham como principal finalidade a subsistência. Segundo os informantes, a mandioca em Praia Grande tem menos área ocupada e são poucas as famílias que possuem casa de farinha. As justificativas para o diminuição das áreas de cultivo são os baixos preços conseguidos no mercado e a própria falta de mercado para a farinha. Este problema foi apontado por todos os informantes das famílias contatadas.

\subsubsection{Comunidade de Ariri}

Neste local (Figuras 2 e 3), foi possivel obter informaçōes das espécies e das variedades cultivadas com a mandioca (Figuras 4 e 5). Encontramos 62 etnovariedades das 14 espécies ainda cultivadas (Tabela 2). 


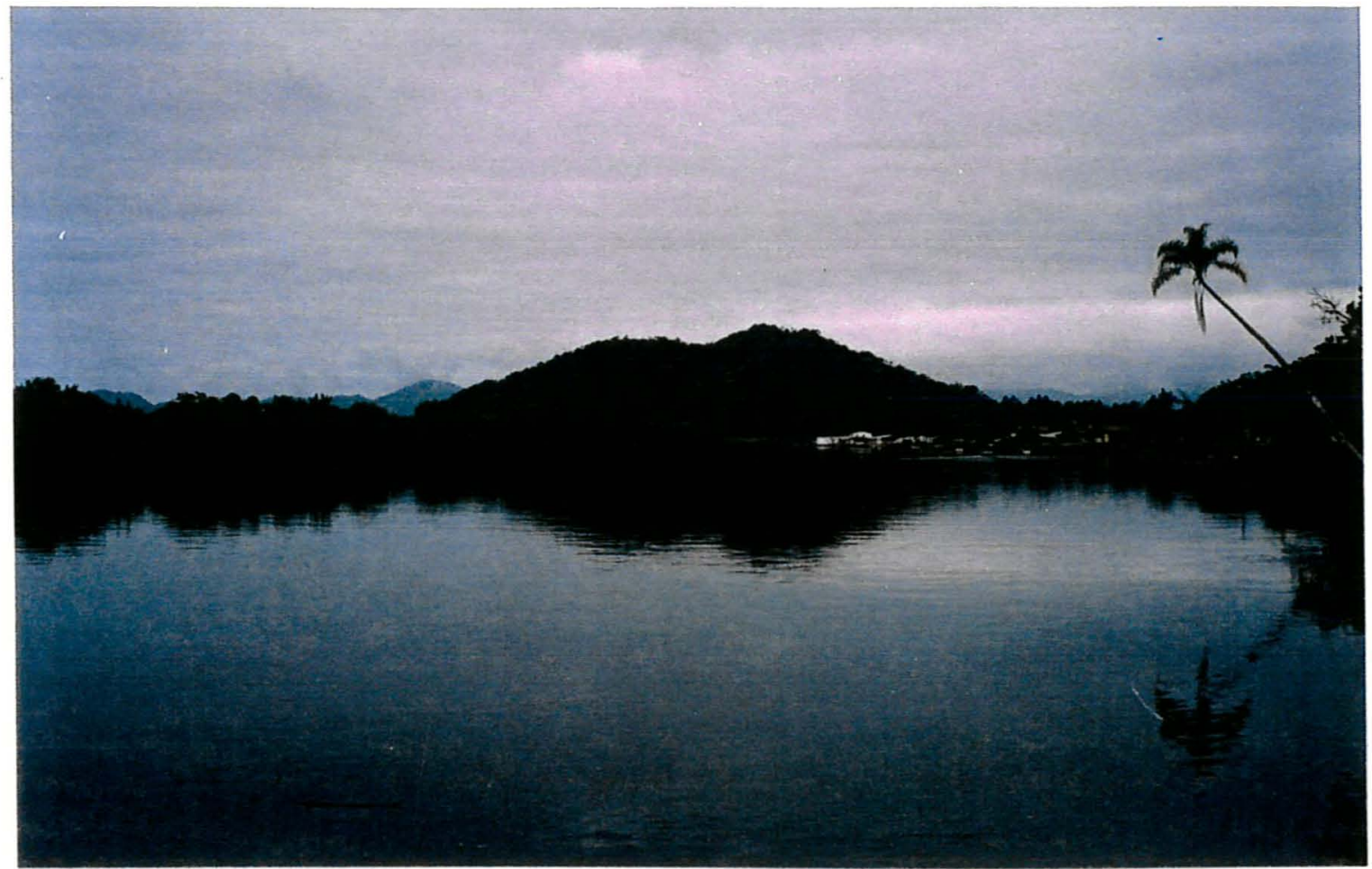

Figura 2. Comunidade de Ariri vista a partir da entrada do canal que dá acesso à comunidade

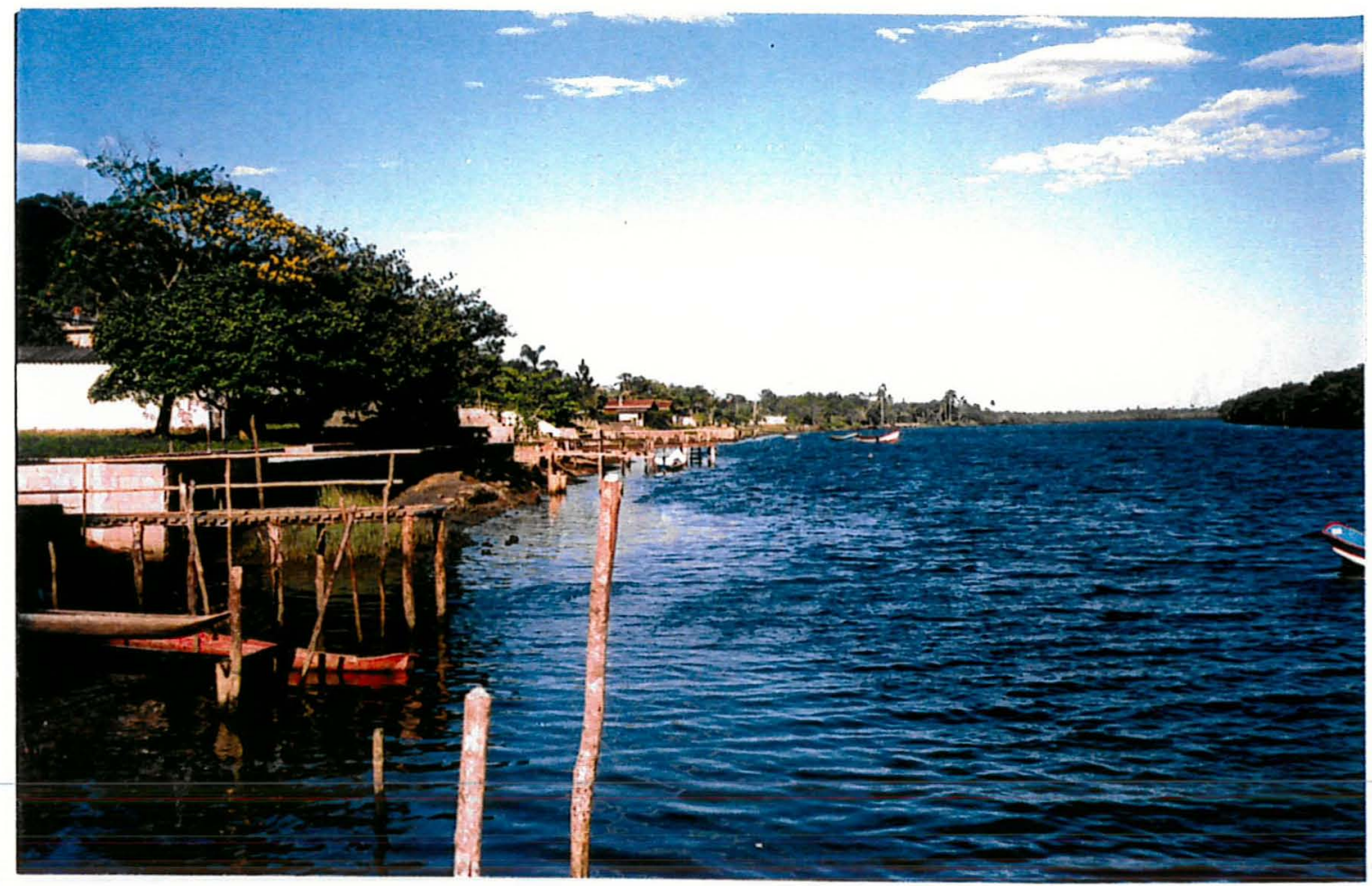

Figura 3. Comunidade de Ariri em detalhe 


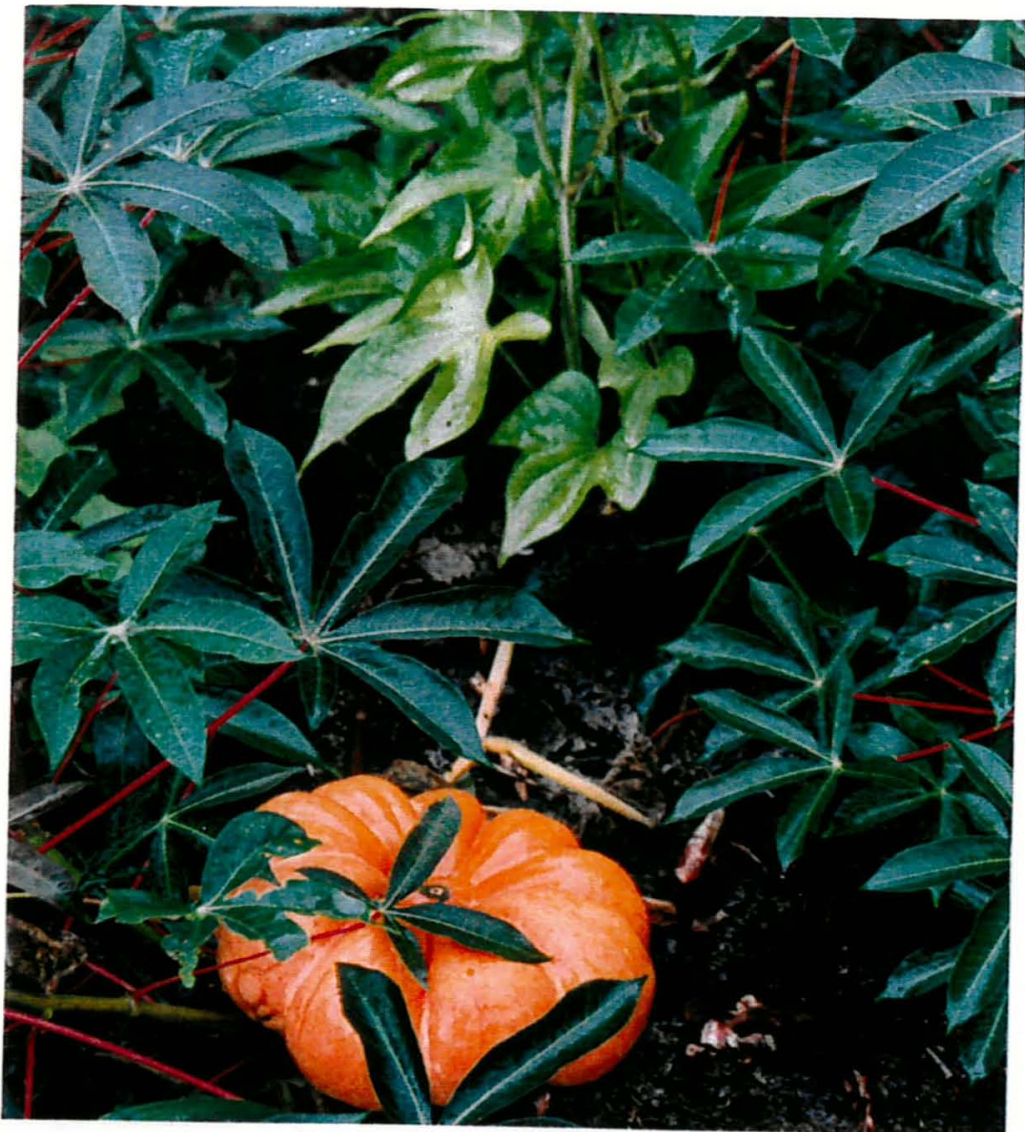

Figura 4. Roça 1, com culturas em consorciação: mandioca, cará e moranga (janeiro de 1995).

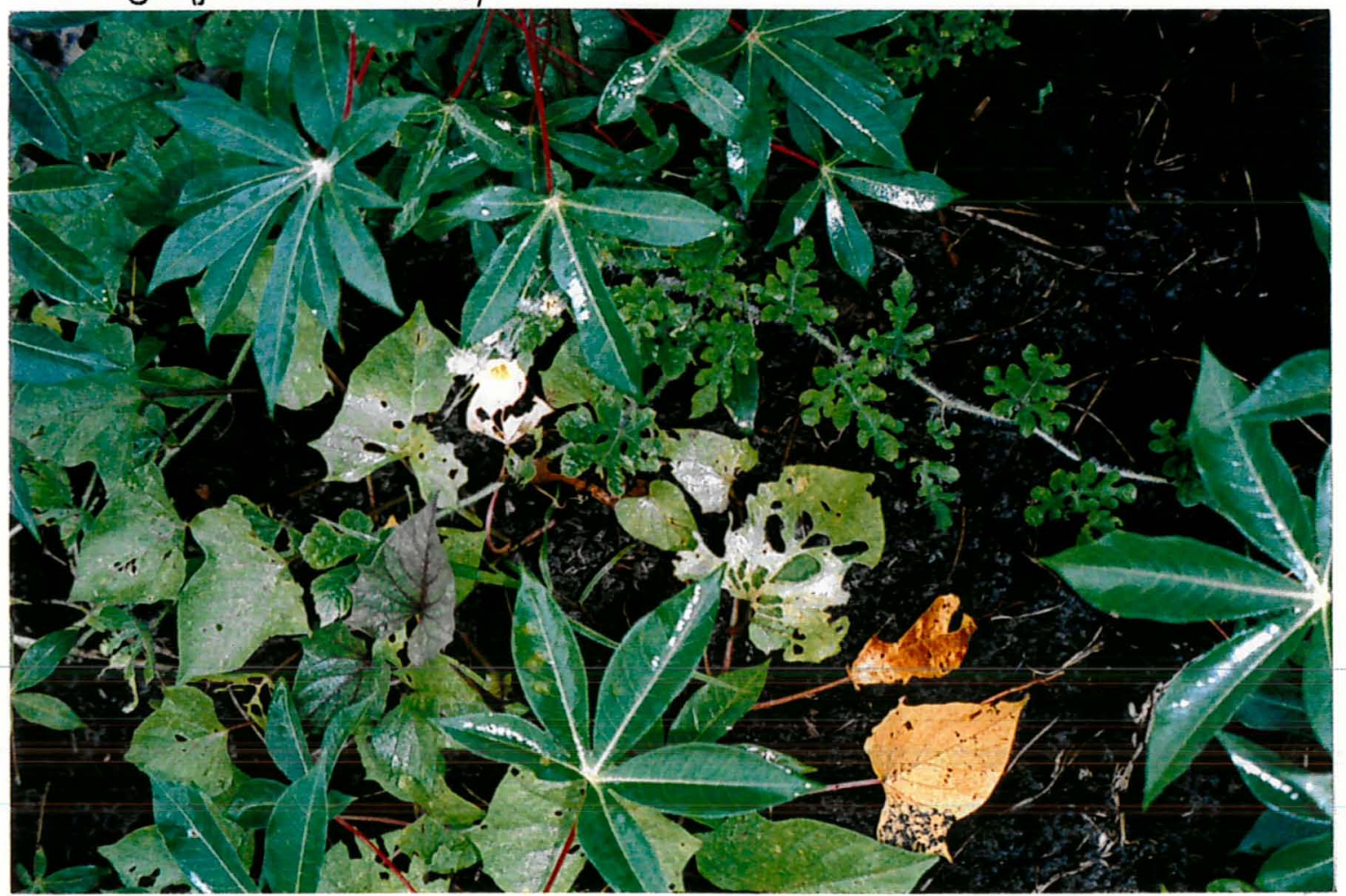

Figura 5. Roça 1, com culturas em consorciação: mandioca, batatadoce e melancia (janeiro de 1995). 
Tabela 2. Espécies cultivadas e número de variedades presentes nas roças de Ariril, pertencentes a uma única familia de agricultores.

\begin{tabular}{|c|c|c|c|}
\hline Nome científico & Nome comum & Familia & NV \\
\hline Cucurbita maxima Duch. & Abóbora & Cucurbitaceae & 3 \\
\hline Oryza sativa $\mathrm{L}$. & Arroz & Graminae & 8 \\
\hline Musasp & Banana & Musaceae & 8 \\
\hline Ipomoea batatas Lam. & Batata doce & Convolvulaceae & 3 \\
\hline Saccarum officinarum $L$. & Cana de açúcar & Graminae & 6 \\
\hline Dioscoreasp & Cará & Dioscoreaceae & 6 \\
\hline Phaseolus vulgaris L. & Feijāo & Fabaceae & 11 \\
\hline Dioscoreasp & Inhame & Dioscoreaceae & 1 \\
\hline Manihot esculenta Crantz & Mandioca & Euphorbiaceae & 8 \\
\hline Citrullus lanatus (Thumb.) Matsum \& & Melancia & Cucurbitaceae & 1 \\
\hline \multicolumn{4}{|l|}{ Nakai } \\
\hline Cucumis melo L. & Melão & Cucurbitaceae & 1 \\
\hline Cucurbitasp & Moranga & Cucurbitaceae & 1 \\
\hline Zea mays L. & Milho & Graminae & 2 \\
\hline Cucumis sativus L. & Pepino & Cucurbitaceae & 2 \\
\hline Xanthosoma sagitfifolium (L.) Schott & Taiá (taioba) & Araceae & 1 \\
\hline Total & 14 & 8 & 62 \\
\hline
\end{tabular}

NV-Número de variedades

Entre as espécies cultivadas, destaca-se o maior número de variedades totais do que espécies, fato já amplamente discutido na literatura, como por Boster (1983) e Boster (1985), sendo que foi observada uma conjugação de espécies nativas de propagação vegetativa, com espécies introduzidas. Este aspecto mostra, em primeiro lugar, a presença de espécies muito semelhantes entre si no que diz 
respeito a forma de propagação, no caso vegetativa e a parte utilizada para consumo, isto é, raízes e tubérculos, como mandioca, cará, inhame e batata-doce. Além disso, mostra a habilidade do agricultor em integrar variedades de espécies diferentes dentro de um mesmo ambiente de cultivo, refletindo a herança local do manejo agrícola polivarietal.

A atividade agrícola fundamenta-se no contexto da subsistência familiar, sendo que o comércio restringe-se à venda de farinha de mandioca na própria comunidade. Segundo os informantes, a venda de farinha foi mais intensa no passado e os plantios tinham como finalidade, além do sustento da família, o comércio na cidade de Cananéia.

No sistema agrícola como um todo, as atividades são concentradas no âmbito familiar, participando tanto homens como mulheres. A atividade feminina ocorre principalmente nas fases de plantio da roça e preparo da farinha da mandioca. Diz-se que roça formada por mulheres tem espaçamento mais regular, com a posição das plantas mais correta e com um padrāo mais homogêneo. Estas características foram sempre destacadas por facilitar toda a condução do mandiocal.

Não é feita adubação química artificial, e os tratos culturais restringem-se à capina executada com maior frequência ( 2 a 3 vezes) nos primeiros meses após o plantio, e poda executada depois de 1 ano, com função bastante específica. A poda é executada para facilitar o processo de fabricação de farinha, pois assim as raízes ficam com menos água, na visão do agricultor: "...se não poda dá mais tiguera...". Segundo os informantes "tiguera" é a água que sai da mandioca no processo de ralamento. 
O número de capinas está diretamente relacionado ao tipo de área escolhida para a roça. Áreas mais antigas do ponto de vista sucessional foram apontadas como as menos laboriosas na execução de capinas. Os resultados das análises laboratoriais do solo coletado nas roças confirmam a baixa fertilidade e a ocorrência de solos arenosos, apropriados ao cultivo da mandioca, Apêndice 2.

As 3 roças deste local têm áreas diferentes, e "donos" diferentes. A roça 1 (0,5ha), é de responsabilidade do membro mais velho (73 anos de idade) da familia. As outras duas são atribuídas a um dos filhos e a um cunhado do membro mais velho. Apesar desta diferenciação, todos os componentes da família participam dos processos de preparo da roça, plantio, colheita, troca e experimentação de novas variedades. Entretanto, tratos culturais, como poda e capina são atribuições de responsabilidade do "dono" da roça.

Destaque deve ser dado à forma métrica utilizada pelos agricultores, como relatado anteriormente por Schmidt (1958). Para calcular a quantidade de mandioca a ser plantada, é utilizado o padrão de "feixes de rama" que, segundo o informante, equivale à quantidade de ramas que podem ser amarradas com uma corda, ou cipó, de tamanho igual a uma braça e dois palmos.

Uma braça equivale ao comprimento dos braços abertos de uma pessoa ( 1,5 metros). Uma roça com 15 feixes de rama de mandioca é considerada grande e de difícil condução, como é o caso da roça 1. Medida semelhante foi encontrada por Schmidt (1958), estudando roças itinerantes na região de Ubatuba (SP). Schmidt encontrou a mesma medida $e$ as mesmas proporções aqui relatadas, entretanto sua designaçāo de "feixe de rama" é menos precisa. Segundo este autor, 
um feixe de rama é "mais ou menos a carga de um homem, isto é, o que um homem suporta carregar à uma determinada distância" ou "feixe que possa lidar com ele, pôr numa canoa, carregar". Em Ariri, as roças dificilmente tem menos de 5 feixes de rama, sendo estimado que podem ser produzidos até 15 sacos de farinha com 6 feixes de rama.

Em Ariri, a área total da propriedade estudada está estimada em 93 ha e um dos informantes calcula que existam capoeiras disponiveis por mais 15 anos. Segundo este informante, depois disso deverão ser usados os locais que hoje são suas roças. A diferenciação dos ambientes para futuras roças é feita através das características fisionômicas da vegetação, da constituição das espécies presentes na área, das características do solo - principalmente no que se refere ao teor de areia - e por características históricas, como as atividades agrícolas dos seus antepassados e as épocas de "maior fartura". Este fato histórico é sempre destacado pelos informantes, e o passado é sempre colocado como mais farto, de maior integração entre famílias, dos grandes mutirões, dos grandes "fandangos" .

\subsubsection{Classes vegetacionais diferenciadas pelo agricultor}

O agricultor fisionomicamente diferencia as áreas em 4 classes, mais contínuas que discretas:

a) Coivara: Porção da floresta onde nunca foi feito roça, considerada "mata virgem" e onde informações históricas locais são importantes na sua diferenciaçāo. As áreas de coivara são consideradas as melhores para plantio principalmente no que diz respeito à noção de

\footnotetext{
${ }^{5}$ festas que acompanhavam a atividade de ajuda entre vizinhos nos mutirões (Queiroz 1983).
} 
produtividade, entretanto são áreas que exigem muita mão de obra familiar.

b) Capoeirāo: Floresta regenerada ou que se apresenta num estágio sucessional entre 15 e 50 anos. Pelo período indicado, a história desta classe vegetacional deve fazer parte da história de vida do próprio agricultor. Tanto numa coivara quanto num capoeirão a derrubada é feita nos meses de dezembro e janeiro, com a primeira queimada em fevereiro e a segunda em junho, sendo o plantio executado em agostosetembro. Não há necessidade de roçada por ocasião do plantio e após ele.

c) Capoeira: Floresta regenerada com até 15 anos de idade. Neste caso, feita a roça, necessita-se de roçadas entre maio e julho antes do plantio. Espécies arbóreas de pequeno porte e grande número de espécies colonizadoras estão presentes, principalmente germinadas do banco de sementes, o que também foi observado por Almeida (1997) e por Misra et al. (1992).

d) Tiguera: Vegetação, ou mesmo uma roça abandonada com não mais de 2 anos. Há necessidade de roçada em maio e julho porém pode-se fazer até mesmo a limpeza, ou derrubada, em julho - agosto seguido da queima, e plantio em setembro.

O uso de "tigueras"b aumentou em função de fatores combinados. Existe a presença intensa de fiscalização florestal, devido à regulamentação da legislação ambiental, que coibe a execução de derrubadas, e existe também o fato da migração para a cidade de

' Mesma designação é dada para a água que sai da mandioca ralada, também conhecida como manipuera. 
membros mais jovens da familia, restringindo atividades que exigem mais mão de obra, como apontaram os informantes. O uso destas áreas modifica as relaçōes de trabalho, a época de preparo da roça, o tempo de utilização, a intensidade de mão de obra dispendida, já que exige maior número de roçadas, e também exige variedades mais adaptadas a condiçōes de menor fertilidade. Além disso ocorrendo migração, o tamanho das familias é menor, o que faz com que se produza menos mandioca para subsistência.

Nestas três últimas classes de vegetação, quando o local fora ocupado por antigas roças, foi observada a presença de plantas de mandioca germinadas a partir de sementes. A mandioca, ao longo do seu processo de domesticação, não perdeu a capacidade reprodutiva via processo sexual. Além de reconhecer fisionomicamente os indivíduos, - agricultor reconhece a planta germinada a partir de semente, por ela estar normalmente fora do arranjamento espacial estabelecido, e por desenvolver raiz pivotante, diferenciando-se das demais.

\subsubsection{Demografia}

Utilizando de quadrados dispostos aleatoriamente dentro das roças, foi possivel estimar densidade, frequência e número de indivíduos por etnovariedade, no ano de 1995 (Ariri 1), Tabela 3. Dentro destas unidades amostrais de $25 \mathrm{~m}^{2}$, cuja quantidade foi diferente para cada roça (de acordo com seu tamanho), o agricultor identificava cada indivíduo existente, nomeando-o (Tabela 3). 
Tabela 3. Unidades amostrais dentro das roças estudadas, no ano de 1995.

\begin{tabular}{|c|c|c|c|c|}
\hline \multirow{30}{*}{$\begin{array}{l}\text { Roça } \\
R 1\end{array}$} & \multirow{3}{*}{$\begin{array}{l}\text { Quadrado }(N)^{*} \\
1(79)\end{array}$} & \multirow{4}{*}{$\begin{array}{l}\text { Etnovariedade } \\
\text { Cascuda } \\
\text { Aipim Roxo } \\
\text { Aipim Manteiga }\end{array}$} & $n^{* *}$ & Frequência (\%) \\
\hline & & & 50 & 63,29 \\
\hline & & & 15 & 18,99 \\
\hline & & & 14 & 17,72 \\
\hline & $2(120)$ & Cascuda & 53 & 44.17 \\
\hline & & Aipim Roxo & 34 & 28.33 \\
\hline & & Aipim Manteiga & 33 & 27.50 \\
\hline & $3(113)$ & Cascuda & 92 & 81,42 \\
\hline & & Aipim Roxo & 13 & 11,50 \\
\hline & & Aipim Manteiga & 8 & 7.08 \\
\hline & $4(104)$ & Cascuda & 36 & 34,62 \\
\hline & & Aipim Roxo & 29 & 27.88 \\
\hline & & Aipim Manteiga & 39 & 37.50 \\
\hline & $5(100)$ & Cascuda & 55 & 55,00 \\
\hline & & Aipim Roxo & 33 & 33,00 \\
\hline & & Aipim Manteiga & 12 & 12,00 \\
\hline & $6(103)$ & Cascuda & 64 & 62.14 \\
\hline & & Aipim Roxo & 34 & 33.01 \\
\hline & & Aipim Manteiga & 5 & .8 .85 \\
\hline & $7(79)$ & Cascuda & 60 & 75,95 \\
\hline & & Aipim Roxo & 9 & 11.39 \\
\hline & & Aipim Manteiga & 10 & 12,66 \\
\hline & $8(88)$ & Cascuda & 51 & 57,95 \\
\hline & & Aipim Roxo & 17 & 19,32 \\
\hline & & Aipim Manteiga & 20 & 22,73 \\
\hline & $9(80)$ & Cascuda & 79 & 98,75 \\
\hline & & Aipim Roxo & $\ldots$ & 1.25 \\
\hline & $10(89)$ & Cascuda & 77 & 86,52 \\
\hline & & Aipim Roxo & 12 & 13,48 \\
\hline & & Total & $955 \mid 3.82 \mathrm{p}$ & antas $/(\mathrm{m} 2)$ \\
\hline \multirow[t]{6}{*}{ R2 } & $1(104)$ & Cascuda & 104 & 100,00 \\
\hline & $2(114)$ & Cascuda & 114 & 100,00 \\
\hline & $3(117)$ & Cascuda & 117 & 100,00 \\
\hline & $4(108)$ & Cascuda & 99 & 91,67 \\
\hline & & Aipim manteiga & 9 & 8,33 \\
\hline & & Total & $443 / 4.43 p$ & antas/m2) \\
\hline \multirow[t]{6}{*}{ R3 } & $1(60)$ & Cascuda & 51 & 85,00 \\
\hline & & Imperial & 9 & 15.00 \\
\hline & $2(104)$ & Cascuda & 103 & 99,04 \\
\hline & & Imperial & 1 & 0,96 \\
\hline & $3(70)$ & Cascuda & 70 & 100.00 \\
\hline & & Total & $234(3.12 f$ & tas $/ \mathrm{m} 2)$ \\
\hline
\end{tabular}

* N=número de indivíduos dentro do quadrado amostral

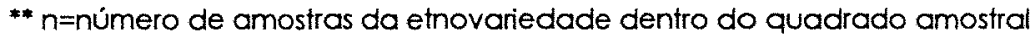


Entre as roças, as densidades absolutas de plantas são muito próximas entre si, Tabela 3, e também bastante altas em comparação à Praia Grande e em comparação à dados encontrados em literatura, (Eden, 1988; Eden, 1993). Foram superiores também à densidade utilizada em plantios comerciais convencionais. No caso da roça 2, a densidade encontrada foi aproximadamente 4,43plantas $/ \mathrm{m}^{2}$, o que se reflete em roças mais adensadas, com menor espaço para outras culturas associadas, menor número de capinas e plantas de pequeno porte na época de colheita. Explicaçōes sobre as razōes de roça mais adensadas do que outras, não foram obtidas com clareza, entretanto a roça 2 foi a única roça cultivada por mulheres. Segundo os informantes, roças plantadas por mulheres, tem espaçamento mais regular e melhor germinação, pelo fato de serem plantadas "com mais cuidado". Provavelmente esta possa ser uma das causas de maior adensamento. já que haveria maior sucesso na germinação, entretanto esta ocorrência não pode ser checada com mais destalhes.

Com relação aos feixes de rama, utilizados como medida padrão para o plantio, observa-se que na roça 1 onde foram plantados 15 feixes de rama, 19100 plantas (Tabela 4). Isso faz com que cada feixe contenha 1273 manivas, que resultarão em indivíduos. Sendo assim, é possivel estimar o número de feixes das outras roças. Na roça 2, com 3323 indivíduos estimatidos, apresenta então 2,6 feixes de rama, e na roça 3, com 6240 individuos estimatimados, tem-se 4,9 feixes. A razão principal, para que a roça 2 esteja fora do limite que os agricultores acreditam ser o ideal, isto é, com não menos de 5 feixes, é função da falta de mão de obra para conduzir uma roça de maior tamanho. 
Tabela 4. Frequência das amostras identificadas dentro dos quadrados amostrais, número estimado para cada etnovariedade dentro da roça. e estimativa total de indivíduos.

\begin{tabular}{llll}
\hline Etnovariedades & Roça 1 & Roça 2 & Roça 3 \\
\hline Cascuda & $64,61 \%(1234))$ & $97.97 \%(3256)$ & $95.73 \%(5974)$ \\
Aipim roxo & $20.63 \%(3940)$ & - & - \\
Aipim manteiga & $14,76 \%(2819)$ & $2,03 \%(67)$ & - \\
Imperial & - & - & $4,27 \%(266)$ \\
\hline $\mathrm{N}^{*}$ estimado & 19100 & 3323 & 6240 \\
Área da roça & $5000 \mathrm{~m}^{2}$ & $750 \mathrm{~m}^{2}$ & $2000 \mathrm{~m}^{2}$ \\
\hline
\end{tabular}

* $N=$ universo total de indivíduos estimado a partir das densidades absolutas observadas.

É notória a predominância da etnovariedade "cascuda" em todas as roças estudadas, sobretudo nas roças 2 e 3 . Tabelas 3 e 4 .

A predominância de uma variedade sobre as outras foi apontada pela vantagem desta na produção de farinha e na sua maior rusticidade. As plantas estavam com altura entre $0,80 \mathrm{~m}$ a $1,0 \mathrm{~m}$ em função do processo de poda ocorrido 6 meses antes.

Nesta primeira coleta ficou claro que 0 informante que acompanhou as coletas na roça identificava com maior facilidade as variedades presentes em maior frequência, sendo que não fazia diferenciação entre "cascudinha" e "cascuda grande" dentro do suposto "grupo cascuda", como ocorreu no ciclo seguinte de coleta, em 1997. com ajuda de outro informante.

\subsubsection{Variedades coletadas para análise, especificidades e origem}

Os locais amostrados estão listados na Tabela 5. Em Ariri 2 (1997), todas as roças re-amostradas são praticamente as mesmas sob o ponto 
de vista geográfico, mas possúem estruturas demográficas diferentes. Quando a agricultor vai formar um nova roça ele usa uma parte da roça antiga para obter manivas, além de poder alterar as proporçōes de indivíduos de cada etnovariedade. As roças 1 e 3 de 1997 foram estabelecidas quase que exclusivamente a partir de manivas da roça 1 de 1995, com a introdução da variedade "mandipóia" (Tabela 6), e a roça 2 de 1997 foi estabelecida a partir da roça 2 de 1995. A roça com menor tempo de uso foi a roça 3 de 1997.

Tabela 5. Locais amostrados.

\begin{tabular}{lllll}
\hline Local & Ano & $\begin{array}{l}\text { Número de roças } \\
\text { (idade) }\end{array}$ & $\begin{array}{l}\text { Total de } \\
\text { variedades }\end{array}$ & $\begin{array}{l}\text { Número de } \\
\text { amostras }\end{array}$ \\
Ariri 1 (Cananéia)* & 1995 & 3 (1 a 4 anos) & 4 & 80 \\
Ariri 2 (Cananéia)* & 1997 & 3 (1 a 6 anos) & 6 & 70 \\
Praia Grande & 1996 & $4(1$ a 3 anos) & 3 & 340 \\
(lporanga) & & & & \\
\hline
\end{tabular}

* Mesma família

No ano de 1997, em Arin, as coletas foram feitas com auxillio do informante mais velho da familia. Ele foi o responsável pela identificação de cada indivíduo amostrado, distintamente da coleta de 1995 onde os indivíduos foram amostrados aleatoriamente, como descrito na metodologia. Em 1995, este informante nāo pôde acompanhar as coletas, indicando na ocasião seu irmão. Em Praia Grande, três informantes pertencentes a familias diferentes, auxiliaram nas coletas. Assim, as hipóteses do trabalho estão centradas no conhecimento detido pela unidade familiar de agricultores.

As variedades coletadas apresentam particularidades culinárias, 
de cultivo e outras (Tabela 6).

Tabela 6. Variedades coletadas e sua particularidades.

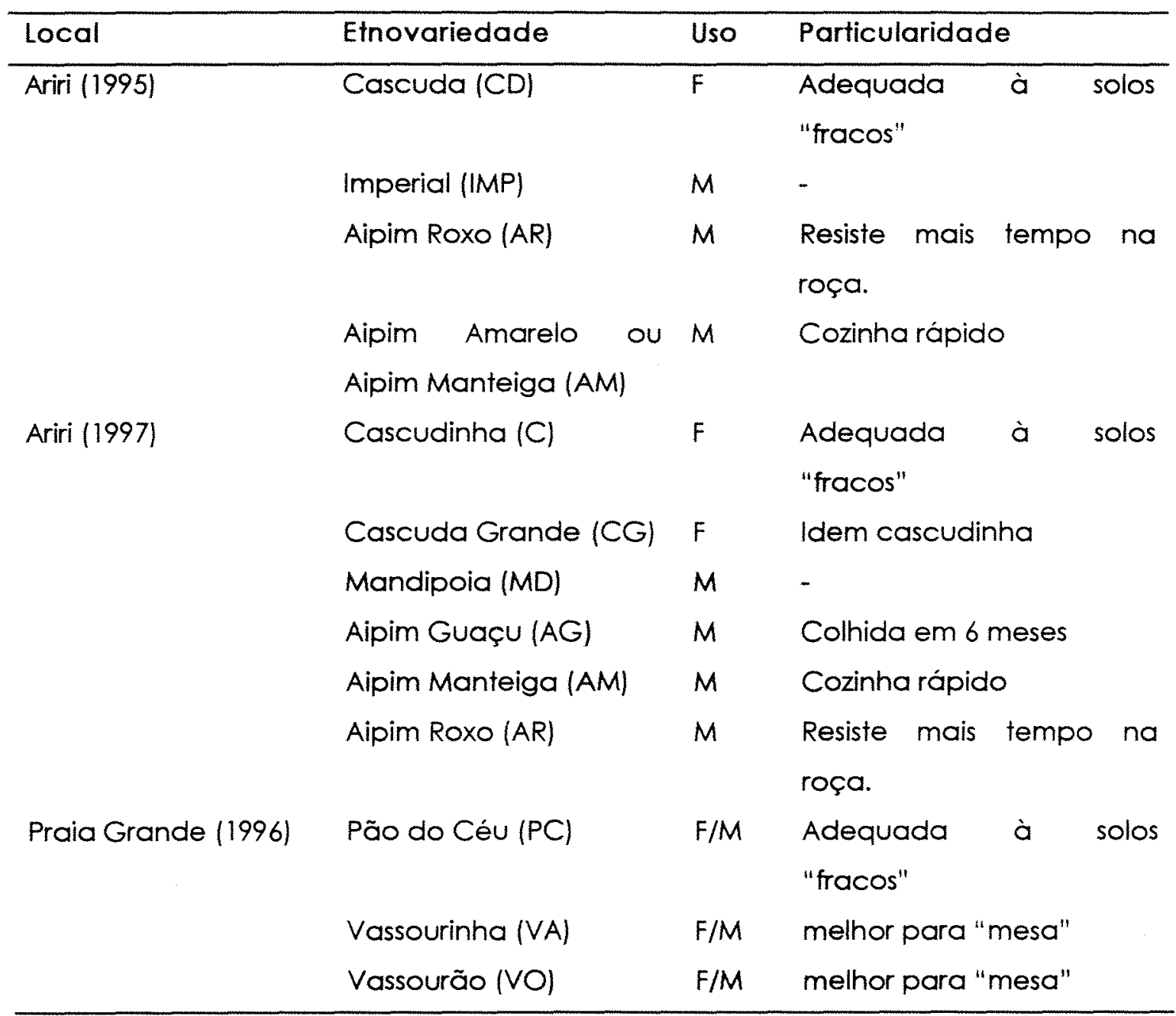

Legenda: F - Farinha: $M$ - Mesa

Para situar historicamente a origem das etnovariedades usadas atualmente, são importantes as informaçōes que dizem respeito à sua obtenção, através de trocas entre comunidades e entre vizinhos, com e sem relações de parentesco. Em Praia Grande, todas as variedades foram citadas como de origem local, porém em Ariri um detalhamento maior foi possivel. 
As variedades utilizadas em Ariri foram obtidas entre os anos de 1989 e 1990, pois antes disso, por razões diversas, a família havia praticamente perdido "a muda" destas variedades que tradicionalmente eram plantadas no local. Esta perda significa o não plantio de roças grandes por um periodo de 2 a 3 anos apenas, e ao buscar novas "mudas" na comunidade, ou na região, o agricultor procura suplantar o baixo número de manivas que tem disponivel para a formação de novas roças.

Assim, a origem das etnovariedades pode ser traçada a partir das informações atuais e resumida da seguinte forma:

- "Cascuda" ("cascudinha" e "cascuda grande") - Proveniente em grande parte da Comunidade de Varadouro’, e em menor proporção dos locais onde as outras foram obtidas

- "Mandipóia" - Fornecidas por um "Compadre", cuja propriedade situa-se a poucos quilômetros de Ariri.

- "Aipim roxo" - Variedade antiga, já pertencia à família

- "Imperial" - Origem desconhecida.

- "Aipim Guaçu" - Proveniente da Comunidade de Varadouro. Obteve a variedade como "aipim cinco minutos", renomeou como "aipim preta" e depois como "aipim guaçu" pois a variedade atinge porte maior que as outras.

- "Aipim manteiga" - Proveniente da Comunidade de Varadouro.

- "Vassourinha" - Proveniente da Comunidade de Varadouro.

Em 1997, o informante relatou que ainda estava "classificando" os

\footnotetext{
${ }^{7} \mathrm{O}$ acesso a esta comunidade leva uma hora de barco, mais duas horas de caminhada por trilha, a partir de Ariri.
} 
individuos dentro das variedades, e separando aqueles que julgava melhores para as roças. Para o informante existia muitas plantas que ele considerava diferente de um padrão para uma determinada etnovariedade, sendo assim, ele poderia não utilizar a "muda" de um individuo diferente para novos plantios. O conceito de seleção ficou bastante evidente pois ele avaliava os individuos, a partir de um critério específico, selecionando-os para formaçāo de novas roças. As caracteristicas utilizadas para classificar os indivíduos dentro de variedades eram conjugadas, semelhante ao relatado por Boster (1984). Segundo o agricultor, os caracteres mais importantes são: forma da folha, cor do peciolo e do caule, forma da raiz, cor da entrecasca da raiz, e cor da polpa raiz, diâmetro relativo do cerne do caule, além da arquitetura da planta, como presença e altura de ramificações. O informante associava estes caracteres à características de preparo da farinha, como facilidade de ralamento: algumas variedades são mais fáceis de ralar pela menor presença de fibras que outras.

Quando classifica um indivíduo, $\bigcirc$ agricultor $\bigcirc$ faz por comparação, de forma a integrar este indivíduo no contexto do "grupo varietal" a que ele pertence, transparecendo um conceito de família de genótipos. Assim o agricultor deve reconhecer uma variedade por características que estão presentes num grupo de indivíduos, ao invés de serem características de apenas um clone, ou um genótipo "tipo" que representaria todo o grupo, ou seja, é um conceito populacional e não individual ou clonal, e requer que as hipóteses evolutivas, relacionadas no modelo de dinâmica evolutiva da mandioca, estejam voltadas para a população que o agricultor maneja, e não para centenas de indivíduos geneticamente idênticos dentro de cada 
etnovariedade. Evidências destas possiveis ocorrências poderōo ser observadas pelas análises dos caracteres morfológicos e isoenzimáticos.

4.2 Análise multivariada. Relaçōes entre etnovariedades e indivíduos, baseadas em dados morfológicos

Os resultados da análises dos caracteres morfológicos serão apresentados separadamente por tipo de amostragem. Portanto, serão colocadas em ítens diferentes as análises feitas sobre as coletas de 1995 , designadas por Ariri1, e de 1997, designadas por Ariri2.

Serão aqui descritos os resultados obtidos a partir dos indivíduos passiveis de avaliação. Como houve perda de parte das amostras (39\%), e da maioria das repetições originalmente coletadas e plantadas, optou-se pela avaliação individualizada. Sendo assim não há repetição e as análises dos caracteres descritos na metodologia serão de caráter exploratório. Portanto, não foi feito qualquer tipo de análise de variância para cada caráter individualmente e o coeficiente de distância escolhido foi distância euclidiana média.

\subsubsection{Distância euclidiana média e agrupamentos}

Serão aqui apresentados os resultados das análises morfológicas da localidade de Ariri, de amostras obtidas nos anos de 1995 (Ariri) e 1997 (Ariri2). No caso de Ariri 1,cada amostra coletada tem uma letra e um número que a identifica. As amostras estão identificadas por $A$, para a roça 1; B. para a roça 2; e C. para a roça 3. Em Ariri 2 e Praia Grande, 
como cada amostra foi identificada pelo agricultor, foi utilizada uma abreviatura do nome etnovarietal dado e um número que a identifica.

Sendo os caracteres de natureza qualitativa e quantitativa, procedeu-se à estandardização dos dados objetivando 0 equacionamento das amplitudes das variáveis. Nos Apêndices 3, 4 e 5, 6 e 7 estão apresentados os valores de distância entre todos os indivíduos para cada roça de Ariri.

No caso de Ariri,l os indivíduos não foram identificados um a um, logo as distâncias mostradas são dos genótipos coletados ao acaso dentro da roça. Como se pode observar pela Tabela 7, a menor média de valores de distância está presente na roça 2 Ariril e o maior valor médio na roça 1 de Ariri2.

Tabela 7. Valores máximos, mínimos e médios das distâncias euclidianas obtidas nas roças estudadas.

\begin{tabular}{llll}
\hline Roça & Valor máximo & Valor mínimo & Valor médio \\
\hline Ar1 R1 & 2,02 & 0.18 & 1.24 \\
Ar1 R2 & 2,34 & 0.17 & 1.04 \\
Ar1 R3 & 2,40 & 0.13 & 1.25 \\
Ar2 R1 & 2,40 & 0.13 & 1.32 \\
Ar2 R3 & 2,01 & 0,28 & 1,26 \\
\hline
\end{tabular}

Em geral, na literatura as avaliações genotípicas, através do uso de caracteres morfológicos, são tradicionalmente feitas entre variedades de mandioca representadas por apenas um clone de cada, e nāo amostras populacionais. Isso torna difícil comparaçōes das 
distâncias obtidas no presente trabalho com dados de literatura. Entretanto, as avaliações de etnovariedades de mandioca feitas por Cury (1993) são comparáveis aos resultados obtidos, já que o autor utilizou praticamente os mesmos caracteres e o mesmo procedimento para cálculo da distância entre genótipos. A magnitude das distâncias obtidas por este autor são equivalentes às distâncias obtidas no presente trabalho, e estão de certa forma em concordância com o esperado para este tipo de coeficiente. Observa-se que para todas as roças estudadas, os valores máximos, minimos e médios são equivalentes entre si. Certas discrepâncias em alguns valores devem ter sido causados pelo fato de haver composição diferenciada de etnovariedades dentro das roças, como ficou evidenciado nos dados demográficos, e por ter sido avaliado números diferentes de amostras em cada roça, no mesmo ano e em anos diferentes.

As relaçōes entre os indivíduos são mais claras quando analisadas na forma de dendrogramas.

4.2.1.1 Análise de Agrupamento das variedades em nível de roça de Ariril

Para os indivíduos amostrados nas roças de Ariril, o que se procurava era uma comparação entre o número grupos observáveis, através análise de agrupamento de individuos avaliados morfologicamente, com o número de variedades que o agricultor conseguia identificar. Como pode ser observado na roça 1 (Figuras $6 \mathrm{e}$ 7). não fica evidenciado claramente quantos grupos são formados 
através dos agrupamentos das amostras. Aparentemente, utilizando UPGMA, Figura 6, não temos conjuntos de indivíduos limitando grupos definidos na roça 1, o que não reflete a identificação local, a qual apontava para 3 variedades pelo menos. Além disso, o número de grupos é diferente em cada método aglomerativo utilizado. Pelo método de Ward (Figura 7) pode ser inferido a presença de cinco grupos: (A05, A15, A22): (A27, A18, A30, A14, A07, A28, A04): (A29, A24, $A 09) ;(A 12, A 13, A 02)$ e (A03, A10, A16, A01). Entretanto, o agrupamento pelo método UPGMA não mostra com clareza nenhum grupo definido, logo inferir sobre grupos, com os agrupamentos obtidos da análise, é uma condição até certo ponto arbitrária.

Assim como na roça 1, em todas as outras roças estudadas os valores de correlação cofenéticos foram mais elevados quando se utilizou o método de UPGMA, Tabela 8. Isso está de acordo com o esperado, $e$ indica que a correspondência entre a matriz de coeficientes originais e $\circ$ dendrograma produzido é melhor representada por este método, principalmente na roça 1 e 3.

Tabela 8. Coeficientes de correlação cofenética obtidos para cada dendrograma apresentado

\begin{tabular}{lll}
\hline Local & UPGMA* $^{*}$ & Ward** \\
\hline Ariril-Roça 1 & 0,8719 & 0,6946 \\
Ariril - Roça 2 & 0,9827 & 0,9597 \\
Ariril - Roça 3 & 0,8669 & 0,6564
\end{tabular}

* Coeficiente de correlação cofenético obtido através de agrupamento utilizando UPGMA

** Coeficiente de correlação cofenético obtido através de agrupamento utilizando método de Ward. 
Na roça 2 (Figuras 8 e 9), os agrupamentos são melhores que os obtidos na roça 1. Nesta roça, o agricultor diferenciava 2 variedades e pelo agrupamento obtido pelo método de UPGMA (Figura 8) parecem existir três grupos, se for considerado os indivíduos B48 e B42, como representantes de grupos e todos os outros indivíduos como representantes de um terceiro grupo maior. Novamente para esta roça há dúvidas para se eleger o número de grupos correto pois há mudanças da posiçāo dos individuos quando se muda o método aglomerativo. Pelo método de Ward (Figura 9) observa-se uma estrutura diferente da obtida pelo método de UPGMA. Apesar disto, os valores de correlação cofenéticos, obtidos para ambos os métodos aglomerativos, são elevados, e no caso desta roça tem-se um pouco mais de segurança para se eleger três grupos citados acima. As Figuras 10 e 11 , que representam os dados da roça 3, apontam para o mesmo problema, sendo difícil a decisão sobre o número de grupos resgatados pela análise. Pela identificaçāo local a roça 3 deveria apresentar três etnovariedades, isto é, três grupos, definidos e distintos, entretanto não se pode afirmar a presença destes agrupamentos com certeza, se observamos as análises de agrupamento obtidas. 
Dendrograma para as amostras de Ariri 1 roça 1

UPGMA

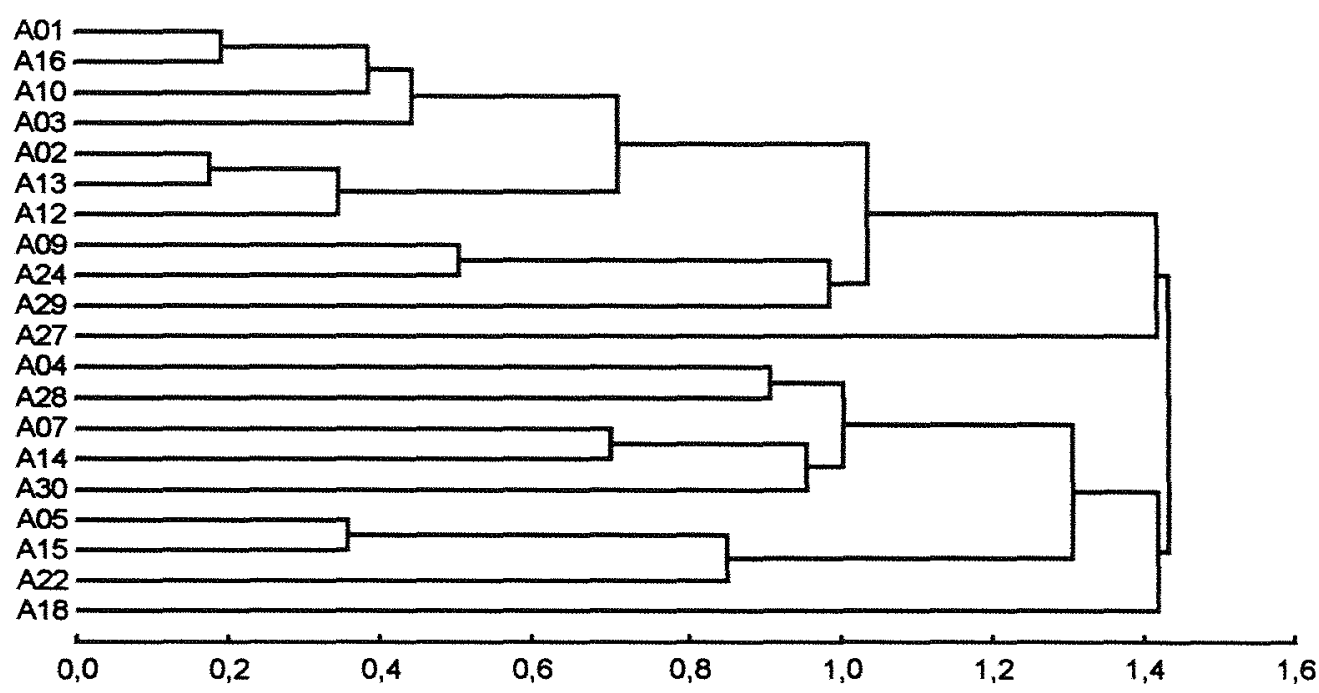

Figura 6. Agrupamento, pelo método de UPGMA, das vinte amostras de etnovariedades de mandioca de Ariri 1, roça 1.

Dendrograma para as amostras de Ariri 1 roça 1

Método de Ward

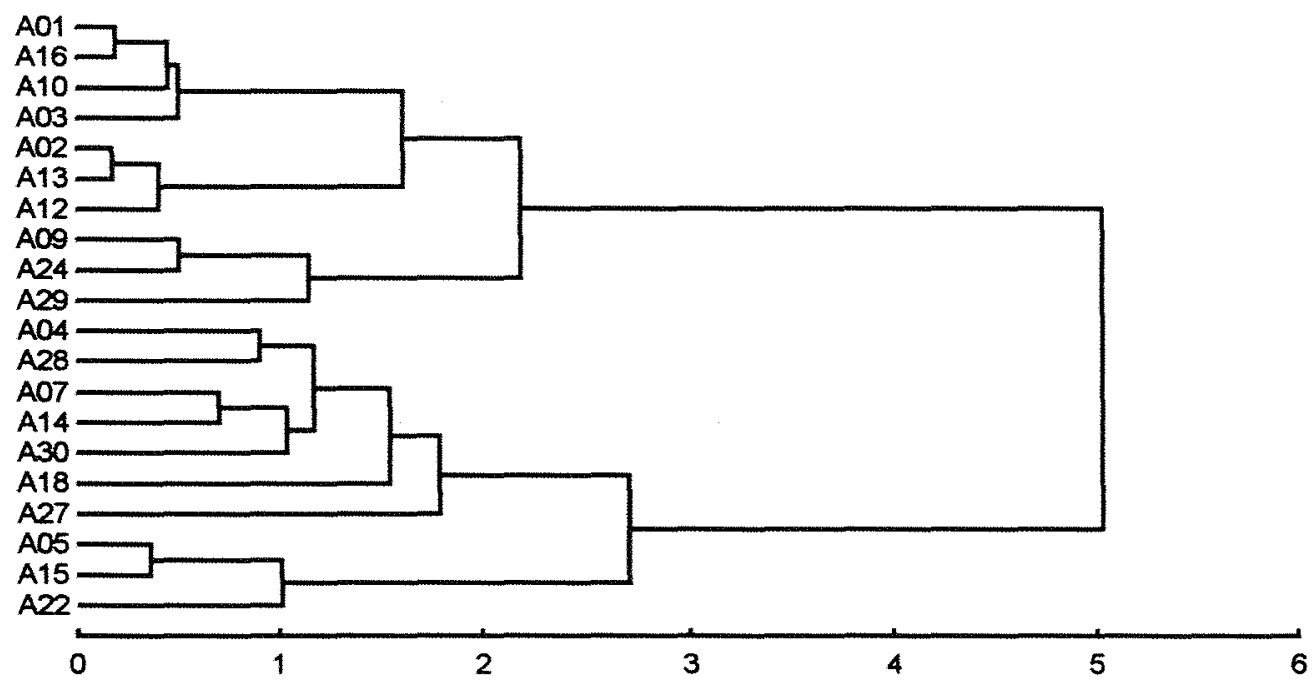

Figura 7. Agrupamento, pelo método de Ward, das vinte amostras de etnovariedades de mandioca de Ariri 1, roça 1. 
Dendrograma para as amostras de Ariri1 roça2 UPGMA

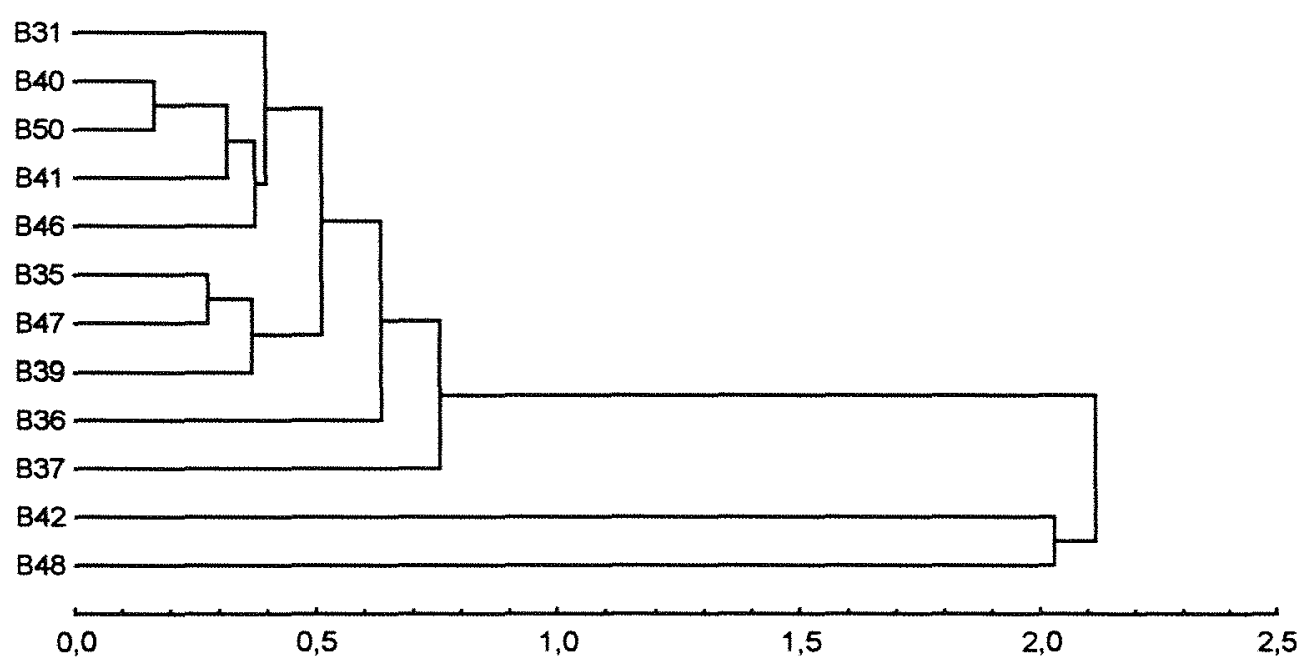

Figura 8. Agrupamento, pelo método de UPGMA, das 12 amostras de etnovariedades de mandioca de Ariri 1, roça 2.

Dendrograma para as amostras de Ariri 1 roça 2 Método de Ward

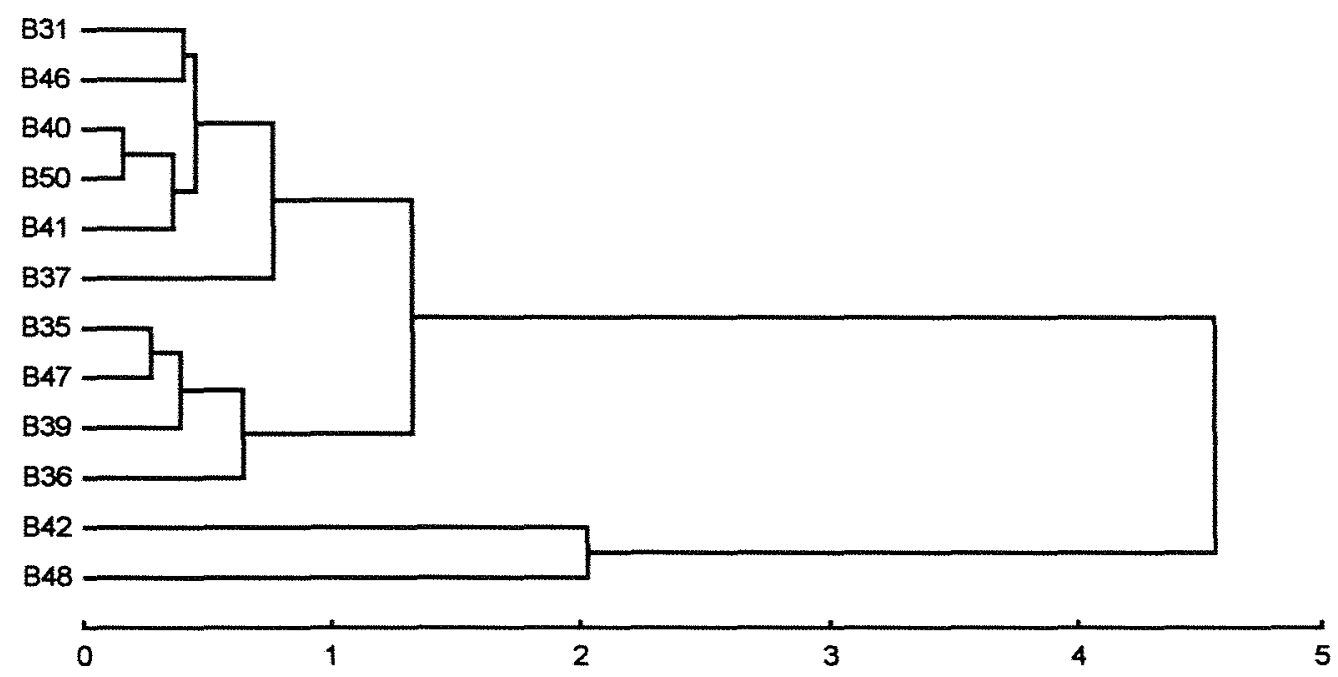

Figura 9. Agrupamento, pelo método de Ward, das 12 amostras de etnovariedades de mandioca de Ariri 1, roça 2. 
Dendrograma para as amostras de Ariri1 roça3

UPGMA

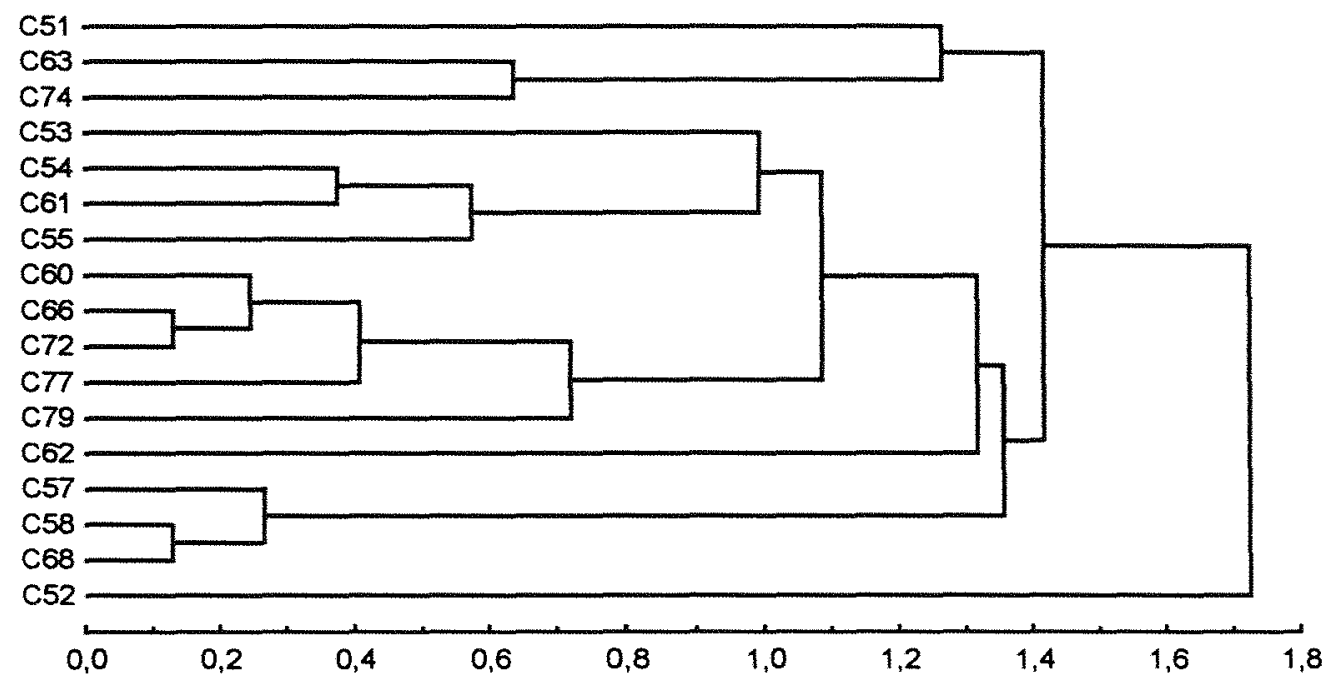

Figura 10. Agrupamento, pelo método de UPGMA, das 17 amostras de etnovariedades de mandioca de Ariri 1, roça 3.

Dendrograma para as amostras de Ariri 1 roça 3

Método de Ward

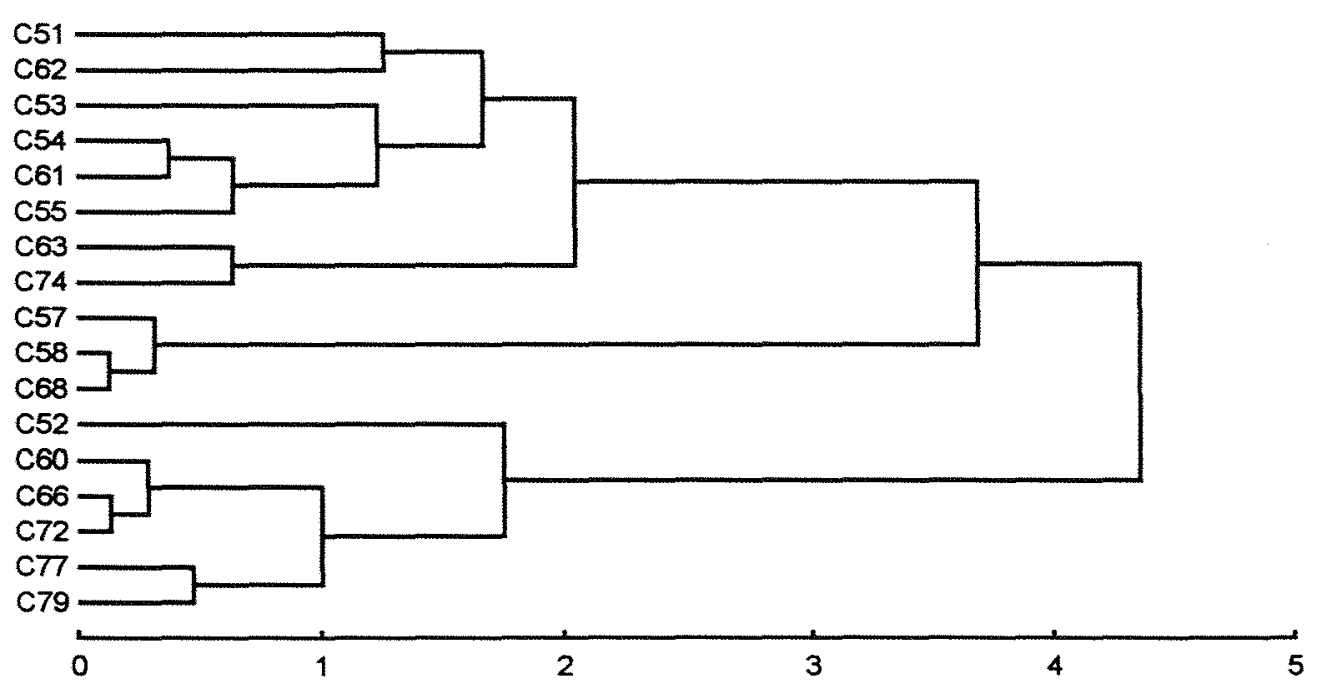

Figura 11. Agrupamento, pelo método de Ward, das 17 amostras de etnovariedades de mandioca de Ariri 1, roça 3. 
Todos os agrupamentos de Ariril mostraram modificações, ou trocas de ligações, quando se mudou o método aglomerativo. Isso indica uma certa falta de estrutura dos dados, não havendo como definir os grupos coerentemente, principalmente para as roças 1 e 3 . Entretanto, a nāo identificaçāo de grupos é agravada pelo fato desta amostragem ter sido feita sem nomeação das amostras. Isso impede que se visualize claramente mudanças de agrupamento de um individuo pertencente à uma determinada etnovariedade para outra etnovariedade. Visualmente, nestas roças, as etnovariedades eram muito semelhantes entre si quanto a morfologia, e a hipoteticamente pode-se inferir, que devido à continuidade existente nos caracteres avaliados, tenha ocorrido a falta de estruturação observada. Temos que lembrar que estas avaliaçōes de morfologia são de um número pequeno de etnovariedades por roça, e que na amostragem pode ter sido pegas amostras de praticamente uma etnovariedade. Essa falta de estrutura então seria reflexo praticamente da variação ambiental a que os indivíduos de uma mesma etnovariedade estariam sujeitos, prejudicando a diferenciação de grupos bem definidos.

Apesar dos caracteres terem sido avaliados em condições experimentais, onde se supōe que as variações devidas ao acaso sejam menores, a análise de agrupamento para estas roças não é muito útil na diferenciação de grupos.

Na segunda coleta, em 1997 (Ariri2), o agricultor fez a identificação de cada indivíduo amostrado, temos então uma informação muito mais precisa do ponto de vista da identificação, permitindo visualizar com mais detalhes as relaçōes entre subgrupos e 
grupos de variedades. Além disso, existe melhor estruturação dos grupos avaliados que os de Ariril, apesar dos dados terem sido obtidos de individuos nas roças, isto é, "in situ".

4.2.1 .2 Análise de Agrupamento das variedades em nivel de roça de Ariri2

\subsection{Roça 1}

Os três métodos utilizados resgatam os grupos, havendo modificaçōes em algumas das amostras, como para os indivíduos MD2, MD7 e MD12, no método de Ward (Figura 13), que se diferenciam de UPGMA (Figura 12) e Ligação simples (Figura 14), e o indivíduo CGl que situado mais proximamente do grupo das "cascudas grandes" em UPGMA, passa a uma posição mais "externa" com Ligação Simples. O indivíduo AM30 também se aproximou do grupo das "cascudas grandes" (CG), através do método de Ward (Figura 13). Outras mudanças ocorreram em nível de subgrupos como para os indivíduos C17 e C8, não havendo trocas entre grupos. O grupo dos "aipim guaçu" (AG) como um grupo à parte em UPGMA juntou-se ao grupo das "cascudas grandes" (CG) e "mandipoia" (MD) com Ward (Figura 13). 


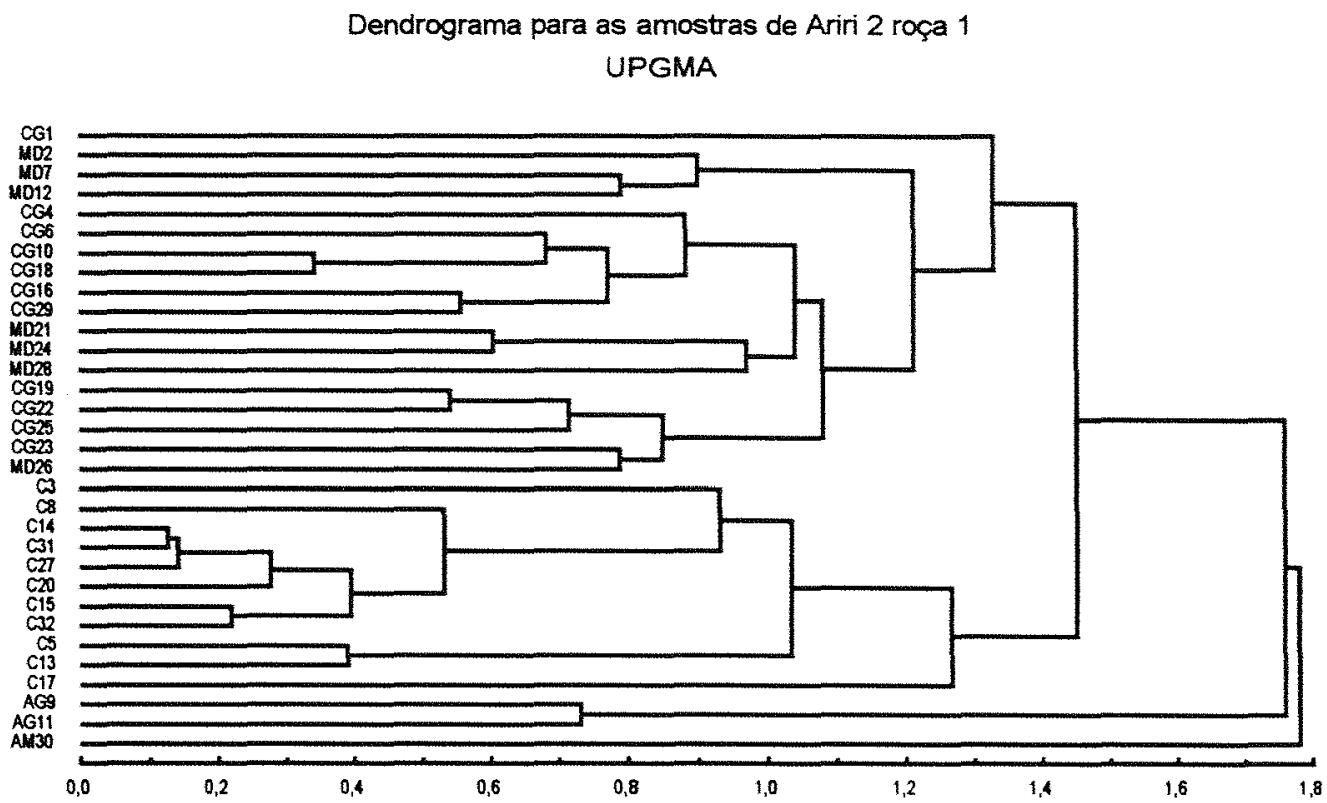

Figura 12. Agrupamento, pelo método de UPGMA, das 32 amostras de etnovariedades de mandioca de Arin 2 , roça 1.

Dendrograma para as amostras de Ariri 2 roça 1

Método de Ward

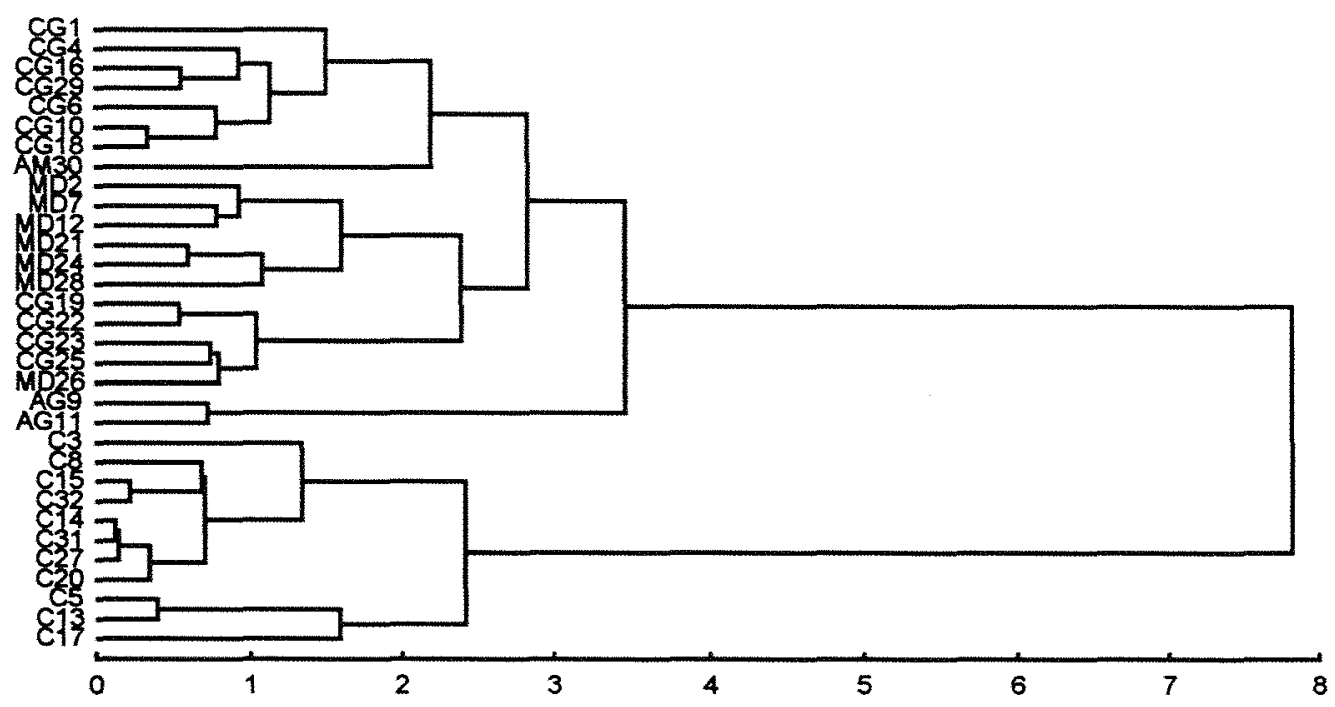

Figura 13. Agrupamento, pelo método de Ward, das amostras de etnovariedades de mandioca de Ariri 2 , roça 1. 
Dendrograma para as amostras de Ariri 2 roça 1

Método de Ligaçäo Simples

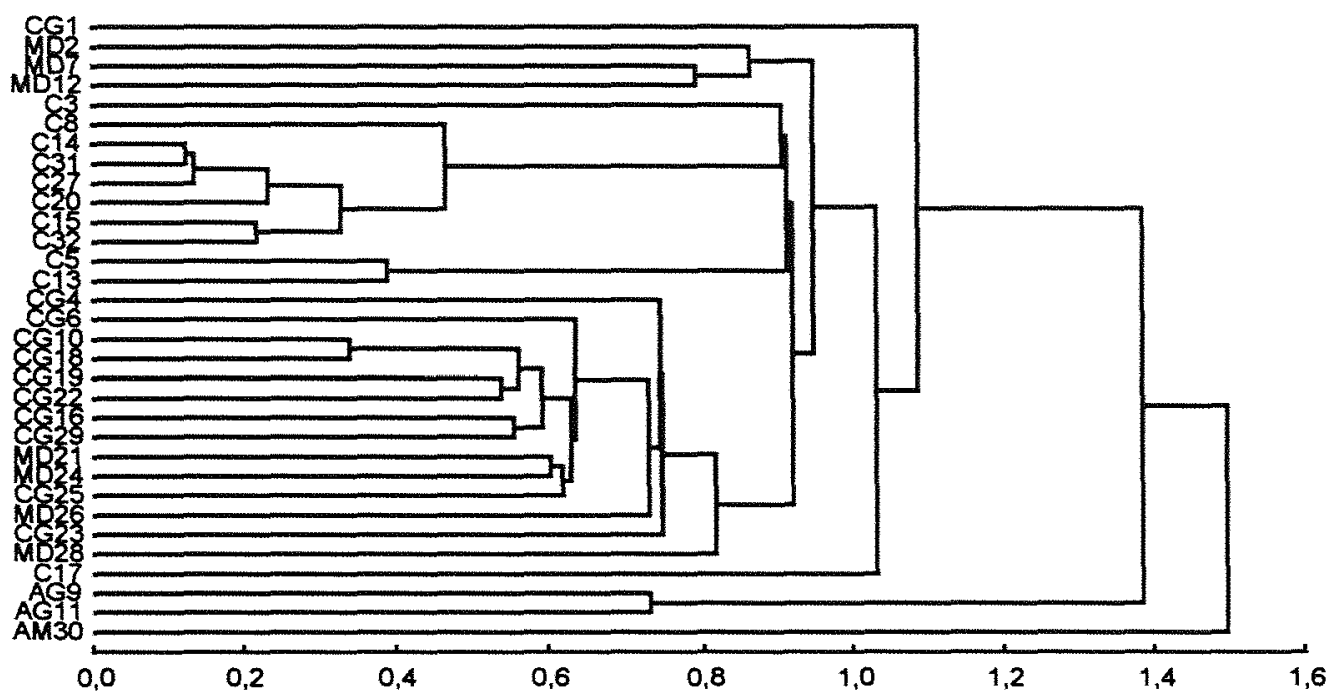

Figura 14. Agrupamento, pelo método de Ligaçāo Simples, das amostras de etnovariedades de mandioca de Ariri 2,roça 1.

Para uma comparação mais ampla, optou-se pela inclusão da análise utilizando o método aglomerativo "Vizinho mais próximo" (Ligação simples), que além de ser bastante difundido na literatura, permite detectar variação clinal entre grupos (Sneath \& Sokal, 1973) representando mais uma comparação sobre a existência de estrutura nos dados avaliados.

Observa-se que para esta roça, os dados não refletem muito bem as relações de proximidade e/ou distanciamento entre grupos de etnovariedades, mas refletem adequadamente a presença de alguma estrutura dos grupos, ou seja, observa-se que existe o grupo das "cascudinhas", o grupo das "cascudas grandes", dos "aipim guaçu", e o grupo das "aipim manteiga". Apesar disto, os métodos UPGMA (Figura 12) e Ward (Figura 13) indicam a presença de dois subgrupos de 
"cascuda grande" e dois subgrupos de "mandipóia". Isto parece estar relacionado a variação ambiental que estes indivíduos estão sujeitos. Pela numeração das amostras podemos ver que MD2, MD7 e MD12, assim como MD21, MD24 e MD 28 (Figura 12) estão localizados próximos uns dos outros, indicando que possivelmente existiu algum fator ambiental específico para o local onde estas amostras foram avaliadas e que influenciou a estimativa dos caracteres quantitativos avaliados. Isso pode estar ocorrendo também com os dois subgrupos de "cascuda grande", que apresentam indivíduos localizados próximos uns dos outros em cada subgrupo.

O método do Vizinho mais próximo refletiu , ou indica, nesta roça, a variação contínua existente e/ou a falta de estrutura bem definida que existe dentro de um suposto grupo maior, compostos pelos subgrupos "mandipóia" (MD) e "cascudas grandes" (CG) (Figura 14). Apesar disso, podemos inferir sobre a presença destes grupos quando comparamos com os dados da roça 3 a seguir.

Fica claro na roça 1 que existem grupos distintos mas as relações fenéticas não são tão óbvias assim. O fato destas observações terem sido geradas por dados obtidos in situ, devendo haver variação devida ao acaso, deve ter influenciado as mudanças de subgrupos observadas. Entretanto é este o panorama com que o agricultor se depara e no qual consegue identificar suas variedades, refletindo melhor a realidade observada do que dados de amostras plantadas e avaliadas em condiçōes homogêneas ou experimentais.

Para roça 1, apesar da correlação cofenética para Ward não ter sido muito elevada (Tabela 9), obteve-se a melhor representação dos grupos. Logo a integração de métodos aglomerativos foi bastante útil 
para destacar aspectos diferentes dos dados. Se fosse utilizado apenas um método, como o de UPGMA, seria uma opção arbitrária, já que observa-se pequenas mudanças entre métodos. Para a roça 3 obtevese valores maiores de correlação cofenética para os dois métodos aglomerativos utilizados (Tabela 9) e as representaçōes dos grupos é melhor destacada.

Tabela 9. Coeficientes de correlação obtidos para cada dendrograma apresentado

\begin{tabular}{llll}
\hline Local & UPGMA* $^{*}$ & Ward $^{* *}$ & Lig. Simples*** \\
\hline Ariri2 - Roça 1 & 0,8438 & 0,5453 & 0,7876 \\
Ariri2 - Roça 3 & 0,9255 & 0,8243 & - \\
\hline
\end{tabular}

* Coeficiente de correlação cofenético obtido através de agrupamento utilizando UPGMA

** Coeficiente de correlação cofenético obtido através de agrupamento utilizando método de Ward.

*** Coeficiente de correlação cofenético obtido através de agrupamento utilizando método de Ligação simples

\subsection{Roça 3}

Cabe lembrar que não foi possivel avaliar os caracteres mofológicos dos indivíduos amostrados da roça 2 de Ariri2.

No caso da roça 3 de Ariri2 os valores de correlação cofenética (Tabela 8) são altos e as proximidades morfológicas entre grupos podem ser inferidas com maior segurança. Além disso os dois métodos, UPGMA e Ward, recuperaram a mesma estrutura em relaçāo às etnovariedades. Os agrupamentos obtidos indicam a presença de grupos de amostras 
compondo etnovariedades com coerência na morfologia. Esta roça é de menor tamanho que a roça 1 e visualmente apresentava-se muito mais homogênea quanto a altura dos indivíduos e a sua distribuição. Estes fatores podem ter sido mais favoráveis para a caracterização morfológica do que na roça 1.

Observa-se que "aipim guaçu" (AG) neste caso junta-se do grupo das "cascudas grandes" (CG) em ambos os agrupamentos, e que existe maiores semelhanças entre "mandipoia"(MD), "aipim guaçU"(AG) e "cascuda grande" (CG), que esta última com "cascudinha"( C), Figuras 15 e 16.

Dendrograma para as amostras de Ariri 2 roça 3

UPGMA

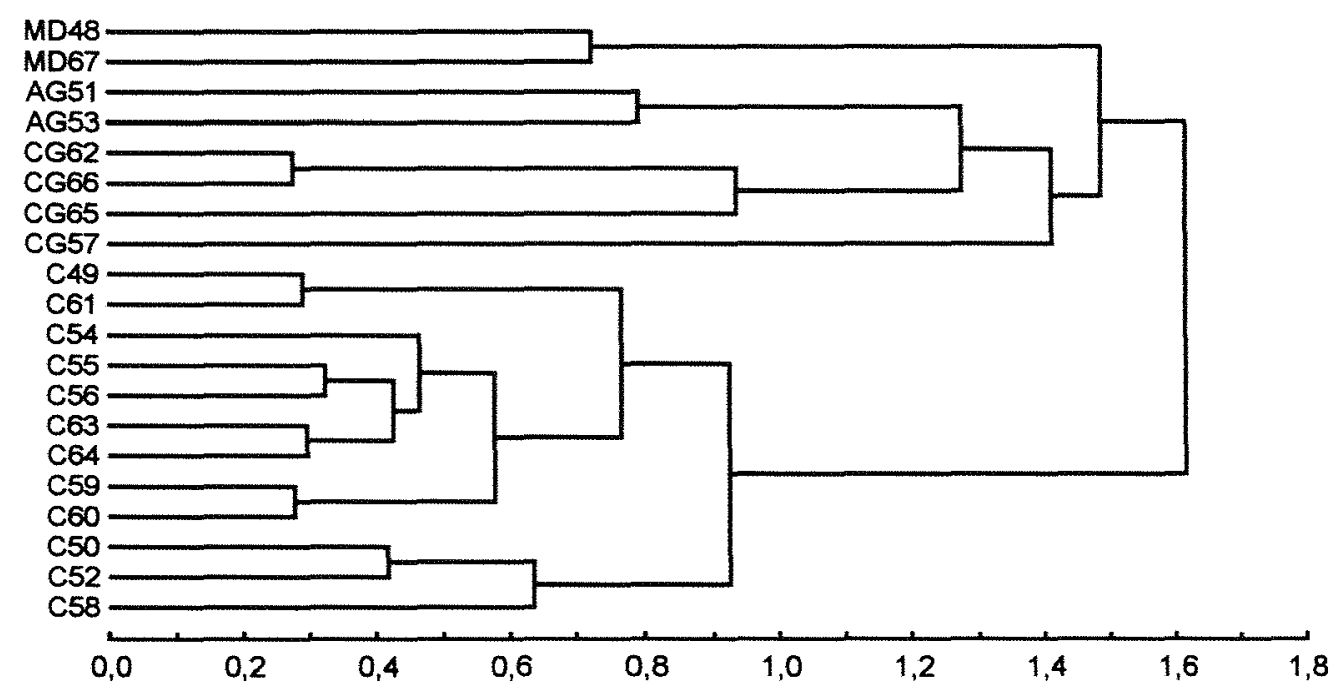

Figura 15. Agrupamento, pelo método de UPGMA, das amostras de etnovariedades de mandioca de Ariri 2 , roça 3. 
Dendrograma para as amostras de Ariri 2 roça 3

Método de Ward

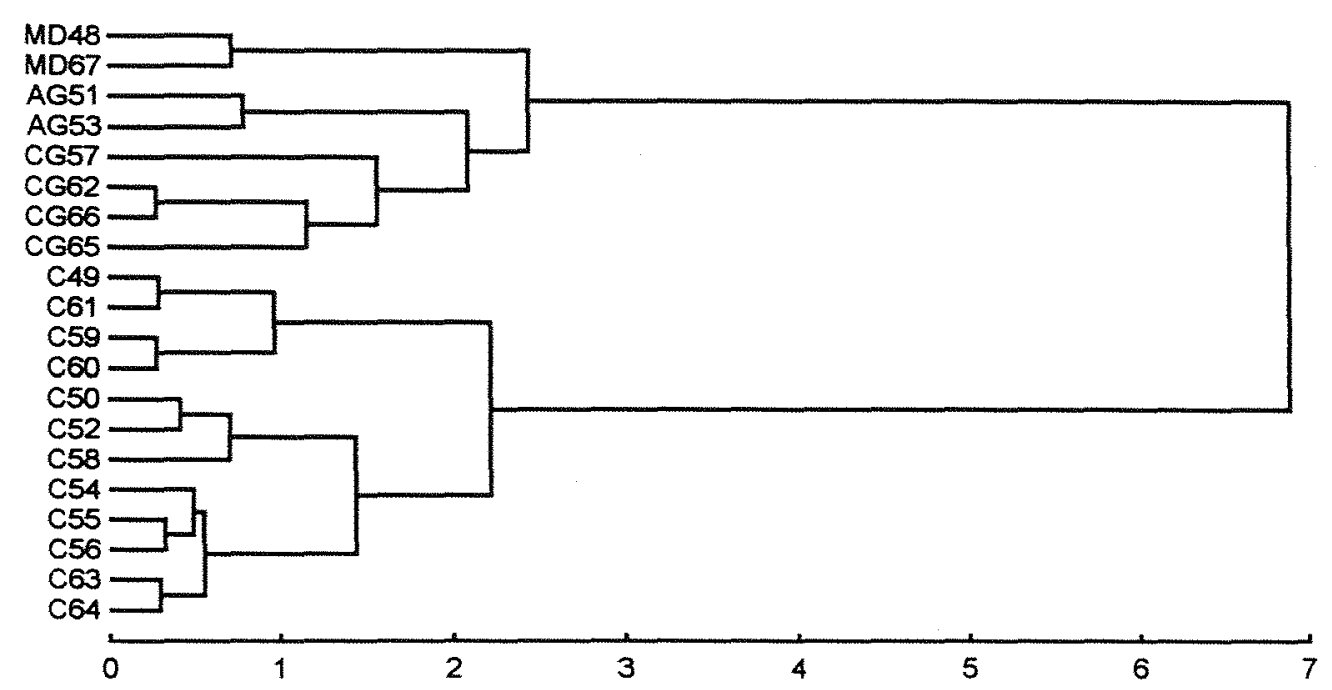

Figura 16. Agrupamento, pelo método de Ward, das 20 amostras de etnovariedades de mandioca de Ariri 2 , roça 3.

Nesta roça observamos com mais clareza a diferenciação de etnovariedades, formando grupos definidos. Não foi encontrado em literatura estudos que avaliem indivíduos amostrados como uma população, logo não foi possível comparar estes resultados, entretanto autores que avaliaram mofologicamente etnovariedades de mandioca encontram diferenciação entre elas, refletindo a diferenciação observada pelo agricultor que as identifica (Cury, 1993).

No caso das amostras estudadas, observa-se que os indivíduos dentro de cada grupo são muito semelhantes entre si, formando agrupamentos distintos.

Comparando os cinco agrupamentos obtidos destas 2 roças, fica evidente, que o agricultor é preciso na identificação de suas variedades em nivel de grupo, principalmente quanto as amostras da roça 3. Estes 
resultados indicam ainda que as etnovariedades são grupos morfologicamente distintos e que existe coerência na identificação feita pelo agricultor. Para este conjunto de amostras o método de agrupamento foi bastante útil para explicitar a coerência entre o que é identificado com o que é obtido pela análise dos caracteres morfológicos.

Para uma discussão mais pormenorizada dos grupos formados e da influência dos caracteres avaliados é de grande utilidade a interpretaçāo dos resultados obtidos pelas análises de ordenação. 


\subsubsection{Análise de correlação entre variáveis}

Como passo precedente às análises de ordenação, foram executadas análises das correlações de Spearman entre todas as amostras, par a par, para cada roça estudada. Como entre os descritores existem variáveis discretas e contínuas, não foi feito teste de significância.

Pode-se observar que as correlações entre variáveis são altas para muitos dos caracteres estudados em todas as roças avaliadas, Apêndices $8,9,10,11$ e 12. Estes valores justificam o uso de análise multivariada para os caracteres em questão.

\subsubsection{Análise de Componentes Principais (PCA)}

Os Apêndices 13, 14, 15, 16 e 17 mostram os autovalores e as proporções da variância total representadas para cada componente, para as roças 1, 2 e 3 de Ariri 1 e roças 1 e 3 de Ariri 2, respectivamente. A extração dos componentes foi realizada sob a matriz de dados estandardizados e utilizando matriz de covariância. É sabido que utilizando a matriz de dados originais sem transformação, combinada à matriz de correlação, os resultados serão os mesmos, entretanto optouse pela matriz de covariância, pela facilidade de manejo de planilhas de dados e uso de pacotes estatísticos.

Utilizando matriz de covariância, foram eliminadas aquelas variáveis que para o conjunto de amostras apresentavam desvio 
padrāo, ou variância, igual a zero. Para as roças de Ariril as variáveis eliminadas para a roça 1 foram: CBF, SLF, e PCF; para a roça 2 foram: SLF, e PCF; para a roça 3 foram: SLF, e PCF. Para as roças de Ariri 2 as variáveis eliminadas foram: SLF, para a roça 1 e SLF e CPO para a roça 3.

Pelos resultados obtidos observa-se que a análise foi bastante satisfatória para as três roças analisadas em Ariril, principalmente para a roça 2 , chegando a $86,96 \%$ de variância acumulada nos dois primeiros componentes ou eixos principais (Apêndice 14). Desta forma podemos representar graficamente os escores obtidos para cada amostra, para cada roça.

Para as roças 1 e 3 o uso de apenas 2 componentes representa apenas $52.79 \%$ (Figuras 17 e 18) e 64,62\% (Figuras 22 e 23) respectivamente da variância total, portanto optou-se também pela representação tridimensional dos 3 primeiros componentes, a fim de representar $69,20 \%$ da variação para a roça 1 e $77,79 \%$ para a roça 3 (Figuras 19 e 24). Para a roça 2 foram usados apenas os dois primeiros componentes, representando $86,96 \%$ da variação total (Figuras 20 e 21). 


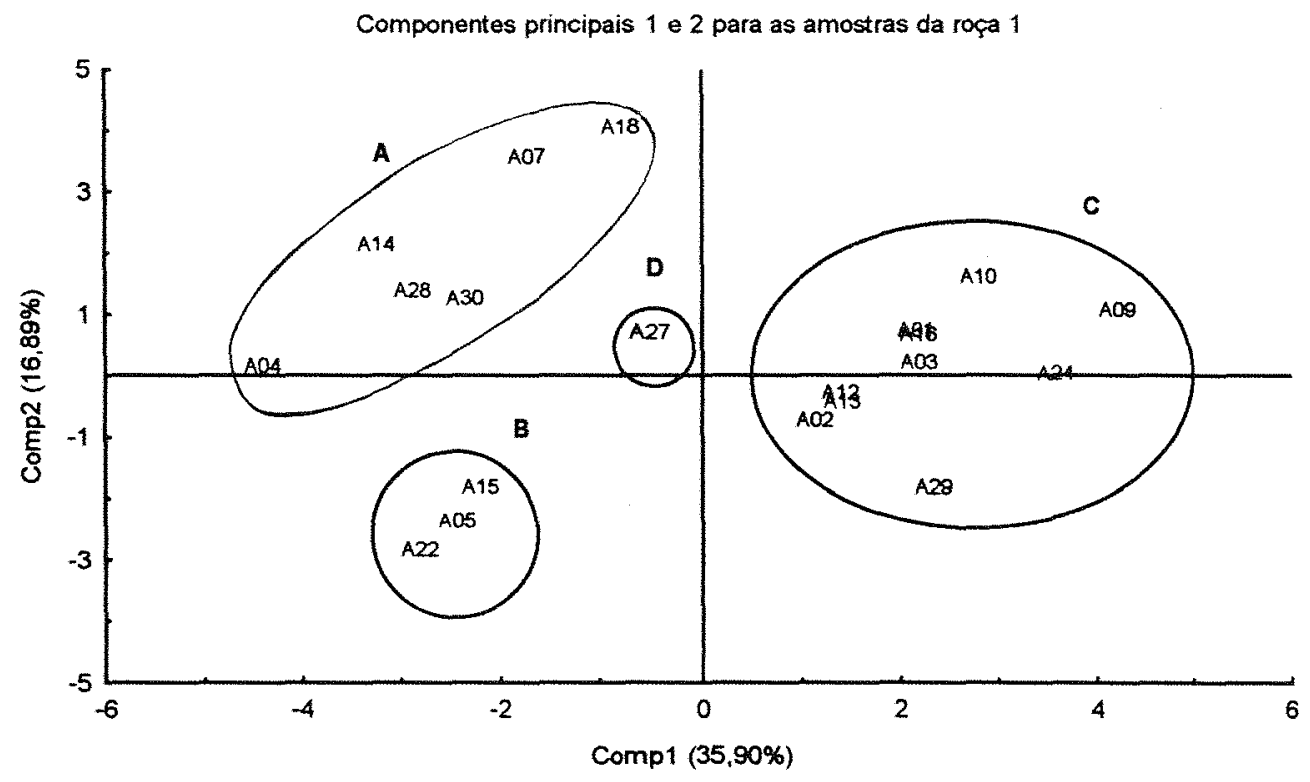

Figura 17. Escores provenientes da análise de componentes principais entre amostras de etnovariedades de mandioca de Ariri 1, roça 1, considerando os componentes 1 e 2 .

Componentes principais 1 e 2 para as amostras da roça 1

Variáveis

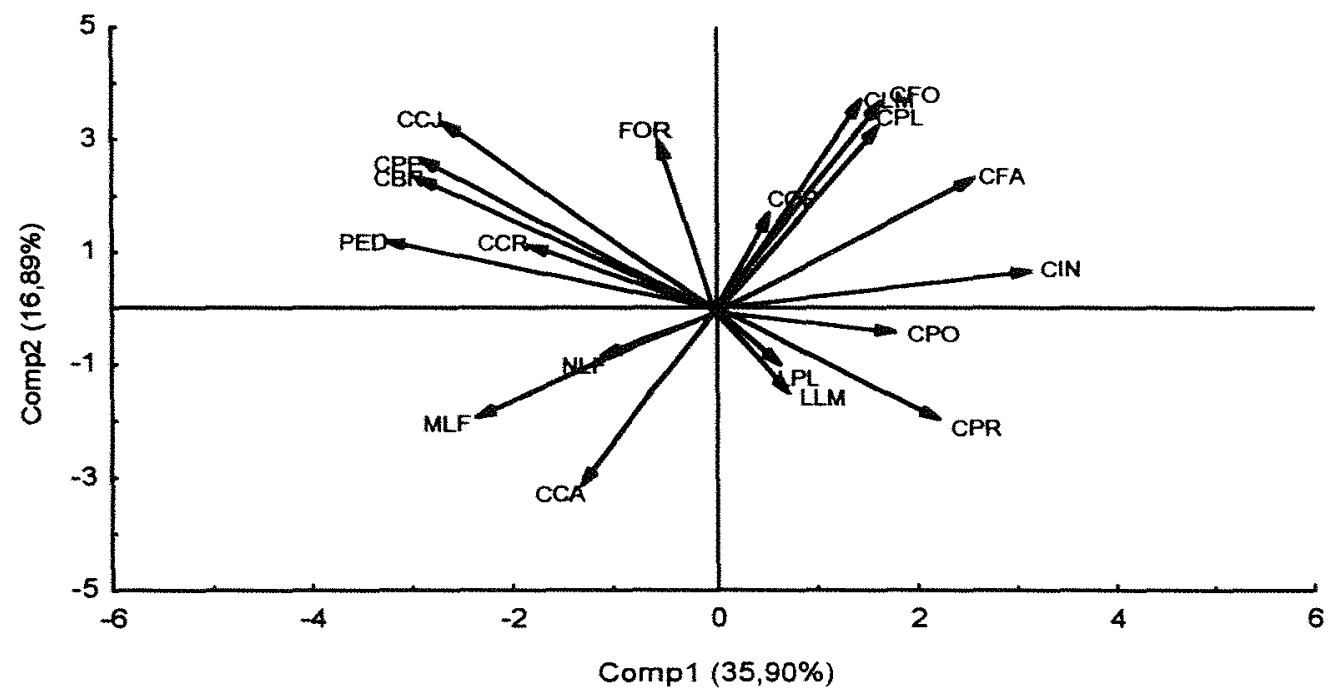

Figura 18. Contribuição das variáveis originais para os componentes principais 1 e 2 entre as amostras de etnovariedades de mandioca de Ariri 1, roça 1. 
Componentes 12 e 3 para as amostras da roça 1

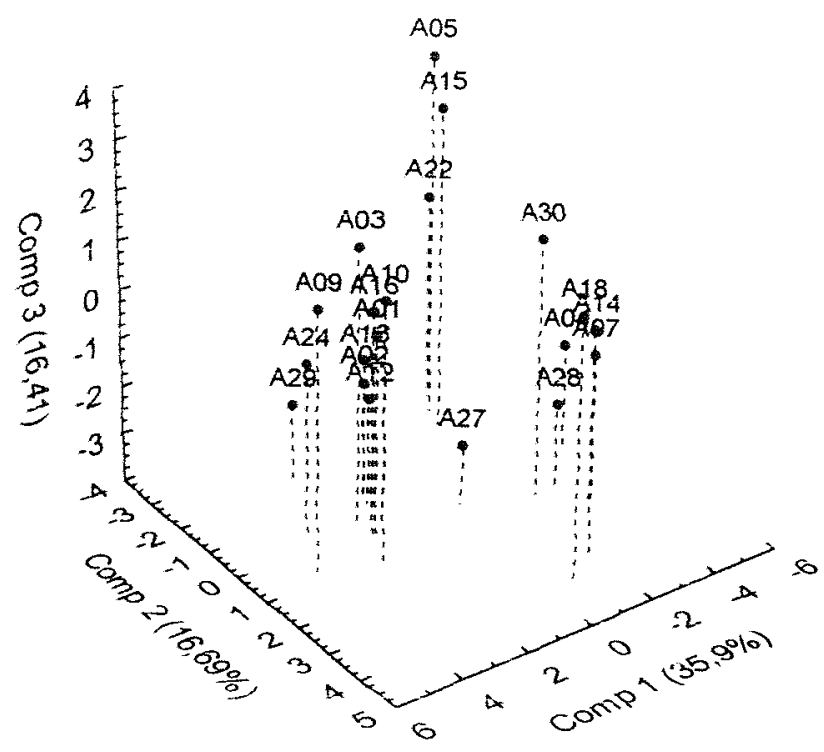

Figura 19. Escores provenientes da análise de componentes principais entre amostras de etnovariedades de mandioca de Ariri 1, roça 1 . considerando os componentes 1, 2 e 3.

Componentes principais 1 e 2 para as amostras da roça 2

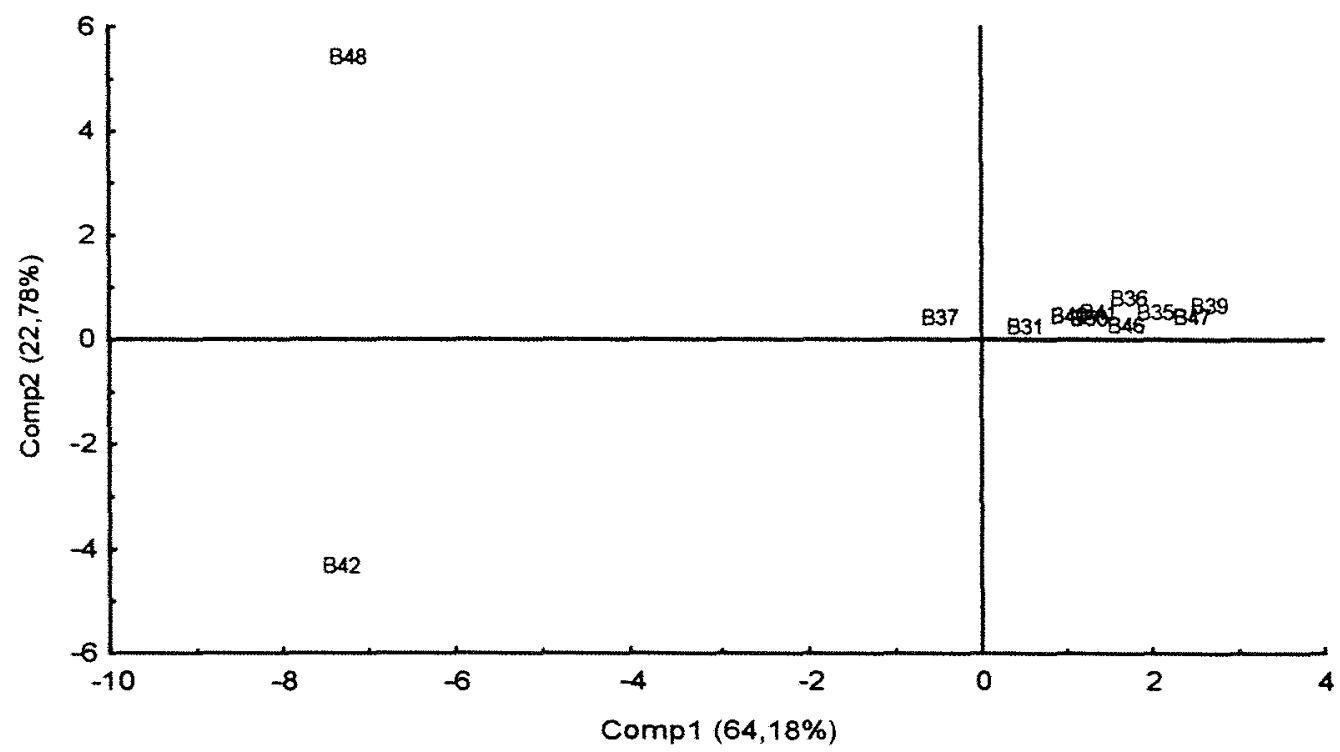

Figura 20. Escores provenientes da análise de componentes principais entre amostras de etnovariedades de mandioca de Ariri 1, roça 2 , considerando os componentes 1 e 2. 
Componentes principais 1 e 2 para as amostras da roça 2

Variáveis

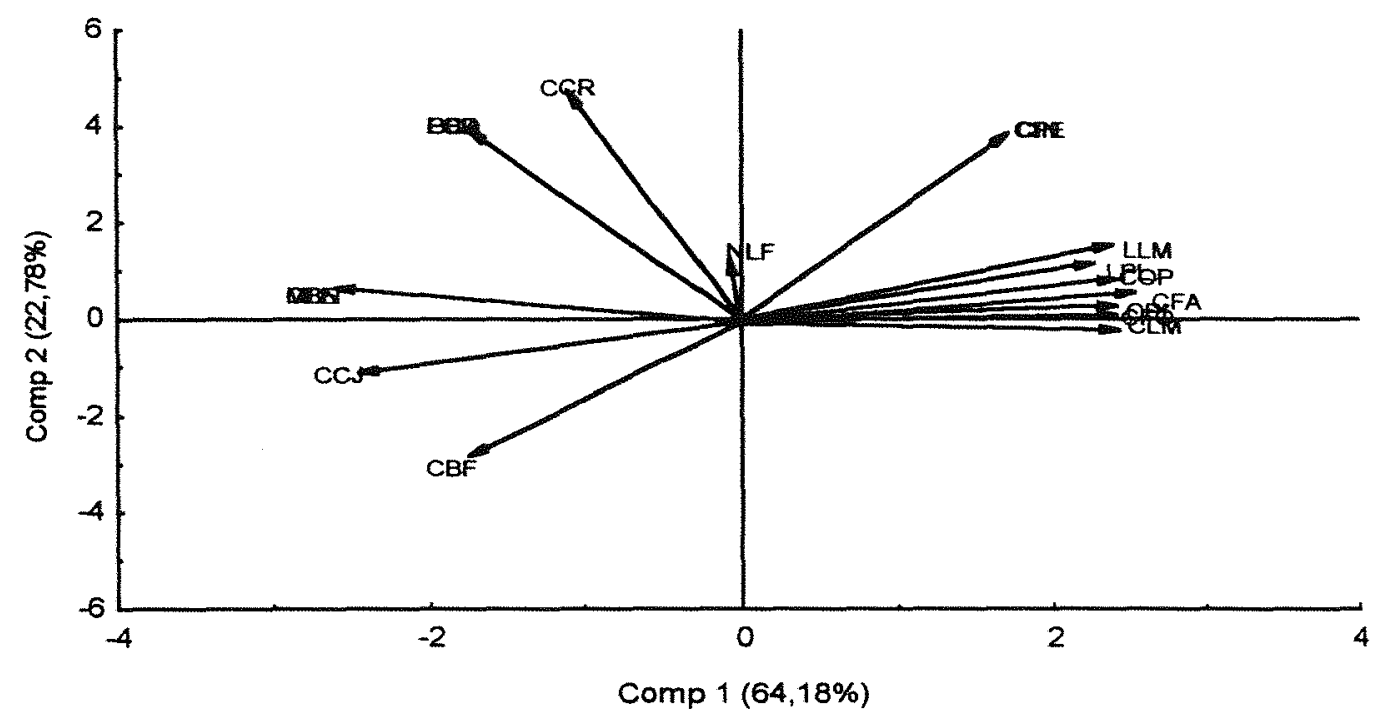

Figura 21. Contribuição das variáveis originais para os componentes principais 1 e 2 entre as amostras de etnovariedades de mandioca de Ariri 1, roça 2.

Componentes principais 1 e 2 para as amostras da roça 3

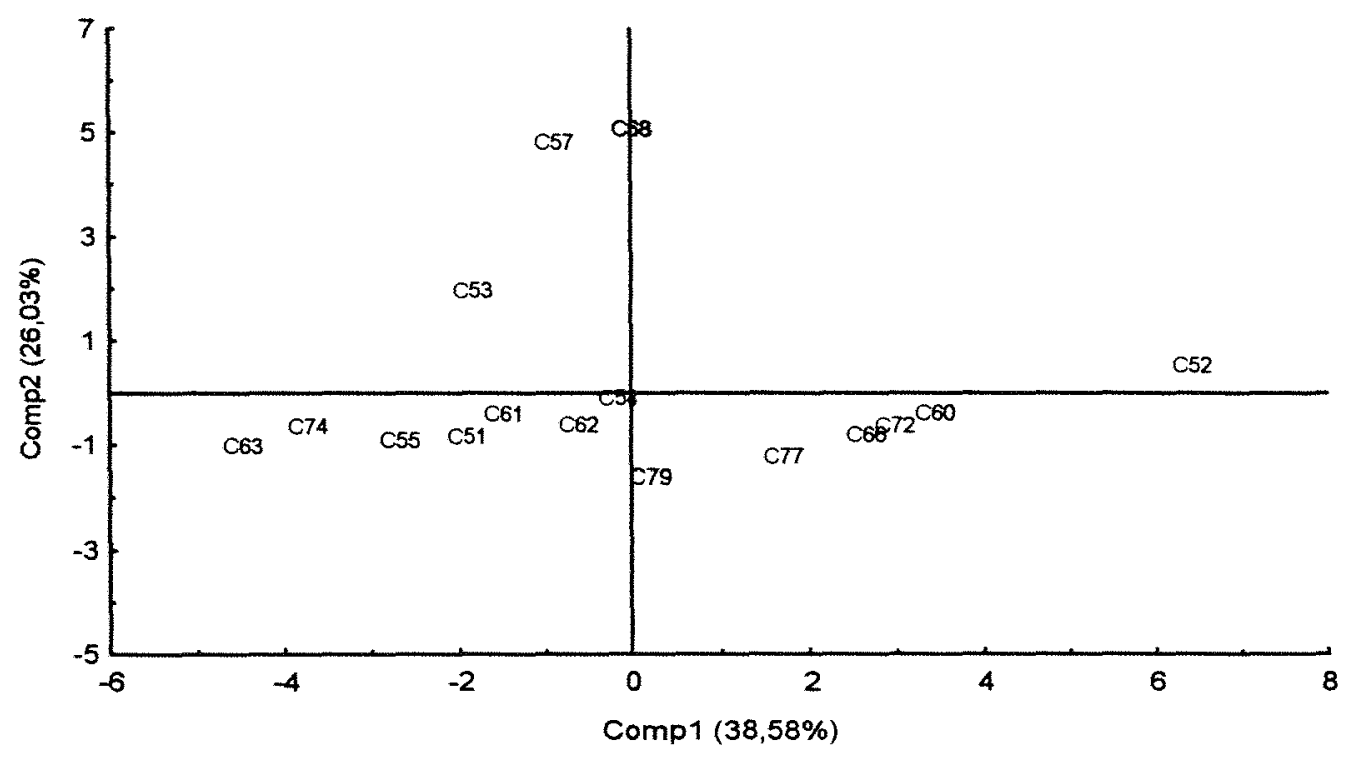

Figura 22. Escores provenientes da análise de componentes principais entre amostras de etnovariedades de mandioca de Ariri 1, roça 3 , considerando os componentes 1 e 2. 
Componentes principais 1 e 2 para as amostras da roça 3

Variäveis

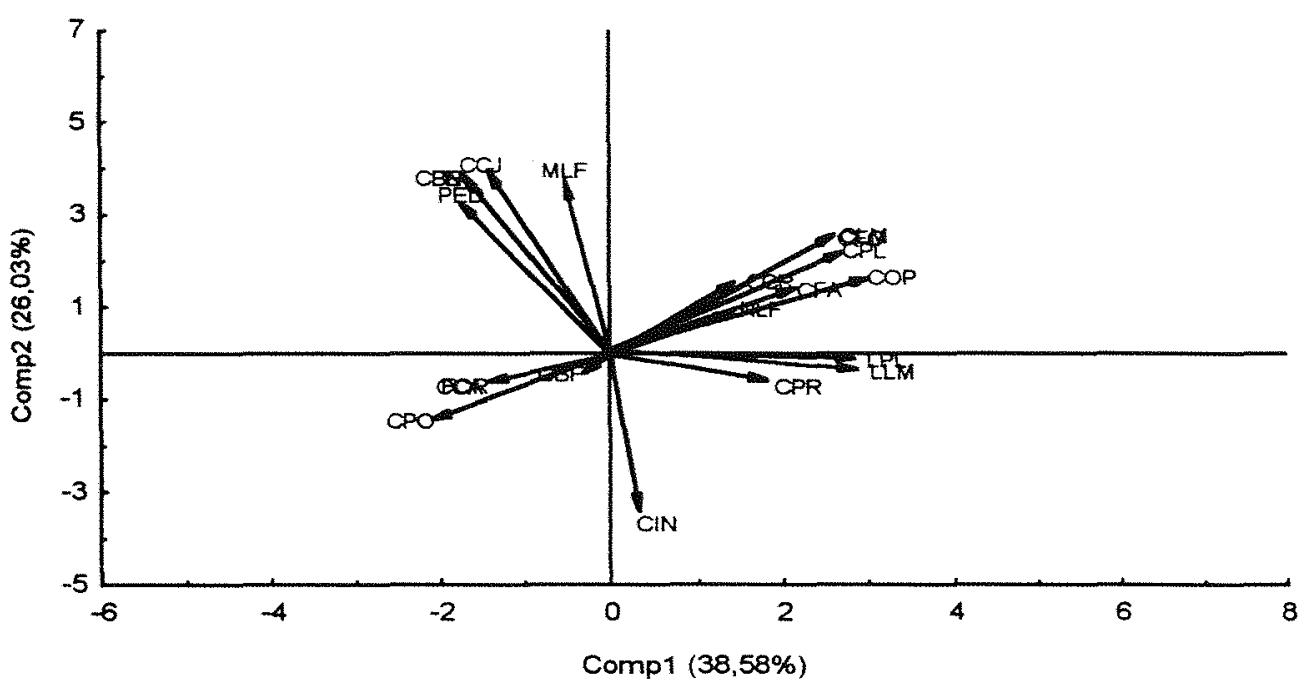

Figura 23. Contribuição das variáveis originais para os componentes principais 1 e 2 entre as amostras de etnovariedades de mandioca de Ariri 1, roça 3.

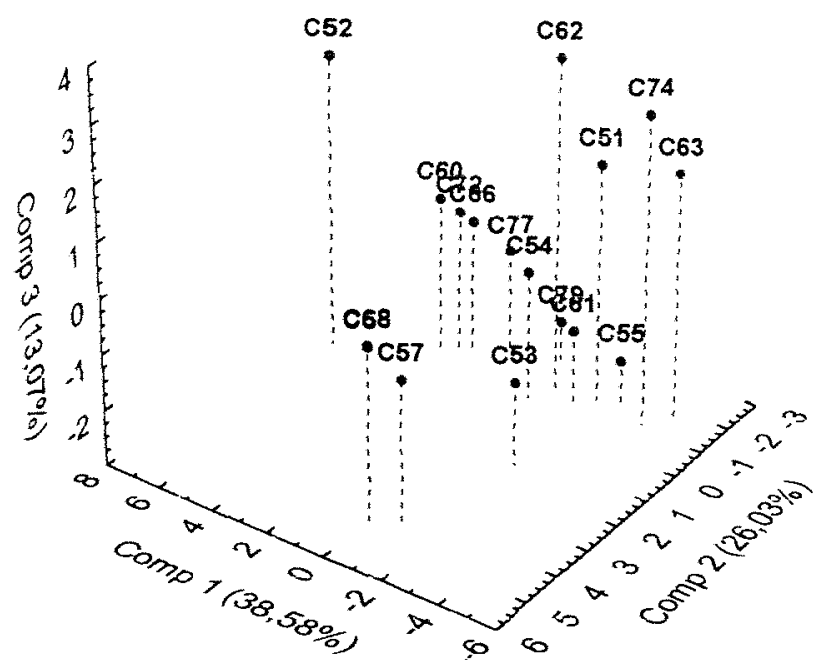

Figura 24. Escores provenientes da análise de componentes principais entre amostras de etnovariedades de mandioca de Ariri 1, roça 3, considerando os componentes 1,2 e 3 . 
Para a roça 1 de Ariri 1 (Figura 17), observa-se que o componente 1 diferencia dois grandes grupos, com a amostra A27 estabelecendo-se em posição intermediária. O componente 2 não forma grupos tão claros, o que é esperado, pois ele representa apenas $16,89 \%$ da variação total. As variáveis de maior importância para o componente 1 seriam a presença de cinta na raiz (CIN), presença de pedículo radicular (PED), cor da base da nervura da folha (CBN), cor do pecíolo das folhas adultas (CPF), e cor da folha adulta (CFA) (Figura 18). Aqui observa-se que caracteres de raiz, como cor da polpa (CPO) e cor da casca (CCR) e entrecasca (CPR) não são tão discriminantes como o esperado de acordo com os trabalhos Cury (1993) (através de análise multivariada de caracteres morfológicos), e Amorozo (1996) (utilizando caracteres que o agricultor apontava como discriminantes importantes para a classificação entre mandiocas bravas e mansas).

Na representação dos três primeiros componentes, com $69,20 \%$ da variação total, Figura 19, a separação dos grupos fica mais evidente. São observados 3 grupos melhor definidos, A, B e C, onde a amostra A27 poderia até ser considerada como representante de um novo grupo, entretanto parece ser uma amostra intermediária. Nesta roça o agricultor também identificava 3 variedades.

Para a roça 2 , os dois primeiros componentes representam $86,96 \%$ da variância e observa-se a existência de apenas 1 grande grupo propriamente dito (Figura 20), havendo a existência de duas amostras totalmente diferenciadas, B48 e B42, representativas de possiveis grupos. Observa-se que o componente 2 é mais eficiente na separação das duas amostras, com o grupo maior em posição central ao eixo. A 
presença de apenas um grande grupo confirma os resultados obtidos pela demografia estudada, onde constatou-se que $97.97 \%$ dos indivíduos identificados dentro dos quadradros amostrais são designados como "cascudinha", Tabela 4, ítem 4.1.4.

Em termos morfológicos pode-se concluir que as amostras coletadas representam apenas um grupo, ou apenas uma etnovariedade. A Figura 21 corrobora para esta interpretação, evidenciando que a maior parte dos caracteres estudados estão caracterizando estas amostras, confirmando as altas correlaçōes encontradas para estes caracteres.

Na roça 3, fica clara a necessidade de se utilizar 3 componentes que respondam por uma porção maior da variância total.

Se analisarmos apenas a dispersão obtida pelos dois primeiros componentes em conjunto, Figura 22, não são observados grupos definidos e suas relações. Entretanto pela Figura 24, fica mais evidente a presença de três grupos, separados principalmente pela inclusão do terceiro componente. No plano cartesiano bidimensional as amostras C62, C74, C51 e C63, ficam dispersas, não mostrando relação alguma, ao contrário do que demonstra a Figura 24.

Como os resultados das análises de agrupamento já sugeriram, a estruturação dos dados não é tão bem definida, o que restringe a elaboração de afirmações conclusivas sobre os grupos. Entretanto a análise de componentes principais foi útil, com este tipo de amostragem, para comparar de maneira generalizada o número de etnovariedades identificadas pelo agricultor com o que é avaliado morfologicamente, porém as informações quanto ao relacionamento das amostras entre si não ficam muito claras, pois não foi obtido o nome 
de cada amostra. Ficou claro que existe variação dentro dos possiveis grupos, porém a estrutura, ou a organização desta variação é diferente entre roças, evidenciada pela presença de caracteres diferentes que se destacam nos grupos. Isso evidencia também, que existe predominância de algumas variedades sobre outras, confirmando os resultados obtidos pela análise demográfica, que indicaram as diferenças de proporções de cada etnovariedade dentro das roças, e no caso da roça 2 e 3 a predominância de uma etnovariedade sobre as demais.

Esta amostragem sem a nomenclatura individualizada acaba sendo eficiente apenas para evidenciar a estrutura complexa da morfologia dentro das roças e as diferenças existentes, no nivel desta morfologia, entre grupos com que o agricultor se depara. Dentro desta estrutura são diferenciados os "representantes" ou mesmo os "tipos" que representam as etnovariedades, mas fica a pergunta em relação à precisão desta identificação e quanto ao relacionamento dos grupos reais existentes. A amostragem executada no ano de 1997 tenta responder a estas questōes.

A metodologia de amostragem feita em Ariri no ano de 1997 permite avaliar com mais segurança a precisão da nomenclatura utilizada, a relação entre grupos de nomes semelhantes ou que sugerem alguma proximidade, como "cascuda grande" e "cascudinha" , e uma possível, mas não confirmada, relação morfológica entre variedades ditas como "mansas" ou "doces".

Como ferramenta para responder a estas questōes, a análise de componentes principais foi bastante útil, quando complementada pelo 
método de agrupamento, para visualizaçāo de grupos e relaçōes de proximidade.

Para a roça 1, a representação bidimensional no plano cartesiano não é satisfatória, pois representa apenas $51,86 \%$ da variância total (Figura 25). Observa-se separação das amostras de "aipim guaçu" (AG9 e AG11) das demais, e a variedade "aipim manteiga" (AM30) em posiçāo intermediária, como é destacado principalmente pelo componente 2.

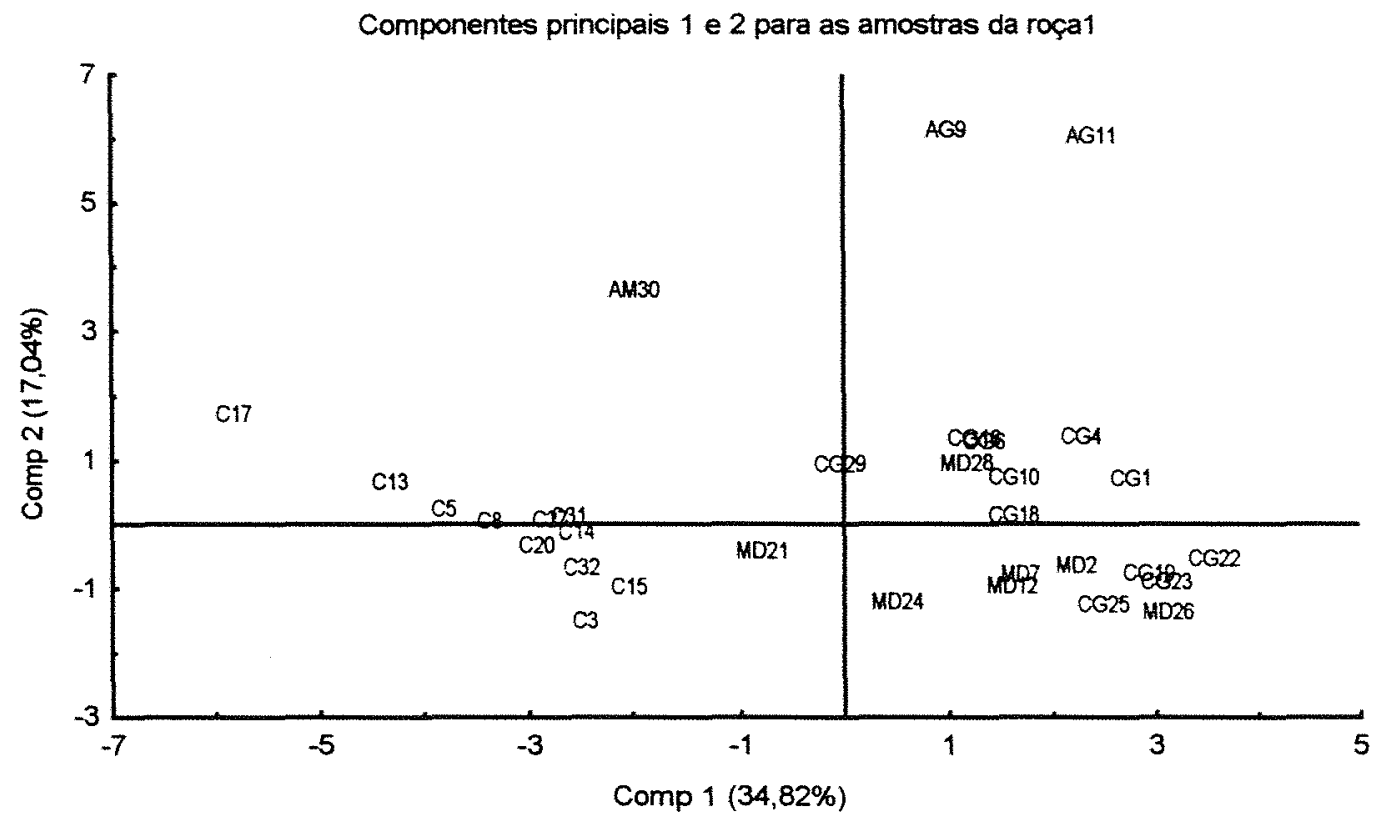

Figura 25. Escores provenientes da análise de componentes principais entre amostras de etnovariedades de mandioca de Ariri 2, roça 1. considerando componentes 1 e 2 . 
Componentes principais 1 e 2 para as amostras da roça 1

Variáveis

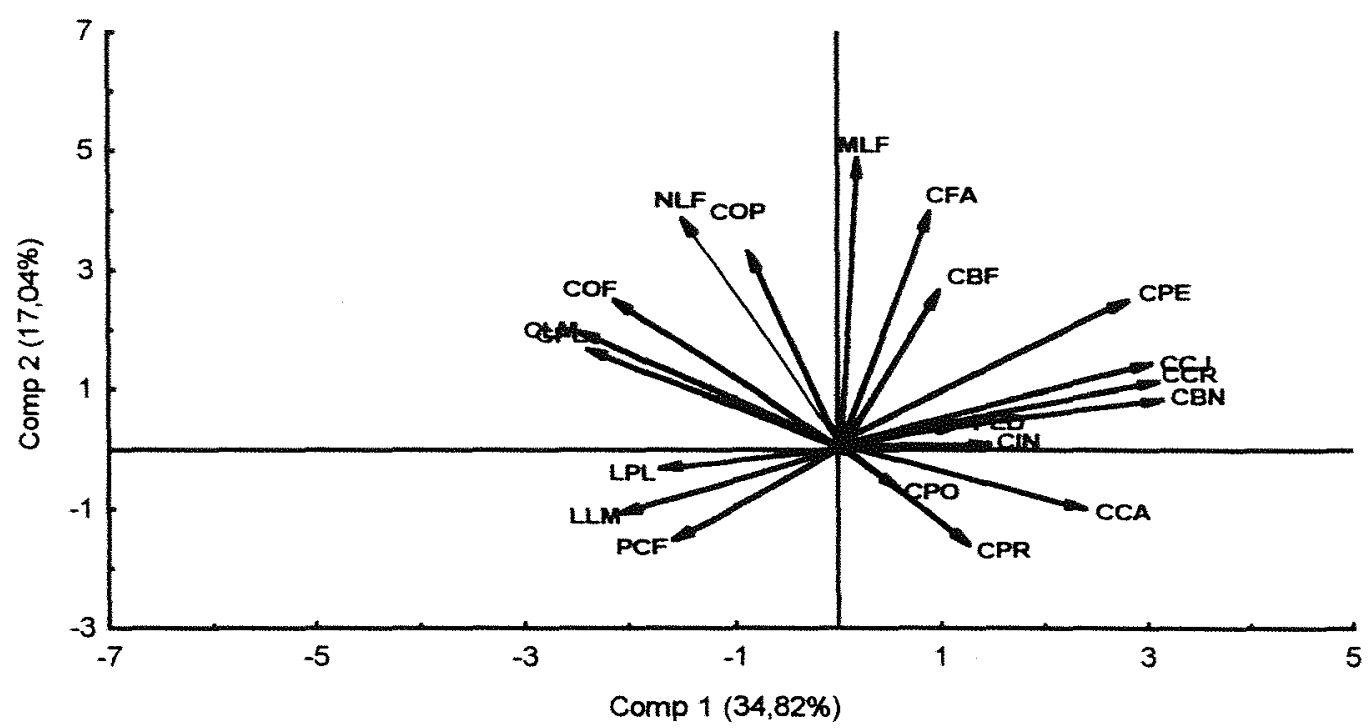

Figura 26. Contribuição das variáveis originais para os componentes principais 1 e 2 entre as amostras de etnovariedades de mandioca de Ariri 2, roça 1.

O componente 1, entretanto, com $34,82 \%$ da variaçāo é capaz de recuperar certa estrutura, no que diz respeito ao distanciamento das "cascudinhas" das "cascudas grandes", ficando as amostras de "mandipóia" em posição intermediária. O componente 2 concentra todas as "cascudinhas", "mandipóias" , e "cascudas grandes" num conjunto apenas. É interessante notar que justamente as amostras de "cascudinhas", que pelo nome sugerem ser ter dimensões "menores" que a "cascuda grande", são as que apresentam os valores mais extremos para caracteres como comprimento do lóbulo médio (CLM), comprimento do primeiro lóbulo à direita do lóbulo central (CPL), comprimento da folha (COF), e largura do primeiro lóbulo à direita do lóbulo central (LPL), Figura 26. De certa forma, isso confirma as observações do agricultor, que diz diferenciar estas etnovariedades das 
"cascudas grandes", que sugerem serem semelhantes às "cascudinhas" porém maiores, observando, além da morfologia, a maior altura alcançada pelo etnovariedade "cascuda grande" e o maior tamanho de suas raízes. Infelizmente, estes caracteres não foram avaliados a campo, fato que envolve discussōes mais gerais já há muito colocadas por Sneath \& Sokal (1973), Manly (1994) entre outros, sobre a escolha de caracteres que realmente descriminem a variação biológica existente.

Quando é analisada a dispersão com a inclusão do terceiro componente, fica evidente a separaçāo do grupo das "mandipóias" (MD) e uma sobreposição entre estas amostras e as "cascudas grande" (CG), Figura 27. Estes três componentes representam $64,03 \%$ da variância total. Apesar disso, fica claro pela representação dos três componentes, que a etnovariedade "mandipóia" é mais semelhante à etnovariedade "cascuda grande" do que esta em relação à "cascudinha", que pela sua nomenclatura poderia sugerir alguma proximidade. 


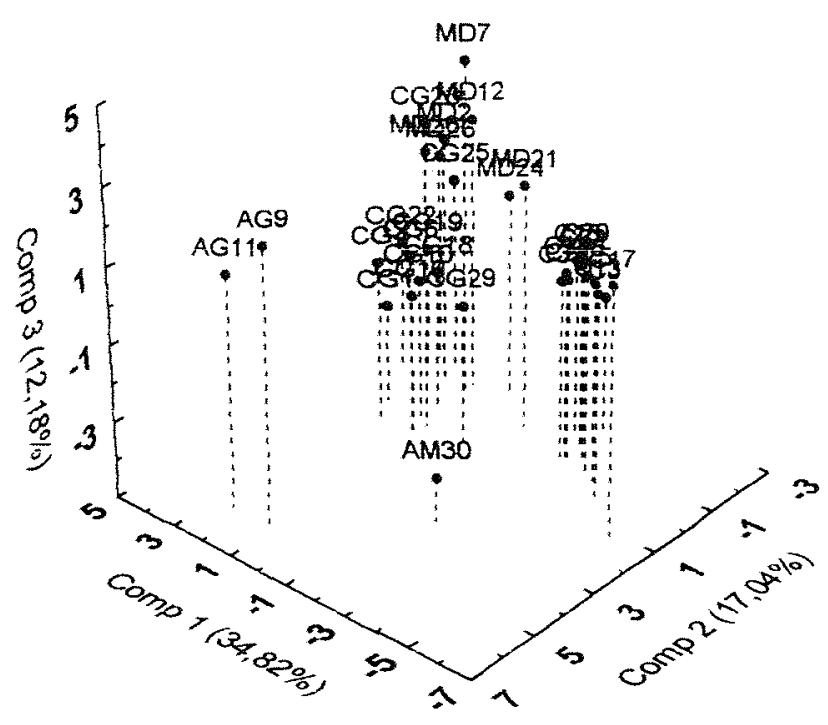

Figura 27. Escores provenientes da análise de componentes principais entre amostras de etnovariedades de mandioca de Ariri 2, roça 1 , considerando os componentes 1,2 e 3 .

Estrutura semelhante foi encontrada na roça 3, a qual é originária do mesmo conjunto que deu origem à roça 1, isto é, a roça 1 de Ariri 1.

A roça 3 apresenta o mesmo tipo de estrutura que a roça 1 de 1997, entretanto os componentes 1 e 2 acumulam proporção maior da variância, 65,70\%, Figura 28. Apesar disto não se pode falar em grupos distintos utilizando os componentes separadamente, mas sim em conjunto. Novamente o grupo das "cascudinhas" separa-se do resto e observa-se que as amostras de "mandipóia" ficam mais próximas às amostras de "cascuda grande" como ocorreu na roça 1 (Figuras 28 e 30). As amostras de "cascudinha" apresentam algumas características de folha como: largura do lóbulo médio (LLM) e largura do primeiro 
lóbulo à direita do lóbulo médio (LPL), e cor do broto foliar (CBF), mais expressivas que o grupo das cascudas grandes (Figura 29).

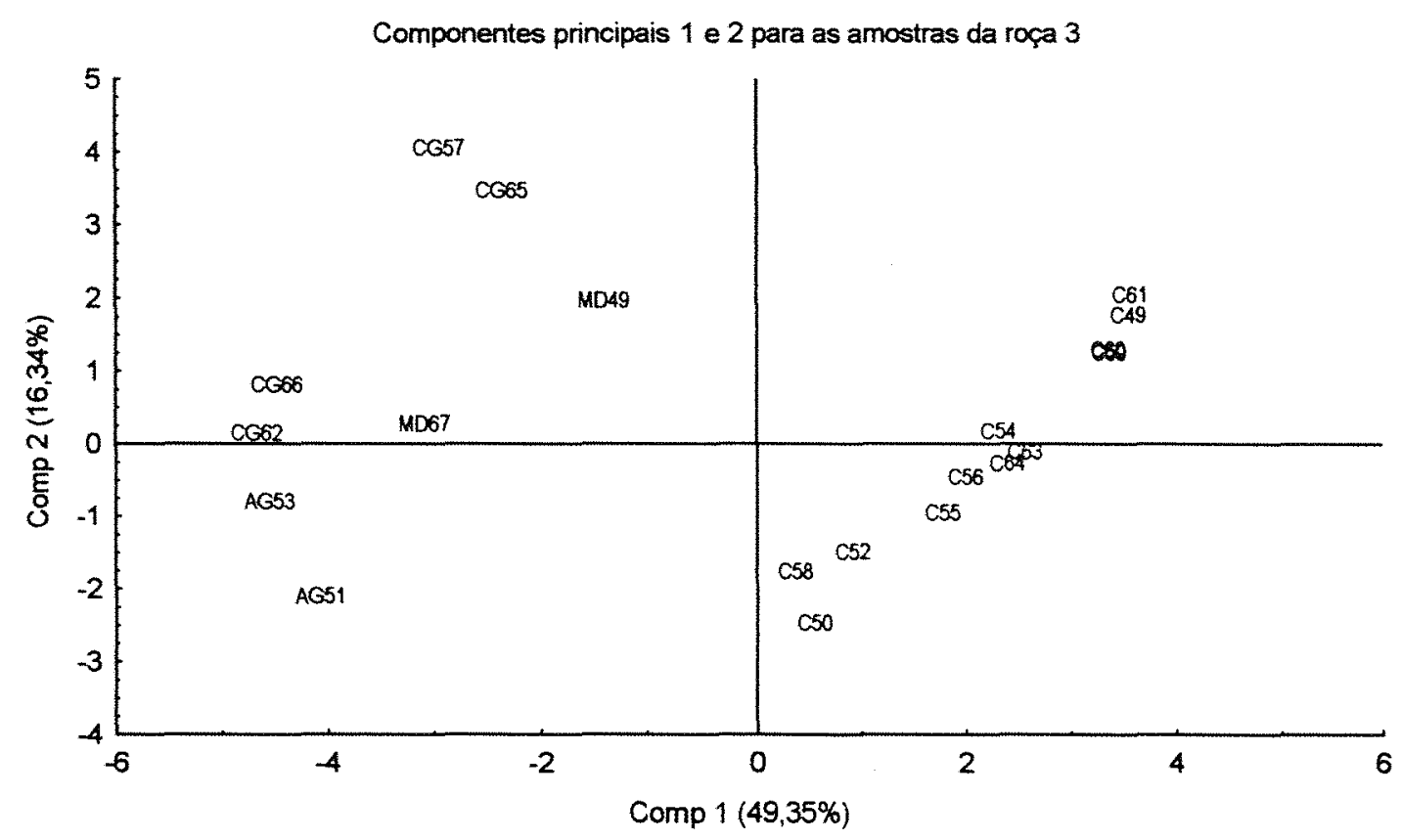

Figura 28. Escores provenientes da análise de componentes principais entre amostras de etnovariedades de mandioca de Ariri 2, roça 3, considerando os componentes 1 e 2. 
Componentes principais 1 e 2 para as amostras da roça 3

Variável

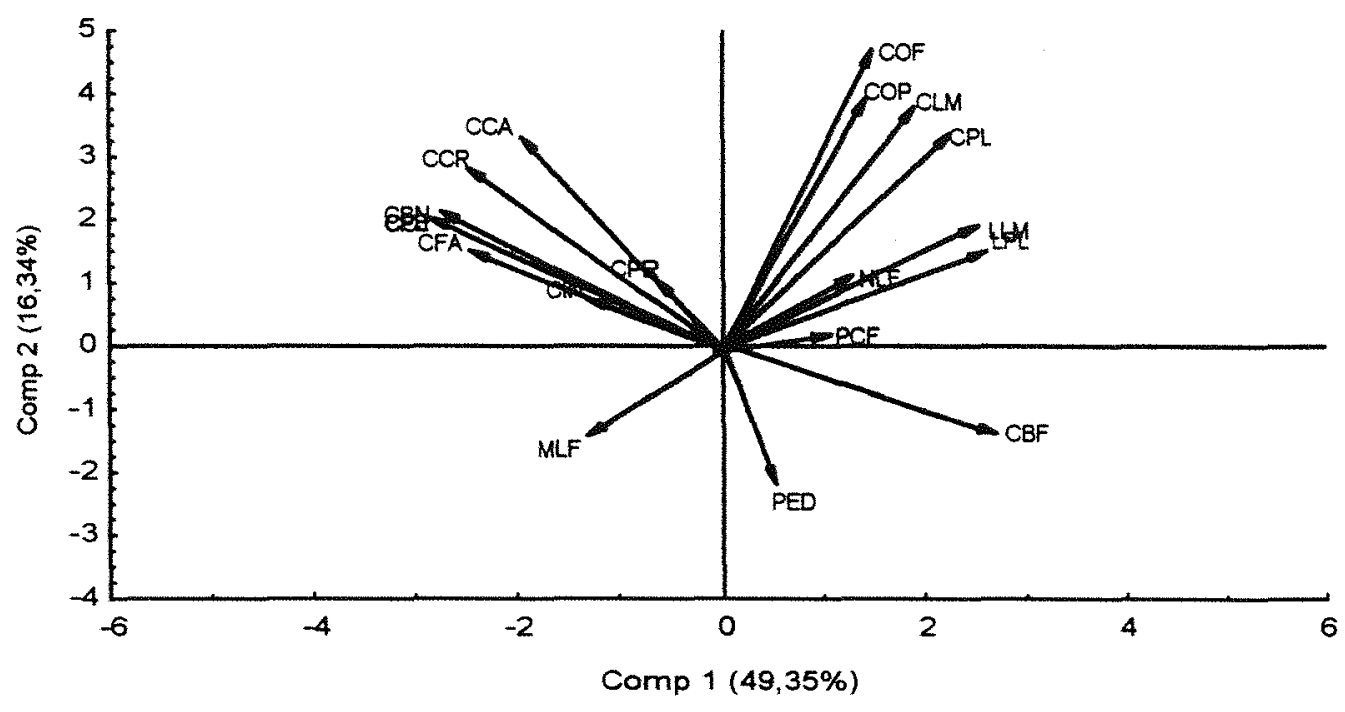

Figura 29. Contribuição das variáveis originais para os componentes principais 1 e 2 entre as amostras de etnovariedades de mandioca de Ariri 2, roça 3.

Componentes principais 1,2 e 3 para as amostras da roça 3

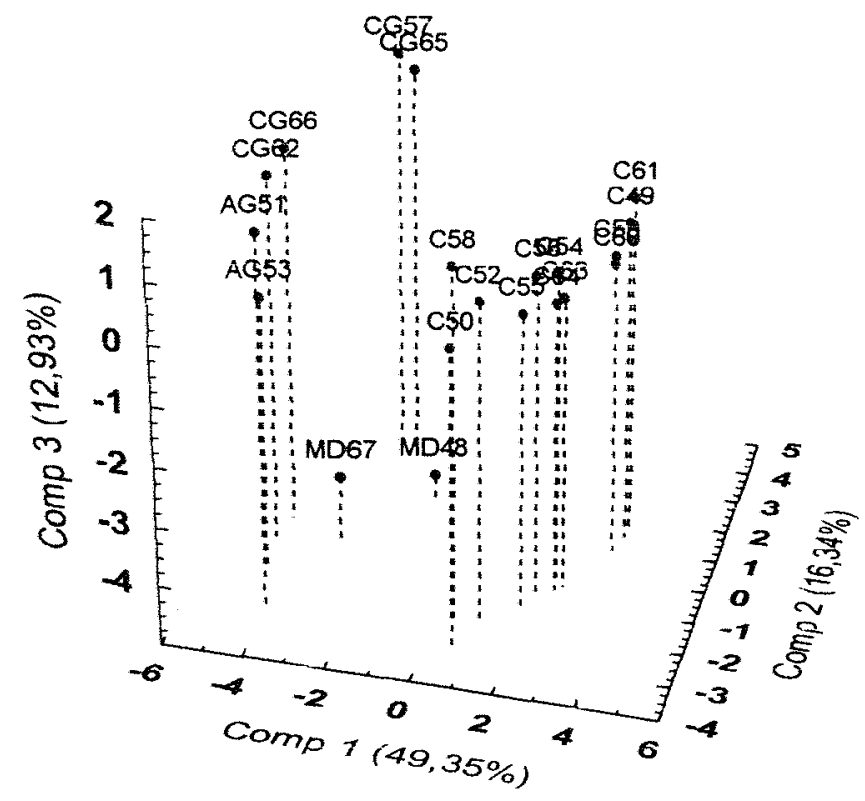

Figura 30. Escores provenientes da análise de componentes principais entre amostras de etnovariedades de mandioca de Ariri 2, roça 3, considerando os componentes 1, 2 e 3. 


\subsubsection{Descarte de variáveis}

No conjunto de amostras da roça 3 de Ariri2, procedeu-se o descarte de variáveis pelo método de Jolliffe (1972), amplamente utilizado em análises multivariadas. Esta roça foi escolhida para o descarte pois tem-se o nome de cada amostra e porque as análises de agrupamento e componentes principais indicaram melhor discriminação dos grupos. A roça 1, de acordo com estes critérios, também poderia ter sido estudada para o descarte, porém utilizou-se a roça 3 como modelo.

Quando são utilizadas muitas variáveis para o estudo de divergência é comum a presença de variáveis altamente correlacionadas e que podem descrever uma mesma amplitude de variação nas unidades operacionais (OUT'S) avaliadas. Sendo assim, são de utilidade métodos que possam eliminar estas variáveis de forma eficiente. O método descrito por Mardia et al. (1979) envolve a avaliação da importância dos descritores a partir dos coeficientes de ponderação (autovetores) das variáveis associadas aos últimos componentes que por construção, retêm proporção mínima da variação total. Quando se utiliza componentes principais, é recomendado que o número de variáveis rejeitadas seja igual ao número de componentes cujo autovalor seja inferior a 0.7 (Jolliffe, 1972). Sendo assim, a partir do menor autovalor até $\lambda<0,7$, escolhe-se a variável de maior coeficiente para o descarte, com valor absoluto, e que não tenha sido descartada previamente (Mardia et al., 1979).

Através deste método foi possivel o descarte de 7 variáveis: COF, CPL, LLM, CIN, LPL, PCF e COP. Com exceção da variável CIN, todas as outras são de natureza contínua, indicando que as variáveis discretas 
são melhores discriminantes da variabilidade existente entre etnovariedades.

A nova análise de componentes a partir do conjunto simplificado de variáveis mostra maior discriminação entre grupos de amostras (Figura 31). Entretanto os novos componentes obtidos não acumularam variância como o esperado. Apêndice 18, mas mesmo assim com dois componentes é possivel agora demostrar $72,43 \%$ da variância total e $84,13 \%$ se for incluído o terceiro componente (Figura 32).

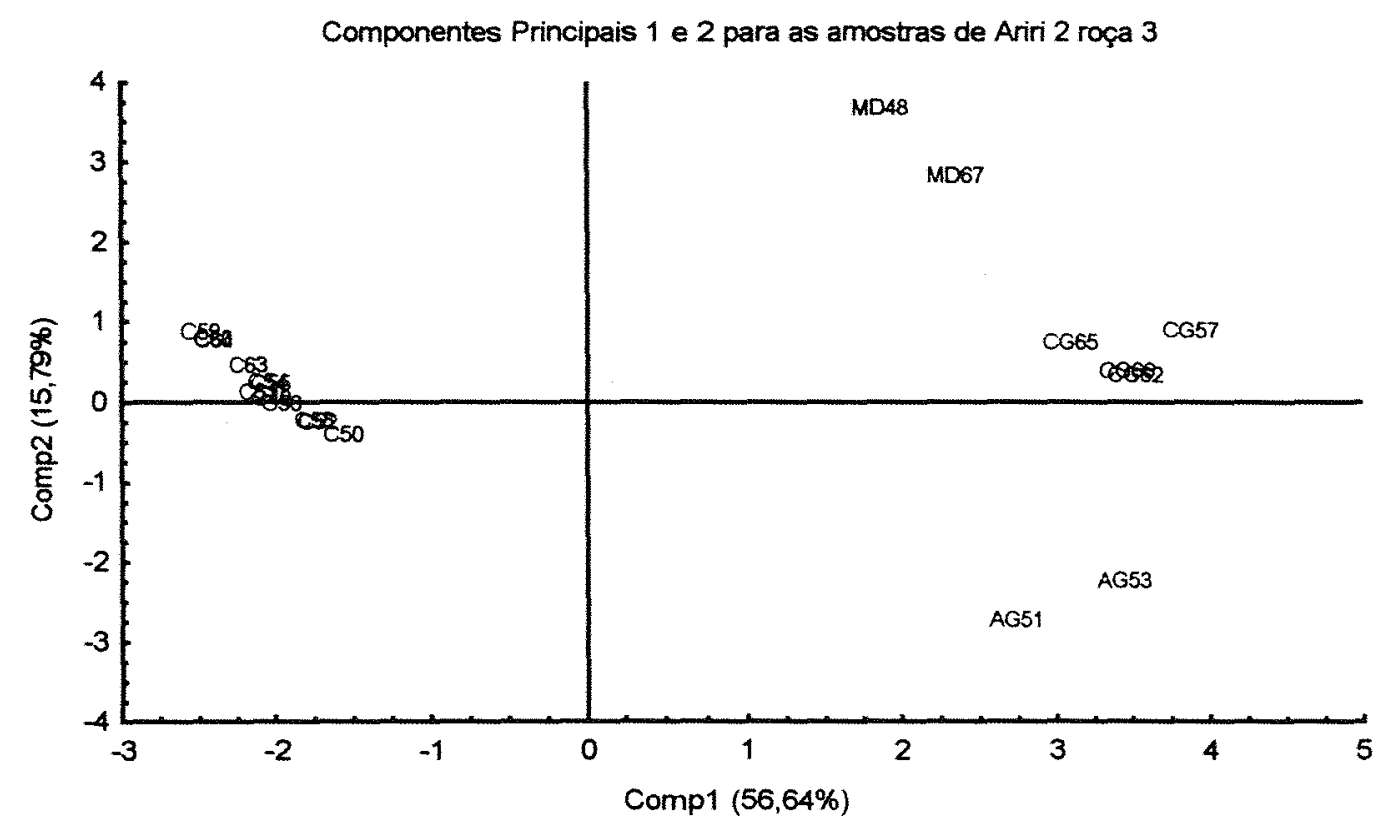

Figura 31. Escores provenientes da análise de componentes principais entre amostras de etnovariedades de mandioca de Ariri 2, roça 3, considerando os componentes 1 e 2 , com o conjunto simplificado de variáveis. 


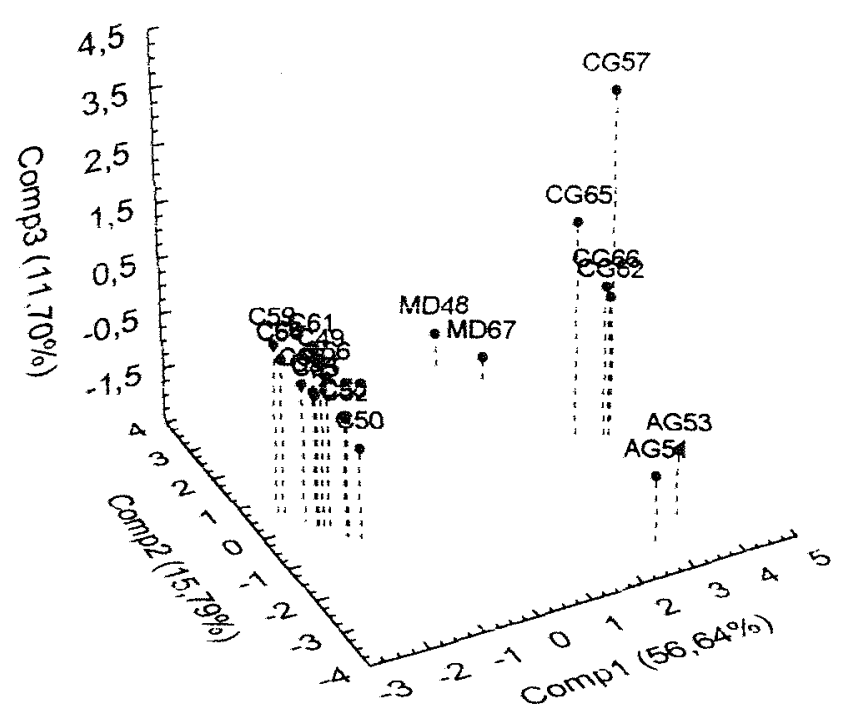

Figura 32. Escores provenientes da análise de componentes principais entre amostras de etnovariedades de mandioca de Ariri 2, roça 3, considerando os componentes 1,2 e 3 , com o conjunto simplificado de variáveis.

Para estas amostras, o descarte foi eficiente, pois possibilitou a simplificação do conjunto de descritores. Além disso, quando comparados os agrupamentos obtidos a partir do conjunto total de variáveis com o agrupamento formado após a eliminação, observa-se que não há alterações entre amostras que representam as etnovariedades mas sim há mudanças somente dentro da etnovariedade "cascudinha" (Figuras33 e 34). Observando também a matriz de correlaçōes, todas as variáveis descartadas apresentavam correlações elevadas com pelo menos uma variável mantida. 
Dendrograma para as amostras de Ariti2 roça 3 UPGMA

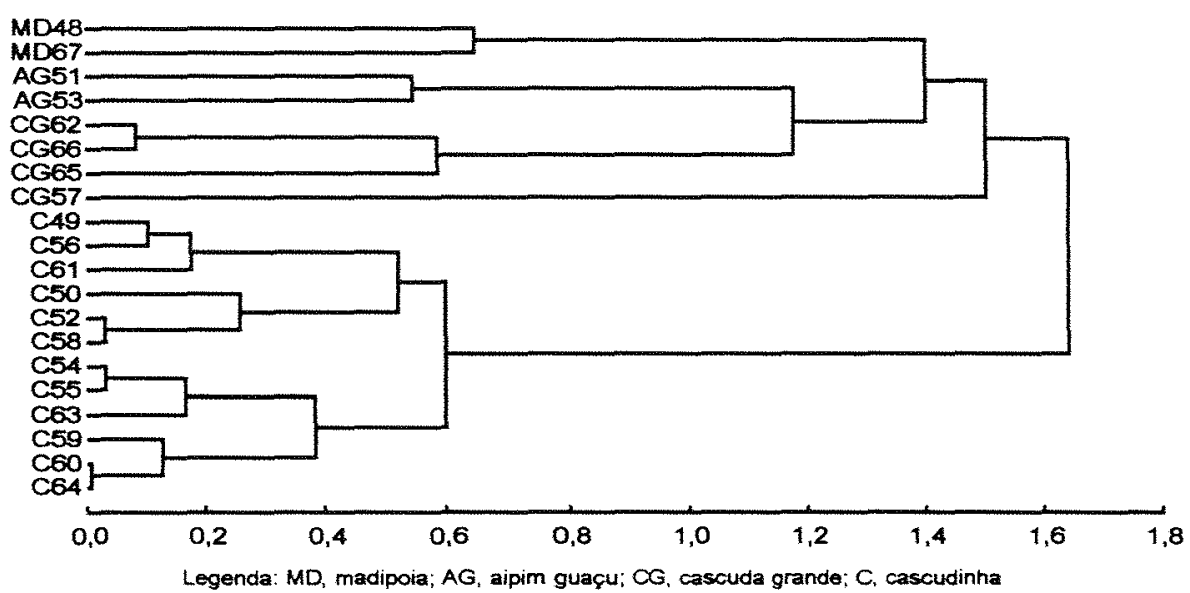

Figura 33. Agrupamento, através do método de UPGMA, das amostras de etnovariedades de mandioca de Ariri2, roça 3 , com o conjunto simplificado de variáveis e utilizando a matriz de distância euclidiana média.

Dendrograma para es amostras de Ariri 2 roca 3 Método de Ward

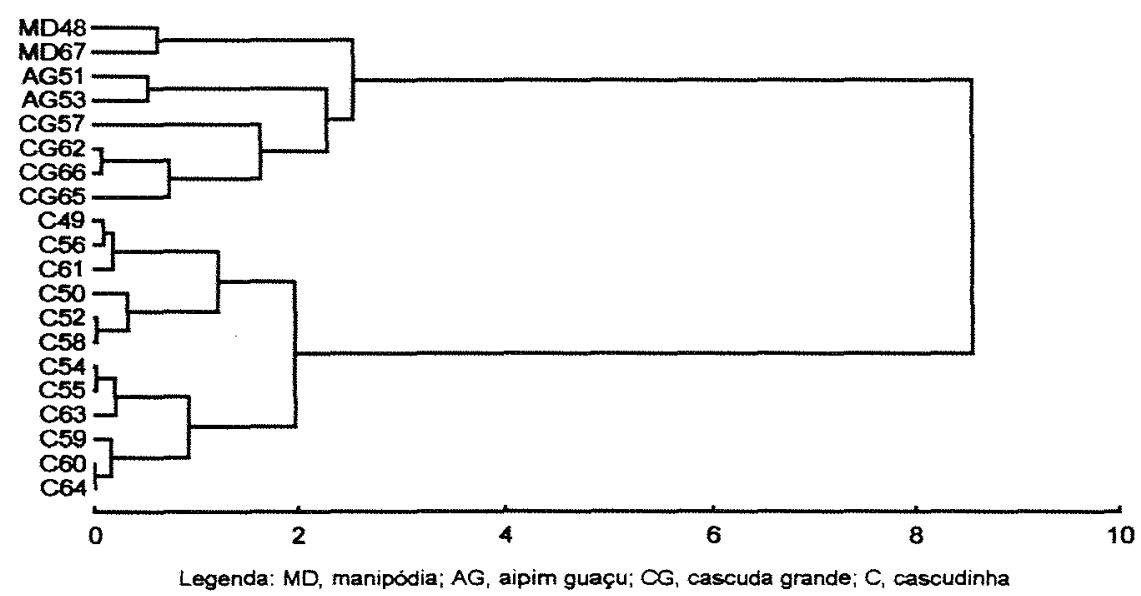

Figura 34. Agrupamento, através do método de Ward, das amostras de etnovariedades de mandioca de Ariri 2, roça 3, com o conjunto simplificado de variáveis e utilizando a matriz de distância euclidiana média. 
Outro ponto que realça a eficiência do descarte são os novos valores das correlações cofenéticas obtidos. Tanto utilizando o método UPGMA, como o método de Ward, foram obtidos valores mais altos para os novos agrupamentos. Com UPGMA, o valor elevou-se para 0,9646 e como método de Ward para 0,8705. Nota-se entretanto, que o indivíduo CG57 muda em termos hierárquicos, passando no método de Ward (Figura 34) a uma posiçāo intermediária entre o grupo das "cascudas grande" (CG) e dos "aipins guaçu" (AG).

De maneira geral, a eliminação das variáveis foi útil para reduzir o número de variáveis e na otimização do conjunto avaliado, com uma redução de $42,86 \%$ das variáveis, já que no processo inicial as variáveis SLF e CPO foram eliminadas por apresentarem d.p. $=0$. 


\subsection{Eletroforese de isoenzimas}

\subsubsection{Interpretação genética dos zimogramas}

O número de trabalhos na literatura que apresentam padrões genéticos utilizando eletroforese de isoenzimas em espécies do gênero Manihot não é grande, sendo eles muitas vezes contrastantes entre si (Borsoi Filho, 1995; Faraldo, 1995; Hussain ef al., 1987; Lefèvre \& Charrier, 1993 e Ramirez, 1987).

Apesar de existir a possibilidade de inferência sobre presença e diferenciação de locos e alelos para cada sistema enzimático, contrastando os dados obtidos com dados de literatura, optou-se pelo estudo das divergências intra e inter etnovariedades, baseando-se na presença e ausência de bandas. Foram analisados 340 indivíduos adultos, e não houve análise de progênies destes indivíduos dentro das populaçōes de referência.

Os padrões eletroforéticos obtidos podem ser observados na Figura 35, sendo que as Figuras $36,37,38$ e 39 apresentam as ilustrações de alguns dos melhores sistemas utilizados. Os resultados obtidos são semelhantes dos encontrados por Faraldo (1995) e por Lefèvre \& Charrier (1993).

Foram utilizados os seguintes sistemas: MDH, LAP, SKDH, PGI, GDH, CAT, AAT, MADH, $\propto-E S T, E M, P G M$, para a análise das seis roças de Ariri, sendo que GDH, MADH, EM, e PGM não foram analisados nas amostras de Praia Grande. Estes sistemas foram excluidos por terem sido pouco informativos, como observado nas análises anteriores, e para otimizar as análises dos 240 indivíduos representantes das roças desta região.

As bandas 1, 2 e 3 de PGI não foram consideradas nas análises 
das amostras de Ariril e Praia Grande, pois não apresentavam boa resolução na diferenciação de bandas.

A Figura 35 apresenta as bandas utilizadas nas análises, e os respectivos fenótipos obtidos nas 10 roças estudadas. Cada conjunto vertical de bandas, representa um fenótipo eletroforético diferente. O número de bandas obtido para cada sistema foi: sete para $M D H$, cinco para LAP, quatro para SKDH, 10 para PGI, três para GDH, uma para CAT, duas para AAT, duas para MADH, duas para EST, quatro para EM e três para PGM. Respectivamente, elas representam o seguinte número de fenótipos: três, quatro, três, sete, três, um, um, três, um, um e um. Quando surgiam dúvidas a respeito da posição das bandas para um deteminado individuo analisado, este era submetido à uma nova análise para se ter certeza a respeito da posição das bandas reveladas.

Na Figura 35, as bandas de SKDH estão representadas como dois grupos, A e B, pois, no decorrer das análises, a banda de número 4 foi inconstante quanto à sua resolução nos indivíduos de Praia Grande. Supōe-se que isto deva ter ocorrido em função da idade diferenciada das plantas, porque os indivíduos deste local foram analisados com aproximadamente 9 meses de idade, diferentemente das amostras de Ariril e 2, analisadas com 2 meses. Em testes prévios com plantas de mandioca, no Laboratório de Genética Ecológica do Depto. de Genética da ESALQ/USP, foram observadas algumas modificaçōes na definiçāo de bandas em alguns sistemas enzimáticos, quando analisados em plantas de idades diferentes. 


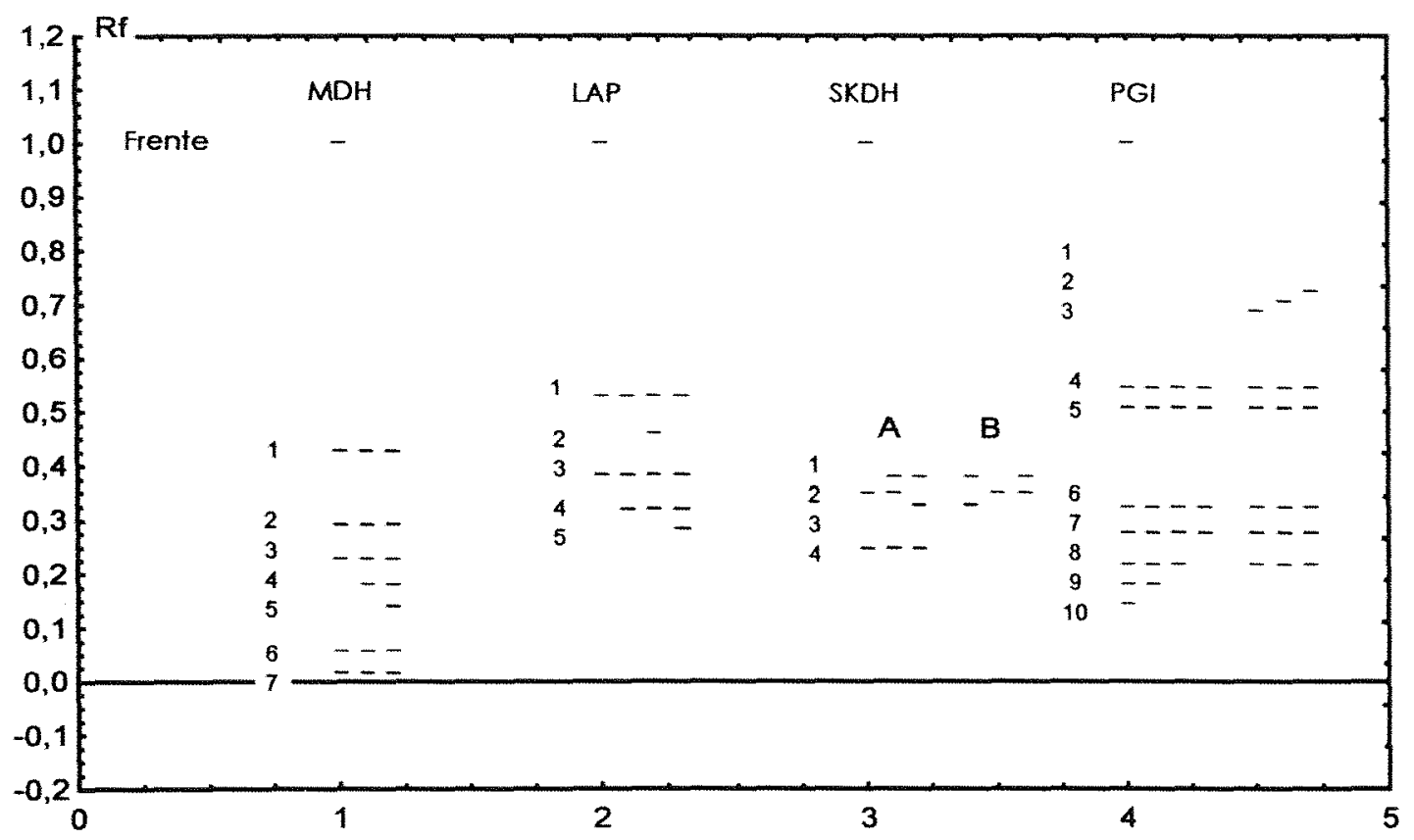

Número de sistemas

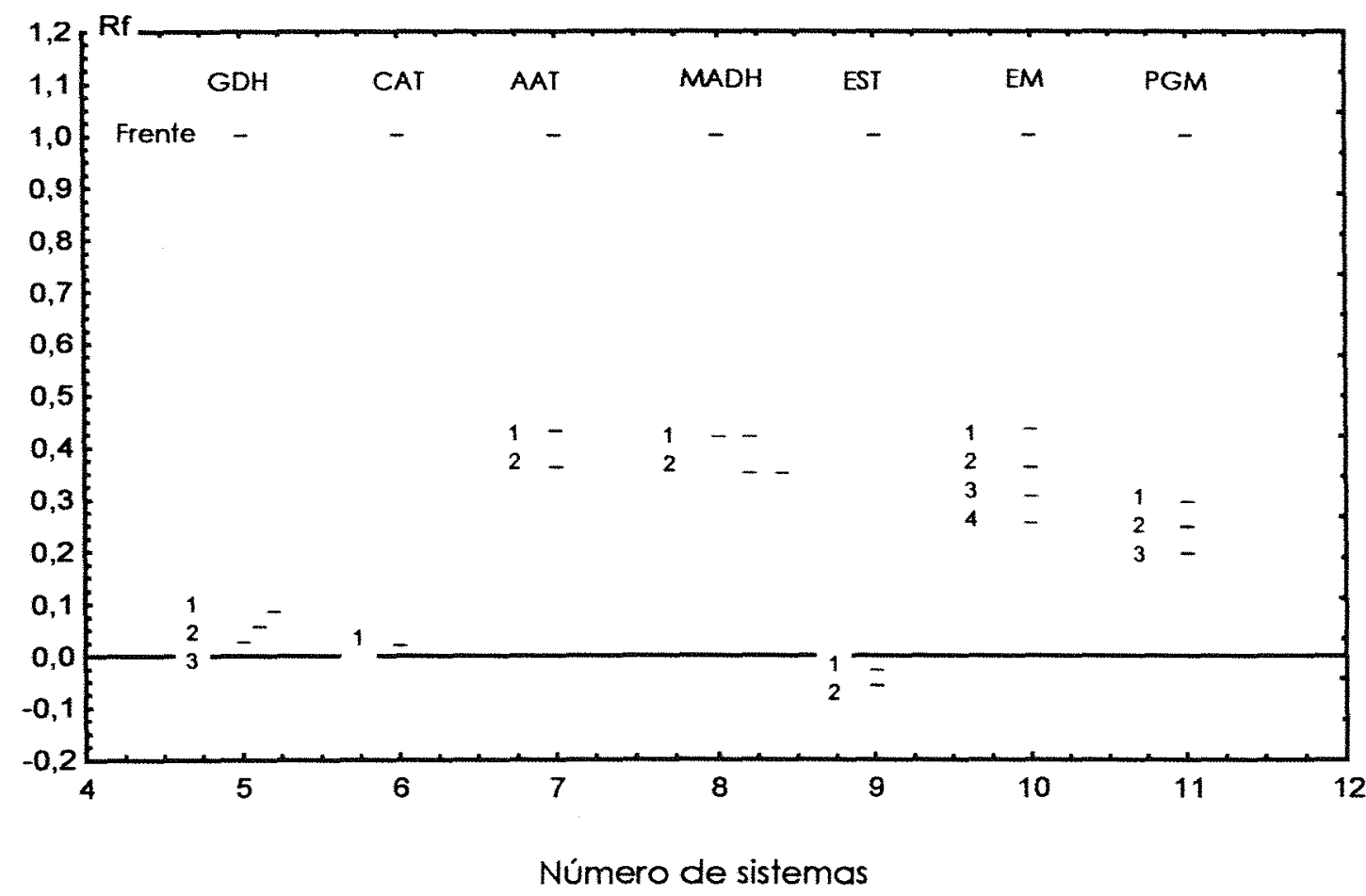

Figura 35. Zimograma dos padrões eletroforéticos apresentando todos os sistemas enzimáticos estudados. 


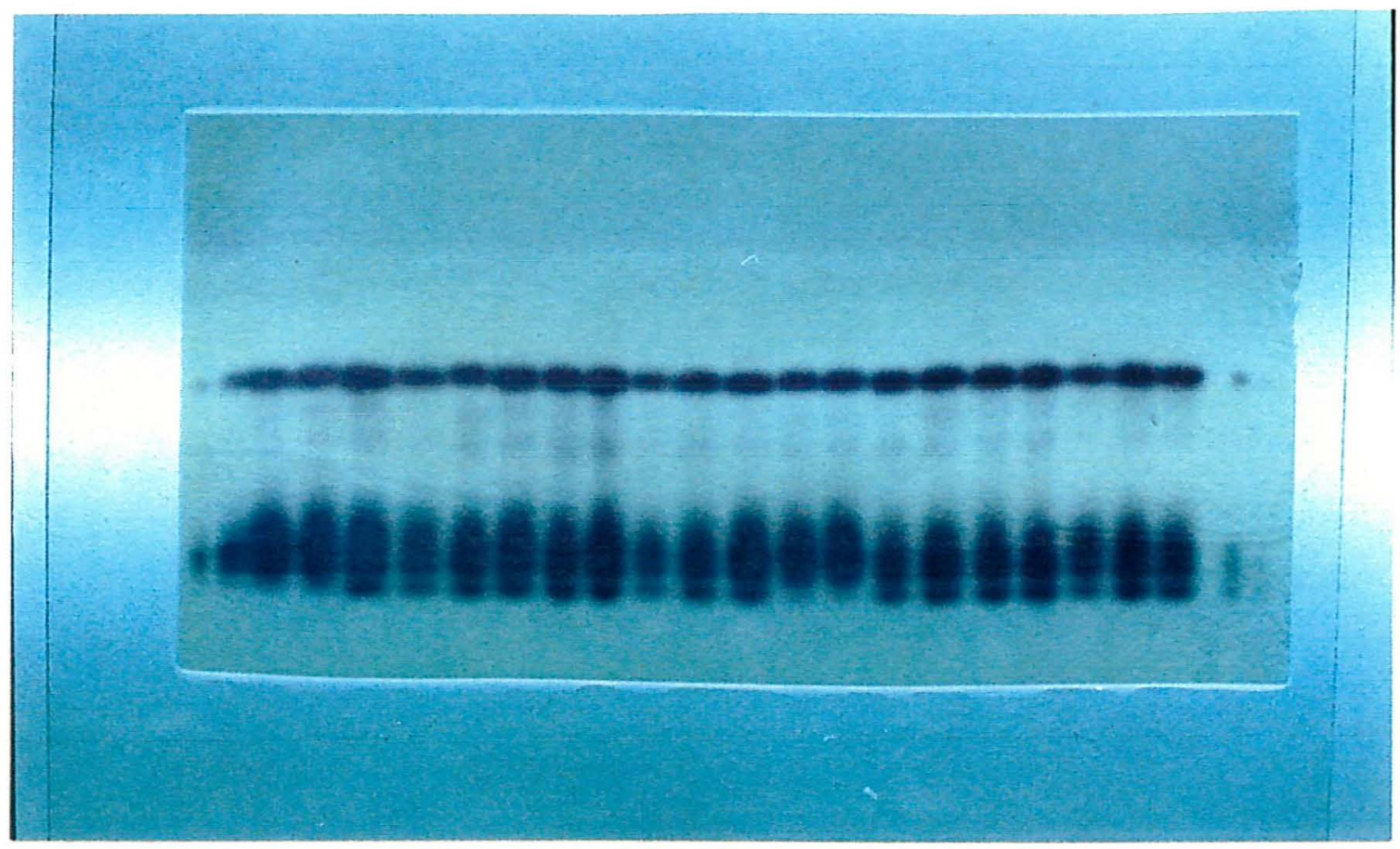

Figura 36. Foto do sistema enzimático PGI, mostrando 20 indivíduos amostrados em Ariri 1.

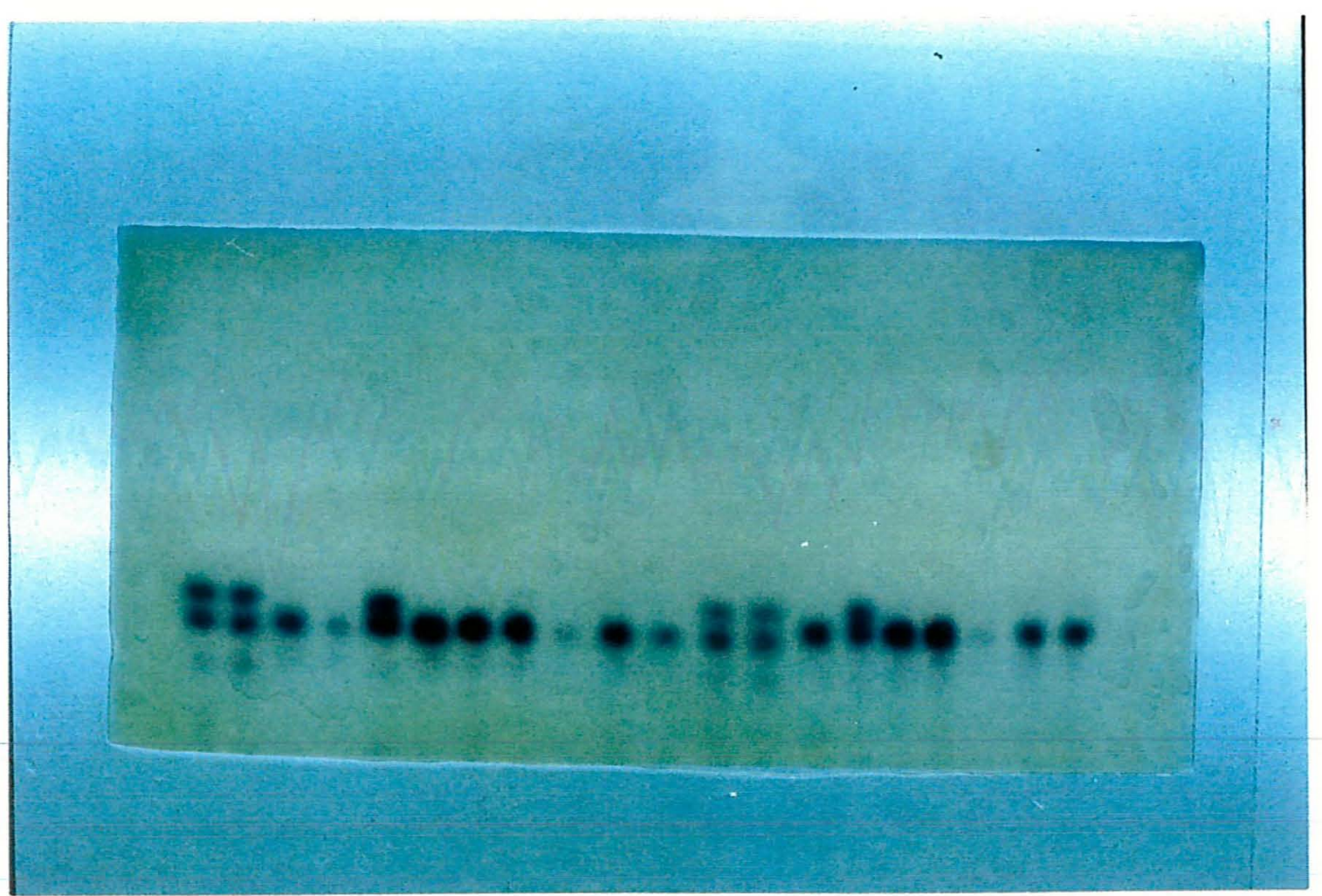

Figura 37. Foto do sistema enzimático SKDH, mostrando 20 indivíduos amostrados em Ariri 2. 


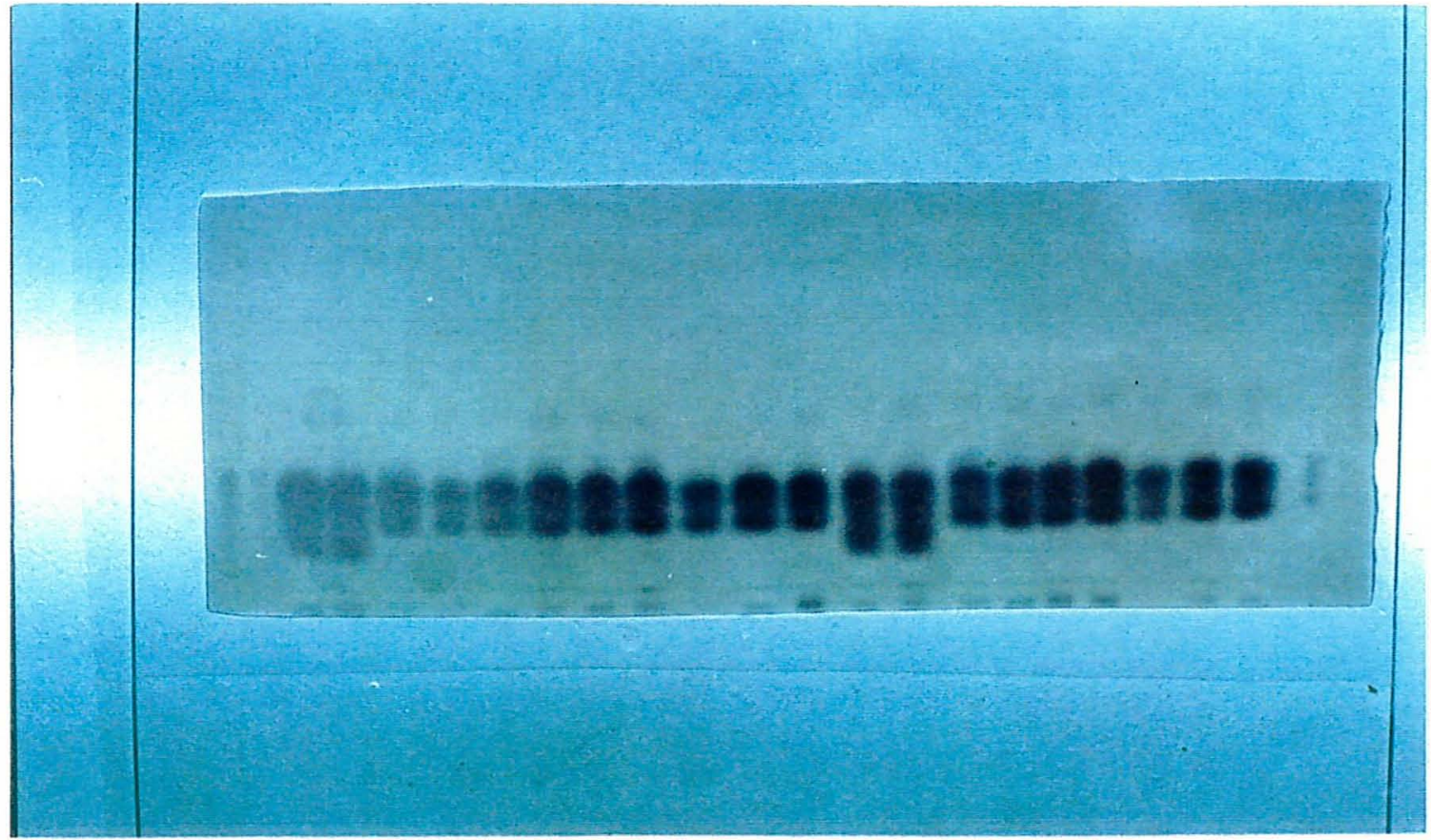

Figura 38. Foto do sistema enzimático MDH, mostrando 20 indivíduos amostrados em Ariri 2.

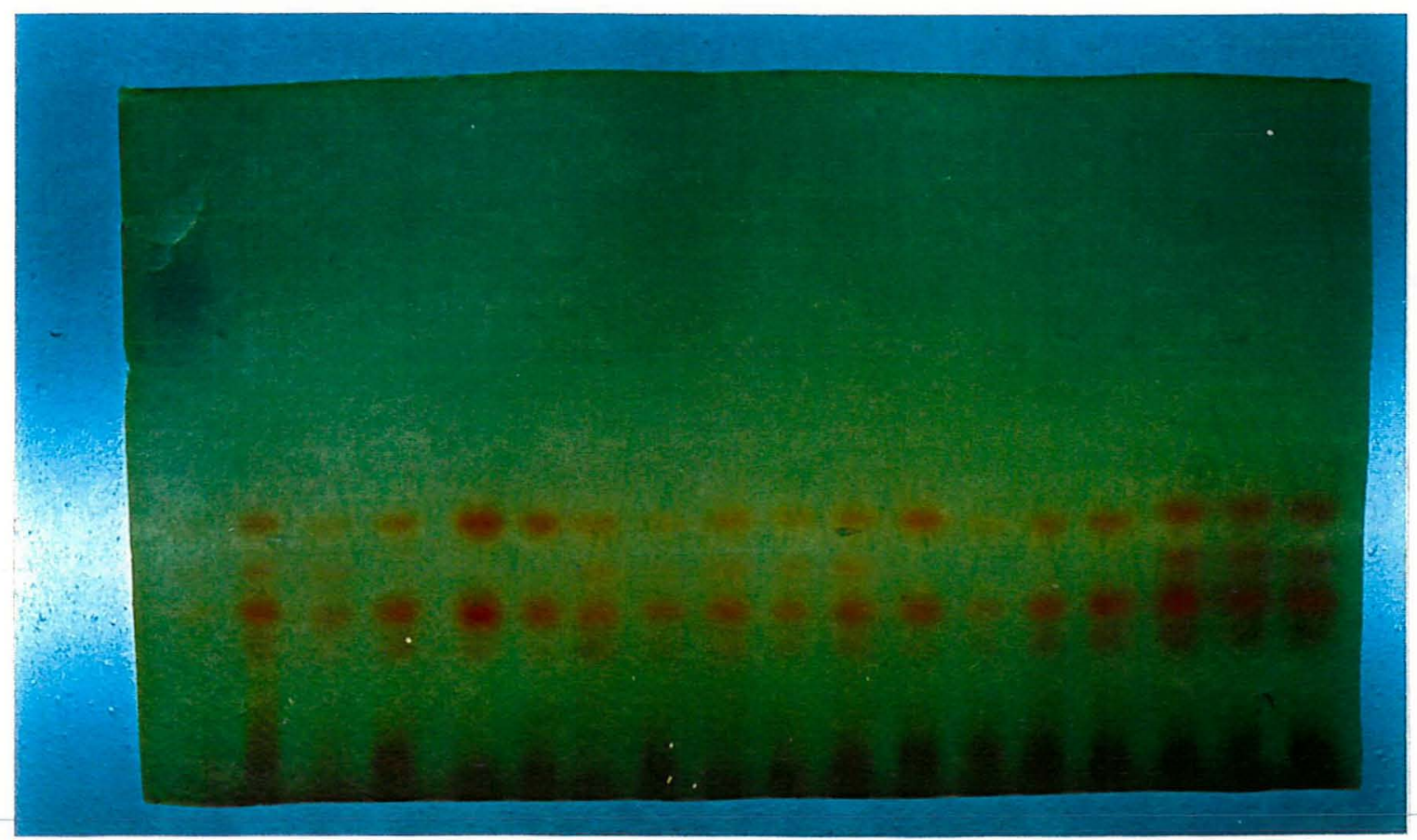

Figura 39. Foto do sistema enzimático LAP, mostrando 17 indivíduos amostrados em Ariri 1. 
As bandas obtidas numa amostra num determinado ano, não foram agrupadas com bandas de outro ano ou de outra localidade, pois o objetivo do trabalho está centrado na pesquisa da variaçāo dentro de roças e "dentro" de variedades.

Num contexto mais geral desta dissertação cabe ressaltar algumas observações sobre as frequências de bandas que se inserem no aspecto particular da divergência entre roças e entre regiōes. O uso de frequência de bandas, designada também como frequência fenotípica (Jain \& Singh, 1979 e Martins \& Jain, 1980), pode ser útil na comparação de populações quando não se tem a identificação de locos e alelos.

A análise visual da Tabela 10 mostra a existência de divergências entre as roças estudadas, através das diferenças nas frequências observadas. Cabe lembrar que o número de indivíduos por roça varia, e que também existem configuraçōes populacionais diferentes para cada roça. Mesmo assim é evidente a redução da variabilidade entre os anos de 1995 e de 1997, como mostra a fixação das bandas, MDH4 e MDH5 na roça 3, e eliminação de outras como PGI9 e PGI10 nas três roças de Ariri2, além de mudanças de frequências de bandas que podem estar refletindo aumento de frequência de alguns genótipos em detrimento de outros. 
Tabela 10. Frequências fenotípicas (\%do total de presença de uma banda) de todas as bandas dos sistemas enzimáticos.

\begin{tabular}{|c|c|c|c|c|c|c|c|c|c|c|c|}
\hline \multirow[b]{3}{*}{ Enzima } & \multirow[b]{3}{*}{$\mathrm{Rf}$} & \multicolumn{9}{|c|}{ Local } & \\
\hline & & \multicolumn{3}{|l|}{ Arivil } & \multicolumn{3}{|l|}{ Ariri2 } & \multicolumn{4}{|c|}{ Praia Grande } \\
\hline & & Roçal & Roça2 & Roça3 $\mathrm{F}$ & Roçal $\mathrm{f}$ & Roça2 & Roça3 F & Roçal $R$ & Roça2 & Roça3 & Roça4 \\
\hline $\mathrm{MDHI}$ & 0.43 & 1,0 & 1.0 & 1,0 & 1,0 & 1.0 & 1.0 & 1,0 & 1.0 & 1,0 & 1,0 \\
\hline $\mathrm{MDH} 2$ & 0,29 & 1,0 & 1,0 & 1.0 & 1.0 & 1,0 & 1,0 & 1.0 & 1.0 & 1.0 & 1.0 \\
\hline MDH3 & 0,23 & 1,0 & 1,0 & 1,0 & 1,0 & 1.0 & 1,0 & 1,0 & 1,0 & 1,0 & 1.0 \\
\hline $\mathrm{MDH} 4$ & 0,18 & 0.95 & 0,83 & 0,65 & 0,97 & 0,93 & 1,0 & 1,0 & 1,0 & 1,0 & 1.0 \\
\hline MDH5 & 0.14 & 0.95 & 0,83 & 0.65 & 0.97 & 0.93 & 1.0 & 0,08 & 0 & 0,02 & 0 \\
\hline MDH6 & 0,06 & 1.0 & 1.0 & 1,0 & 1.0 & 1.0 & 1.0 & 1.0 & 1,0 & 1,0 & 1,0 \\
\hline $\mathrm{MDH7}$ & 0.02 & 1,0 & 1.0 & 1.0 & 1,0 & 1,0 & 1.0 & 1,0 & 1,0 & 1.0 & 1.0 \\
\hline LAPI & 0,53 & 1,0 & 1,0 & 1,0 & 1.0 & 1.0 & 1,0 & 1,0 & 1,0 & 1.0 & 1.0 \\
\hline LAP2 & 0.46 & 0.50 & 0,67 & 0.41 & 0,34 & 0.47 & 0,60 & 0 & 0 & 0 & 0 \\
\hline LAP3 & 0,38 & 1,0 & 1.0 & 1,0 & 1,0 & 1,0 & 1,0 & 1,0 & 1,0 & 1.0 & 1,0 \\
\hline LAPA & 0.32 & 0.75 & 0,83 & 0,88 & 0,34 & 0.53 & 0,60 & 0.73 & 0,97 & 0.97 & 0.99 \\
\hline LAP5 & 0.29 & 0 & 0 & 0 & 0 & 0 & 0 & 0,73 & 0,97 & 0,97 & 0,99 \\
\hline SKDHI & 0,38 & 1,0 & 1.0 & 1.0 & 1.0 & 0.93 & 1.0 & 0,45 & 0,03 & 0,02 & 0,00 \\
\hline SKDH2 & 0,35 & 0.90 & 0,92 & 0,65 & 0.91 & 1.0 & 0,90 & 0,75 & 0.95 & 0,95 & 0.97 \\
\hline SKDH3 & 0.33 & 0.10 & 0,08 & 0,35 & 0,09 & 0 & 0.10 & 0.25 & 0.05 & 0.05 & 0.03 \\
\hline SKDH4 & 0,25 & 1,0 & 1.0 & 1.0 & 0,97 & 1,0 & 1,0 & 0 & 0 & 0 & 0 \\
\hline PGII & 0,73 & - & - & - & 0,31 & 0,20 & 0,25 & - & _- & - & - \\
\hline PGI2 & 0,71 & - & - & - & 0,34 & 0,60 & 0,30 & - & - & - & - \\
\hline PGI3 & 0,69 & & & & 0,38 & 0,20 & 0,65 & & & & \\
\hline PGI4 & 0,55 & 1.0 & 1,0 & 1.0 & 1.0 & 1,0 & 1.0 & $1, \overline{0}$ & 1.0 & 1.0 & 1.0 \\
\hline PGI5 & 0.51 & 1.0 & 1,0 & 1.0 & 1.0 & 1.0 & 1,0 & 1,0 & 1,0 & 1,0 & 1.0 \\
\hline PGI6 & 0,33 & 1.0 & 1,0 & 1.0 & 1.0 & 1,0 & 1,0 & 1,0 & 1,0 & 1.0 & 1.0 \\
\hline PGI7 & 0.28 & 1.0 & 1,0 & 1.0 & 1.0 & 1.0 & 1,0 & 0,94 & 0.97 & 1.0 & 1,0 \\
\hline PGI8 & 0,22 & 0,80 & 0,58 & 0.71 & 1.0 & 1,0 & 1,0 & 0,88 & 0,97 & 0,98 & 1,0 \\
\hline PGI9 & 0.18 & 0,10 & 0,08 & 0,35 & 0 & 0 & 0 & 0,03 & 0,05 & 0 & 0 \\
\hline PGIIO & 0.15 & 0 & 0 & 0,29 & 0 & 0 & 0 & 0.03 & 0,05 & 0 & 0 \\
\hline GDHI & 0,08 & 0,05 & 0 & 0.24 & 0 & 0 & 0 & - & - & - & - \\
\hline GDH2 & 0,06 & 0,25 & 0.08 & 0,35 & 0.22 & 0.20 & 0.25 & - & - & - & - \\
\hline GDH3 & 0,02 & 0.70 & 0.92 & 0.41 & 0.78 & 0,80 & 0,75 & & & & \\
\hline CAIl & 0.02 & 1.0 & 1.0 & 1,0 & 1.0 & 1.0 & 1,0 & 1.0 & $1 . \overline{0}$ & 1.0 & 1.0 \\
\hline AATI & 0.43 & 1,0 & 1,0 & 1,0 & 1,0 & 1.0 & 1,0 & 1.0 & 1,0 & 1,0 & 1.0 \\
\hline AAT2 & 0,36 & 1,0 & 1,0 & 1,0 & 1.0 & 1,0 & 1,0 & 1,0 & 1,0 & 1,0 & 1.0 \\
\hline MADHI & 0,35 & 1,0 & 1.0 & 0,88 & 1,0 & 1,0 & 1.0 & - & - & - & - \\
\hline $\mathrm{MADH} 2$ & 0,42 & 0 & 0 & 0,24 & 0 & 0 & 0 & & & 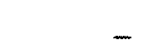 & \\
\hline ESTI & $-0,03$ & 1.0 & 1.0 & 1.0 & 1.0 & 1,0 & 1.0 & 1,0 & 1,0 & 1,0 & $1, \overline{0}$ \\
\hline EST2 & -0.06 & 1.0 & 1.0 & 1,0 & 1,0 & 1.0 & 1.0 & 1,0 & 1.0 & 1,0 & 1.0 \\
\hline EMI & 0,44 & 1,0 & 1.0 & 1,0 & 1.0 & 1,0 & 1.0 & - & - & - & - \\
\hline EM2 & 0,36 & 1,0 & 1,0 & 1,0 & 1,0 & 1.0 & 1,0 & - & - & - & - \\
\hline EM3 & 0,31 & 1,0 & 1,0 & 1,0 & 1,0 & 1,0 & 1.0 & - & - & - & - \\
\hline EM4 & 0,26 & 1,0 & 1,0 & 1,0 & 1.0 & 1,0 & 1.0 & 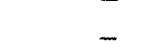 & - & - & \\
\hline PGMI & 0,30 & 1.0 & 1.0 & 1.0 & 1.0 & 1,0 & 1.0 & 1,0 & 1,0 & 1.0 & 1.0 \\
\hline PGM2 & 0,25 & 1,0 & 1,0 & 1.0 & 1,0 & 1.0 & 1.0 & 1,0 & 1.0 & 1.0 & 1.0 \\
\hline PGM3 & 0.20 & 1.0 & 1,0 & 1.0 & 1,0 & 1,0 & 1.0 & 1.0 & 1,0 & 1.0 & 1,0 \\
\hline & $N$ & 20 & 12 & 17 & 32 & 15 & 20 & 34 & 37 & 64 & 69 \\
\hline
\end{tabular}


Apesar dos individuos entre locais terem sido analisados com idades diferentes, pode-se observar que existem bandas ausentes $e$ presentes nas distintas regiōes, como LAP2 que está presente na Regiāo de Ariri (Cananéia) e ausente nas roças da região de Praia Grande (Iporanga). Isto ocorre inversamente para o mesmo sistema enzimático com a banda LAP5. Isso sugere a presença de alelos diferentes nas populações analisadas sob pressões seletivas diferentes e sob ação de deriva genética. Cabe lembrar que 0 agricultor seleciona etnovariedades entre anos, mudando a configuração de suas roças, como também utiliza parte de uma roça antiga para fundar uma nova roça.

4.3.2 Relaçōes fenéticas entre etnovariedades e indivíduos baseadas em dados de eletroforese de isoenzimas

As similaridades entre indivíduos, comparados dois a dois, estão representadas nos Apêndices 19 a 28. Para a elaboração do índice de semelhança simples (Simple Machting), foi considerada a presença de 40 bandas em Ariri 1, 43 em Ariri 2 e 28 bandas em Praia Grande.

A partir dos índices, foi possivel a construção de dendrogramas que refletem a máxima semelhança entre individuos quando o valor é 1,0. e a máxima diferença quando o valor é 0,0 . Serão apresentados os dendrogramas por grupos de roças analisadas, onde estão indicadas as distâncias, que são as diferenças entre o valor de semelhança e o valor 1, isto é, (1-coeficiente de semelhança).

O fator determinante do número de bandas é o número de alelos diferentes por loco e a maneira como seus produtos se combinam entre 
si na formação das enzimas (Kephart, 1990). Logo, se existe polimorfismo, ele é reflexo das combinações alélicas que possam ocorrer dentro de uma população, e será refletido em constituiçōes genotipicas diferenciadas. Padrões de bandas diferentes, ou fenótipos enzimáticos diferentes, refletem as divergências nas constituiçōes genotípicas.

\subsubsection{Análise de Agrupamento}

Serão aqui apresentados todos os dendrogramas obtidos por roça nos diferentes anos e nas diferentes regiōes. As Figuras de 40 a 42 , de 43 a 46 , e de 47 a 50 representam os agrupamentos dos indivíduos amostrados respectivamente em Ariril, Ariri2, e Praia Grande.

Todos os agrupamentos foram obtidos pelo método hierárquico aglomerativo UPGMA. Destacamos aqui as relaçōes entre grupos e a presença de genótipos diferentes "dentro" das etnovariedades.

Os valores de correlação cofenética são todos altos, indicando que existe classificação e que os agrupamentos são satisfatórios, Tabela 11. Entretanto, pela análise de diferentes métodos aglomerativos incluindo o de ligação completa, houve algumas mudanças de posição de um indivíduo na roça 1 e na roça 3 de Ariri 2 (Figuras 44 e 47). Portanto, as discussōes sobre relaçōes entre grupos são relacionadas aos mais "compactos", sendo que esta exceção não atrapalha a visão geral dos agrupamentos. 
Tabela 11. Coeficiente de correlação cofenético para todas as roças estudadas.

\begin{tabular}{ll}
\hline Roça* & Correlação Cofenética (UPGMA) \\
\hline Arl R1 & 0.9435 \\
Ar1 R2 & 0.9778 \\
Ar1 R3 & 0.9266 \\
Ar2 R1 & 0.9014 \\
Ar2 R2 & 0.9100 \\
Ar2 R3 & 0.9020 \\
PG R1 & 0.8397 \\
PG R2 & 0.9609 \\
PG R3 & 0.9972 \\
PG R4 & 0.9948 \\
\hline *Legenda: Ar, Ariri; Pg. Praia Grande, R. roça
\end{tabular}

As diferenças encontradas nos coeficientes de semelhança, calculados entre genótipos, variam entre roças, refletindo as composiçōes genotípicas diferenciadas, Tabela 12.

O cálculo do Coeficiente de similaridade genética entre todos os indivíduos, revelou valores extremos de 1,0 entre clones, até 0,692 entre genótipos. O valor de máxima semelhança encontrado entre genótipos diferentes chegou a $97.6 \%$, revelando a grande proximidade destes genótipos em relação as bandas estudadas. 
Tabela 12. Valores máximos, mínimos e médios dos índices de similaridade obtidos nas roças estudadas.

\begin{tabular}{llll}
\hline Roça & Valor máximo* & Valor mínimo & Valor médio \\
\hline Ar1 R1 & 0.974 & 0.795 & 0.924 \\
Ar1 R2 & 0.974 & 0.769 & 0.929 \\
Ar1 R3 & 0.974 & 0.692 & 0,845 \\
Ar2 R1 & 0.976 & 0.738 & 0.915 \\
Ar2 R2 & 0.952 & 0.810 & 0.929 \\
Ar2 R3 & 0.952 & 0.810 & 0.917 \\
PG R1 & 0.966 & 0.690 & 0.730 \\
PG R2 & 0.966 & 0.724 & 0.869 \\
PG R3 & 0.931 & 0.758 & 0.856 \\
PG R4 & 0.931 & 0.862 & 0.908 \\
\hline
\end{tabular}

*Os valores máximos encontrados excluem os clones que possuem índice igual a 1 .

A principal informação resgatada pelas dendrogramas é a presença de genótipos diferentes e em número maior que o identificado pelo agricultor e indicado pelas análises morfológicas.

Em Ariri 1 há subestimaçāo da variabilidade presente dentro da roça, e o que o agricultor menciona como 3 variedades diferentes na roça 1, na verdade sāo 11 genótipos, compreendendo diferentes configurações quanto ao número de clones para cada genótipo (Figura 40). Na roça 2 há 6 genótipos diferentes quando se identificou apenas dois (Figura 41 ) e na roça três são 10, sendo identificados entretanto três, Figura 42.

As discrepâncias entre o número de genótipos diferenciados nesta coleta, na roça 1, podem ser efitivamente menores devido à identificação feita pelo informante. Em uma conversa prévia em 1995 com informante mais velho, na roçal deste ano havia as seguinte etnovariedades: "aipim roxo", "aipim amarelo" ou "manteiga", "aipim guaçu", "aipim vassourinha", "mandipóia", "cascuda", e "imperial", entretanto seu irmão, que acompanhou a coleta das amostras, 
conseguiu identificar 3 delas: "cascuda", "aipim roxo" e "aipim manteiga". Isso pode sugerir que algumas amostras de efnovariedades tenham sido coletadas mas que não tenham sido identificadas com segurança. Apesar disto, mesmo o informante mais velho tendo citado 7 etnovariedades, nesta roça tem-se 11 genótipos diferentes, que mostra que a subestimação é aparente.

A princípio, alguns fatores podem ter contribuido para a diferença entre o que foi informado previamente e o que foi identificado, na roça 1. No mês de junho, as plantas começam a perder as folhas em decorrência do início do inverno, assim muitos indivíduos apresentavam poucas folhas para uma identificação mais segura; a grande maioria das variedades estava presente na roça em baixa frequência, havendo predominância de apenas uma, como pode ser visto no levantamento demográfico (Tabelas 3 e 4, item 4.1.4). Segundo o informante, a grande maioria das variedades estava na roça para não "perder a muda", funcionando como autênticos bancos de germoplasma. 
Dendrograma para 20 individuos (Ariri 1 roça1)

UPGMA

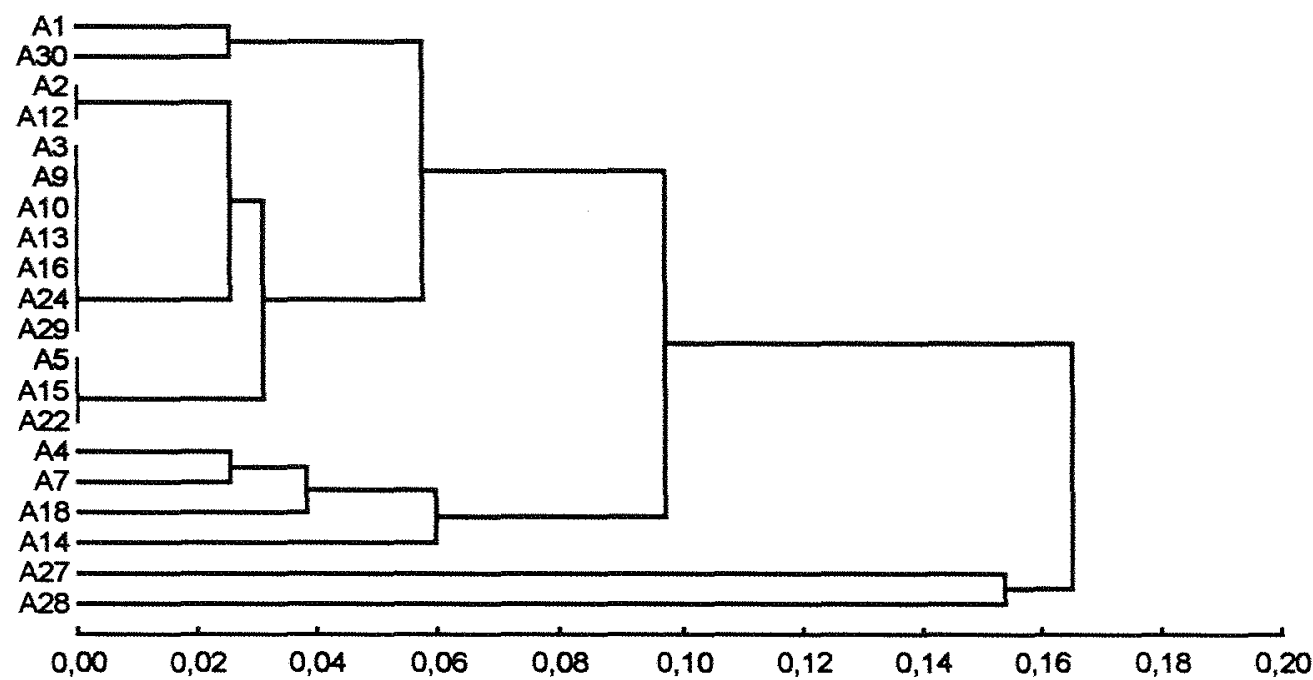

Figura 40. Agrupamento, através do método de UPGMA, das amostras de etnovariedades de mandioca de Ariri ,1 roça 1, utilizando a matriz de dissimilaridades genéticas.

\section{Dendrograma para 12 individuos (Ariti 1 roça 2)}

UPGMA

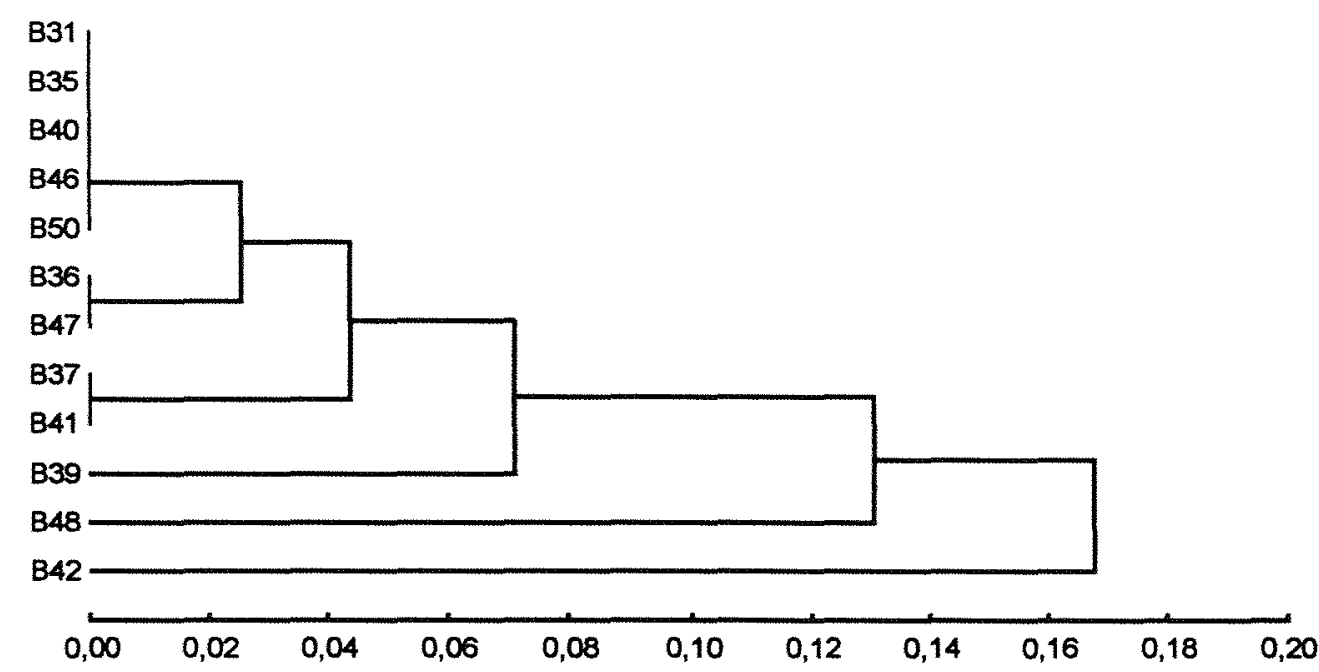

Figura 41. Agrupamento, através do método de UPGMA, das amostras de etnovariedades de mandioca de Ariri 1 roça 2 , utilizando a matriz de dissimilaridades genéticas. 
Dendrograma para 17 individuos (Ariri 1 roça3)

UPGMA

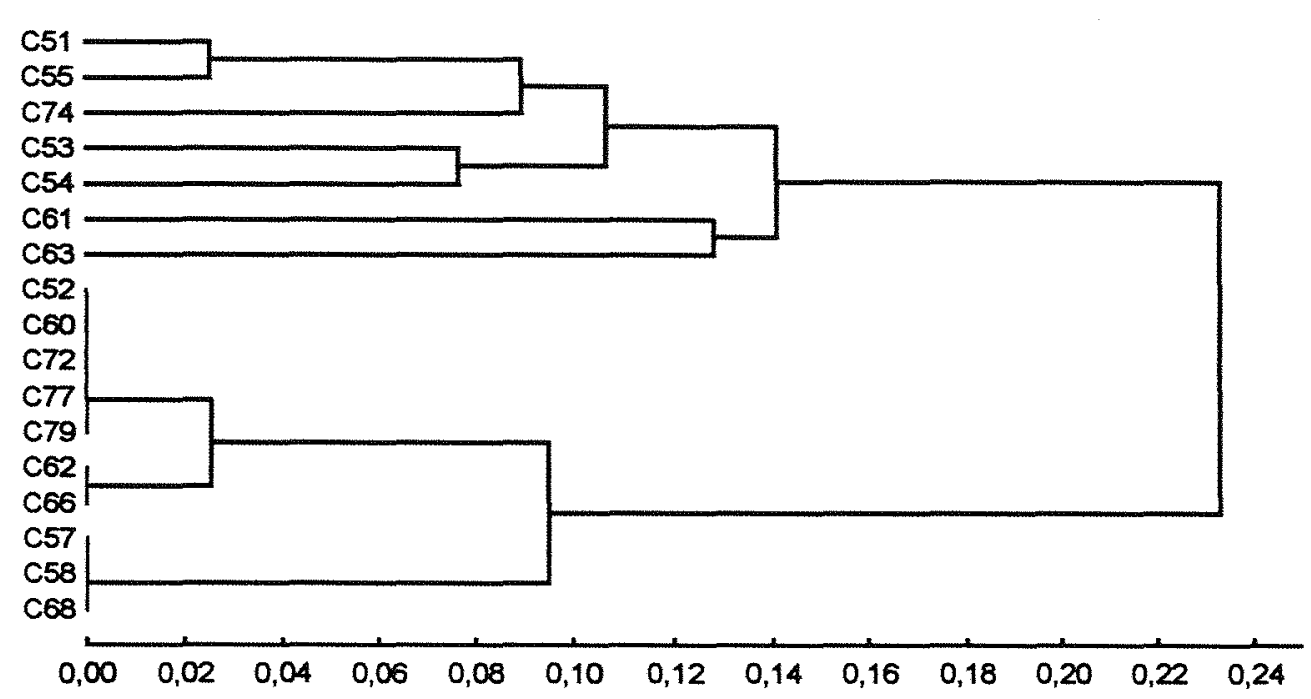

Figura 42. Agrupamento, através do método de UPGMA, das amostras de etnovariedades de mandioca de Ariri 1 roça 3, utilizando a matriz de dissimilaridades genéticas.

É importante ressaltar que as roças de Ariril são representativas, principalmente a roça 1 , de variedades obtidas de diferentes localidades nas proximidades da comunidade de Ariri, reunidas para a fundação de novas roças e de reinicio do plantio de mandioca pelo agricultor.

Nestas roças de Ariril é possivel inferir sobre a existência de grupos, subgrupos e de genótipos diferenciados, entretanto com este tipo de amostragem apenas se confirma que o agricultor subestima a variabilidade presente.

As amostragens onde o agricultor identificou cada amostra individualmente, Ariri2 e Praia Grande, são mais ilustrativas, no que se refere à precisão da identificação (Figuras 43 a 50), e demostram 
também a eficiência no uso do método de agrupamento para os indivíduos amostrados.

No caso das roças de Ariri 2 (Figuras 43 a 46 ) observa-se claramente que existe acurácia quanto ao grupo, ou família de genótipos, a qual ele denomina por um nome varietal, distinguindo-se o grupo das "cascudas", das "cascudas grandes", dos "aipins-guaçus", das "mandipoias", e do "aipim-amarelo".

Dendrograma para 32 individuos (Ariri 2 roça 1)

UPGMA

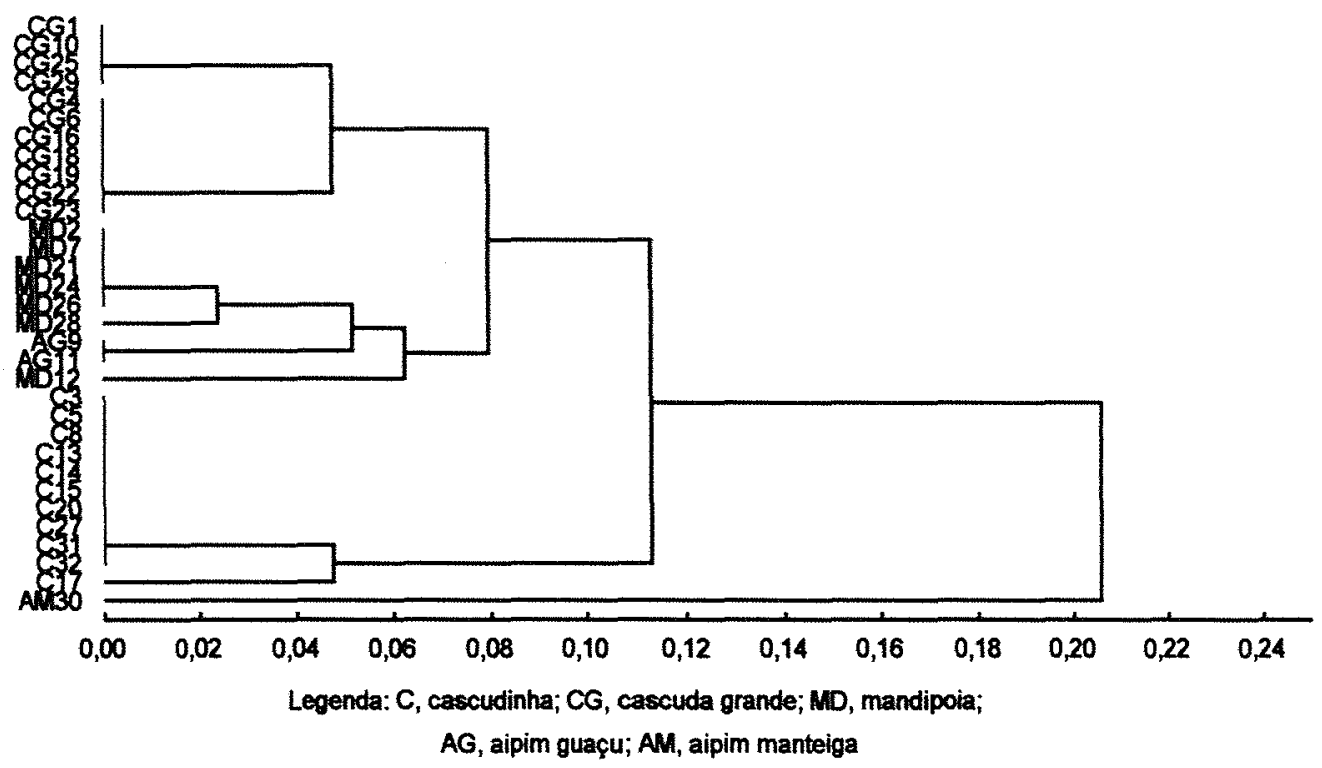

Figura 43. Agrupamento, através do método de UPGMA, das amostras de etnovariedades de mandioca de Ariri 2 roça 1, utilizando a matriz de dissimilaridades genéticas. 
Dendrograma para 15 indivíduos (Ariri 2 roça 2)

UPGMA

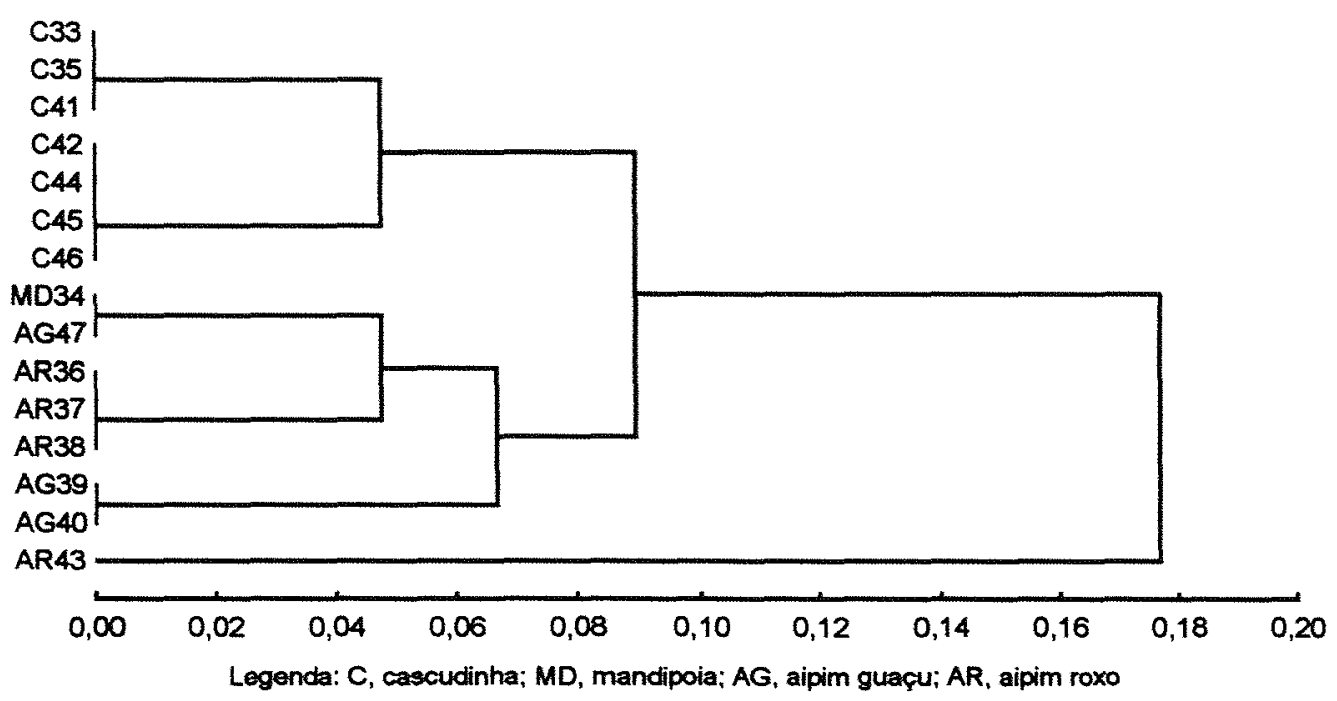

Figura 44. Agrupamento através do método de UPGMA, das amostras de etnovariedades de mandioca de Ariri 2, roça 2, utilizando a matriz de dissimilaridades genéticas.

Dendrograma para 20 individuos (Ariri 2 roça 3)

UPGMA

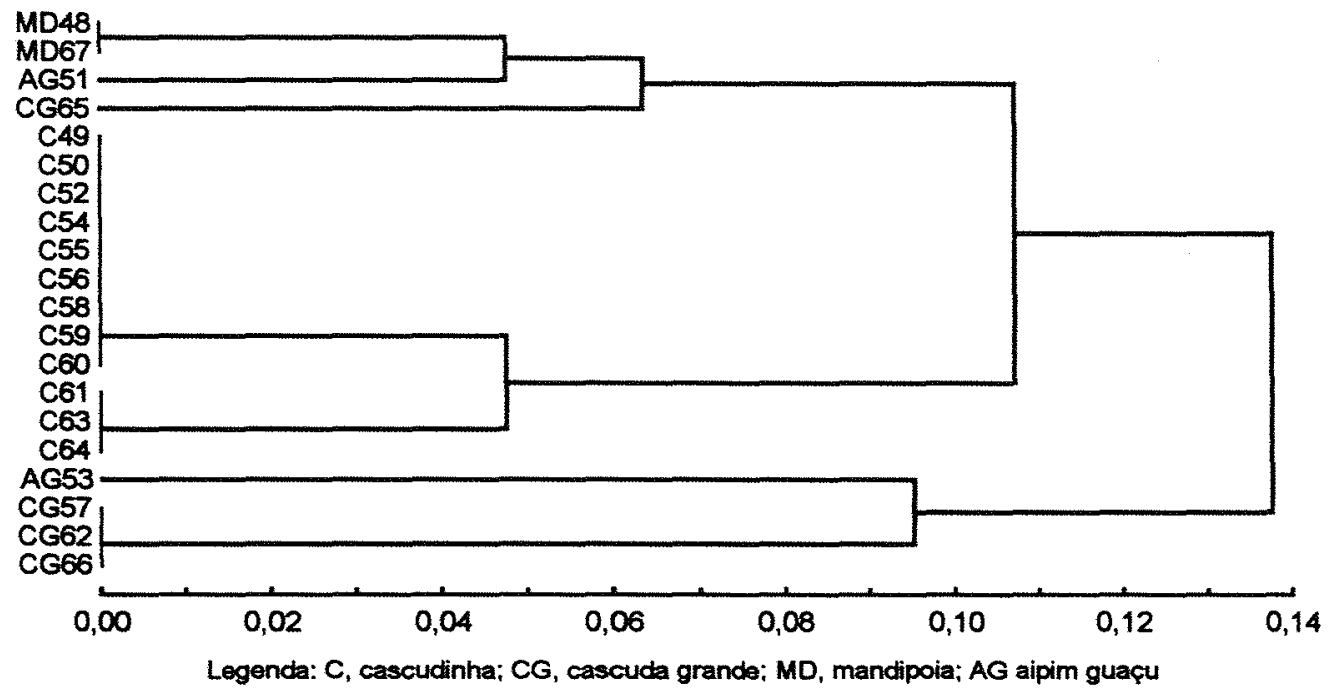

Figura 45. Agrupamento, através do método de UPGMA, das amostras de etnovariedades de mandioca de Ariri 2, roça 3, utilizando a matriz de dissimilaridades genéticas. 
Dendrograma para 20 individuos de Ariri 2 roça 3

Ligação Completa

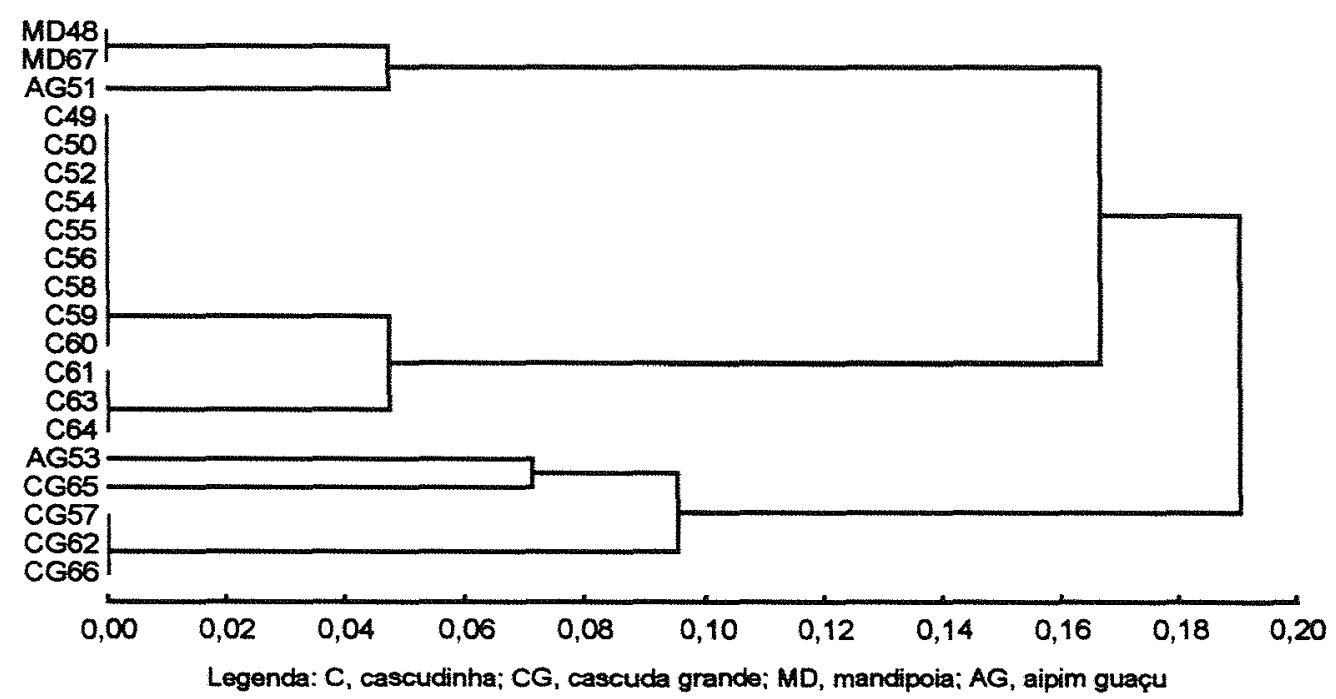

Figura 46. Agrupamento, através do método de ligação completa, das amostras de etnovariedades de mandioca de Ariri 2, roça 3, utilizando a matriz de dissimilaridades genéticas.

Observa-se que em todas as roças existem mais de um genótipo para cada variedade. Na roça 1 de Ariri 2 (Figura 43) a etnovariedade "cascuda grande" é composta por dois genótipos diferentes assim como "cascudinha". A etnovariedade "mandipóia" é composta por três, sendo as outras representadas apenas por um genótipo. Ao todo são 9 genótipos enquanto foram identificados 5 etnovariedades no conjunto amostral.

Na roça 2 de Ariri 2, foram identificados 4 etnovariedades, entretanto existem 6 genótipos diferentes, sendo que as variedades "cascudinha", "aipim roxo", e "aipim guaçu" apresentam mais de um genótipo (Figura 44). Na roça 3 deste ano observa-se um panorama semelhante (Figura 45), com as etnovariedades "cascudinha", "cascuda grande", e "aipim guaçu", apresentando mais de um 
genótipo. Como existe coerência na morfologia de cada etnovariedade estudada na roças de Ariri 2. pode-se afirmar que estes genótipos compōe as etnovariedades como populações heterogêneas.

Com algumas exceções, como as amostras MDl2 na roça 1 de Ariri2, e CG65 na roça 3 de Ariri2, que mostraram mudanças de agrupamento a partir da mudança de método aglomerativo (Figuras 43,44 e 45 ) todas as amostras de Ariri2 são agrupadas dentro de grupos coerentes. No caso da roça 2, Figura 44, existe uma amostra de "mandipóia" (MD34) que deve ser um clone de "aipim-guaçu", ou viceversa, sugerindo que neste caso houve erro de identificação. Nas outras roças deste local, conclusões deste tipo não são seguras.

Porém, fica evidente que para o conjunto de bandas analisadas, e em comparação entre os grupos formados, "mandipóia" é muito semelhante a "aipim guaçu", o que levaria a possíveis erros na identificação. As etnovariedades "cascuda grande", "mandipóia" e "aipim guaçu" são muito próximas entre si, como indicado pela análise morfológica, e muito próximas quanto aos coeficientes de similaridade.

Semelhanças às ocorrências das roças de Ariri2 são evidenciadas nas roças de Praia Grande (Figuras de 47 a 50), com as etnovariedades "vassourinha", "vassourão", e "pão do céu". Nas roças deste local, foi observada maior confusão na identificação, como observado na roça 1, Figura 47, que mostra também que o número de genótipos é maior dentro de uma roça, 12 ao todo. Os grupos de genótipos, em Praia Grande, são mais diferenciados, isto é, os coeficientes de similaridades genética têm maior amplitude (Tabela 12). Como a nomenclatura local indica, as etnovariedades "vassourinha" e "vassourão", realmente 
mostraram ser diferentes, apresentando genótipos distintos.

Na amostragem executada em Praia Grande também se constata que o agricultor subestima a variabilidade presente na roça. Era ele quem coletava e identificava as amostras agrupando-as de acordo com nome etnovarietal. Pelo que se observa em todas as roças estudadas deste local, independente do coletor, são considerados indivíduos geneticamente diferentes, como membros de uma mesma variedade. Nas roças onde é plantado apenas uma etnovariedade isso fica bem evidenciado, como nas roças 2,3 e 4 (Figuras 48,49 e 50).

Dendrograma apenas dos fenótipos isoenzimáticos

Praia Grande (roça 1) - UPGMA

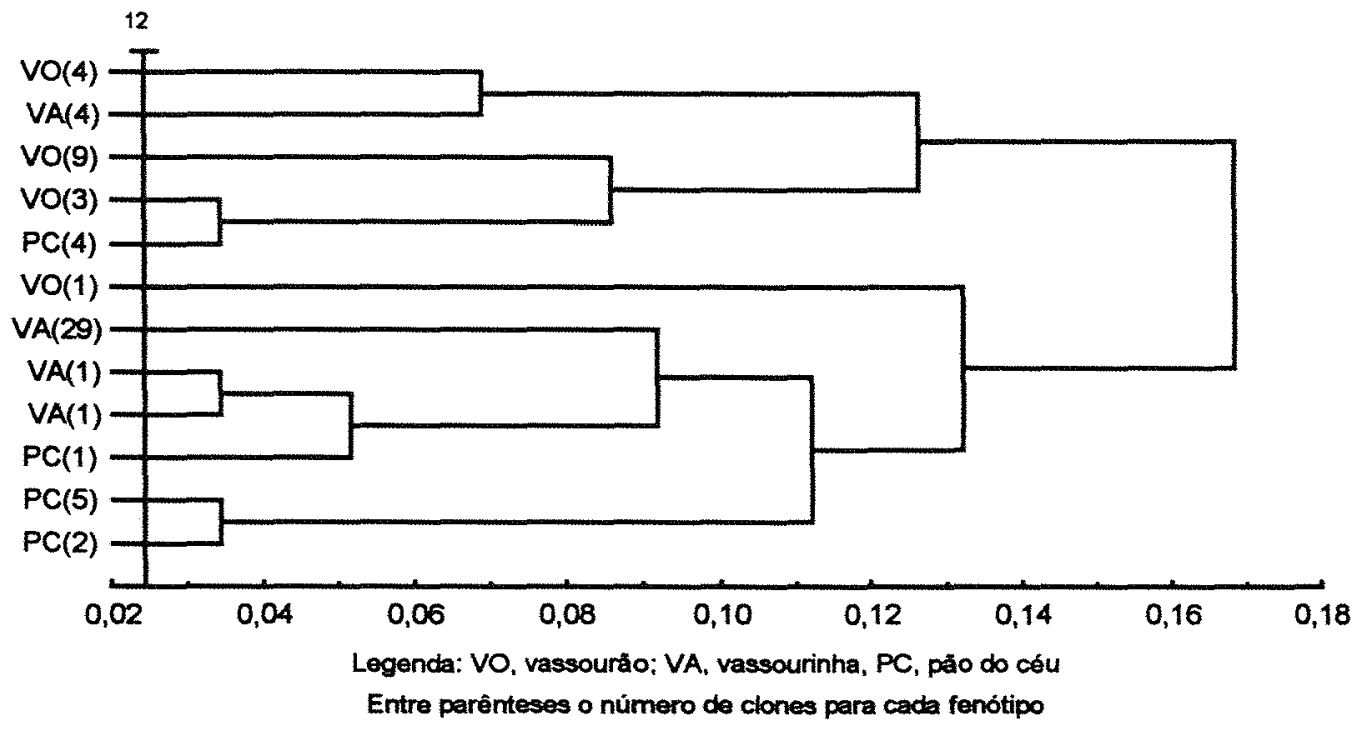

Figura 47. Agrupamento, através do método de UPGMA, das amostras de etnovariedades de mandioca de Praia Grande roça 1, utilizando a matriz de dissimilaridades genéticas. 


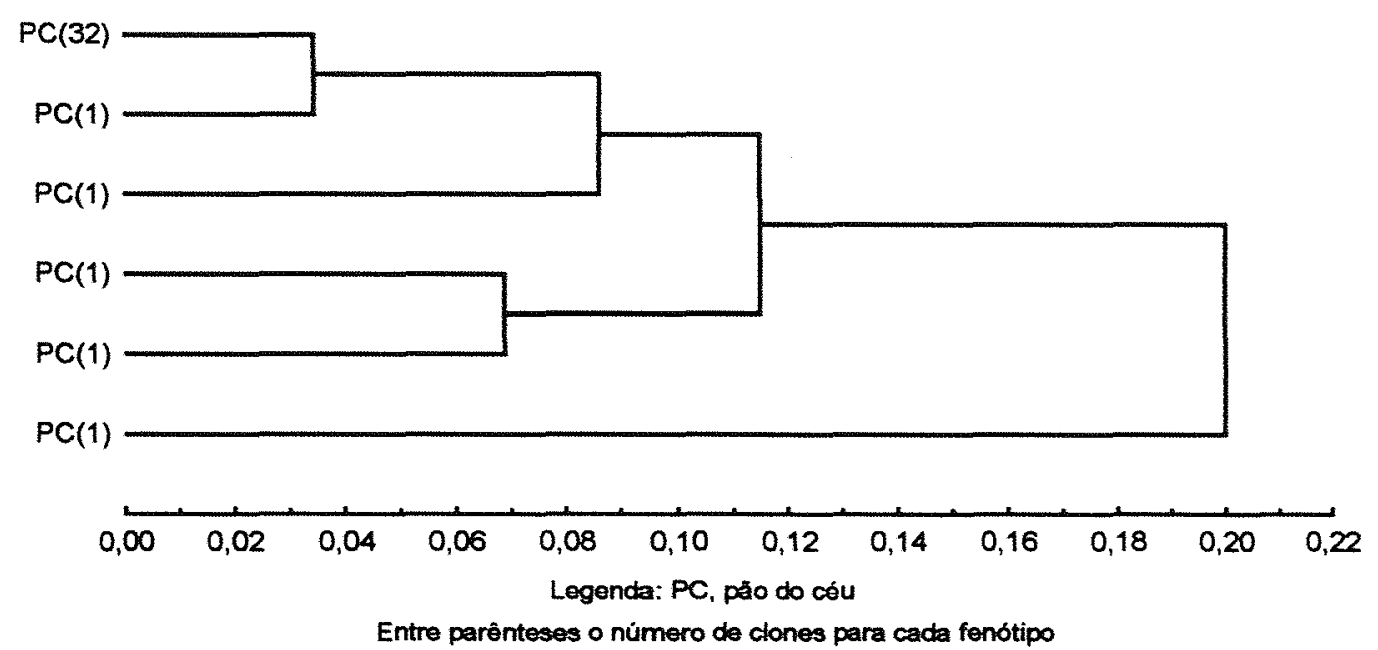

Figura 48. Agrupamento, através do método de UPGMA, das amostras de etnovariedades de mandioca de Praia Grande roça 2, utilizando a matriz de dissimilaridades genéticas.

Dendrograma apenas para os fenótipos isoenzimáticos

Praia Grande (roça3) - UPGMA

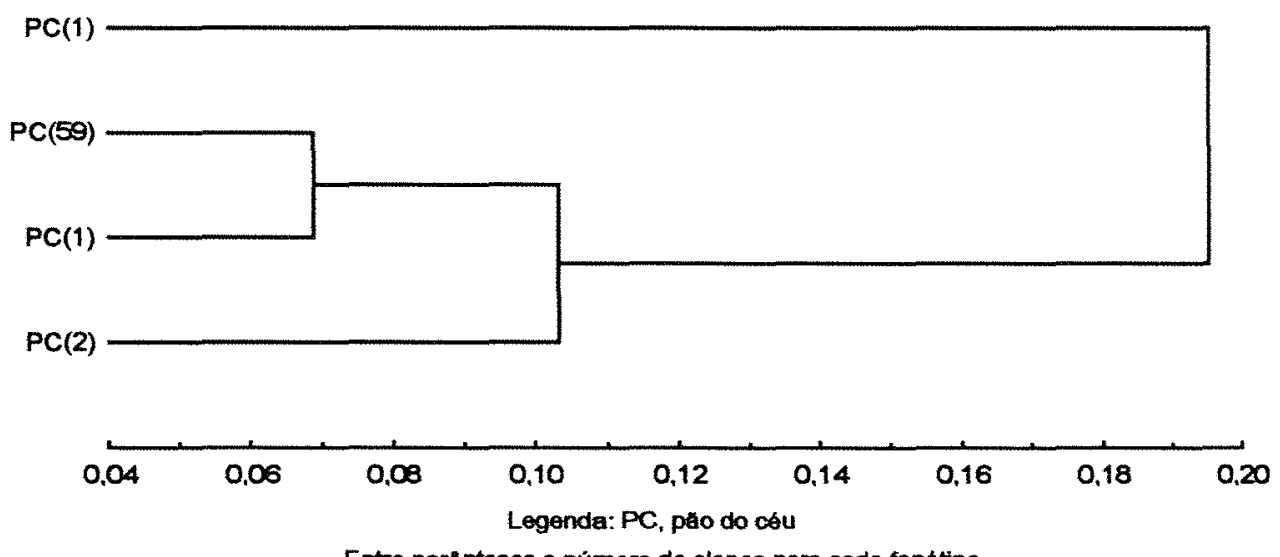

Entre perenteses o nümero de clones pare cada fenótipo

Figura 49. Agrupamento, através do método de UPGMA, das amostras de etnovariedades de mandioca de Praia Grande roça 3, utilizando a matriz de dissimilaridades genéticas. 


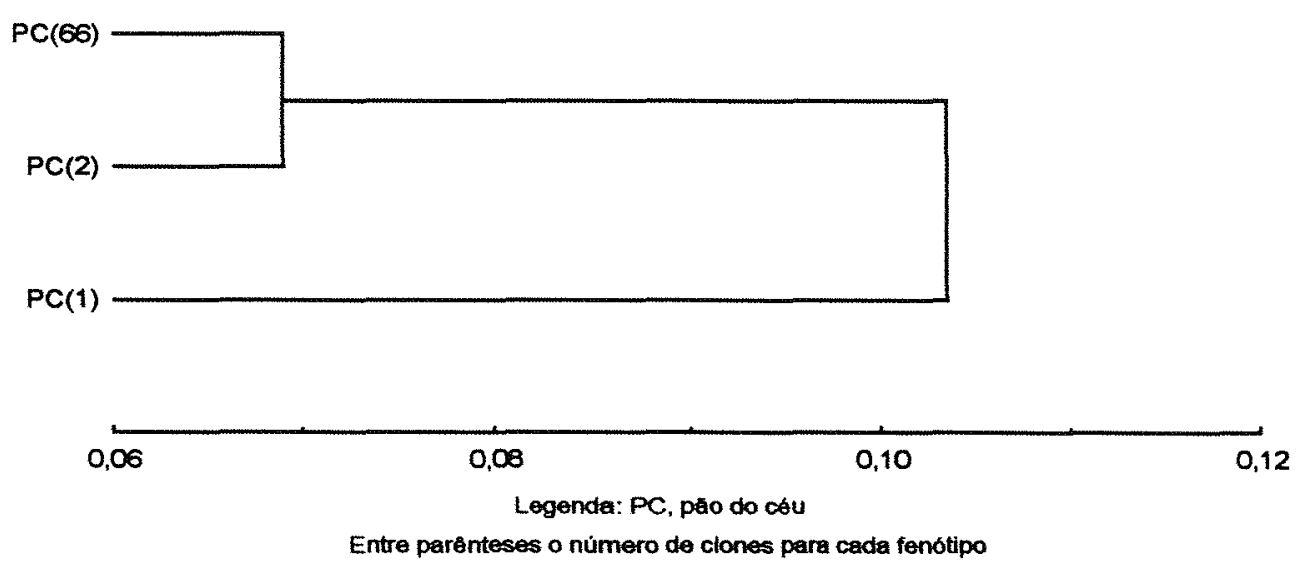

Figura 50. Agrupamento, através do método de UPGMA, das amostras de etnovariedades de mandioca de Praia Grande roça 4, utilizando a matriz de dissimilaridades genéticas.

Através desta análise, fica claro que o agricultor depara-se com variações morfológicas que não refletem as diferenças isoenzimáticas, isto é, não refletem os genótipos diferentes (Figuras 43 a 46, e 10 a 14). Entretanto o agricultor agrupa os genótipos isoenzimaticamente diferentes dentro de famílias coerentes. Isso demonstra que o agricultor se depara com uma população de genótipos que guardam semelhança morfológica, mas que não são todos idênticos do ponto de vista genético. Ele é capaz de identificar as etnovariedades como conjuntos, ou grupos, de indivíduos idênticos, mas maneja inconscientemente cada etnovariedade que compõe uma população de genótipos diferentes.

Apesar de existir certa congruência entre o número de grupos "morfológicos" e "isoenzimáticos", isso nāo quer dizer que exista relação 
direta da diferenciaçāo morfológica com a diferenciação enzimática. Os resultados obtidos pela correlação de Mantel, entre as matrizes de distância obtidas a partir de dados morfológicos e as matrizes de dissimilaridade obtidas a partir de dados de presença e ausência de bandas isoenzimáticas, são bastante variáveis para as roças estudadas (Tabela 13). Isso indica que não se pode dizer que as diferenças genéticas estão diretamente refletidas na morfologia. As roças de Arin 2 mostraram correlações maiores que as de Ariril, talvez porque o número de genótipos seja menor e haja maior precisão nas estimativas de distância baseadas nos caracteres morfológicos. As roças le 3 de Ariri 1 apresentaram os menores valores, sendo que foram estas roças que apresentaram pouca estrutura na diferenciação de grupos. Logo esta ocorrência deve ter influenciado os resultados da correlação de Mantel. Colombo (1997) encontrou valores inferiores a estes, usando o mesmo teste, ao comparar distâncias morfológicas com distâncias genéticas resultantes de dados de RAPD. 
Tabela 13. Resultados do teste de Mantel para todas as roças de Ariri.

\begin{tabular}{lccccccccc}
\hline Local & $\mathrm{N}$ & $\mathrm{r}$ & $\mathrm{Z}$ & $\begin{array}{c}\text { Mantel } \\
\text { t-test }\end{array}$ & $\mathrm{p}$ & $<\mathrm{Z}$ & $=\mathrm{Z}$ & $>\mathrm{Z}$ & $\mathrm{p}[\mathrm{Zr}=\mathrm{ZO}]^{*}$ \\
\hline Ar1 R1 & 190 & 0.386 & 19.343 & 2.994 & 0.9986 & 4999 & 0 & 1 & 0.0004 \\
Ar1 R2 & 66 & 0.904 & 7.755 & 3.331 & 0.9996 & 4998 & 0 & 2 & 0.0006 \\
Ar1 R3 & 136 & 0.343 & 28.157 & 3.460 & 0.9997 & 4992 & 0 & 8 & 0.0018 \\
Ar2 R1 & 496 & 0.644 & 63.001 & 7.565 & 1.0000 & 5000 & 0 & 0 & 0.0002 \\
Ar2 R3 & 190 & 0.754 & 23.958 & 6.942 & 1.0000 & 5000 & 0 & 0 & 0.0002 \\
\hline * Zr - Z permutado & & & & & & & \\
Zo-Z observado & & & & & & & & &
\end{tabular}

Logo, pela análise geral dos agrupamentos obtidos, conclui-se que o agricultor subestima a variabilidade presente dentro da roça, conseguindo sucesso na discriminaçāo de grupos, como é evidente até mesmo nas etnovariedades com nomes semelhantes.

\subsubsection{Análise de Coordenadas Principais (PCO)}

A intenção desta análise é melhor visualizar as relações dos grupos formados e dos genótipos dentro dos mesmos. Ela visa complementariedade às análises de agrupamento, importando a estruturaçāo no espaço bi ou tridimensional dos grupos e genótipos baseados nas distâncias entre genótipos dois a dois. Foram executadas apenas para os dados das roças de Ariri 2 , onde foram obtidos os nomes de cada indivíduo e onde foi possivel a análise dos caracteres morfológicos.

Nas Figuras 51, 52 e 53, observa-se a representação bidimensional, considerando as duas primeiras coordenadas principais. Os autovalores extraídos da análise podem ser observados no Apêndice 29.

Na Figura 51, que representa os individuos da roça 1 de Ariri 2, a primeira coordenada é responsável pela separação de dois grupos mais 
distintamente representados. Neste caso os indivíduos nomeados como "cascudinha" (C). ficam separados do segundo grupo composto por "mandipoia" (MD), "aipim roxo" (AR), e "aipim amarelo" (AM). Os indivíduos da etnovariedade "cascuda grande" (CG) ficam em posição superior, considerando a segunda coordenada.

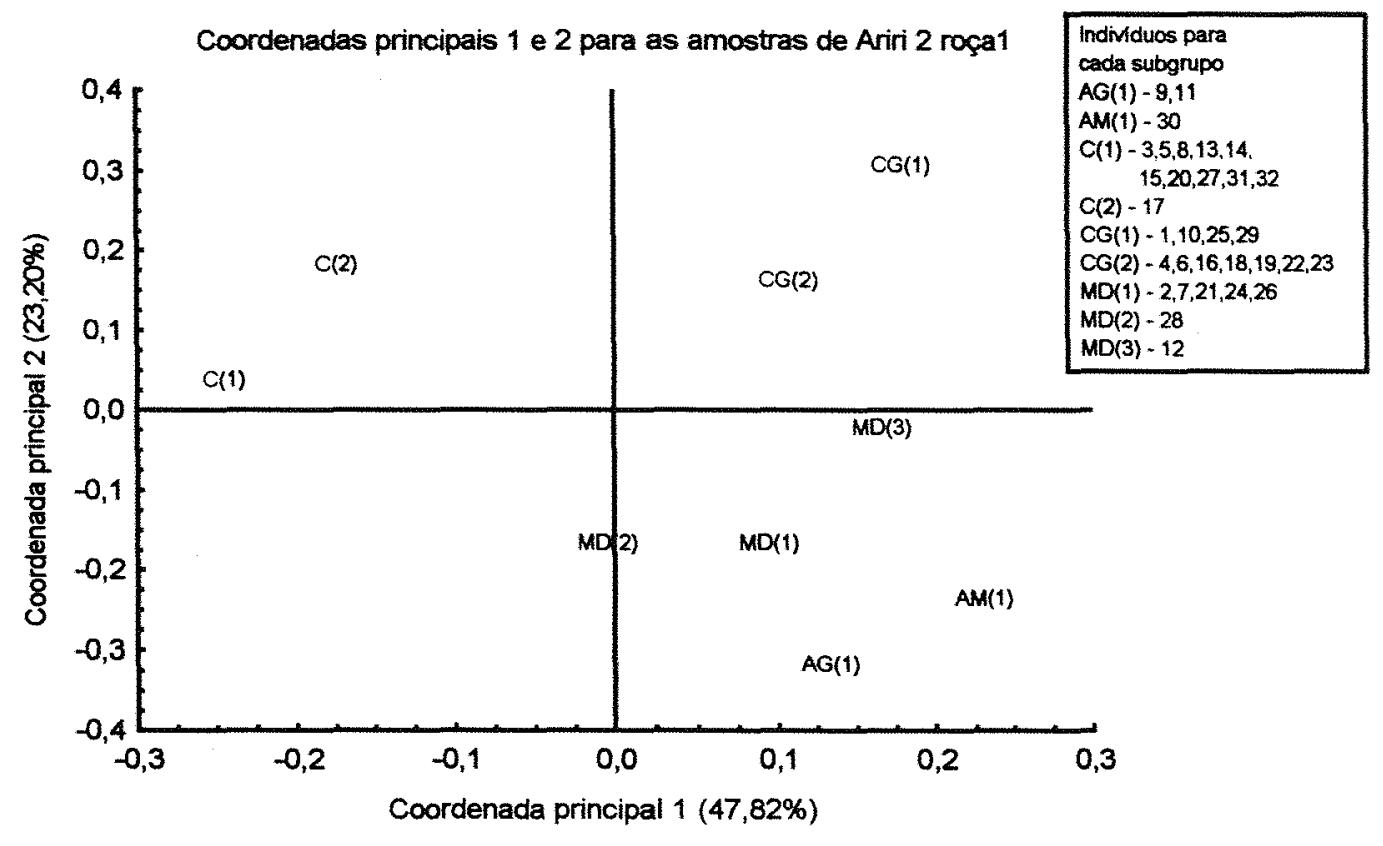

Figura 51. Escores provenientes da análise de coordenadas principais, caculada a partir das similaridades genéticas de 32 amostras de etnovariedades de mandioca de Ariri 2, roça 1. Considerando as coordenadas 1 e 2 .

Quando se acrescenta a terceira coordenada, observa-se que existem diferenças dentro dos grupos, através dos genótipos com mesmo nome varietal, como para "cascuda grande" (CG) e "cascudinha" (C), Figura 52 . Observa-se também que a etnovariedade "aipim manteiga" se destaca do grupo maior, Figura 52. 
Coordenadas principais 1, 2 e 3 para as amostras de Ariri 2 roça 1

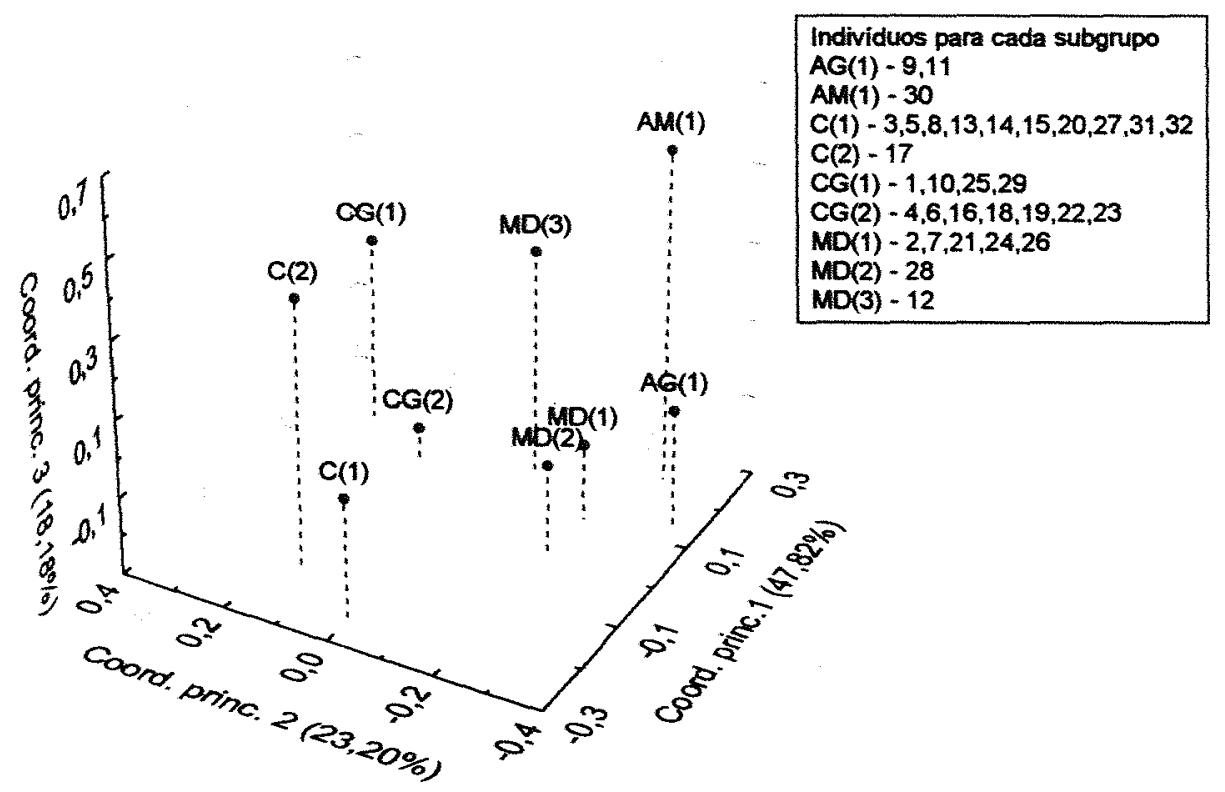

Figura 52. Escores provenientes da análise de coordenadas principais calculada a partir das similaridades genéticas de 32 amostras de etnovariedades de mandioca de Ariri 2, roça 1. Considerando as coordenadas 1,2 e 3.

A mesma diferenciação, que ocorre na roça 1, é observada na roça 2 (Figura 53), quanto à etnovariedade "cascudinha" (C) As duas coordenadas neste caso representam $69,30 \%$ da variação total e fica evidente que 3 clones de um genótipo de "aipim roxo" $A R(2)$, são claramente separados de outros 3 clones do outro genótipo $A R(1)$, formando um pequeno grupo distinto. Novamente a representação tridimensional permite uma melhor visualização dos componentes dos grupos e subgrupos. Quando é acrescentada a terceira coordenada, a diferenciação dos clones de "mandipoia" (MD), e/ou "aipim-guaçu (AG), fica evidente, destacando-os como um subgrupo (Figura 54). 


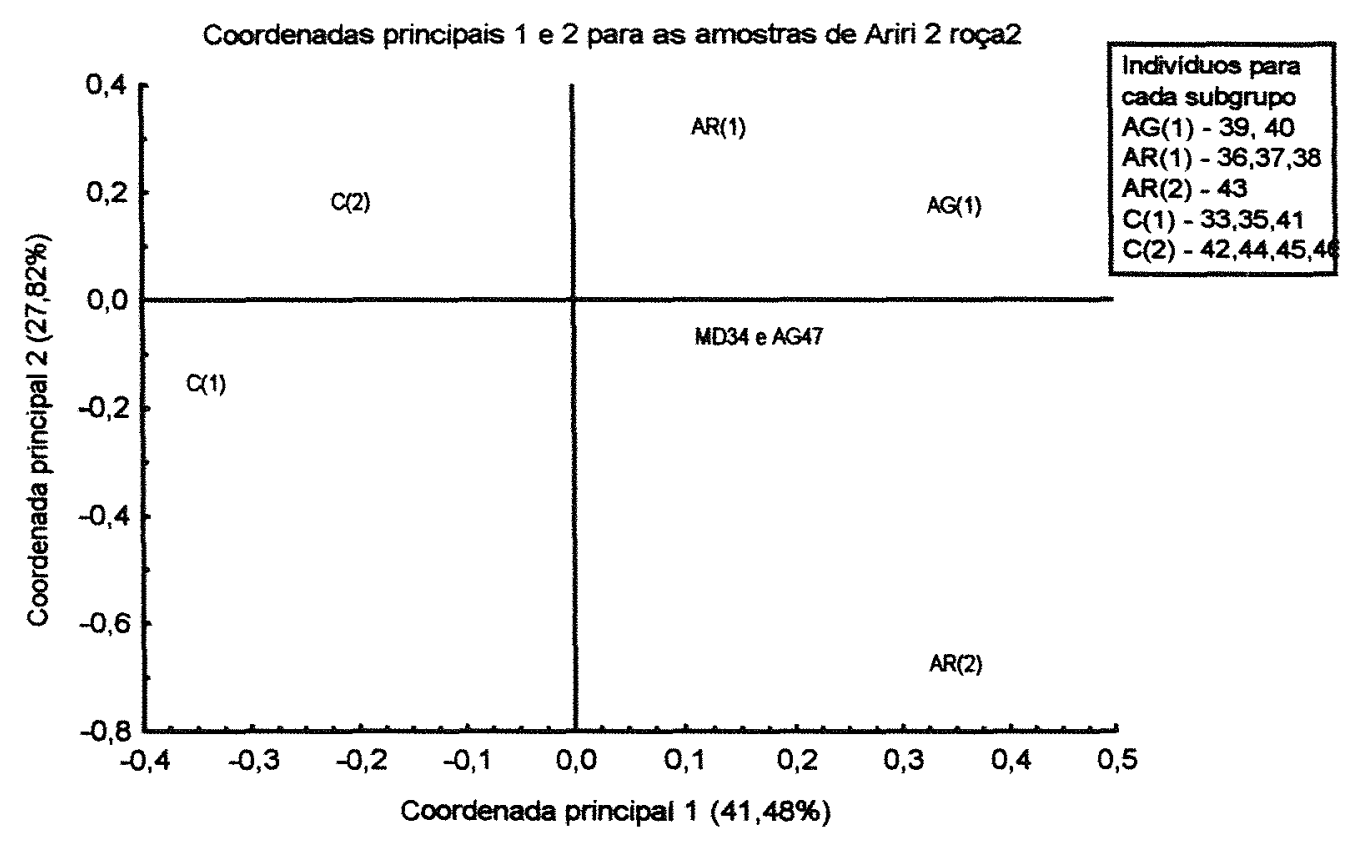

Figura 53. Escores provenientes da análise de coordenadas principais calculada a partir das similaridades genéticas de 13 amostras de etnovariedades de mandioca de Ariri 2, roça 2. Considerando as coordenadas 1 e 2 . 
Coordenadas principais 1, 2 e 3 para as amostras de Ariri 2 roça2

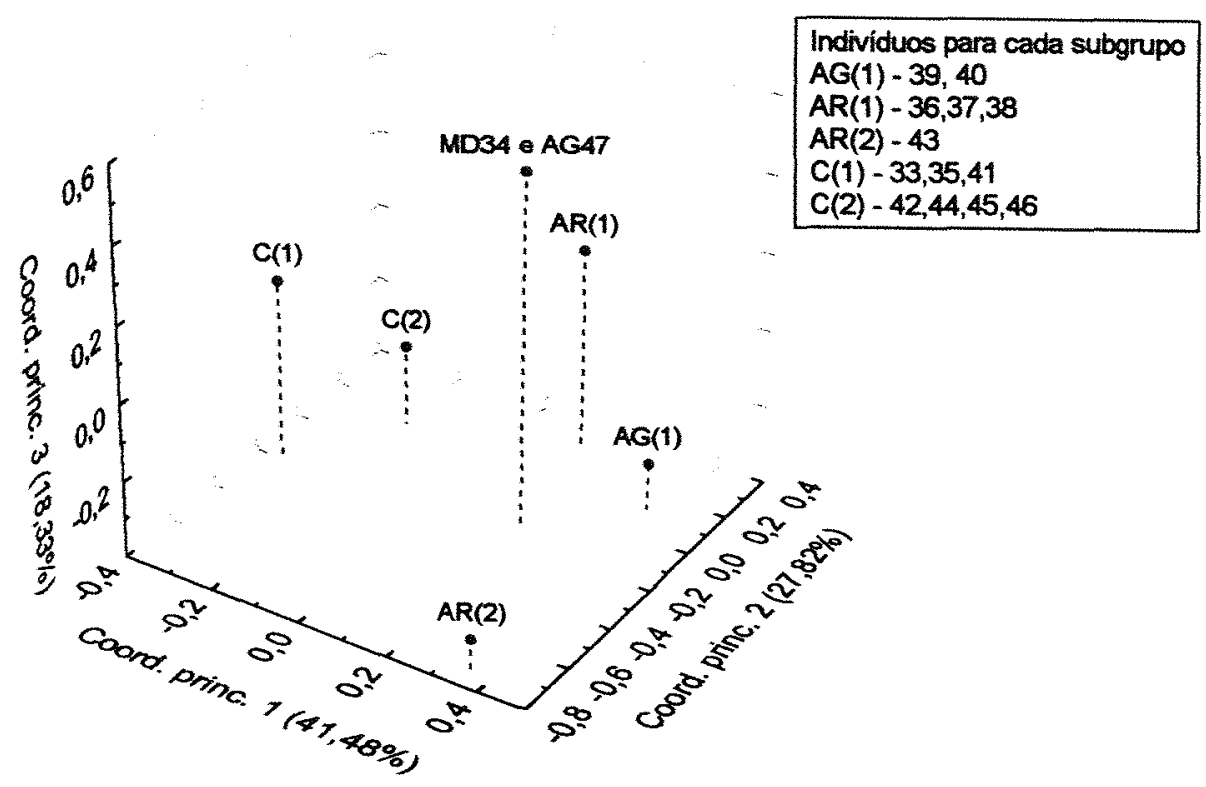

Figura 54. Escores provenientes da análise de coordenadas principais calculada a partir das similaridades genéticas de 13 amostras de etnovariedades de mandioca de Ariri 2, roça 2. Considerando as coordenadas 1,2 e 3.

A Figura 55 representa a roça 3, considerando as duas primeiras coordenadas com $82,47 \%$ da variação total. A primeira coordenada separava novamente os indivíduos de "cascudinha" $(C)$, de dois grupos maiores e mais heterogêneos. Além disso observa-se na Figura 56, que o terceiro eixo, apesar de conter apenas $9,33 \%$ da variaçāo total, é importante na separação dos subgrupos, como os de "cascudinha" (C). 


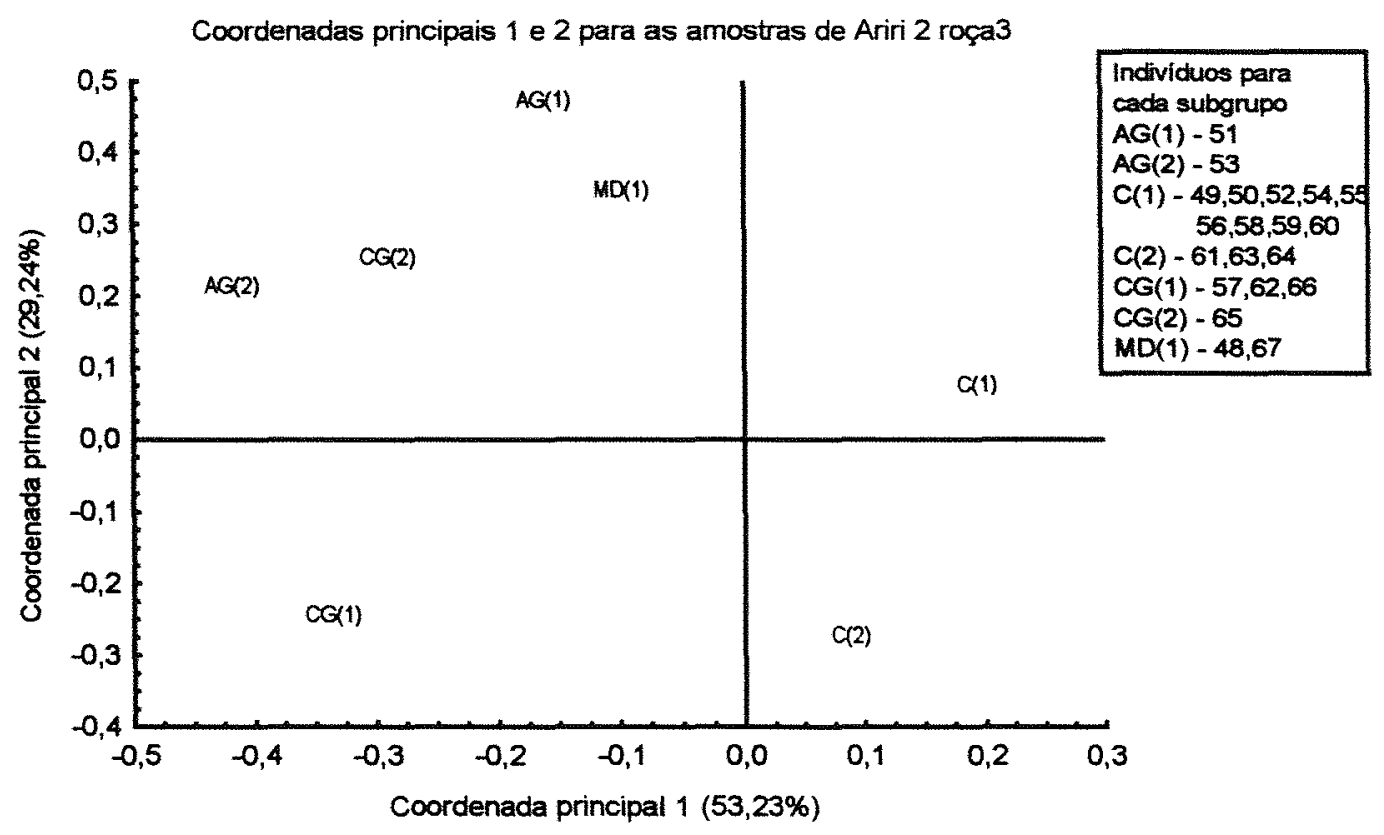

Figura 55. Escores provenientes da análise de coordenadas principais calculada a partir das similaridades genéticas de 20 amostras de etnovariedades de mandioca de Arin 2, roça 3. Considerando as coordenadas 1 e 2 . 
Coordenadas principais 1, 2 e 3 para as amostras de Ariri 2 roça3

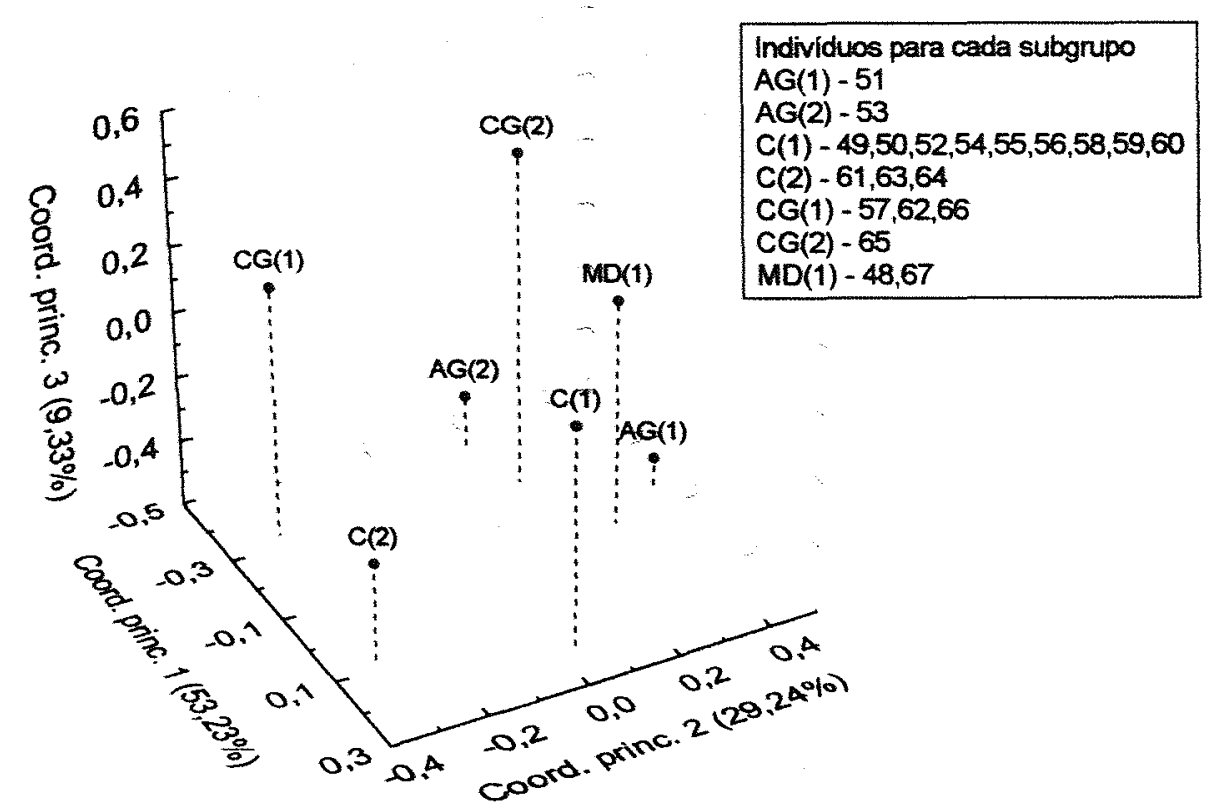

Figura 56. Escores provenientes da análise de coordenadas principais calculada a partir das similaridades genéticas de 20 amostras de etnovariedades de mandioca de Ariri 2, roça 3. Considerando as coordenadas 1,2 e 3.

O uso da representaçāo tridimensional favoreceu a análise pois permitiu a plotagem das primeiras coordenadas que agregam maior porcentagem da variação total. No caso das Figuras 52,54 e 56 são representados $89,20 \%, 87,63 \%$ e $91,8 \%$ da variação total respectivamente.

Como discutido anteriormente, a configuração do dendrograma na roça 3, de Ariri 2, foi afetada pelos diferentes métodos de aglomeração. Pelas análises acima, observa-se as configurações dos agrupamentos a partir das coordenadas principais extraídas das distâncias entre indivíduos (Figuras 55 e 56). Através deste método, ficam evidentes as relações entre os grupos e subgrupos, concordando com o agrupamento obtido a partir de "ligação completa". 
4.4 Dinâmica evolutiva da mandioca em roças de agricultura tradicional autóctone

Cury (1993) considera que a população de mandioca cultivada na roça é a população referencial sobre a qual atuam os processos evolutivos. Conjugando evidências como a reprodução artificial da mandioca via propagação vegetativa, o fato de que a espécie não perdeu a capacidade de se reproduzir sexuadamente e que indivíduos de gerações de autopolinização apresentam forte depressão por endogamia (Hershey \& Amaya, 1984 e Kawano et al., 1978), o autor propōe um modelo de dinâmica evolutiva para a espécie. Neste modelo, o surgimento de variabilidade seria função da interação entre mutação, migração, hibridaçāo interespecífica, e principalmente hibridação intraespecífica, com os processos de manejo agrícola.

Em estudos subsequentes, como Faraldo (1995) e Peroni \& Martins (1995), foram acumuladas evidências para o modelo de dinâmica evolutiva da mandioca proposto por Cury (1993). Indicações diretas e indiretas de germinação de sementes em roças reutilizadas depois de até 25 anos de pousio foram observadas por Peroni \& Martins (1995). Neste estudo, os autores puderam observar que em roças de agricultura itinerante da região sul do estado de São Paulo, os agricultores identificam aqueles indivíduos originados de germinação de semente a partir de observações diferenciadas: 1) Pelo aparecimento de plantas de mandioca logo após a abertura da roça, e antes mesmo do plantio; 2) Pelo aparecimento de um individuo fora do espaçamento padrão estabelecido, após ter plantado as variedades na roça; 3) Pela morfologia da planta ser diferente das variedades cultivadas 
tradicionalmente, entretanto o agricultor muitas vezes considera que a planta é idêntica morfologicamente a alguma variedade que possui, o que faz sentido pois os caracteres observáveis da morfologia podem nāo expressar as diferenças genéticas; 4) Pelo formato da raiz, isto é, se o agricultor está em dúvida se o indivíduo é originado de semente, arranca-o para observar a forma da raiz, e sendo esta "um pião", isto é, pivotante, conclui que a planta germinou de semente. Raiz pivotante em mandioca é característica de germinação, em contraste com o desenvolvimento de várias raízes a partir de gemas do caule, como ocorre na propagação vegetativa. Ficou evidenciado por este estudo que o agricultor tem conhecimento da possibilidade de cruzamentos entre etnovariedades de mandioca ao ponto de explicar o aparecimento de individuos "estranhos" na roça, e que as sementes produzidas podem ficar no banco de sementes, germinando quando sujeitas a condições apropriadas. Assim, papel fundamental teria o banco de sementes de mandioca na dinâmica evolutiva da espécie, pois possibilitaria fluxo de gens no tempo. Quando novas roças são abertas nos locais de antigos cultivos, há chance de ocorrer cruzamentos entre indivíduos plantados pelo agricultor e aqueles germinados na roça, "representantes" de conjuntos gênicos mais antigos.

Indicaçōes de mesma natureza sāo relatados também por Boster (1985) e Salick et al. (1997). Freitas (1997)8 relata que, entre os índios das tribos Waurá e Yawalapiti no Parque Indígena do Xingu (Brasil), os indivíduos de mandioca germinados a partir de semente e que são identificados como tal, são experimentados, avaliados, posteriormente 
multiplicados e incorporados ao conjunto de cultivares, recebendo a designação de "que veio do céu". Sambatti (1998) relata o mesmo tipo de ocorrência em roças de agricultura itinerante na região de Ubatuba (SP), entretanto a nomeação é dada em função de alguma característica particular do indivíduo. Boster (1985) coloca que indivíduos originados a partir de semente são nomeados como "yagkuj" (flor) ou "tsapaínu" (broto), destacando as partes reprodutivas na nomenclatura. Amorozo (1996) encontrou entre os anos de 1992 e 1993, em roças de agricultura tradicional na regiāo de Santo Antônio do Leverger, Mato Grosso, 44 mandiocas "nascidas" de semente, entretanto muitos destes individuos foram perdidos e apenas 2 deles continuaram a ser plantados. Segundo a autora, quando o resultado do cruzamento entre variedades é diferente dos tipos que existem no sítio, o agricultor tenta traçar a "ascendência" daquele recombinante, comparando suas características com as características das possiveis variedades que o originaram.

O modelo de Cury (1993) foi continuamente revisto e reformulado (Figura 57), incorporando o banco de sementes como um fator chave, que funciona como um "reservatório" natural de recombinantes. A Tabela 14 resume as relações da Figura 57 e demonstra as relações do manejo agrícola com os componentes de história vital da espécie. A atuação humana é um fator perturbatório favorecendo processos colonizadores, reprodutivos, de geração, dispersão e manutenção da variabilidade genética. A roça, com seu limite físico e populacional claramente definidos (Figuras 58 e 59), é o local onde as interaçōes homem-planta cultivada ocorrem, e portanto pode ser considerada a

\footnotetext{
9 Julliano Sambatti, comunicação pessoal, Laboratório de Genética Ecológica do Departamento de Genética de ESALQ/USP
} 
unidade evolutiva básica. Nela atuarāo os fatores de seleçāo natural, associados à seleção perceptiva e consciente do agricultor (Figura 51), tanto sobre uma variabilidade "observada", claramente discriminada sob a forma de etnovariedades, como sobre uma variabilidade que é subestimada, como ficou evidenciado no presente estudo. 


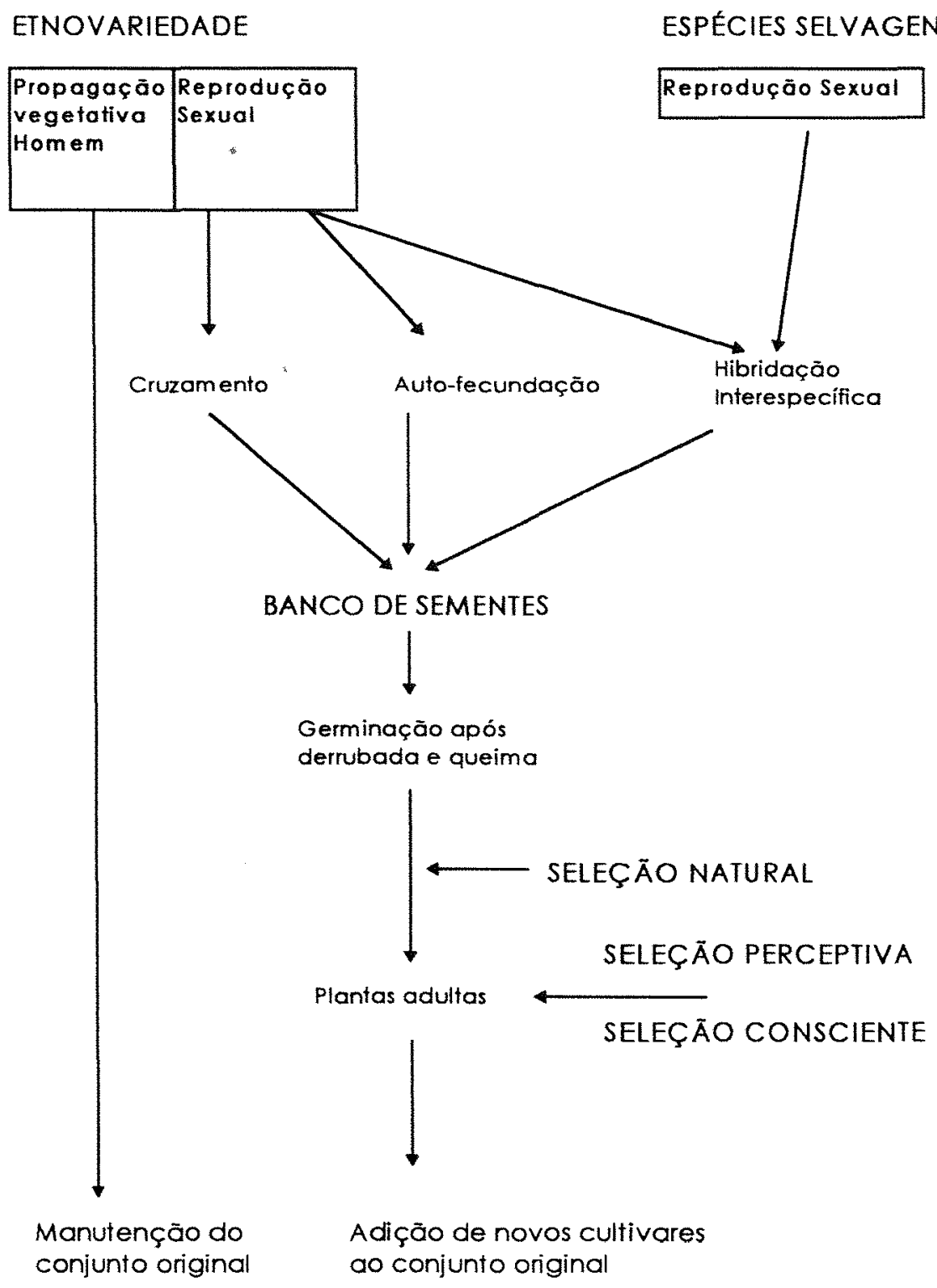

Figura 57. Modelo de Dinâmica Evolutiva da Mandioca ${ }^{10}$

${ }^{10}$ Segundo Dr Paulo Sodero Martins, Laboratório de Genética Ecológica - Comunicação pessoal, modificado a partir de Cury (1993) 
Tabela 14. Relações entre manejo tradicional e eventos de dinâmica evolutiva da mandioca"1

\begin{tabular}{ll}
\hline \multicolumn{1}{c}{ MANEJO } & \multicolumn{1}{c}{ EVENTO } \\
\hline Abertura da roça & $\begin{array}{l}\text { Perturbação estimulando } \\
\text { colonização }\end{array}$ \\
Plantio da roça & $\begin{array}{l}\text { Estabelecimento de população } \\
\text { com limites definidos (unidade } \\
\text { evolutiva) } \\
\text { Habilidade de combinação } \\
\text { ecológica }\end{array}$ \\
Plantio de diferentes espécies & $\begin{array}{l}\text { Favorecimento de inter- } \\
\text { cruzamento(hibridação) }\end{array}$ \\
Plantio de diferentes variedades & $\begin{array}{l}\text { Hibridação introgressiva } \\
\text { Controle brando de colonizadores }\end{array}$ \\
Ausência de colheita de sementes & $\begin{array}{l}\text { Dispersão natural e formação de } \\
\text { banco de sementes }\end{array}$ \\
Retorno às áreas de roça antiga & $\begin{array}{l}\text { Germinação de sementes do } \\
\text { banco }\end{array}$ \\
Propagação vegetativa & $\begin{array}{l}\text { Manutenção dos genótipos } \\
\text { originais, fixação de mutantes }\end{array}$
\end{tabular}

11 Segundo Dr Paulo Sodero Martins, Laboratório de Genética Ecológica Comunicação pessoal 


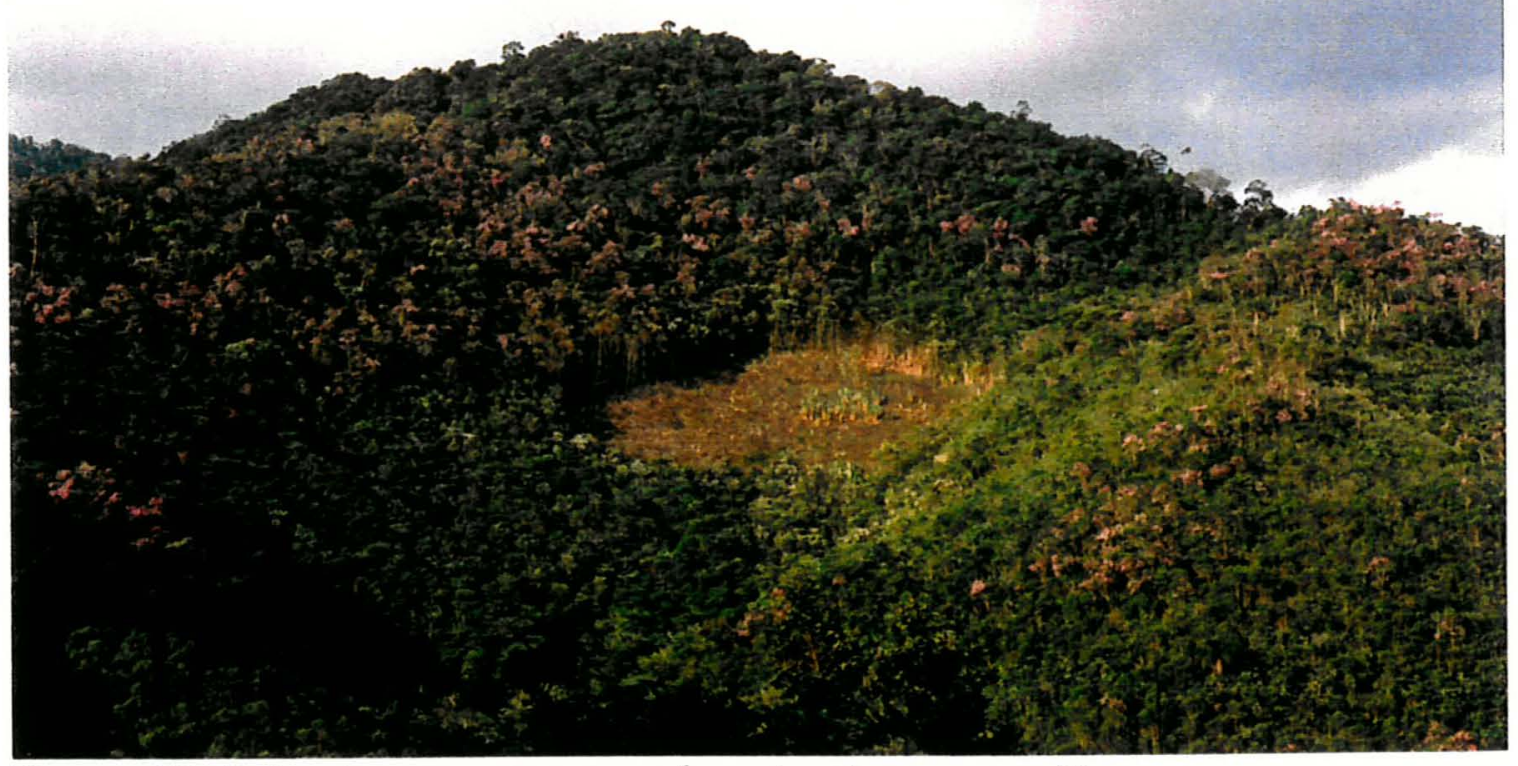

Figura 58. Foto de uma roça recém aberta para cultivo.

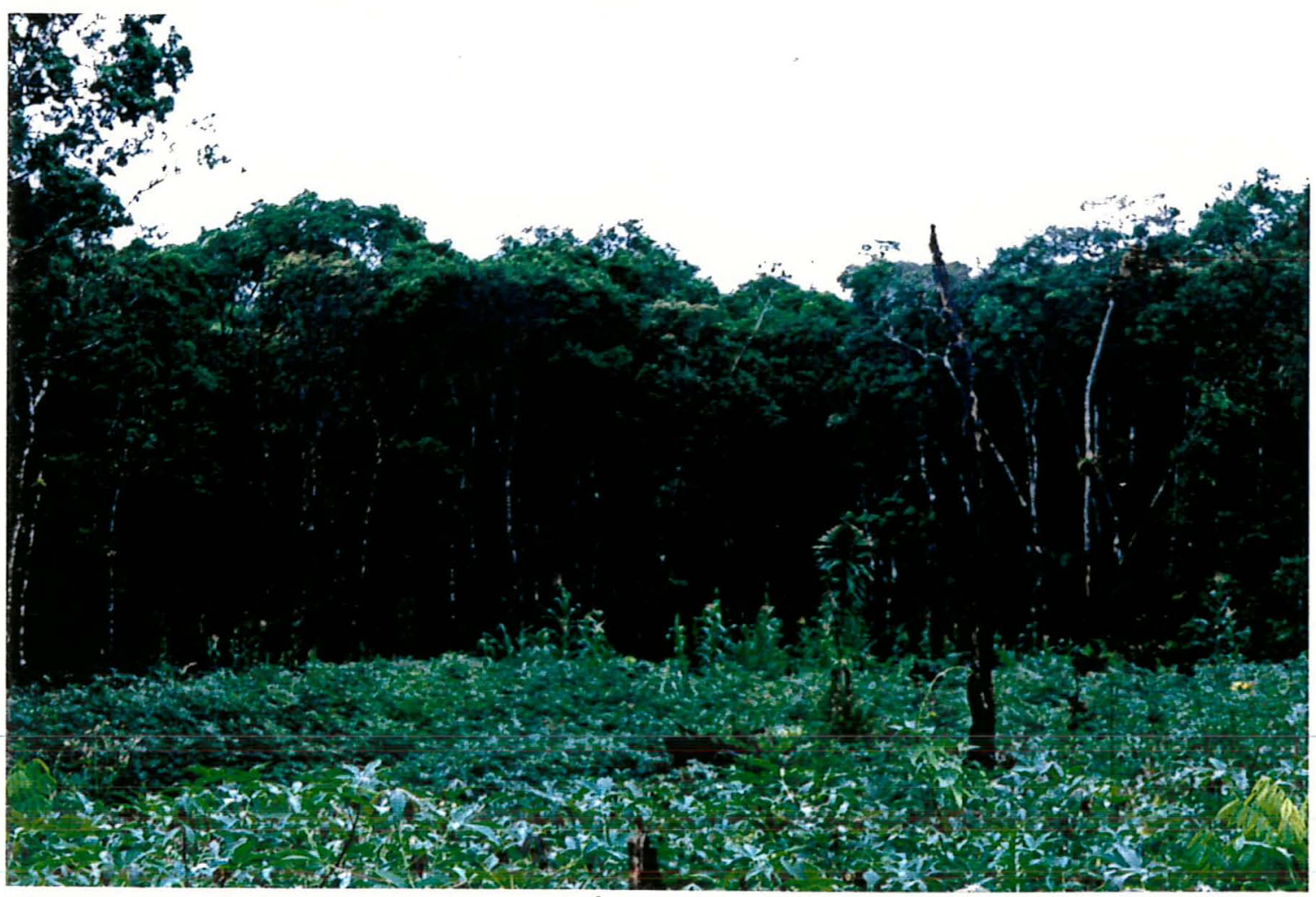

Figura 59. Foto da roça no início do cultivo, com a população de mandioca em destaque. 
Evidências de subestimação da variabilidade genética intra-roça, em agricultura autóctone, foram claramente observadas por Quiros et al. (1990), estudando o cultivo da batata (Solanum tuberosum) na região dos Andes peruanos. Estes autores mostraram que pode ocorrer alto grau de associação entre o sistema de classificação usado pelos agricultores para denominar suas variedades e os fenótipos eletroforéticos. Entretanto, destacam que a nomeação fenotípica pode expressar fielmente a variação genotípica correspondente ou subestimar a variabilidade existente no campo, com repetição de nomes para variedades diferentes genotipicamente.

Apesar do número de agricultores que participaram das amostragens não ter sido tão grande quanto os que Quiros et al. (1990) analisaram, no presente estudo ficou claro que o agricultor consegue identificar a "família" de genótipos classificada de acordo com nomenclatura própria, mas não distingue indivíduos geneticamente diferentes "dentro" da variedade, e que apresentam semelhanças na morfologia.

Do ponto de vista etnotaxonômico, fica evidente que existe uma classificação estruturada, confirmando o que foi amplamente discutido por Boster (1984). Entretanto, pode-se afirmar que em nivel intraespecífico, a identificação de recombinantes com grande proximidade entre si, pelo agricultor, não é possivel, o que favorece a manutenção de variabilidade intra varietal dentro da roça. Quando estes recombinantes expressam morfologicamente as diferenças genéticas, eles podem ser reconhecidos, nomeados e incluídos no conjunto original como uma variedade distinta, mas aqueles que não são identificáveis podem permanecer na roça compondo 
etnovariedades que são populaçōes geneticamente heterogêneas. A origem desta variabilidade genotípica está ligada então aos processos sexuais operantes entre as etnovariedades, intrinsicamente associados ao manejo agrícola.

Estes processos sexuais seriam a principal fonte destes indivíduos novos, que não são identificados, ou se identificados são renomeados. Os resultados analisados no presente estudo indicam também a grande proximidade genotípica entre genótipos com o mesmo nome, e sugerem que além de ocorrer cruzamentos entre etnovariedades, parece ocorrer cruzamentos entre clones de um mesma etnovariedade. Isso caracterizaria uma autofecundação já que os indivíduos são geneticamente idênticos. De qualquer forma é o processo sexual que atua na geração de variabilidade.

Considerando as possibilidades de cruzamentos dentro da roça, tanto entre etnovariedades (hibridação intraespecifica) como entre clones, observamos que os resultados obtidos estão coerentes com o modelo de dinâmica evolutiva, quando este "prevê" que cruzamentos entre efnovariedades e entre clones podem ocorrer em nível de roça, e que isso é possivel graças a intervenção humana.

Se por um lado a roça é a fonte geradora de variabilidade, a comunidade parece funcionar como um "sistema tampão", onde trocas são constantes e onde existe "circulação" de etnovariedades suprindo falhas e perdas ocasionais de cada agricultor. Isso também é confirmado por Amorozo (1996), segundo esta autora, a comunidade funciona como um "fundo" de germoplasma, havendo interdependência grande dos agricultores individuais, e em última análise, "as partes existem por causa do todo". Pela própria descrição da 
origem das etnovariedades e do processo de continua classificação relatado pelo agricultor em Ariri, há indicaçōes de que a hibridação intraepecifica intra-roça deve atuar conjuntamente com processos migratórios.

Segundo Boster (1984), variedades introduzidas nas comunidades são mais facilmente identificáveis no início do processo de introdução, pelas discrepâncias que elas apresentam em relaçāo ao conjunto já existente e pela capacidade de discriminação do agricultor. No caso de Ariri, observamos que existem diferenças na identificação nos dois anos estudados, mas não se pode afirmar com segurança se isto foi decorrência da maior capacidade de diferenciação de um informante em relação ao outro, pois o nivel o tipo de amostragem foi diferente. Mesmo assim, disto pode-se inferir sobre dois niveis de identificaçāo das etnovariedades, lembrando que as roças de 1995 ainda representam as reintroduçōes de variedades no local.

O primeiro nível de identificação envolve as distinções entre etnovariedades coletadas nas duas amostragens em Ariri. O principal informante em 1995 relata que "cascuda" é a variedade que predomina. Este agricultor identifica a maior parte dos indivíduos como "cascuda", sem distinção entre "cascudas grandes" e "cascudinhas", e muito menos entre os diferentes genótipos que compōem cada etnovariedade. Apesar do uso de métodos diferentes de amostragem, ficou claro que existem dois grupos morfologicamante distintos: "cascuda grande" e "cascudinha", entre os outros grupos formados, porém apenas o agricultor mais experiente, no ano de 1997, teve capacidade de distiguilos. Apesar desta aparente confusão na distinção e da maior capacidade de identificação de um agricultor em relação ao outro, 
todas as outras variedades foram identificadas em grupos coerentes, ocorrendo grande acurácia em nível intervarietal, ou, sinonimamente, em nivel intraespecifico.

Nenhum dos informantes entretanto conseguiu separar os genótipos "dentro" das etnovariedades o que leva ao segundo nível de identificação, o qual depende da expressão genotípica, indo além do conhecimento do agricultor e de sua capacidade de diferenciação. As discrepâncias observáveis pelo agricultor dependem então da correlação entre as diferenças genéticas e a expressão fenotípica do novo genótipo. Pelos resultados obtidos ficou claro que é dado o mesmo nome para genótipos diferentes quando estes são praticamente idênticos.

Diversos autores buscam encontrar "regras" universais de taxonomia, ou de classificação, que existiriam tanta na ciência ocidental como no conhecimento empírico tradicional. Existe ampla discussão entre a "visão utilitária" e a "visão cognitiva" na organização taxonômica de organismos por populaçōes autóctones. Entretanto, do ponto de vista intravarietal, esta dicotomia não faz sentido, já que as descontinuidades morfológicas dependem da expressão genética, e fatores cognitivos e utilitários estão envolvidos conjuntamente. 


\section{CONCLUSÕES}

1) As roças estudadas refletem a herança agrícola indígena, caracterizada pelo cultivo de elevada diversidade inter e intraespecífica e por grande complexidade da forma de manejo.

2) As formas de amostragem tiveram eficiências diferentes, sendo que a coleta totalmente ao acaso sem identificação de cada amostra, mostrou-se ineficiente para o estabelecimento de relações fenéticas seguras. As coletas ao acaso, com e sem interferencia do agricultor, permitiram um detalhamento maior e mais seguro da diversidade.

3) A avaliação da morfologia executada "in situ", foi de grande utilidade na diferenciação de etnovariedades, mostrando ser viável em pequenas roças que apresentam homogeneidade quanto a idade de plantio.

4) As etnovariedades são compostas por genótipos diferentes, porém com grande semelhança morfológica. Desta forma, dentro da roça uma etnovariedade pode ser considerada como uma "família" de genótipos.

5) Os agricultores diferenciam coerentemente as etnovariedades através da morfologia, entretanto, não distinguem os genótipos 
diferentes "dentro" das etnovariedades e que apresentam grande semelhança morfológica. Logo foi comprovado que a variabilidade de mandioca é subestimada nas roças estudadas.

6) A origem destes indivíduos novos está relacionada aos processos sexuais, principalmente à hibridação intraespecífica. A manutenção de variedades plantadas conjuntamente favorece os cruzamentos, sendo que presença de banco de sementes corrobora esta conclusão.

7) Coletas de germoplasma de mandioca feitas tradicionalmente, onde se coleta apenas uma amostra de cada clone identificado pelo agricultor, podem ser consideradas subamostragens. Recomenda-se que estas coletas sejam feitas considerando as roças como unidades amostrais e que se combine amostragem ao acaso com identificação dentro da roça.

8) Os processos de geração de variabilidade são dinâmicos, em decorrência da interação dos processos de manejo humano, com os componentes de história vital da espécie em questão.

9) A manutenção, e sobretudo a amplificação da variabilidade, só será possivel se estes sistemas agrícolas tiverem continuidade. A amplificação da variabilidade de mandioca é um processo dinâmico, e isso torna premente a necessidade de encontrar alternativas que integrem estes agricultores numa economia de mercado, mas que permitam a continuidade de seus cultivos. 
REFERÊNCIAS BIBLIOGRÁFICAS

ALLEM, A.C. The origin of Manihot esculenta Crantz (Euphorbiaceae). Genetic Resources and Crop Evolution, v.41, p.133-150, 1994.

ALFENAS, A.C.; PETERS, I.; BRUNE, W.; PASSADOR, G.C. Eletroforese de Proteínas e isoenzimas de fungos e essências florestais. Viçosa: UFV, 1991. 242p.

ALCORN, J.B. Indigenous agroforestry strategies meeting farmers' needs. New York: Columbia University Press, 1990. cap. 9, p. 141-151: Steps toward sustanaible use of the Amazon Rain Forest.

ALMEIDA, E. Diversidade genética de espécies cultivadas em áreas de agricultura tradicional de Mata Atlântica do estado de São Paulo. Piracicaba: ESALQ, 1997. 55p. (Relatório final).

ALTIERI, M.A.; MERRICK, M.A. In situ conservation of crop genetic resources through maintenance of traditional farming systems. Economic Botany, v.41, p.86-96, 1987.

ALTIERI, M.A.; ANDERSON, M.K. Peasant Farming systems, agricultural modernization, and the conservation of crop genetic resources in Latin America. 
AMOROZO, M.C.M. Sistema de agricultura camponesa em Santo António do Leverger, Mato Grosso, Brasil. São Paulo, 1996. 274p. Tese Faculdade de filosofia, letras e ciências humanas, Universidade de São Paulo.

AMURRIO, J.M. et al. Evaluation of Pisum sativum landraces from the Northwest of the Iberian peninsula and their breeding value. Euphytica, v.66, n.1-2, p.1-110, 1993.

BENNET, B.C. Plants and people of the amazonian rainforests. Bioscience, v.42, n.8, p.599-607, 1992.

BENZ, B.F.; SANCHEZ-VELÁSQUEZ, L.R.; SANTANA-MICHEL, F.J. Ecology and ethnobotany of Zea diploperennis. preliminary investigation. Maydica, v.35, n.2, p. 85-98, 1990.

BERLIN, B. Ethnobiological classification: principles of categorization of plants and animals in traditional societies. Princeton: University Press, 1992. $327 p$.

BERLIN, B. The relation of folk systematics to biological classification and nomenclature. Annual Review of Ecology and Systematics, v.4, p.259-271, 1973.

BORSOI FILHO, J.L. Variabilidade isoenzimática e divergência genética de seis cultivares de mandioca (Manihot esculenta Crantz). Viçosa, 1995. 52p. Dissertação (M.S.) - Universidade Federal de Viçosa. 
BOSTER, J.S. A comparison of diversity of Jivaroan garden with that of tropical forest. Human Ecology, v.11, n.1,1983.

BOSTER, J.S. Classification, cultivation, and selection of Aguaruna cultivars of Manihot esculenta (Euphorbiaceae). Advances in Economic Botany, v.1, p. 34-47, 1984.

BOSTER, J.S. Selection for perceptual distinctiveness. Evidence from Aguaruna cultivars. Economic Botany, v.38, p.310-325, 1985.

BREWER, G.L.; SING, C.F. An Introdution to isozyme techniques. New York: Academic Press, 1970. 186p.

BRONDANI, C. Variaçāo isoenzimática de três espécies do gênero Manihot (Euphorbiaceae) relacionadas morfologicamente à mandioca (Manihot esculenta Crantz). Pesquisa Agropecuária Brasileira, v.31, n.4, p.287-289, 1996.

BROWN, A.H.D. Isozymes, plant population genetic structure, and genetic conservation. Theoretical and Applied Genetics, v.52, p.145157. 1978.

BRÜCHER, H. Useful plants of neotropical origin (and their wild relatives). 1992. $245 p$.

BRUSH, S.B. In situ conservation of landraces in Centers of Crop Diversity. Crop Science, v.35, n.2, p. 346-354, 1995. 
BRUSH, S.B. Ethnoecology, biodiversity, and madernization in Andean potato agriculture. Journal of Ethnobiology, v.12, n. 2, p.161-185, 1992.

BRUSH, S.B. A farmer-based approch to conserving crop germplasm. Economic Botany, v.45, p.153-166, 1991.

BRUSH, S.B.; CARNEY, H.J.; HUAMÁN, Z. Dynamics of Andean Potato Agriculture. Economic Botany, v. 35, n. 1, p.70-88, 1981.

CANDIDO, A.C. Os parceiros do Rio Bonito: estudo sobre o caipira paulista e a transformação dos seus meios de vida. 4.ed. São Paulo: Livraria Duas Cidades, 1977. 284p.

CARNEIRO, R.L. The cultivation of manioc among the Kuikuru of the upper Xingú. In: HAMES, E.O.; VICKERS, W.T. (Ed.) Adaptative responses of native Amazonians. New York: Academic Press, 1983. cap. 3, p. 65-111.

CARVALHO , C.G.P. Hibridação interespecífica da mandioca (Manihot esculenta Crantz) com espécies afins. Viçosa, 1995. 56p. Dissertação (M.S.) - Universidade Federal de Viçosa.

CECCARELLI , S.; GRANDO, S. Environment of selection on and type of germplasm in barley breeding for low-yielding conditions. Euphytica, v.57, n.3, p.207-220, 1991. 
CECCARELLI, S. Specific adaptation and breeding for marginal conditions. Euphytica, v.77, n.3, p.205-219, 1994.

CHATFIELD, C.; COLLINS, A.J. Introduction to multivariate analysis. London: Chapman \& Hall, 1980. $246 \mathrm{p}$.

CHELIAK, W.M.; PITEL, J.A. Techniques for starch gel electrophoresis of enzymes from forest tree species. Patawawa National Forestry Institute, Canadian Forestry Service Information Report PI-X-42, 49p, 1984.

CHERNELA, J.M. Os cultivares de mandioca na área do Uaupés (Tukâno). In: RIBEIRO, D. (Ed.) Suma etnológica brasileira. 2. ed. Petrópolis: Vozes, 1987. v. 1, cap.9, p.51-158.

CLAYTON, J.W.; TRETIAK, D.N. Amine-citrate buffers for pH control in starch gel eletrophoresis. Journal of the Fisheries Research Board of Canada, n.29, p.1169-1172, 1972.

CLÉMENT D. Why is taxonomy utilitarian? Journal of Ethnobiology, v.1, n.15, p.1-44, 1995.

CLEVELAND, D.A.; SOLERI, D.; SMITH, S.E. Do folk crop varieties have a role in sustainable agriculture?. BioScience, v. 44, n.11, p.740-751, 1994. 
COLOMBO, C. Étude de la diversité génétique de maniocs américains (Manihot esculenta Crantz) par les marqueurs moléculaires (RAPD et AfLP). Montpellier, 1997. 145p. Thèse (Doctorat) - École Nationale Superieure Agronomique de Montpellier.

CURY, R. Dinâmica evolutiva e caracterização de germoplasma de mandioca (Manihot esculenta, Crantz) na agricultura autóctone. Piracicaba, 1993. 103p. Dissertação (Mestrado) - Escola Superior de Agricultura "Luiz de Queiroz", Universidade de São Paulo.

DEAN, W. A botânica e a política imperial: introduçāo e adaptaçāo de plantas no Brasil colonial e imperial. São Paulo: Instituto de Estudos Avançados, USP, 1992. 21 p (IEA. Coleção Documentos)

DIAS, J.S. Genetic diversity and taxonomy at Portuguese trouchuda cabbage and Galega kale landraces using isozyme analysis. Euphytica, v.75, n.3, p. 221-230, 1994.

DORP, M.van. et al. Collecting landraces of soyabean, maize, cassava and sweet potato in indonesia and studying the associated local knowledge. Plant Genetic Resources Newsletter, n.93, p.45-48, 1993.

DUFOUR, D. Use of tropical rainforests by native amazonians. BioScience, v.40, n.9, p. 652-659, 1990.

DUN, G.; EVERIT, B. An introdution to mathematical taxonomy. London: Cambridge University Press, 1980. 151p. 
EDEN, M.J. Swidden cultivation in forest and savanna in lowland southwest Papua New Guinea. Human Ecology, v. 21, n. 2, p.145-166, 1993.

EDEN, M.J. Crop diversity in tropical swidden cultivation: comparative data from Colombia and Papua New Guinea. Agriculture, Ecosystems and Environment, v.20, p.127-136, 1988.

ESCRIBANO, $F$. et al. Diversity in agronomical traits in common bean population from Northwestern Spain. Euphytica, v.76, n.1-2, p.1-6, 1994.

FARALDO, M.I.F. Caracterização isoenzimática e diversidade de etnovariedades de mandioca (Manihot esculenta Crantz). Piracicaba, 1995. 91p. Dissertação (Mestrado) - Escola Superior de Agricultura "Luiz de Queiroz", Universidade de São Paulo.

FENSTER, E.J.; SORHANNUS, U. On the measurement of morphological rates of evolution: a review. Evolutionary Biology, v.25, p.375-405, 1991.

GADGIL, M.; BERKERS, F.; FOLKE, C. Indigenous knowledge for biodiversity conservation. Ambio, v. 22, n² 2-3, p. 151-156, 1993.

GEPTS, J. The use of molecular and biochemical markers in crop evolution studies. Evolutionary Biology, v.27, p.51-95, 1993. 
GIVEN, D.R.; HARRIS, W. Techniques and methods of ethnobotany. Lincoln: Commonwealth Secretariat Publications, 1994. 148p.

GOWER J.C. Some distance properties of latent root and vector methods used in multivariate analysis. Biometrika, n.53, p.325-338, 1966.

GOMEZ-POMPA, A.; KAUS, A. The conservation of resources by traditional cultures in the tropics. World Wilderness Congress, Estes Park, 1987,18p.

GRANER, E. Contribuição para o estudo citológico da mandioca. Piracicaba: ESALQ/USP, 28p. 1935.

GRANER, E. Genética de Manihot. I. Hereditariedade da forma da folha e da coloração da película externa das raizes em Manihot utilissimum Pohl. Bragantia, n.2, p. 13-22, 1942.

GULICK, P.; C. HERSHEY; ALCAZAR, J.E. Genetic resources of cassava and wild relatives. International Board for Plant Genetic Resources (IBPGR). Secretariat Rome. 1983. 56 p.

HAMES, R. Monoculture, polyculture, and polyvariety in tropical forest swidden cultivation. Human Ecology, v.11, n.1, 1983. 
HARBORNE, J.B. Chemical data in ptractical taxonomy. In: HEYWOOD, V.H.; MOORE, D.M. (Ed) Current concepts in plant taxonomy. London: Academic Press, 1984. cap. 13, p.237-261.

HARLAN, J.R. Crops and Man. 2.ed. American Society of Agronomy, Crop Science Society of America: Madison, 1992. p.295

HERSHEY, C.; AMAYA, A. Genetica, citogenetica, estrutura floral y tecnica de bibridacion de la yuca. In: DOMINGUEZ, C.E. Yuca: investigation, produccion y utilizacion. Cali: Ciat, 1984. p.113-125.

HOEHNE, F.C. Botânica e agricultura no Brasil no século XVI. São Paulo: Nacional, 1937. 410p. (Brasiliana, 71).

HUSSAIN, A.; BUSHUK, W.; RAMIREZ, H.; ROCA, W. Identification of cassava (Manihot esculenta Crantz) cultivars by electrophoretic patterns of esterase isozymes. Seed Science and Technology, n.15, p.19-22, 1987.

KAWANO, K.; AMAYA, P.; RIOS, M. Factors affecting efficienty of hybridization and selection in cassava. Crop Science, n.17, p.373-376, 1978.

KEPHART, M. Starch gel eletroctrophoresis of plant isozymes: a comparative analysis of techniques. American Journal of Botany, $p$. 693-712, 1990. 
KERR, W.E. Agricultura e seleção genéticas de plantas. In: RIBEIRO, D. (Ed.). Suma Etnológica Brasileira. 2.ed. Petrópolis: Vozes, 1987. v. 1, cap. 10, p. 159-171.

KLEINMAN, P.J.A.; PIMENTEL, D.; BRYANT, R.B. The ecological sustainability of slash-and-burn agriculture. Agriculture, Ecosystems and Environment, v.52, n.2-3, p.235-249, 1995.

JAIN, S.K.; SINGH, R.S. Population biology of Avena. VII. Allozyme variation in relation to the genome analysis. Botanical Gazette, n.3, v.40, 1979.

JAMES, F.C.; MCCULLOCH, C.E. Multivariate analysis in ecology and systematics: panacea or Pandora's box? Annual Review of Ecology and Systematics, v.21, p.129-166, 1990.

JOLLIFE, I.T. Discarding variables in a principal component analysis; I. Artificial data. Applied Statistics, n.21, p. 160-173, 1972.

LEFÈVRE, F.; CHARRIER, A. Heredity of seventeen loci in cassava (Manihot esculenta Crantz). Euphytica, n.3, v.66, p.171-178, 1993.

MANLY, B.F.J. Randomization and Monte Carlo methods in biology. London: Chapman \& Hall, 1991. 281p.

MANLY, B.F.J. Multivariate statistical methods: a primer. 2.ed. London: Chapman \& Hall, 1995. 215p. 
MANTEL, N. The detection of disease clustering and a generalized regression approach. Cancer Research, n.27, p.209-220, 1967.

MARCGRAVE, J. História natural do Brasil. São Paulo: Museu Paulista, 1942.

MARDIA, K.V.; KENT, J.T.; BIBBY, J.M. Multivariate analysis. London: Academic Press, 1979. 521 p.

MARTINS, P.S.; JAIN, S.K. Interpopulation variation in rose clover. Journal of Heredity, v.71, p.29-32, 1980.

MARTINS, P.S. Biodiversity and agriculture: pattrens of domestication of Brazilian native plant species. Anais da Academia Brasileira de Ciências, v.66, p.219-226, 1994.

MISRA, J.; PANLEY, H.N.; TRIPATHI, R.S.; SAHOO, U.K. Weed population dynamics under 'jhum' (slash and burn agriculture) and terrace cultivation in northest India. Agriculture, Ecosystems and Environment, v.41, p.285-295, 1992.

MORRISON, D.F. Multivariate statistical methods. 2.ed. Tokio: MCGraw Hill, 1981. 415p.

NASSAR, N.M.A. Interespecific hybridization between cassava and some Manihot especies. Egyptian Journal of Genetics and Plant Breeding, n.38, p.135-137, 1978. 
NYE, M. The Mis-measure of Manioc (Manihot esculenta, Euphorbiaceae). Economic Botany, v.45, n.1, p. 47-57, 1991.

OLDFIELD, M., ALCORN, J. Conservation at tradicional agroecosystems. BioScience, v.37, n.3, p.199-208, 1987.

PADOCH, C.; JONG, W. The house gardens of Santa Rosa: diversity and variability in an amazonian agricultural system. Economic Botany, v.45, n.2, p.166-175, 1991.

PERONI, N.; MARTINS, P.S. Biodiversidade e dinâmica evolutiva de espécies cultivadas em roças de agricultura tradicional em áreas de Mata Atlântica. In: CONGRESSO NACIONAL DE BOTÂNICA, 46., Ribeirão Preto, 1995. Resumos. FFCLRP/Universidade de São Paulo: Sociedade Botânica do Brasil, 1995. p.204.

PIELOU, E.C. The interpretation of ecological data: a primer on classification and ordination. New York: John Wiley \& Sons, 1984. 263p.

PISO, G. História natural do Brasil ilustrada. São Paulo: Companhia editora Nacional, 1948. 434p.

POSEY, D.A. Manejo da floresta secundária, capoeiras, campos e cerrados (Kayapó). In: RIBEIRO, D. (Ed.). Suma Ełnológica Brasileira. 2.ed. Petrópolis: Vozes, 1987. v. 1, cap. 11, p. 173-185. 
QUEIROZ, R.S. Caipiras negros no Vale do Ribeira: um estudo de antropologia econômica. São Paulo: FLCH/USP, 1983. 167p.

QUIROS, C.F.; BRUSH, S.B.:DOUCHES,D.S.; ZIMMERER, K.S., HUESTIS, G. Biochemical and folk assessment of variability of andean cultivated potatoes. Economic Botany, v. 44, n.2, p. 254-266, 1990.

RAMIREZ, H.; HUSSAIN, A.; ROCA, W.; BUSHUK, W. IsOZYme electrophoregrams of sixteen enzyne in five tissues of Cassava (Manihot esculenta Crantz) varieties. Euphytica, v. 36, n.1, p.36-48, 1987.

RAPPAPORT, R.A. The flow of energy in an agricultural society. Scientific American, p.116-132, 1971.

RIBEIRO, B. Os índios das águas pretas: modo de produçāo e equipamento produtivo. São Paulo: Companhia das Letras, Editora da Universidade de São Paulo, 1995. 270p.

ROHLF, J. NTSYS-pc: numerical taxonomy and multivariate analysis system, version 1.70 (software). New York: Stony Brook, 1992.

ROGERS, D.J.; APPAN, S.G. Manihot and Manihotoides (Euphorbiaceae). A computer-assisted study. Flora Neotropica, Monograph n.13. New York: Hafner Press, 1973. 272p. 
ROMÃO, R.L. Dinâmica evolutiva e variabilidade de populaçōes de melancia (Citrullus lunatus)(Thumb.) Matsum \& Nakai, em três regiōes do nordeste brasileiro. Piracicaba, 1995. 63p. Dissertação (Mestrado) - Escola Superior de Agricultura "Luiz de Queiroz", Universidade de São Paulo.

SALICK, J. Crop domestication and the evolutionary ecology of cocona (Solanum sessiflorum Dunal). Evolutionary Biology, v.26, p.247-285, 1992.

SALICK, J. Toward an integration of evolutionary ecology and economic botany: personal perspectives on plant/people interactions. Annals Missouri Botanical Garden, v.82, n.1, p. 25-33, 1995.

SALICK, J.; CELLINESE, N.; KNAPP, S. Indigenous diversity of cassava: generation, maintenance, use and loss among the Amuesha, peruvian upper Amazon. Economic Botany, v. 51, p.7-17, 1997.

STADEN, H. Duas viagens pelo Brasil. São Paulo: Sociedade Hans Staden, 1942.

SAUER, J. Agricultural origins and dispersals. New York: American Geography Society. 1952.

SCHMIDT, C.B. Lavoura caiçara. Documentário da vida rural No 14. Rio de Janeiro, 1958. 79p. 
SCHULTES, R.E.; REIS, S. von. (Ed.) Ethnobotany: evolution of a discipline. Portland: Dioscorides Press, 1995. 414p.

SILVA JARDIM, J.R. Hibridação interespecífica no gênero Manihot Adams. Viçosa, 1984. 74p. Dissertação (M.S.) - Universidade Federal de Viçosa.

SCANDALIOS, J.G. Genetic control of multiple molecular forms of enzymes in plants: a review. Biochemical Genetics, n.3, p.37-39, 1969.

SNAYDON, R.W. Infraspecific variation and its taxonomic implications. In: HEYWOOD, V.H.; MOORE, D.M. (Ed) Current concepts in plant taxonomy. London: Academic Press, 1984. cap. 11, p.203-218.

SNEATH, P.H.A.; SOKAL, R.R. Numerical taxonomy. San Francisco: W.H. Freeman, 1973. 573p.

SOKAL, R.; MICHENER, C.D. A statistical method for evaluating systematic relationships. University of Kansas Science Bulletin, n.38, p.1409-1438, 1958.

SOLERI, D.; SMITH, S.E. Morphological and phenological comparisons of two hopi maize varieties conserved in situ and ex situ. Economic Botany, v.49, n.1, 1995. 
SOLTIS, D.E.; HAUFLER, C.H.; DARROW, D.C.; GASTONY, G.J. Starch gel eletrophoresis of ferns: a compilation of griding buffers, gel and electrode buffers, and staining schedules. American Fern Journal, n.73, p.9-27, 1983.

SPIX, J.B. von; MARTIUS, C.F.P. Viagem pelo Brasil (1817-1820). 4.ed. São Paulo: Itatiaia, 1981. 3v.

StatSoft, Inc. STATISTICA for Windows (Computer program manual). Tulsa, 1996.

SYSTAT, Inc. SYSTAT for Windows. Version 5.01 (software). Evanston, 1992.

WESTPHAL, E. L'agriculture autochtone au Cameroun. Miscellaneous papers, n.20, p.175, 1981.

ZEVEN, A.C. et al. Phenotypic variation within a Hungarian landrace of runner bean (Phaseolus coccineus L.). Euphytica, v.68, n.1-2, p.155$166,1993$. 
APÊNDICES. 
APÊNDICE 1. Roteiro de entrevista:

$\begin{array}{ll}\text { Nome: } & \text { Idade } \\ \text { Escolaridade: } & \text { Local: }\end{array}$

1- Tamanho da família: quantos participam da atividade agrícola?

2- Atividade econômica, referente a cultura da mandica:

( ) subsistência ( ) comercial ( ) intermediária

3- Agricultura de coivara:

3.1. Limpeza do terreno, preparo do solo:
atividade: ( )masc.
( ) fem.
( )ambos

3.2 Plantio:

a) época:

b) variedades cultivadas (Brava ou mansa):

c) Origem de cada uma:

d) Plantio em: ( )cova ( )leira ( )linha

e) tamanho da maniva f) posição da maniva

g) área de plantio: $\quad$ h) topografia

i) atividade: ( )masc. ( )fem. ( )ambos

j) consórcio com outras culturas. Quais culturas e que variedades?

4) Tratos culturais:

- Faz adubação, capina e poda? Épocas?

5) Colheita:

- Época:

- Quantos quilos estima colher no ciclo?

- Obs.:

6) Mandioca nascida de semente:

Observou novos pés? Como identificar?

7) Plantou novos tipos de mandioca nos últimos dois anos? Trocou com alguém?

8) Aumentou a área de plantio de alguma variedade? Qual a razão? 
APÊNDICE 2. Resultados da análise de solo das três roças de Ariri 1.

Resultados das análises químicas

\begin{tabular}{|c|c|c|c|c|c|c|c|c|c|c|c|c|c|}
\hline \multirow{2}{*}{$\begin{array}{c}\text { Amostra } \\
\text { Identificacao }\end{array}$} & \multirow{2}{*}{$\begin{array}{c}\mathrm{pH} \\
\mathrm{CaCl} 2\end{array}$} & \multirow{2}{*}{$\begin{array}{c}\text { M.O. } \\
\%\end{array}$} & \multirow{2}{*}{\multicolumn{2}{|c|}{$\mathrm{ug} / \mathrm{cm} 3$}} & K & $\mathrm{Ca}$ & $\mathrm{Mg}$ & Al & $\mathrm{H}+\mathrm{Al}$ & SB & $T$ & $V$ & $\mathrm{~m}$ \\
\hline & & & & & & & \multicolumn{5}{|c|}{$\mathrm{meg} / 100 \mathrm{~cm} 3$} & \multicolumn{2}{|c|}{$\%$} \\
\hline Roça 1 & 4,0 & 2,6 & 13 & 11,23 & 0,06 & 1,2 & 0,6 & 0,2 & 3,4 & 1,9 & 5,3 & 36 & 10 \\
\hline$R \propto$ & 3,1 & 1,8 & 8 & 9 & 0,04 & 0,6 & 0,3 & 0,4 & 3,8 & 0,9 & 4,7 & 19 & 31 \\
\hline Roca 3 & 3,3 & 2,8 & 9 & 11,23 & 0,03 & 0,6 & 0,4 & 0,5 & 5,8 & 1,0 & 6,8 & 15 & 33 \\
\hline
\end{tabular}

Resultados das análises de micronutrientes

\begin{tabular}{|c|c|c|c|c|c|c|}
\hline \multirow{2}{*}{$\begin{array}{c}\text { Amostra } \\
\text { Identificaç } \\
\text { ão }\end{array}$} & $\bar{B}$ & $\mathrm{Cu}$ & $\mathrm{Fe}$ & $M n$ & $\mathrm{Zn}$ & \multirow{2}{*}{$\begin{array}{l}\overline{\mathrm{Na}} \\
(\mathrm{ppm})\end{array}$} \\
\hline & & & & (ppm) & & \\
\hline Roca 1 & 1,33 & 0,58 & 24 & 16,08 & 1,2 & 21 \\
\hline Roca 2 & 0,61 & 0,52 & 41 & 2,76 & 1,5 & 12 \\
\hline Roça 3 & 0,65 & 0,10 & 55 & 3,28 & 2,0 & 18 \\
\hline
\end{tabular}

Resultados das análises granulométricas

\begin{tabular}{|c|c|c|c|c|c|c|c|c|c|c|c|}
\hline \multirow{2}{*}{$\begin{array}{l}\text { Amostra } \\
\text { Identificação }\end{array}$} & \multirow{2}{*}{ MG. } & \multirow[b]{2}{*}{$\mathrm{G}$. } & \multicolumn{4}{|c|}{ AREIA (\%) } & \multirow{2}{*}{$\begin{array}{l}\text { SILTE } \\
(\%)\end{array}$} & \multicolumn{2}{|c|}{$\begin{array}{c}\text { ARGILA } \\
(\%)\end{array}$} & \multicolumn{2}{|c|}{ Flo $\mathrm{CI} \mathrm{D}_{\mathrm{P}} \mathrm{DS}$} \\
\hline & & & M. & $F$. & MF. & TOT. & & TOT. & $\overline{A G U A}$ & & $\begin{array}{c}\mathrm{G} / \mathrm{CM} \\
3 \\
\end{array}$ \\
\hline Roça 1 & - & - & - & 81 & 5 & 86 & 8 & 6 & 1 & 83 & ar. - \\
\hline Roça 2 & - & - & 2 & 84 & 4 & 90 & 6 & 4 & 1 & 75 & ar. - \\
\hline Roça 3 & - & _ & - & 85 & 3 & 88 & 7 & 5 & 1 & 80 & ar. - - \\
\hline
\end{tabular}


APÉNDICE 3. Matriz de distância euclideana média, para as vinte amostras de mandioca de Ariri 1 roça1.

\begin{tabular}{|c|c|c|c|c|c|c|c|c|c|c|c|c|c|c|c|c|c|c|c|c|}
\hline & A01 & $\overline{\mathrm{A02}}$ & $\mathrm{A03}$ & $A 04$ & A05 & A07 & $\overline{A 09}$ & $\overline{\mathrm{A} 10}$ & $\overline{A 12}$ & $\overline{A 13}$ & A14 & $\overline{A 16}$ & A16 & A18 & $\overline{A 22}$ & A24 & $\overline{\mathbf{A} 27}$ & A28 & A29 & $\overline{A 30}$ \\
\hline $\mathbf{A 0 1}$ & 0 & & & & & & & & & & & & & & & & & & & \\
\hline A02 & 0,02 & 0 & & & & & & & & & & & & & & & & & & \\
\hline A.03 & 0,44 & 0,84 & 0 & & & & & & & & & & & & & & & & & \\
\hline AO4 & 1,54 & 1,3 & 1,67 & 0 & & & & & & & & & & & & & & & & \\
\hline A05 & 1,43 & 1,46 & 1,24 & 1,45 & 0 & & & & & & & & & & & & & & & \\
\hline$A 07$ & 1,12 & 1,29 & 1,26 & 1,12 & 1,53 & 0 & & & & & & & & & & & & & & \\
\hline A08 & 0,95 & 1,34 & 0,97 & 2,02 & 1,72 & 1,49 & 0 & & & & & & & & & & & & & \\
\hline A10 & 0,38 & 0,99 & 0,5 & 1,78 & 1,52 & 1,17 & 0,85 & 0 & & & & & & & & & & & & \\
\hline A12 & 0,55 & 0,34 & 0,82 & 1,39 & 1,52 & 1,27 & 1,31 & 0,91 & 0 & & & & & & & & & & & \\
\hline A13 & 0,46 & 0,18 & $0, \infty$ & 1,34 & 1,41 & 1,22 & 1,21 & 0,83 & 0,36 & 0 & & & & & & & & & & \\
\hline A14 & 1,3 & 1,37 & 1.45 & 0,76 & 1,39 & 0.7 & 1.7 & 1,4 & 1,33 & 1,33 & 0 & & & & & & & & & \\
\hline A15 & 1,25 & 1,32 & 1,15 & 1,32 & 0,36 & 1,36 & 1,61 & 1,35 & 1,32 & 1,26 & 1,17 & 0 & & & & & & & & \\
\hline A16 & 0,19 & 0,66 & 0,4 & 1,55 & 1,4 & 1,13 & 0,93 & 0,39 & 0,68 & 0,49 & 1,33 & 1,25 & 0 & & & & & & & \\
\hline A18 & 1,27 & 1,46 & 1,32 & 1,6 & 1,62 & $1, \infty$ & 1,57 & 1,3 & 1,45 & 1,39 & 1,32 & 1,5 & 1,27 & 0 & & & & & & \\
\hline $\mathbf{A} 22$ & 1,34 & 1,14 & 1,4 & 0,99 & 0,93 & 1,45 & 1,83 & 1,58 & 1,23 & 1,15 & 1,2 & 0,77 & 1,34 & $1, \infty$ & 0 & & & & & \\
\hline A24 & 0,83 & $1, \infty 2$ & 0,94 & 1,78 & 1,67 & 1,45 & 0,51 & 0,92 & 0,98 & 0,94 & 1,59 & 1,52 & 0,85 & 1,57 & 1,59 & 0 & & & & \\
\hline A.27 & 1,28 & 1,28 & 1,52 & 1,53 & 1,69 & 1,42 & 1,68 & 1,44 & 1,15 & 1,3 & 1,27 & 1,47 & 1,39 & $1, \boldsymbol{\oplus}$ & 1,56 & 1,51 & 0 & & & \\
\hline A28 & 1,33 & 1,13 & 1,45 & 0,91 & 1,47 & 1,04 & 1,83 & 1,57 & 1,13 & 1,17 & 0,98 & 1,34 & 1,39 & 1,24 & 1,25 & 1,58 & 1,21 & 0 & & \\
\hline$A 29$ & 1,14 & 0,85 & 1,27 & 1,56 & 1,72 & 1,66 & 1,2 & 1,42 & 0,99 & 0,89 & 1,71 & 1,63 & 1,15 & 1,79 & 1,42 & $0, \pi 7$ & 1,61 & 1,46 & 0 & 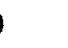 \\
\hline $\mathbf{A 3 0}$ & 1,26 & 1,24 & 1,2 & 1,03 & 1,25 & 0,84 & $1, \infty$ & 1,39 & 1,35 & 1,19 & 1,07 & 1,21 & 1,21 & 1,3 & 1,21 & $1, 历$ & 1,83 & 1,1 & 1,54 & \\
\hline
\end{tabular}

APÊNDICE 4. Matriz de distância euclideana média para doze amostras de mandioca de Ariri 1 roça 2.

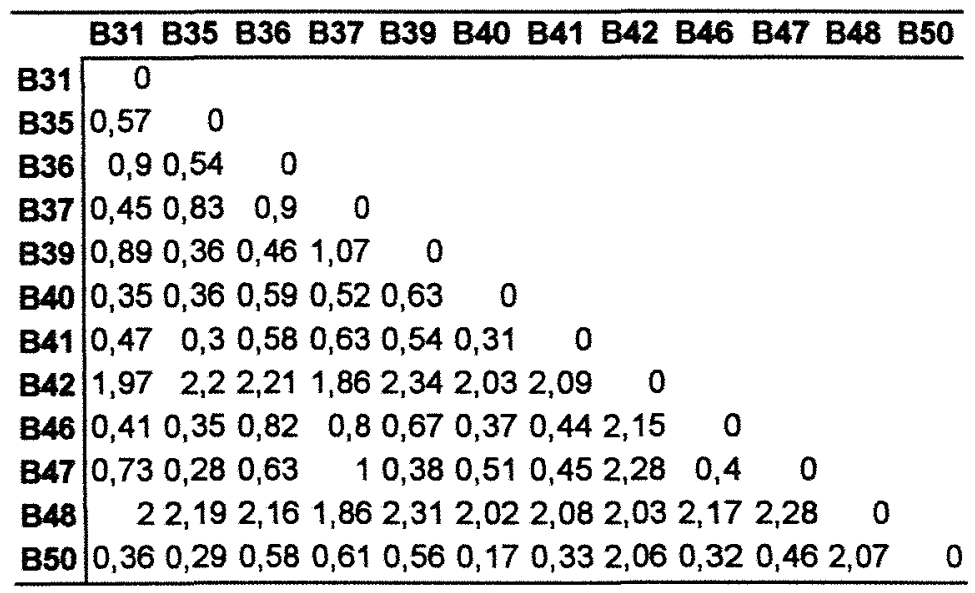


APÊNDICE 5. Matriz de distância euclideana média para dezessete amostras de mandioca de Ariri 1 roça 3.

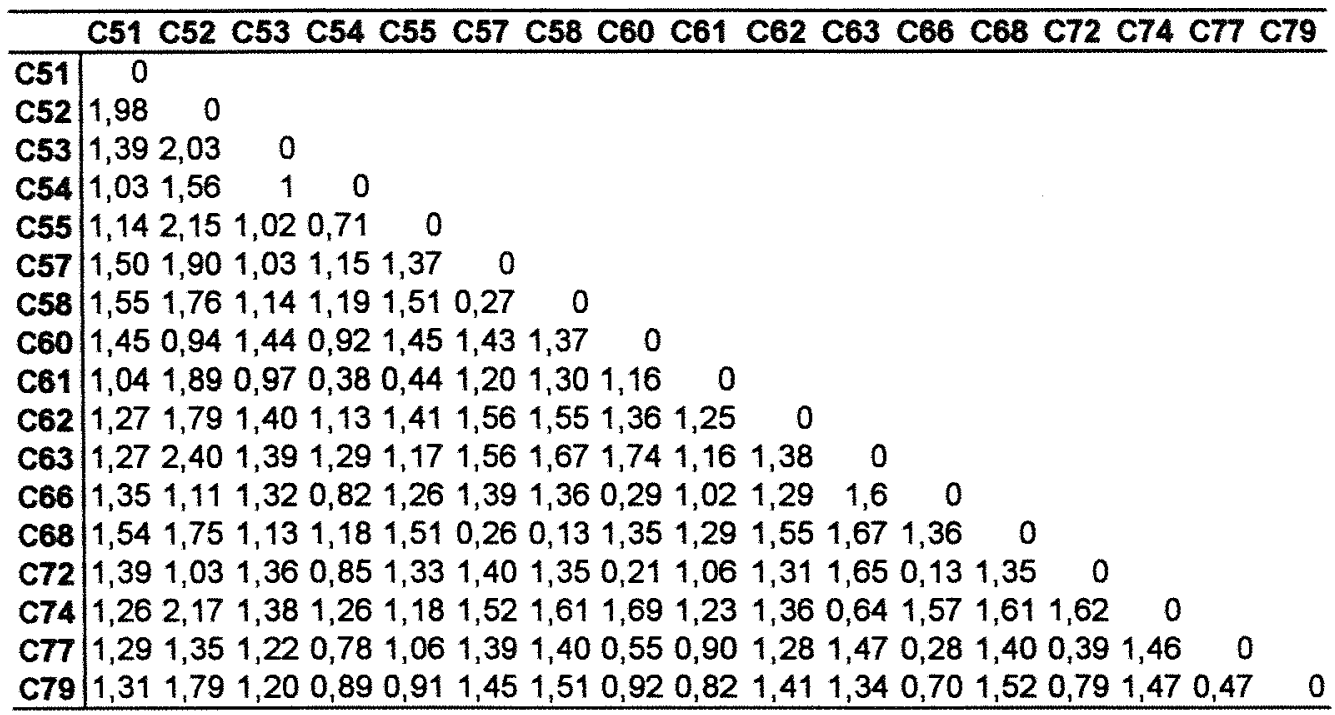


APÊNDICE 6. Matriz de distância euclideana média para trinta e duas amostras de mandioca de Ariri 2 roça 1

\begin{tabular}{|c|c|c|c|c|c|c|c|c|c|c|c|c|c|c|c|c|c|c|c|}
\hline & CG1 & MD2 & C3 & CG4 & C8 & CG8 & MD7 & C8 & AG9 & CG10 & $\overline{A G 11 ~}$ & MD12 & $C_{13}$ & C14 & C16 & CO16 & $\mathrm{C} 17$ & CG18 & CG19 \\
\hline $\cot 1$ & $\overline{0}$ & & & & & & & & & & & & & & & & & & \\
\hline MD2 & 1,31 & 0 & & & & & & & & & & & & & & & & & \\
\hline C3 & 1,65 & 1,53 & 0 & & & & & & & & & & & & & & & & \\
\hline CG4 & 1,25 & 1,19 & $1, \infty$ & 0 & & & & & & & & & & & & & & & \\
\hline CE & 1,92 & 1,82 & 1,29 & 1,7 & 0 & & & & & & & & & & & & & & \\
\hline CG8 & 1,28 & 1,28 & 1,27 & 1,03 & 1,62 & 0 & & & & & & & & & & & & & \\
\hline MD7 & 1,76 & 0,94 & 1,59 & 1,43 & 1,77 & 1,17 & 0 & & & & & & & & & & & & \\
\hline$C 8$ & 1,71 & 1,58 & 0,93 & 1,48 & 1,07 & 1,3 & 1,54 & 0 & & & & & & & & & & & \\
\hline AG9 & 1,89 & 1,78 & 2,12 & 1,46 & 1,93 & 1,48 & 1,74 & 1,77 & 0 & & & & & & & & & & \\
\hline CQ10 & 1,12 & 1,22 & 1,22 & 0,89 & 1,52 & 0,73 & 1,33 & 1,33 & 1,57 & 0 & & & & & & & & & \\
\hline AG11 & 1,69 & 1,88 & 2,23 & 1,48 & 2,05 & 1,54 & 1,86 & 1,92 & 0,73 & 1,5 & 0 & & & & & & & & \\
\hline AD12 & 1,49 & 0,86 & 1,49 & 1,35 & 1,62 & 1,32 & 0,79 & 1,47 & 1,78 & 1,09 & 1,76 & 0 & & & & & & & \\
\hline$C 13$ & 1,96 & 1,83 & 1,28 & 1,75 & 0,39 & 1,59 & 1,8 & 0,95 & 1,91 & 1,57 & 2,07 & 1,7 & 0 & & & & & & \\
\hline 144 & 1,58 & 1,54 & 0,93 & 1,39 & 0,95 & 1,3 & 1,5 & 0,54 & 1,72 & 1.16 & 1,77 & 1,28 & 1,02 & 0 & & & & & \\
\hline 16 & 1,57 & 1,52 & 0,98 & 1,34 & 1,06 & 1,31 & 1,44 & 0,67 & 1,84 & 1,2 & 1,89 & 1,31 & .15 & 0,41 & 0 & & & & \\
\hline G16 & 1,14 & 1,00 & 1,24 & 0,74 & 1,56 & 0,75 & 1,39 & 1,28 & 1,48 & 0,65 & 1,54 & 1,28 & 1,55 & 1,25 & 1,29 & 0 & & & \\
\hline 17 & 2,31 & 1,99 & 1,39 & 2,01 & 1,38 & 1,8 & 1,96 & 1,03 & 1,92 & 1,87 & 2,3 & 1,97 & 1,22 & 1,28 & 1,49 & 1,73 & 0 & & \\
\hline G18 & 1,15 & 1,17 & 1,19 & 0,8 & 1,54 & 0,64 & 1,26 & 1,27 & 1,65 & 0,34 & 1,62 & 1.13 & 1,57 & 1,17 & 1,13 & 0,59 & 1,89 & 0 & \\
\hline G19 & 1,16 & 1,33 & 1,44 & 0,95 & 1,73 & 1,01 & 1,4 & 1,58 & 1,85 & 0,62 & 1,7 & 1,17 & 1,85 & 1,33 & 1,22 & 0,99 & 2,28 & 0,56 & \\
\hline 20 & 1,69 & 1,54 & 0,92 & 1,42 & 0,91 & 1,35 & 1,47 & 0,54 & 1,75 & 1,24 & 1,8 & 1,32 & 1 & 0,26 & 0,43 & 1,29 & 1,15 & 1,23 & 1,42 \\
\hline D2 & 1,59 & 1,2 & 1,11 & 1,27 & 1,37 & 1,1 & 1,13 & 0,92 & 1,68 & 1,12 & & & 1,31 & 1,03 & 1,06 & 1,08 & 1,38 & ,04 & 137 \\
\hline G22 & 1,00 & 1,28 & 1,56 & 0,92 & 1,83 & 1,2 & 1,52 & 1,68 & 1,83 & 0,86 & 1,6 & 1,28 & 1,95 & 1,43 & 1,36 & 0,98 & 2,4 & 0,84 & 0,54 \\
\hline G23 & 1,47 & 1,38 & 1,64 & 1,29 & 1,79 & 1,1 & 1,04 & 1, ๓3 & 1,77 & $1, \infty 9$ & & 1,07 & 1,91 & 1,41 & 1,33 & 1,34 & 2,31 &, 06 & 0,9 \\
\hline D? & 1,42 & 1,08 & 1,06 & 1,1 & 1,44 & $1, \infty 3$ & 1,15 & 1,13 & 1,77 & 0,92 & & & 1,48 & 1,06 & 1,02 & 1,01 & 1 , & 83 & 1,02 \\
\hline CG25 & 1,27 & 1,05 & 1,34 & 0,99 & 1,65 & 1 & 1,13 & 1,44 & 1,79 & 0,73 & 1. & 0,95 & 1,73 & 1,27 & 1,2 & 0,98 & 2,08 & 66 & 0,63 \\
\hline AD28 & 1,31 & 1,26 & 1,63 & 1,17 & 1,79 & 1,43 & 1,34 & 1,64 & 1,85 & 1,15 & 1. & 1,06 & 1,92 & 1,39 & 1, & 1,26 & 2 & 14 & 91 \\
\hline C27 & 1,58 & 1,53 & 0,91 & 1,4 & 0,92 & 1,28 & 1,5 & & 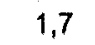 & & & 1,3 & & & & & & & \\
\hline MD28 & 1,54 & 1,28 & 1,42 & 1,28 & 1,54 & 0,87 & 0,95 & 1,36 & 1,38 & 0,96 & 1, & 1,02 & 1,58 & 1,23 & 1,34 & 1,09 & 1,73 & 1,03 & 1,23 \\
\hline 32 & 1,24 & 1,18 & 1,06 & 0,94 & 1,46 & 0,91 & 1,47 & 1,06 & 1,59 & 0,91 & 1,6 & & 1,41 & 1,13 & 1,17 & 0,56 & 1,57 & 0,82 & 1,21 \\
\hline 43 & 1,89 & 2,09 & 1,57 & 1,82 & 1,76 & 1,62 & 2 & 1,66 & 1,94 & 1,5 & 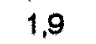 & & 1,76 & 1,57 & 1,67 & 1,53 & 1,9 & 1,57 & \\
\hline 31 & 1,57 & 1,55 & 0,92 & 1,4 & 0,96 & 1,28 & 1.51 & 0,5 & 1,69 & 1,14 & 1,74 & 1,29 & 0,99 & 0,13 & 0,46 & 1,24 & 1,24 & 1,17 & 1,35 \\
\hline 32 & 1,59 & 15 & 0,92 & 1,35 & 1,01 & 1,27 & 1.44 & 0,47 & 1.8 & 1.21 & 189 & 1,33 & 1.04 & 0,35 & 0.22 & 1,25 & 32 & 1,14 & 132 \\
\hline
\end{tabular}


cont.

C20 MD2 CG2 CG2 MD2 CG2 MD2 C27 MD2 CG2 AM3 C31 C32

\begin{tabular}{|c|c|c|c|c|c|c|c|c|c|c|c|c|c|}
\hline & & 1 & 2 & 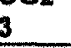 & 4 & 6 & 6 & & 8 & 9 & 0 & & \\
\hline $\mathrm{C}_{20}$ & $\overline{0}$ & & & & & & & & & & & & \\
\hline MD21 & 1 & 0 & & & & & & & & & & & \\
\hline CG22 & 1,53 & 1,5 & 0 & & & & & & & & & & \\
\hline CG23 & 1,48 & 1,27 & 1 & 0 & & & & & & & & & \\
\hline MD24 & 1,06 & 0,6 & 1,15 & 1,06 & 0 & & & & & & & & \\
\hline CG26 & 1,32 & 1.01 & 0,8 & 0,75 & 0,62 & 0 & & & & & & & \\
\hline MD26 & 1,46 & 1,32 & 0,73 & 0,79 & 1,08 & 0,79 & 0 & & & & & & \\
\hline $\mathrm{C} 27$ & 0,24 & 1 & 1,49 & 1,46 & 1,07 & 1,31 & 1,45 & 0 & & & & & \\
\hline MD28 & 1,26 & 0,95 & 1,34 & 0,82 & 0,99 & 0,94 & 1,2 & 1,23 & 0 & & & & \\
\hline CG29 & 1,16 & 0,88 & 1,19 & 1,48 & 0,87 & 1,14 & 1,38 & 1,1 & 1,24 & 0 & & & \\
\hline AM30 & 1,64 & 1,78 & 2,01 & 2,13 & 1,8 & 1,92 & 2,17 & 1,53 & 1,84 & 1,52 & 0 & & \\
\hline C31 & 0,34 & 1,02 & 1,46 & 1,44 & 1,08 & 1,29 & 1,42 & 0,14 & 1,22 & 1,1 & 1,53 & 0 & \\
\hline C32 & 0,33 & 0,97 & 1,44 & 1,41 & 1,01 & 1,25 & 1,39 & 0,34 & 1,31 & $1, \infty$ & 1,63 & 0,39 & 0 \\
\hline
\end{tabular}

Legenda: C - Cascudinha; CG - Cascuda Grande; AM - Aipim Manteiga; AG - Aipim Guaçu. 
L APÊNDICE 7. Matriz de distância euclideana média para vinte amostras de mandioca de Ariri 2 roça 3

\begin{tabular}{|c|c|c|c|c|c|c|c|c|c|c|c|c|c|c|c|c|c|c|c|c|}
\hline & MD48 & $\mathrm{CA9}$ & C50 & AG61 & $\overline{C 82}$ & AG53 & $\mathrm{CE4}$ & C56 & $\overline{C E B}$ & CG57 & $\mathrm{CEB}$ & C69 & C60 & C61 & CG62 & $\mathrm{C} 63$ & C64 & CG65 & CG66 & MD67 \\
\hline MD48 & 0 & & & & & & & & & & & & & & & & & & & \\
\hline $\mathrm{C} 49$ & 1,6 & 0 & & & & & & & & & & & & & & & & & & \\
\hline C50 & 1,53 & 1,26 & 0 & & & & & & & & & & & & & & & & & \\
\hline AGE1 & 1,77 & 1,99 & 1,36 & 0 & & & & & & & & & & & & & & & & \\
\hline $\mathrm{C} 52$ & 1,46 & 1,02 & 0,42 & 1,36 & 0 & & & & & & & & & & & & & & & \\
\hline AGB3 & 1,52 & 1,99 & 1,53 & 0,79 & 1,5 & 0 & & & & & & & & & & & & & & \\
\hline C54 & 1,38 & 0,61 & 0,81 & 1,62 & 0,55 & 1,68 & 0 & & & & & & & & & & & & & \\
\hline C55 & 1,38 & 0,92 & 0,66 & 1,49 & 0,46 & 1,63 & 0,44 & 0 & & & & & & & & & & & & \\
\hline C56 & 1,46 & 0,75 & 0,74 & 1,55 & 0,49 & 1,67 & 0,47 & 0,32 & 0 & & & & & & & & & & & \\
\hline CG67 & 1,65 & 1,77 & 1,78 & 1,63 & 1,63 & 1,58 & 1,62 & 1,69 & 1,66 & 0 & & & & & & & & & & \\
\hline C58 & 1,59 & 1,26 & 0,69 & 1,43 & 0,58 & 1,59 & 0,86 & 0,68 & 0,72 & 1,76 & 0 & & & & & & & & & \\
\hline C59 & 1,47 & 0,69 & 1,21 & 1,88 & 0,99 & 1,93 & 0,51 & 0,69 & 0,71 & 1,76 & 1,17 & 0 & & & & & & & & \\
\hline $\mathrm{C60}$ & 1,44 & 0,57 & 1,19 & 1,89 & 0,95 & 1,91 & 0,42 & 0,71 & 0,74 & 1,75 & 1,18 & 0,28 & 0 & & & & & & & \\
\hline C61 & 1,65 & 0,29 & 1,31 & 2,01 & 1,07 & 2 & 0,65 & 0,98 & 0,8 & 1,75 & 1,3 & 0,63 & 0,61 & 0 & & & & & & \\
\hline CG62 & 1,53 & 1,97 & 1,41 & 1,1 & 1,4 & 1,19 & 1,62 & 1,51 & 1,56 & 1,38 & 1,25 & 1,87 & 1,87 & 1,98 & 0 & & & & & \\
\hline $\mathrm{C} 63$ & 1,4 & 0,82 & 0,88 & 1,67 & 0,73 & 1,76 & 0,43 & 0,35 & 0,47 & 1,73 & 0,9 & 0,43 & 0,53 & 0,82 & 1,66 & 0 & & & & \\
\hline C64 & 1,4 & 0,95 & 0,95 & 1,65 & 0,76 & 1,77 & 0,53 & 0,36 & 0,53 & 1,75 & 0,9 & 0,48 & 0,57 & 0,97 & 1,65 & 0,3 & 0 & & & \\
\hline CG65 & 1,47 & 1,52 & 1,65 & 1,54 & 1,49 & 1,5 & 1,42 & 1,48 & 1,4 & 1,2 & 1,41 & 1,48 & 1,51 & 1,48 & 0,99 & 1,48 & 1,5 & 0 & & \\
\hline CG68 & 1,5 & 1,89 & 1,45 & 1,14 & 1,38 & 1,18 & 1,57 & 1,51 & 1,55 & 1,27 & 1,27 & 1,82 & 1,8 & 1,89 & 0,28 & 1,66 & 1,65 & 0,88 & 0 & \\
\hline MD67 & 0,72 & 1,81 & 1,36 & 1,5 & 1,35 & 1,28 & 1,52 & 1,44 & 1,47 & 1,63 & 1,44 & 1,76 & 1,75 & 1,84 & 1,25 & 1,57 & 1,58 & 1,5 & 1,26 & 0 \\
\hline
\end{tabular}

Legenda: C - Cascudinha; CG - Cascuda Grande; AM - Aipim Manteiga; AG - Aipim Guaçu. 
APÊNDICE 8. Correlações de Spearman entre cada par de caracteres entre etnovariedades da localidade de Ariri1 roca 1

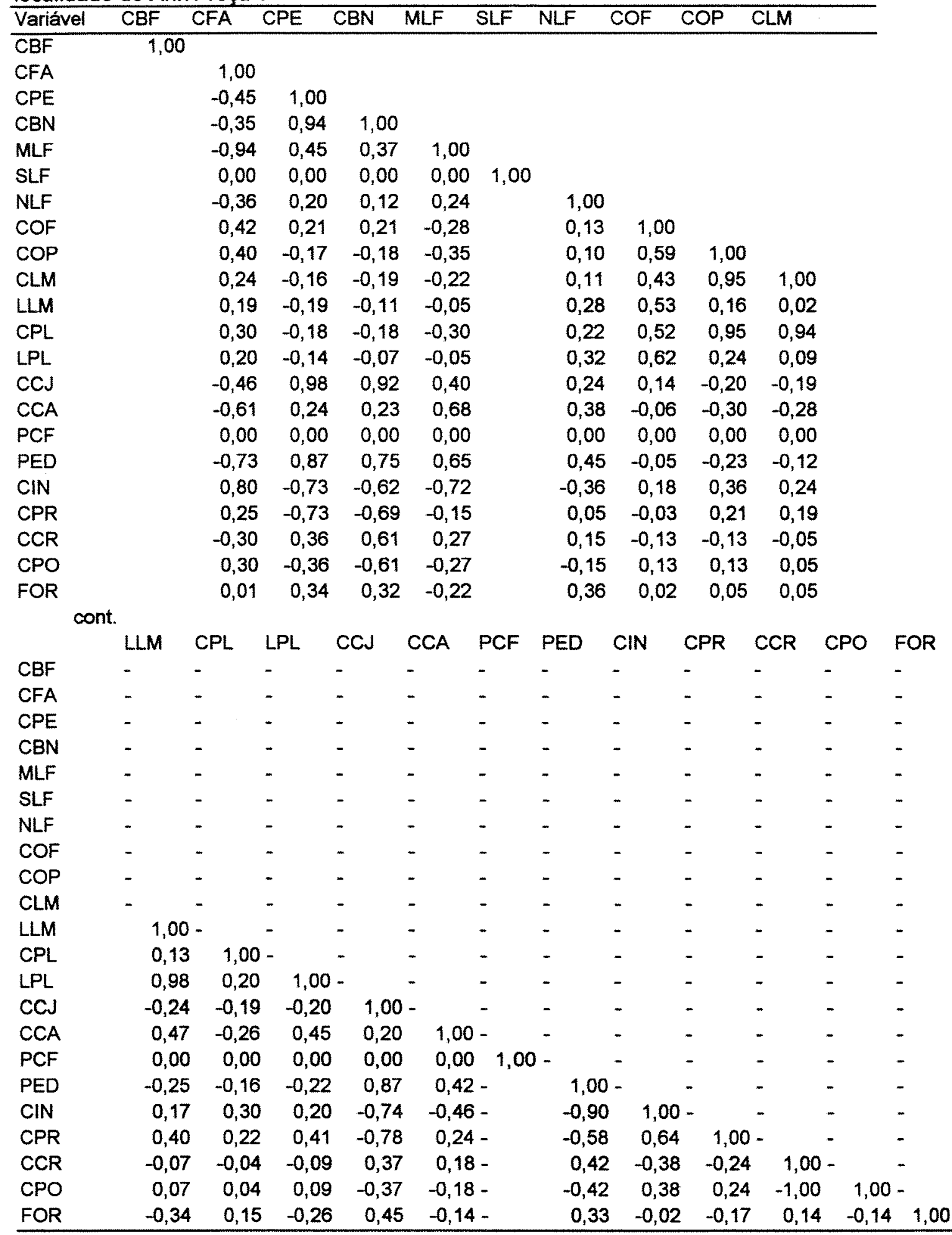


APÊNDICE 9. Correlações de Spearman entre cada par de caracteres entre etnovariedades da localidade de Ariri1 roça 2.

\begin{tabular}{|c|c|c|c|c|c|c|c|c|c|c|}
\hline Variável & CBF & CFA & CPE & $\overline{\mathrm{CBN}}$ & $\overline{M L F}$ & SLF & NLF & $\mathrm{COF}$ & $\mathrm{COP}$ & CLM \\
\hline$\overline{\mathrm{CBF}}$ & 1,00 & & & & & & & & & \\
\hline CFA & $-0,67$ & 1,00 & & & & & & & & \\
\hline $\mathrm{CPE}$ & 0,67 & $-1,00$ & 1,00 & & & & & & & \\
\hline CBN & 0,67 & $-1,00$ & 1,00 & 1,00 & & & & & & \\
\hline MLF & 0,67 & $-1,00$ & 1,00 & 1,00 & 1,00 & & & & & \\
\hline SLF & 0,00 & 0,00 & 0,00 & 0,00 & 0,00 & 1,00 & & & & \\
\hline NLF & $-0,05$ & $-0,22$ & 0,22 & 0,22 & $0,22-$ & & 1,00 & & & \\
\hline COF & $-0,48$ & 0,65 & $-0,65$ & $-0,65$ & $-0,65-$ & & 0,05 & 1,00 & & \\
\hline COP & $-0,39$ & 0,65 & $-0,65$ & $-0,65$ & $-0,65$ & & 0,05 & 0,90 & 1,00 & \\
\hline CLM & $-0,39$ & 0,65 & $-0,65$ & $-0,65$ & $-0,65-$ & & $-0,01$ & 0,91 & 0,99 & 1,00 \\
\hline LLM & $-0,48$ & 0,65 & $-0,65$ & $-0,65$ & $-0,65-$ & & 0,36 & 0,71 & 0,83 & 0,78 \\
\hline CPL & $-0,39$ & 0,65 & $-0,65$ & $-0,65$ & $-0,65-$ & & 0,07 & 0,87 & 0,99 & 0,99 \\
\hline LPL & $-0,48$ & 0,65 & $-0,65$ & $-0,65$ & $-0,65$ & & 0,20 & 0,74 & 0,83 & 0,80 \\
\hline CCJ & 0,74 & $-1,00$ & 1,00 & 1,00 & $1,00-$ & & 0,19 & $-0,65$ & $-0,64$ & $-0,64$ \\
\hline$C C A$ & $-0,09$ & $-0,67$ & 0,67 & 0,67 & 0,67 & & 0,34 & $-0,39$ & $-0,48$ & $-0,48$ \\
\hline PCF & 0,00 & 0,00 & 0,00 & 0,00 & $0,00 \ldots$ & & 0,00 & 0,00 & 0,00 & 0,00 \\
\hline PED & $-0,09$ & $-0,67$ & 0,67 & 0,67 & 0,67 & & 0,34 & $-0,39$ & $-0,48$ & $-0,48$ \\
\hline CIN & $-1,00$ & 0,67 & $-0,67$ & $-0,67$ & $-0,67-$ & & 0,05 & 0,48 & 0,39 & 0,39 \\
\hline CPE & $-1,00$ & 0,67 & $-0,67$ & $-0,67$ & $-0,67$ & & 0,05 & 0,48 & 0,39 & 0,39 \\
\hline CCR & $-0,74$ & 0,00 & 0,00 & 0,00 & 0,00 & & 0,26 & 0,06 & $-0,06$ & $-0,06$ \\
\hline CPR & 0,00 & 0,00 & 0,00 & 0,00 & 0,00 & & 0,00 & 0,00 & 0,00 & 0,00 \\
\hline FOR & $-0,09$ & $-0,67$ & 0,67 & 0,67 & $0,67-$ & & 0,34 & $-0,39$ & $-0,48$ & $-0,48$ \\
\hline
\end{tabular}

cont.

Variável LLM CPL LPL CCJ CCA PCF PED CIN CPE CCR CPR FOR CBF

CFA

CPE

CBN

MLF

SLF

NLF

COF

COP

CLM

LLM

CPL

1,00

LPL $\quad 0,91 \quad 0,83 \quad 1,00$

$\begin{array}{lllll}\text { CCJ } & -0,65 & -0,64 & -0,65 & 1,00\end{array}$

$\begin{array}{llllll}\text { CCA } & -0,39 & -0,48 & -0,39 & 0,60 & 1,00\end{array}$

$\begin{array}{lllllll}\text { PCF } & 0,00 & 0,00 & 0,00 & 0,00 & 0,00 & 1,00\end{array}$

$\begin{array}{lllllll}\text { PED } & -0,39 & -0,48 & -0,39 & 0,60 & 1,00- & 1,00\end{array}$

$\begin{array}{lllllll}\text { CIN } & 0,48 & 0,39 & 0,48 & -0,74 & 0,09- & 0,09\end{array}$

$\begin{array}{lllllllll}\text { CPE } & 0,48 & 0,39 & 0,48 & -0,74 & 0,09- & 0,09 & 1,00 & 1,00\end{array}$

$\begin{array}{llllllllll}\text { CCR } & 0,06 & -0,06 & 0,06 & -0,09 & 0,74- & 0,74 & 0,74 & 0,74 & 1,00\end{array}$

$\begin{array}{lllllllllll}\text { CPR } & 0,00 & 0,00 & 0,00 & 0,00 & 0,00- & 0,00 & 0,00 & 0,00 & 0,00 & 1,00\end{array}$

\begin{tabular}{lllllllllll} 
FOR & $-0,39$ & $-0,48$ & $-0,39$ & 0,60 & $1,00-$ & 1,00 & 0,09 & 0,09 & $0,74-$ & 1,00 \\
\hline
\end{tabular}


APÊNDICE 10. Correlações de Spearman entre cada par de caracteres entre etnovariedades da localidade de Ariri1 roça 3.

\begin{tabular}{|c|c|c|c|c|c|c|c|c|c|c|c|}
\hline Variável & CBF & CFA & CPE & $\mathrm{CBN}$ & MLF & SLF & NLF & COF & COP & $\overline{C L M}$ & \\
\hline$\overline{\mathrm{CBF}}$ & 1,00 & & - & - & - & - & - & - & - & - & \\
\hline CFA & $-0,34$ & $1,00-$ & & - & - & - & - & - & - & - & \\
\hline CPE & 0,12 & $-0,31$ & 1,00 & & - & - & - & - & - & - & \\
\hline $\mathrm{CBN}$ & 0,12 & $-0,31$ & 1,00 & 1,00 & - & - & - & - & - & - & \\
\hline MLF & 0,16 & 0,00 & 0,69 & 0,69 & 1,00 & - & - & - & - & - & \\
\hline SLF & - & - & - & - & - & $1,00-$ & - & - & - & - & \\
\hline NLF & 0,05 & 0,10 & $-0,03$ & $-0,03$ & 0,08 & - & 1,00 & - & - & - & \\
\hline COF & $-0,11$ & 0,83 & $-0,32$ & $-0,32$ & 0,13 & & 0,42 & $1,00-$ & - & - & \\
\hline COP & $-0,07$ & 0,69 & $-0,01$ & $-0,01$ & 0,32 & & 0,42 & 0,91 & $1,00-$ & - & \\
\hline CLM & $-0,11$ & 0,66 & 0,01 & 0,01 & 0,32 & & 0,44 & 0,89 & 1,00 & 1,00 & \\
\hline LLM & 0,13 & 0,53 & $-0,64$ & $-0,64$ & $-0,12$ & & 0,25 & 0,79 & 0,67 & 0,65 & \\
\hline CPL & $-0,04$ & 0,62 & $-0,04$ & $-0,04$ & 0,25 & & 0,44 & 0,85 & 0,96 & 0,96 & \\
\hline LPL & 0,26 & 0,40 & $-0,52$ & $-0,52$ & $-0,03$ & & 0,45 & 0,76 & 0,67 & 0,66 & \\
\hline $\mathrm{CCJ}$ & 0,08 & $-0,31$ & 0,96 & 0,96 & 0,63 & & $-0,05$ & $-0,33$ & 0,01 & 0,03 & \\
\hline CCA & 0,31 & $-0,43$ & 0,15 & 0,15 & 0,04 & & 0,00 & $-0,35$ & $-0,41$ & $-0,38$ & \\
\hline PCF & - & - & . & - & - & - & - & - & - & - & \\
\hline PED & $-0,27$ & $-0,11$ & 0,70 & 0,70 & 0,60 & & 0,05 & $-0,15$ & $-0,03$ & 0,00 & \\
\hline CIN & 0,20 & $-0,13$ & $-0,69$ & $-0,69$ & $-0,86$ & & $-0,07$ & $-0,14$ & $-0,34$ & $-0,34$ & \\
\hline CPR & $-0,07$ & 0,08 & $-0,63$ & $-0,63$ & $-0,23$ & & $-0,04$ & 0,18 & 0,09 & 0,08 & \\
\hline CCR & $-0,31$ & 0,43 & $-0,15$ & $-0,15$ & $-0,04$ & & 0,00 & 0,35 & 0,41 & 0,38 & \\
\hline CPO & 0,44 & $-0,77$ & 0,28 & 0,28 & $-0,28$ & & $-0,14$ & $-0,73$ & $-0,61$ & $-0,59$ & \\
\hline \multirow[t]{3}{*}{ FOR } & 0,36 & $-0,43$ & 0,15 & 0,15 & $-0,30$ & & 0,00 & $-0,43$ & $-0,45$ & $-0,46$ & \\
\hline & & & & & & & & & & & \\
\hline & $\mathrm{CPL}$ & LPL & $\mathrm{CCJ}$ & $\mathrm{CCA}$ & PCF & PED & CIN & CPR & CCR & CPO & FOR \\
\hline CBF & - & - & - & - & - & - & - & - & - & - & . \\
\hline CFA & - & - & - & - & - & - & - & - & - & - & - \\
\hline CPE & - & - & - & - & - & - & - & - & - & - & - \\
\hline CBN & - & - & - & - & - & - & - & - & - & - & - \\
\hline MLF & - & - & - & - & - & - & - & - & - & - & - \\
\hline SLF & - & - & - & - & - & - & - & - & - & - & - \\
\hline NLF & - & - & - & - & - & - & - & - & - & - & 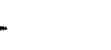 \\
\hline COF & - & - & - & - & - & - & - & - & - & - & - \\
\hline COP & - & - & - & - & - & - & - & - & - & - & - \\
\hline CLM & - & - & - & - & - & - & - & - & - & - & - \\
\hline LLM & - & - & - & - & - & - & - & - & - & - & - \\
\hline CPL & 1,00 & & - & - & - & - & - & - & - & - & - \\
\hline LPL & 0,67 & $1,00=$ & & - & - & - & - & - & - & - & - \\
\hline $\mathrm{CCJ}$ & $-0,01$ & $-0,52$ & 1,00 & - & - & - & - & - & - & - & - \\
\hline $\mathrm{CCA}$ & $-0,38$ & $-0,13$ & $-0,10$ & 1,00 & - & - & - & - & - & - & - \\
\hline PCF & - & - & - & - & 1,00 & - & - & - & - & - & - \\
\hline PED & $-0,06$ & $-0,48$ & 0,58 & 0,30 & & $1,00-$ & & - & - & - & 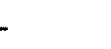 \\
\hline CIN & $-0,27$ & 0,23 & $-0,71$ & 0,26 & & $-0,75$ & $1,00-$ & - & - & - & - \\
\hline CPR & 0,09 & 0,46 & $-0,48$ & $-0,45$ & & $-0,76$ & 0,35 & $1,00-$ & & - & - \\
\hline CCR & 0,38 & 0,13 & 0,10 & $-1,00$ & & $-0,30$ & $-0,26$ & 0,45 & $1,00-$ & - & - \\
\hline $\mathrm{CPO}$ & $-0,54$ & $-0,37$ & 0,23 & 0,55 & & $-0,12$ & 0,46 & $-0,22$ & $-0,55$ & 1,00 & - \\
\hline FOR & $-0,39$ & $-0,32$ & 0,05 & 0,55 & & 0,26 & 0,26 & $-0,71$ & $-0,55$ & 0,55 & 1,00 \\
\hline
\end{tabular}


APÉNDICE 11. Correlações de Spearman entre cada par de caracteres entre etnovariedades da localidade de Ariri2 roça 1.

\begin{tabular}{|c|c|c|c|c|c|c|c|c|c|c|c|}
\hline Variável & CBF & CFA & CPE & CBN & MLF & SLF & NLF & COF & $\mathrm{COP}$ & $\overline{C L M}$ & LLM \\
\hline $\mathrm{CBF}$ & 1,00 & & - & - & - & - & - & - & - & - & $\overline{-}$ \\
\hline CFA & 0,38 & $1,00$. & & - & - & - & - & - & - & - & - \\
\hline CPE & 0,49 & 0,50 & 1,00 & & - & - & - & - & - & - & - \\
\hline CBN & 0,37 & 0,32 & 0,96 & $1,00-$ & & - & - & - & - & - & - \\
\hline MLF & 0,39 & 0,57 & 0,26 & 0,03 & $1,00-$ & & - & - & - & - & - \\
\hline SLF & - & - & - & 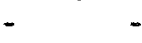 & - & 1,00 & - & - & - & - & - \\
\hline NLF & 0,16 & 0,20 & $-0,22$ & $-0,39$ & $0,53-$ & & $1,00$. & - & - & - & - \\
\hline COF & 0,06 & 0,02 & $-0,29$ & $-0,39$ & $0,33=$ & & 0,51 & 1,00 & - & - & - \\
\hline COP & 0,12 & 0,19 & 0,00 & $-0,12$ & $0,45-$ & & 0,46 & 0,67 & $1,00-$ & - & - \\
\hline CLM & $-0,22$ & $-0,14$ & $-0,48$ & $-0,49$ & $0,06-$ & & 0,31 & 0,77 & 0,60 & 1,00 & - \\
\hline LLM & $-0,13$ & $-0,27$ & $-0,52$ & $-0,51$ & $-0,35-$ & & 0,11 & 0,31 & 0,08 & 0,43 & 1,00 \\
\hline CPL & $-0,06$ & $-0,14$ & $-0,38$ & $-0,41$ & $0,11-$ & & 0,21 & 0,72 & 0,49 & 0,86 & 0,52 \\
\hline LPL & 0,01 & $-0,14$ & $-0,33$ & $-0,37$ & $-0,17-$ & & 0,13 & 0,28 & 0,13 & 0,39 & 0,87 \\
\hline $\mathrm{CCJ}$ & 0,51 & 0,39 & 0,89 & 0,91 & $0,10-$ & & $-0,28$ & $-0,33$ & $-0,15$ & $-0,47$ & $-0,55$ \\
\hline CCA & 0,04 & $-0,23$ & 0,56 & 0,73 & $-0,19-$ & & $-0,48$ & $-0,34$ & $-0,23$ & $-0,28$ & $-0,46$ \\
\hline PCF & $-0,06$ & $-0,49$ & $-0,56$ & $-0,48$ & $-0,28-$ & & 0,12 & 0,18 & $-0,20$ & 0,11 & 0,43 \\
\hline PED & 0,12 & 0,05 & 0,32 & 0,33 & $0,08-$ & & $-0,27$ & $-0,17$ & $-0,06$ & $-0,32$ & $-0,31$ \\
\hline $\mathrm{CIN}$ & $-0,26$ & $-0,15$ & 0,31 & 0,42 & $-0,07-$ & & $-0,38$ & $-0,13$ & 0,01 & 0,01 & $-0,54$ \\
\hline CPF & 0,23 & $-0,12$ & 0,39 & 0,48 & $-0,20-$ & & $-0,29$ & $-0,43$ & $-0,34$ & $-0,42$ & 0,18 \\
\hline CCR & 0,45 & 0,35 & 0,81 & 0,82 & $0,09-$ & & $-0,21$ & $-0,49$ & $-0,18$ & $-0,57$ & $-0,64$ \\
\hline CPO & 0,12 & $-0,06$ & 0,20 & 0,25 & $-0,10-$ & & $-0,11$ & $-0,35$ & $-0,08$ & $-0,17$ & 0,15 \\
\hline
\end{tabular}

cont.

\begin{tabular}{llllllllllll} 
& LLM & CPL & LPL & CCJ & CCA & PCF & PED & CIN & CPR & CCR & CPO \\
CBF & - & - & - & - & - & - & - & - & - & - & - \\
CFA & - & - & - & - & - & - & - & - & - & - & - \\
CPE & - & - & - & - & - & - & - & - & - & - & - \\
CBN & - & - & - & - & - & - & - & - & - & - & - \\
MLF & - & - & - & - & - & - & - & - & - & - & - \\
SLF & - & - & - & - & - & - & - & - & - & - & - \\
NLF & - & - & - & - & - & - & - & - & - & - & - \\
COF & - & - & - & - & - & - & - & - & - & - & - \\
COP & - & - & - & - & - & - & - & - & - & - & - \\
CLM & - & - & - & - & - & - & - & - & - & - & - \\
LLM & 1,00 & - & - & - & - & - & - & - & - & - \\
CPL & 0,52 & $1,00-$ & - & - & - & - & - & - & - & - \\
LPL & 0,87 & 0,56 & $1,00-$ & - & - & - & - & - & - & - \\
CCJ & $-0,55$ & $-0,37$ & $-0,37$ & $1,00-$ & - & - & - & - & - & - \\
CCA & $-0,46$ & $-0,20$ & $-0,42$ & 0,62 & $1,00-$ & - & - & - & - & - \\
PCF & 0,43 & 0,21 & 0,26 & $-0,41$ & $-0,20$ & $1,00-$ & - & - & - & - \\
PED & $-0,31$ & $-0,29$ & $-0,22$ & 0,30 & 0,33 & $-0,16$ & $1,00-$ & - & - & - \\
CIN & $-0,54$ & $-0,06$ & $-0,48$ & 0,43 & 0,68 & $-0,29$ & 0,23 & $1,00-$ & - & - \\
CPR & 0,18 & $-0,23$ & 0,21 & 0,33 & 0,48 & 0,08 & 0,16 & $-0,13$ & $1,00-$ & - \\
CCR & $-0,64$ & $-0,51$ & $-0,45$ & 0,90 & 0,57 & $-0,45$ & 0,27 & 0,32 & 0,31 & $1,00-$ \\
CPO & 0,15 & 0,08 & 0,28 & 0,21 & 0,25 & $-0,04$ & 0,08 & $-0,07$ & 0,51 & 0,30 & 1,00 \\
\hline
\end{tabular}


APÊNDICE 12. Correlações de Spearman entre cada par de caracteres entre etnovariedades da localidade de Ariri2 roça 3.

\begin{tabular}{|c|c|c|c|c|c|c|c|c|c|}
\hline & Variável CBF & CFA & $\mathrm{CPE}$ & $\mathrm{CBN}$ & MLF & NLF & COF & $\mathrm{COP}$ & $\overline{C L M}$ \\
\hline$\overline{\mathrm{CBF}}$ & 1,00 & & & & & & & & \\
\hline CFA & $-0,80$ & 1,00 & & & & & & & \\
\hline CPE & $-0,98$ & 0,91 & 1,00 & & & & & & \\
\hline $\mathrm{CBN}$ & $-1,00$ & 0,80 & 0,98 & 1,00 & & & & & \\
\hline MLF & $-0,41$ & 0,51 & 0,46 & 0,41 & 1,00 & & & & \\
\hline SLF & 0,00 & 0,00 & 0,00 & 0,00 & 0,00 & $1,00-$ & & & \\
\hline NLF & 0,34 & $-0,47$ & $-0,41$ & $-0,34$ & $-0,24-$ & 1,00 & & & \\
\hline $\mathrm{COF}$ & 0,34 & $-0,26$ & $-0,33$ & $-0,34$ & $-0,40-$ & 0,29 & 1,00 & & \\
\hline COP & 0,19 & $-0,18$ & $-0,19$ & $-0,19$ & $-0,25-$ & 0,21 & 0,88 & 1,00 & \\
\hline CLM & 0,42 & $-0,30$ & $-0,40$ & $-0,42$ & $-0,46-$ & 0,37 & 0,91 & 0,65 & 1,00 \\
\hline LLM & 0,65 & $-0,76$ & $-0,72$ & $-0,65$ & $-0,52-$ & 0,53 & 0,67 & 0,50 & 0,70 \\
\hline CPL & 0,53 & $-0,44$ & $-0,53$ & $-0,53$ & $-0,46-$ & 0,47 & 0,87 & 0,63 & 0,95 \\
\hline LPL & 0,70 & $-0,74$ & $-0,75$ & $-0,70$ & $-0,43-$ & 0,48 & 0,69 & 0,57 & 0,66 \\
\hline $\mathrm{CCJ}$ & $-0,98$ & 0,91 & 1,00 & 0,98 & $0,46-$ & $-0,41$ & $-0,33$ & $-0,19$ & $-0,40$ \\
\hline CCA & $-0,80$ & 0,52 & 0,74 & 0,80 & $-0,22-$ & $-0,21$ & $-0,09$ & $-0,04$ & $-0,15$ \\
\hline PCF & 0,51 & $-0,03$ & $-0,36$ & $-0,51$ & $-0,33-$ & $-0,03$ & 0,23 & 0,01 & 0,40 \\
\hline PED & 0,28 & $-0,35$ & $-0,32$ & $-0,28$ & $0,08-$ & 0,16 & $-0,18$ & $-0,26$ & $-0,10$ \\
\hline CIN & $-0,36$ & 0,49 & 0,42 & 0,36 & $-0,17-$ & $-0,36$ & $-0,22$ & $-0,33$ & $-0,11$ \\
\hline CPR & $-0,41$ & $-0,22$ & 0,20 & 0,41 & $-0,11-$ & 0,15 & $-0,14$ & $-0,03$ & $-0,23$ \\
\hline CCR & $-0,90$ & 0,66 & 0,86 & 0,90 & 0,10 & $-0,28$ & $-0,17$ & $-0,03$ & $-0,30$ \\
\hline CPO & 0,00 & 0,00 & 0,00 & 0,00 & $0,00-$ & 0,00 & 0,00 & 0,00 & 0,00 \\
\hline
\end{tabular}

cont.

\begin{tabular}{|c|c|c|c|c|c|c|c|c|c|c|c|}
\hline \multicolumn{12}{|l|}{$\begin{array}{l}\text { CBF } \\
\text { CFA }\end{array}$} \\
\hline \multicolumn{12}{|l|}{ CPE } \\
\hline \multicolumn{12}{|l|}{ CBN } \\
\hline \multicolumn{12}{|l|}{ MLF } \\
\hline \multicolumn{12}{|l|}{ SLF } \\
\hline \multicolumn{12}{|l|}{ NLF } \\
\hline \multicolumn{12}{|l|}{ COF } \\
\hline \multicolumn{12}{|l|}{ COP } \\
\hline \multicolumn{12}{|l|}{ CLM } \\
\hline LLM & 1,00 & & & & & & & & & & \\
\hline CPL & 0,74 & 1,00 & & & & & & & & & \\
\hline LPL & 0,81 & 0,77 & 1,00 & & & & & & & & \\
\hline CCJ & $-0,72$ & $-0,53$ & $-0,75$ & 1,00 & & & & & & & \\
\hline CCA & $-0,35$ & $-0,27$ & $-0,46$ & 0,74 & 1,00 & & & & & & \\
\hline PCF & 0,12 & 0,32 & 0,17 & $-0,36$ & $-0,34$ & 1,00 & & & & & \\
\hline PED & 0,22 & $-0,02$ & 0,22 & $-0,32$ & $-0,35$ & $-0,10$ & 1,00 & & & & \\
\hline $\mathrm{CIN}$ & $-0,38$ & $-0,23$ & $-0,50$ & 0,42 & 0,49 & 0,21 & 0,11 & 1,00 & & & \\
\hline CPR & 0,10 & $-0,19$ & $-0,01$ & 0,20 & 0,51 & $-0,79$ & 0,08 & $-0,17$ & 1,00 & & \\
\hline CCR & $-0,49$ & $-0,37$ & $-0,56$ & 0,86 & 0,89 & $-0,57$ & $-0,31$ & 0,42 & 0,45 & 1,00 & \\
\hline CPO & 0,00 & 0,00 & 0,00 & 0,00 & 0,00 & 0,00 & 0,00 & 0,00 & 0,00 & 0,00 & 1,00 \\
\hline
\end{tabular}


APÊNDICE 13. Componentes principais extraídos dos dados da roça 1 (Ariri 1), seus autovalores, proporção da variância total e proporção cumulativa da variância.

\begin{tabular}{llll}
\hline Variável & Autovalor & Proporção (\%) & Cumulativo (\%) \\
\hline Comp1 & 6,82101 & 35,9 & 35,9 \\
Comp2 & 3,20887 & 16,89 & 52,79 \\
Comp3 & 3,11779 & 16,41 & 69,2 \\
Comp4 & 2,11059 & 11,11 & 80,31 \\
Comp5 & 1,56945 & 8,26 & 88,57 \\
Comp6 & 1,11732 & 5,88 & 94,45 \\
Comp7 & 0,53025 & 2,79 & 97,24 \\
Comp8 & 0,2033 & 1,07 & 98,31 \\
Comp9 & 0,17789 & 0,94 & 99,24 \\
Comp10 & 0,07865 & 0,41 & 99,66 \\
Comp11 & 0,0442 & 0,23 & 99,89 \\
Comp12 & 0,01218 & 0,06 & 99,96 \\
Comp13 & 0,00513 & 0,03 & 99,98 \\
Comp14 & 0,00337 & 0,02 & 100 \\
\hline
\end{tabular}

APÊNDICE 14. Componentes principais extraídos dos dados da roça 2 (Ariri 1), seus autovalores, proporção da variância total e proporção cumulativa da variância.

\begin{tabular}{llll}
\hline Variável & Autovalor & Proporção (\%) & Cumulativo (\%) \\
\hline Comp1 & 12,19411 & 64,18 & 64,18 \\
Comp2 & 4,32808 & 22,78 & 86,96 \\
Comp3 & 1,42047 & 7,48 & 94,44 \\
Comp4 & 0,76328 & 4,02 & 98,45 \\
Comp5 & 0,14518 & 0,76 & 99,22 \\
Comp6 & 0,09092 & 0,48 & 99,69 \\
Comp7 & 0,03999 & 0,21 & 99,91 \\
Comp8 & 0,01489 & 0,08 & 99,98 \\
Comp9 & 0,00308 & 0,02 & 100,00 \\
\hline APÉND1CE & 15. Componentes principais & extraídos dos dados \\
autovalores, proporção da variância total e proporção cumulativa da var & \\
\hline Variável & Autovalor & Proporçăo (\%) & Cumulativo (\%) \\
\hline Comp1 & 7,71698 & 38,58 & 38,58 \\
Comp2 & 5,20686 & 26,03 & 64,62 \\
Comp3 & 2,61394 & 13,07 & 77,69 \\
Comp4 & 1,47137 & 7,36 & 85,05 \\
Comp5 & 1,15767 & 5,79 & 90,83 \\
Comp6 & 0,85540 & 4,28 & 95,11 \\
Comp7 & 0,62954 & 3,15 & 98,26 \\
Comp8 & 0,26729 & 1,34 & 99,60 \\
Comp9 & 0,04508 & 0,23 & 99,82 \\
Comp10 & 0,01772 & 0,09 & 99,91 \\
Comp11 & 0,01245 & 0,06 & 99,97 \\
Comp12 & 0,00363 & 0,02 & 99,99 \\
Comp13 & 0,00206 & 0,01 & 100,00 \\
\hline
\end{tabular}


APENDICE 16. Componentes principais extraídos dos dados da roça 1 (Ariri 2), seus autovalores, proporção da variância total e proporção cumulativa da variância.

\begin{tabular}{llll}
\hline Variável & autovalor & Proporção (\%) & Cumulativo (\%) \\
\hline Comp1 & 6,96336 & 34,82 & 34,82 \\
Comp2 & 3,40794 & 17,04 & 51,86 \\
Comp3 & 2,43538 & 12,18 & 64,03 \\
Comp4 & 1,82251 & 9,11 & 73,15 \\
Comp5 & 1,14174 & 5,71 & 78,85 \\
Comp6 & 0,91618 & 4,58 & 83,44 \\
Comp7 & 0,85964 & 4,30 & 87,73 \\
Comp8 & 0,58272 & 2,91 & 90,65 \\
Comp9 & 0,50671 & 2,53 & 93,18 \\
Comp10 & 0,35830 & 1,79 & 94,97 \\
Comp11 & 0,30225 & 1,51 & 96,48 \\
Comp12 & 0,21017 & 1,05 & 97,53 \\
Comp13 & 0,18979 & 0,95 & 98,48 \\
Comp14 & 0,10356 & 0,52 & 99,00 \\
Comp15 & 0,08406 & 0,42 & 99,42 \\
Comp16 & 0,04278 & 0,21 & 99,64 \\
Comp17 & 0,03492 & 0,17 & 99,81 \\
Comp18 & 0,02380 & 0,12 & 99,93 \\
Comp19 & 0,01274 & 0,06 & 99,99 \\
Comp20 & 0,00138 & 0,01 & 100,00 \\
\hline
\end{tabular}

APÊNDICE 17. Componentes principais extraídos dos dados da roça 3 (Ariri 2), seus autovalores, proporção da variância total e proporção cumulativa da variância.

\begin{tabular}{llll}
\hline Variável & Autovalor & Proporção (\%) & Cumulativo (\%) \\
\hline Comp1 & 9,37684 & 49,35 & 49,35 \\
Comp2 & 3,10521 & 16,34 & 65,70 \\
Comp3 & 2,45668 & 12,93 & 78,62 \\
Comp4 & 1,49568 & 7,87 & 86,50 \\
Comp5 & 0,95430 & 5,02 & 91,52 \\
Comp6 & 0,77023 & 4,05 & 95,57 \\
Comp7 & 0,26688 & 1,40 & 96,98 \\
Comp8 & 0,20721 & 1,09 & 98,07 \\
Comp9 & 0,14794 & 0,78 & 98,85 \\
Comp10 & 0,09168 & 0,48 & 99,33 \\
Comp11 & 0,07837 & 0,41 & 99,74 \\
Comp12 & 0,03513 & 0,18 & 99,93 \\
Comp13 & 0,01385 & 0,07 & 100,00 \\
\hline
\end{tabular}


APÉNDICE 18. Componentes principais extraídos dos dados da roça 3 (Ariri 2), seus autovalores, proporção da variância total e proporção cumulativa da variância, a partir do conjunto simplificado de variáveis.

\begin{tabular}{llll}
\hline Variável & Autovalor & Proporção (\%) & Cumulativo (\%) \\
\hline Comp1 & 6,79625 & 56,64 & 56,64 \\
Comp2 & 1,89512 & 15,79 & 72,43 \\
Comp3 & 1,40404 & 11,70 & 84,13 \\
Comp4 & 0,86303 & 7,19 & 91,32 \\
Comp5 & 0,61257 & 5,10 & 96,43 \\
Comp6 & 0,33952 & 2,83 & 99,25 \\
Comp7 & 0,08947 & 0,75 & 100,00 \\
\hline
\end{tabular}


APÊNDICE 19. Similaridades entre todas as amostras da roca 1 de Ariri1.

\begin{tabular}{|c|c|c|c|c|c|c|c|c|c|c|c|c|c|c|c|c|c|c|c|c|}
\hline Amostra & A1 & $\mathrm{A2}$ & $\overline{A 3}$ & A4 & A5 & A7 & A9 & A10 & A12 & A13 & A14 & $\mathbf{A 1 5}$ & $A 16$ & A18 & A22 & A24 & A27 & A28 & A29 & A30 \\
\hline$\overline{\mathrm{A1}}$ & 1,00 & & & & & & & & & & & & & & & & & & & \\
\hline A2 & 0,95 & 1,00 & & & & & & & & & & & & & & & & & & \\
\hline A3 & 0,92 & 0,97 & 1,00 & & & & & & & & & & & & & & & & & \\
\hline A4 & 0,90 & 0,90 & 0,92 & 1,00 & & & & & & & & & & & & & & & & \\
\hline A5 & 0,95 & 0,95 & 0,97 & 0,95 & 1,00 & & & & & & & & & & & & & & & \\
\hline A7 & 0,92 & 0,87 & 0,90 & 0,97 & 0,92 & 1,00 & & & & & & & & & & & & & & \\
\hline A9 & 0,92 & 0,97 & 1,00 & 0,92 & 0,97 & 0,90 & 1,00 & & & & & & & & & & & & & \\
\hline A10 & 0,92 & 0,97 & 1,00 & 0,92 & 0,97 & 0,90 & 1,00 & 1,00 & & & & & & & & & & & & \\
\hline A12 & 0,95 & 1,00 & 0,97 & 0,90 & 0,95 & 0,87 & 0,97 & 0,97 & 1,00 & & & & & & & & & & & \\
\hline A13 & 0,92 & 0,97 & 1,00 & 0,92 & 0,97 & 0,90 & 1,00 & 1,00 & 0,97 & 1,00 & & & & & & & & & & \\
\hline A14 & 0,85 & 0,90 & 0,92 & 0,95 & 0,90 & 0,92 & 0,92 & 0,92 & 0,90 & 0,92 & 1,00 & & & & & & & & & \\
\hline A15 & 0,95 & 0,95 & 0,97 & 0,95 & 1,00 & 0,92 & 0,97 & 0,97 & 0,95 & 0,97 & 0,90 & 1,00 & & & & & & & & \\
\hline A16 & 0,92 & 0,97 & 1,00 & 0,92 & 0,97 & 0,90 & 1,00 & 1,00 & 0,97 & 1,00 & 0,92 & 0,97 & 1,00 & & & & & & & \\
\hline A18 & 0,90 & 0,85 & 0,87 & 0,95 & 0,90 & 0,97 & 0,87 & 0,87 & 0,85 & 0,87 & 0,95 & 0,90 & 0,87 & 1,00 & & & & & & \\
\hline A 22 & 0,95 & 0,95 & 0,97 & 0,95 & 1,00 & 0,92 & 0,97 & 0,97 & 0,95 & 0,97 & 0,90 & 1,00 & 0,97 & 0,90 & 1,00 & & & & & \\
\hline A24 & 0,92 & 0,97 & 1,00 & 0,92 & 0,97 & 0,90 & 1,00 & 1,00 & 0,97 & 1,00 & 0,92 & 0,97 & 1,00 & 0,87 & 0,97 & 1,00 & & & & \\
\hline A27 & 0,79 & 0,79 & 0,82 & 0,90 & 0,85 & 0,87 & 0,82 & 0,82 & 0,79 & 0,82 & 0,85 & 0,85 & 0,82 & 0,85 & 0,85 & 0,82 & 1,00 & & & \\
\hline A28 & 0,90 & 0,85 & 0,82 & 0,85 & 0,85 & 0,87 & 0,82 & 0,82 & 0,85 & 0,82 & 0,79 & 0,85 & 0,82 & 0,85 & 0,85 & 0,82 & 0,85 & 1,00 & & \\
\hline A29 & 0,92 & 0,97 & 1,00 & 0,92 & 0,97 & 0,90 & 1,00 & 1,00 & 0,97 & 1,00 & 0,92 & 0,97 & 1,00 & 0,87 & 0,97 & 1,00 & 0,82 & 0,82 & 1,00 & \\
\hline A30 & 0,97 & 0,92 & 0,95 & 0,92 & 0,97 & 0,95 & 0,95 & 0,95 & 0,92 & 0,95 & 0,87 & 0,97 & 0,95 & 0,92 & 0,97 & 0,95 & 0,82 & 0,87 & 0,95 & 1,00 \\
\hline
\end{tabular}


APÊNDICE 20. Similaridades entre todas as amostras da roça 2 de Ariri1.

\begin{tabular}{|c|c|c|c|c|c|c|c|c|c|c|c|c|}
\hline Amostra & B31 & B35 & B36 & B37 & B39 & B40 & B41 & $B 42$ & B46 & BA7 & 848 & $\mathrm{~B} 50$ \\
\hline$\overline{\text { B31 }}$ & 1,00 & & & & & & & & & & & \\
\hline B35 & 1,00 & 1,00 & & & & & & & & & & \\
\hline B36 & 0,97 & 0,97 & 1,00 & & & & & & & & & \\
\hline B37 & 0,95 & 0,95 & 0,97 & 1,00 & & & & & & & & \\
\hline B39 & 0,92 & 0,92 & 0,95 & 0,92 & 1,00 & & & & & & & \\
\hline B40 & 1,00 & 1,00 & 0,97 & 0,95 & 0,92 & 1,00 & & & & & & \\
\hline B41 & 0,95 & 0,95 & 0,97 & 1,00 & 0,92 & 0,95 & 1,00 & & & & & \\
\hline B42 & 0,85 & 0,85 & 0,82 & 0,85 & 0,77 & 0,85 & 0,85 & 1,00 & & & & \\
\hline B46 & 1,00 & 1,00 & 0,97 & 0,95 & 0,92 & 1,00 & 0,95 & 0,85 & 1,00 & & & \\
\hline B47 & 0,97 & 0,97 & 1,00 & 0,97 & 0,95 & 0,97 & 0,97 & 0,82 & 0,97 & 1,00 & & \\
\hline$B 48$ & 0,87 & 0,87 & 0,85 & 0,87 & 0,90 & 0,87 & 0,87 & 0,82 & 0,87 & 0,85 & 1,00 & \\
\hline B50 & 1,00 & 1,00 & 0,97 & 0,95 & 0,92 & 1,00 & 0,95 & 0,85 & 1,00 & 0,97 & 0,87 & 1,00 \\
\hline
\end{tabular}

APÊNDICE 21. Similaridades entre todas as amostras da roca 3 de Ariri1.

\begin{tabular}{|c|c|c|c|c|c|c|c|c|c|c|c|c|c|c|c|c|c|}
\hline Amostra & C51 & C52 & C53 & C54 & C55 & C57 & $\overline{C 58}$ & $\mathrm{C60}$ & $\mathrm{C61}$ & C62 & $\mathrm{C63}$ & $\mathrm{C66}$ & C68 & C72 & C74 & C77 & C79 \\
\hline$\overline{\mathrm{C51}}$ & 1,00 & & & & & & & & & & & & & & & & \\
\hline C52 & 0,74 & 1,00 & & & & & & & & & & & & & & & \\
\hline C53 & 0,87 & 0,72 & ? 1,00 & & & & & & & & & & & & & & \\
\hline C54 & 0,90 & 0,69 & 0,92 & 1,00 & & & & & & & & & & & & & \\
\hline C55 & 0,97 & 0,72 & 0,90 & 0,92 & 1,00 & & & & & & & & & & & & \\
\hline $\mathrm{C57}$ & 0,85 & 0,90 & 0,77 & 0,74 & 0,82 & 1,00 & & & & & & & & & & & \\
\hline C58 & 0,85 & 0,90 & 0,77 & 0,74 & 0,82 & 1,00 & 1,00 & & & & & & & & & & \\
\hline $\mathrm{C60}$ & 0,74 & 1,00 & 0,72 & 0,69 & 0,72 & 0,90 & 0,90 & 1,00 & & & & & & & & & \\
\hline C61 & 0,90 & 0,79 & 0,87 & 0,90 & 0,87 & 0,85 & 0,85 & 0,79 & 1,00 & & & & & & & & \\
\hline $\mathrm{C62}$ & 0,77 & 0,97 & 0,74 & 0,72 & 0,74 & 0,92 & 0,92 & 0,97 & 0,82 & 1,00 & & & & & & & \\
\hline C63 & 0,87 & 0,77 & 0,90 & 0,87 & 0,85 & 0,82 & 0,82 & 0,77 & 0,87 & 0,79 & 1,00 & & & & & & \\
\hline $\mathrm{C66}$ & 0,77 & 0,97 & 0,74 & 0,72 & 0,74 & 0,92 & 0,92 & 0,97 & 0,82 & 1,00 & 0,79 & 1,00 & & & & & \\
\hline $\mathrm{C68}$ & 0,85 & 0,90 & 0,77 & 0,74 & 0,82 & 1,00 & 1,00 & 0,90 & 0,85 & 0,92 & 0,82 & 0,92 & 1,00 & & & & \\
\hline $\mathrm{C} 72$ & 0,74 & 1,00 & 0,72 & 0,69 & 0,72 & 0,90 & 0,90 & 1,00 & 0,79 & 0,97 & 0,77 & 0,97 & 0,90 & 1,00 & & & \\
\hline C74 & 0,90 & 0,74 & 0,87 & 0,90 & 0,92 & 0,85 & 0,85 & 0,74 & $4 \quad 0,79$ & 0,77 & 0,77 & 0,77 & 0,85 & ; 0,74 & 1,00 & & \\
\hline $\mathrm{C77}$ & 0,74 & 1,00 & 0,72 & 0,69 & 0,72 & 0,90 & 0,90 & 1,00 & 0,79 & 0,97 & 0,77 & 0,97 & 0,90 & 1,00 & 0,74 & 1,00 & \\
\hline C79 & 0,74 & 1,00 & 0,72 & 0,69 & 0,72 & 0,90 & 0,90 & 1,00 & 0,79 & 0,97 & 0,77 & 0,97 & 0,90 & 1,00 & 0,74 & 1,00 & 1,00 \\
\hline
\end{tabular}


APÊNDICE 22. Similaridades entre todas as amostras da roça 1 de Ariri2.

\begin{tabular}{|c|c|c|c|c|c|c|c|c|c|c|c|c|c|c|c|c|c|c|c|c|c|c|c|c|c|c|c|c|c|c|c|c|}
\hline Amososs & cal & M02 & $\overline{c s}$ & हब & c & cos & प10 & c & Aat & casio & AO11 & MD12 0 & 9130 & c14 & cis & Con & C17 & 0010 & cote 0 & cre & now e & 0022 & 0023 & $\operatorname{mox}$ of & c023 सI & nax $\mathrm{cx}$ & $627 \quad$ WI & yon co & $\cos 2 \mu$ & Aust cor & CAH & on \\
\hline cor & 1,00 & & & & & & & & & & & & & & & & & & & & & & & & & & & & & & & \\
\hline MDz & 0,90 & 1,00 & & & & & & & & & & & & & & & & & & & & & & & & & & & & & & \\
\hline cs & 0,86 & 0,90 & 1,00 & & & & & & & & & & & & & & & & & & & & & & & & & & & & & \\
\hline cas & 0,85 & 0,95 & 0,90 & 1,00 & & & & & & & & & & & & & & & & & & & & & & & & & & & & \\
\hline cs & 0,86 & 0.90 & 1,00 & 0,80 & 1.00 & & & & & & & & & & & & & & & & & & & & & & & & & & & \\
\hline cas & 0,95 & 0,95 & 0,90 & 1,00 & 0,80 & 1,00 & & & & & & & & & & & & & & & & & & & & & & & & & & \\
\hline mor & 0,90 & 1,00 & 0,90 & 0,95 & 0,90 & 0,95 & 1,00 & & & & & & & & & & & & & & & & & & & & & & & & & \\
\hline co & 0,86 & 0,90 & 1,00 & 0,90 & 1,00 & 0,90 & 0,90 & 1,00 & & & & & & & & & & & & & & & & & & & & & & & & \\
\hline Aos & 0,86 & 0,95 & 0,86 & 0,90 & 0,86 & 0,90 & 0,85 & 0,86 & 1,00 & & & & & & & & & & & & & & & & & & & & & & & \\
\hline cote & 1,00 & 0,90 & 0,86 & 0,85 & 0,86 & 0,95 & 0,90 & 0,86 & 0,86 & 1,00 & & & & & & & & & & & & & & & & & & & & & & \\
\hline AOAt & 0,86 & 0,95 & 0,86 & 0,90 & 0,86 & 0,80 & 0,95 & 0,86 & 1,00 & 0,86 & 1,00 & & & & & & & & & & & & & & & & & & & & & \\
\hline wotz & 0,95 & 0,85 & 0,86 & 0,90 & 0,86 & 0,90 & 0,95 & 0,86 & 0,90 & 0,95 & 0,90 & 1,00 & & & & & & & & & & & & & & & & & & & & \\
\hline (1) & 0,86 & 0,90 & 1.00 & 0,90 & 1,00 & 0,90 & 0,90 & 1,00 & 0,86 & 0,86 & 0,86 & 0,86 & 1,00 & & & & & & & & & & & & & & & & & & & \\
\hline c14 & 0,86 & 0,90 & 1,00 & 0,90 & 1,00 & 0,90 & 0,90 & 1,00 & 0,86 & 0,86 & 0,86 & 0,86 & 1,00 & 1,00 & & & & & & & & & & & & & & & & & & \\
\hline e15 & 0,86 & 0,90 & 1,00 & 0,90 & 1,00 & 0,80 & 0,90 & 1,00 & 0,86 & 0,86 & 0,86 & 0,86 & 1,00 & 1,00 & 1,00 & & & & & & & & & & & & & & & & & \\
\hline cors & 0,95 & 0,95 & 0,80 & 1,00 & 0,80 & 1,00 & 0,95 & 0,90 & 0,80 & 0,95 & 0,90 & 0,90 & 0,90 & 0,90 & 0,90 & 1,00 & & & & & & & & & & & & & & & & \\
\hline c17 & 0,80 & 0,86 & 0,85 & 0.86 & 0,95 & 0,86 & 0,86 & 0,95 & 0,81 & 0,90 & 0,81 & 0,90 & 0,95 & 0,95 & 0,95 & 0,86 & 1,00 & & & & & & & & & & & & & & & \\
\hline cort: & 0,95 & 0,95 & 0,90 & 1,00 & 0,80 & 1,00 & 0,95 & 0,90 & 0,90 & 0,95 & 0,90 & 0,90 & 0,90 & 0,90 & 0,90 & 1,00 & 0,86 & 1,00 & & & & & & & & & & & & & & \\
\hline co10 & 0,95 & 0,95 & 0,80 & 1,00 & 0,90 & 1,00 & 0,95 & 0,90 & 0,90 & 0,95 & 0,90 & 0,90 & 0,90 & 0,90 & 0,90 & 1,00 & 0,86 & 1,00 & 1,00 & & & & & & & & & & & & & \\
\hline C20 & 0,86 & 0,90 & 1,00 & 0,90 & 1,00 & 0,90 & 0,90 & 1,00 & 0,86 & 0,86 & 0,86 & 0,86 & 1,00 & 1,00 & 1,00 & 0,90 & 0,95 & 0,90 & 0,90 & 1,00 & & & & & & & & & & & & \\
\hline Mo81 & 0,90 & 1,00 & 0,90 & 0,95 & 0,90 & 0,95 & 1,00 & 0,90 & 0,95 & 0,90 & 0.95 & 0,95 & 0,90 & 0,90 & 0,90 & 0.95 & 0,86 & 0,95 & 0,95 & 0,901 & 1,00 & & & & & & & & & & & \\
\hline $\operatorname{cos2}$ & 0,95 & 0,95 & 0,90 & 1,00 & 0,90 & 1,00 & 0,95 & 0,90 & 0,90 & 0,95 & 0,80 & 0,90 & 0,90 & 0,90 & 0,90 & 1,00 & 0,86 & 1,00 & 1,00 & 0,900 & 0,951 & 1,00 & & & & & & & & & & \\
\hline $\operatorname{coss}$ & 0,95 & 0,95 & 0,90 & 1,00 & 0,90 & 1,00 & 0,95 & 0,90 & 0,90 & 0,95 & 0,90 & 0,90 & 0,90 & 0,80 & 0,90 & 1,00 & 0,86 & 1,00 & 1,00 & 0,900 & 0,951 & 1,00 & 1,00 & & & & & & & & & \\
\hline 1020 & 0,90 & 1,00 & 0,90 & 0,95 & 0,90 & 0,95 & 1,00 & 0,90 & 0,95 & 0,90 & 0,95 & 0,95 & 0,90 & 0,90 & 0,90 & 0,95 & 0,86 & 0,95 & 0,95 & 0,901 & 1,000 & 0,950 & 0,951 & 1,00 & & & & & & & & \\
\hline Co24 & 1,00 & 0,90 & 0,86 & 0,95 & 0,86 & 0,95 & 0,90 & 0,86 & 0,86 & 1,00 & 0,86 & 0,95 & 0,86 & 0,86 & 0,86 & 0,95 & 0,90 & 0,95 & 0,95 & 0,860 & $0,90 \quad 0$ & 0,950 & 0,850 & 0,90 & 1,00 & & & & & & & \\
\hline 4026 & 0,80 & 1,00 & 0,90 & 0,95 & 0,90 & 0,95 & 1,00 & 0,80 & 0,95 & 0,90 & 0,95 & 0,95 & 0,90 & 0,90 & 0,80 & 0,95 & 0,86 & 0,85 & 0,95 & 0,901 & $1,00 \quad 0$ & 0,950 & 0,951 & 1,000 & $0,90 \quad 1$, & ,00 & & & & & & \\
\hline C27 & 0,86 & 0,90 & 1,00 & 0,90 & 1,00 & 0,90 & 0,90 & 1,00 & 0,86 & 0,86 & 0,86 & 0,86 & 1,00 & 1,00 & 1,00 & 0,90 & 0,95 & 0,90 & 0,90 & 1,000 & $0,90 \quad 0$ & $0,90 \quad 0$ & 0,900 & $0,90 \quad 0$ & 0,860, &, $90 \quad 1$ & 1,00 & & & & & \\
\hline mos: & 0,88 & 0,98 & 0,93 & 0,93 & 0,83 & 0,93 & 0,98 & 0,93 & 0,93 & 0,88 & 0,83 & 0,93 & 0,93 & 0,93 & 0,93 & 0,93 & 0,88 & 0,93 & 0,93 & 0,930 & $0,98 \quad 0$ & 0,830 & 0,930 & $0,98 \quad 0$ & $0,880$. & $0,98 \quad 0$ & 0,931 & 1,00 & & & & \\
\hline c020 & 1,00 & 0,90 & 0,86 & 0,95 & 0,86 & 0,95 & 0,90 & 0,86 & 0,86 & 1,00 & 0,86 & 0,95 & 0,86 & 0,86 & 0,86 & 0,95 & 0,90 & 0,95 & 0,95 & 0,860 & $0,90 \quad 0$ & 0,950 & 0,950 & 0,901 & $1,00 \quad 0$, &, $90 \quad 0$ & 0,860 & $0,88 \quad 1$, & .00 & & & \\
\hline $\cos 30$ & 0,83 & 0,83 & 0,74 & 0,79 & 0,74 & 0,79 & 0,83 & 0,74 & 0,88 & 0,83 & 0,88 & 0,88 & 0,740 & 0,74 & 0,74 & 0,79 & 0,79 & 0,79 & 0,79 & 0,740 & $\begin{array}{l}0,83 \quad 0 \\
\end{array}$ & 0,790 & 0.790 & $0,83 \quad 0$ & $0,83 \quad 0$, & 1830. & 0,740 & $\begin{array}{l}0,81 \quad 0,\end{array}$ & $83 \quad 1$ & 1,00 & & \\
\hline cst & 0,86 & 0,80 & 1,00 & 0,90 & 1,00 & 0,90 & 0,90 & 1,00 & 0,86 & 0,86 & 0,86 & 0,86 & 1,001 & 1,00 & 1,00 & 0,90 & 0,95 & 0,90 & 0,90 & 1,000 & $0,90 \quad 0$ & 0,900 & 0,900 & $0,90 \quad 0$ & 0,860, &, 801 . & 1,000 & $0,93 \quad 0$, & 1,860 & 0,741 & 1,00 & \\
\hline Ca2 & 0,86 & 0,90 & 1,00 & 0,90 & 1,00 & 0,90 & 0,90 & 1,00 & 0,86 & 0,86 & 0,86 & 0,86 & 1,001 & 1,00 & 1,00 & 0,80 & 0,95 & 0,80 & 0,90 & 1,000 & $0,90 \quad 0$ & 0,800 & 0,900 & $0,90 \quad 0$ & $0,86 \quad 0$, & $0,90 \quad 1$, &, 000 & 0,930, &, 880 & 0,741 & 1,001 & 1,00 \\
\hline
\end{tabular}


APÊNDICE 23. Similaridades entre todas as amostras da roça 2 de Ariri2.

\begin{tabular}{llllllllllllllll}
\hline Amostra & C33 & MD34 & C35 & AR36 & AR37 & AR38 & AG39 & AG40 & C41 & C42 & AR43 & C44 & C45 & C46 & AG47 \\
\hline C33 & 1,00 & & & & & & & & & & & & & & \\
MD34 & 0,90 & 1,00 & & & & & & & & & & & & \\
C35 & 1,00 & 0,90 & 1,00 & & & & & & & & & & & \\
AR36 & 0,90 & 0,95 & 0,90 & 1,00 & & & & & & & & & & \\
AR37 & 0,90 & 0,95 & 0,90 & 1,00 & 1,00 & & & & & & & & & \\
AR38 & 0,90 & 0,95 & 0,90 & 1,00 & 1,00 & 1,00 & & & & & & & & \\
AG39 & 0,86 & 0,90 & 0,86 & 0,95 & 0,95 & 0,95 & 1,00 & & & & & & & \\
AG40 & 0,86 & 0,90 & 0,86 & 0,95 & 0,95 & 0,95 & 1,00 & 1,00 & & & & & & \\
C41 & 1,00 & 0,90 & 1,00 & 0,90 & 0,90 & 0,90 & 0,86 & 0,86 & 1,00 & & & & & \\
C42 & 0,95 & 0,90 & 0,95 & 0,95 & 0,95 & 0,95 & 0,90 & 0,90 & 0,95 & 1,00 & & & & \\
AR43 & 0,81 & 0,86 & 0,81 & 0,81 & 0,81 & 0,81 & 0,86 & 0,86 & 0,81 & 0,81 & 1,00 & & & \\
C44 & 0,95 & 0,90 & 0,95 & 0,95 & 0,95 & 0,95 & 0,90 & 0,90 & 0,95 & 1,00 & 0,81 & 1,00 & & \\
C45 & 0,95 & 0,90 & 0,95 & 0,95 & 0,95 & 0,95 & 0,90 & 0,90 & 0,95 & 1,00 & 0,81 & 1,00 & 1,00 & \\
C46 & 0,95 & 0,90 & 0,95 & 0,95 & 0,95 & 0,95 & 0,90 & 0,90 & 0,95 & 1,00 & 0,81 & 1,00 & 1,00 & 1,00 & \\
AG47 & 0,90 & 1,00 & 0,90 & 0,95 & 0,95 & 0,95 & 0,90 & 0,90 & 0,90 & 0,90 & 0,86 & 0,90 & 0,90 & 0,90 & 1,00 \\
\hline
\end{tabular}




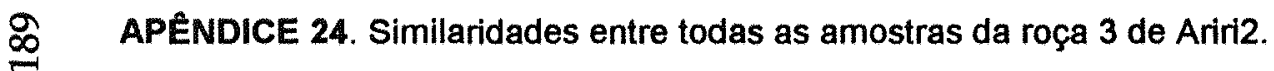

\begin{tabular}{|c|c|c|c|c|c|c|c|c|c|c|c|c|c|c|c|c|c|c|c|c|}
\hline Amostra & MD48 & $\mathbf{C 4 9}$ & $\mathbf{C 5 0}$ & AG51 & C52 & AG53 & $\overline{c 54}$ & C55 & C56 & CG57 & $\mathrm{C58}$ & C59 & C60 & $\mathrm{C61}$ & CG62 & $\mathrm{C63}$ & C64 & CG65 & CG66 & MD67 \\
\hline MD48 & 1,00 & & & & & & & & & & & & & & & & & & & \\
\hline C49 & 0,93 & 1,00 & & & & & & & & & & & & & & & & & & \\
\hline C50 & 0,93 & 1,00 & 1,00 & & & & & & & & & & & & & & & & & \\
\hline AG51 & 0,95 & 0,88 & 0,88 & 1,00 & & & & & & & & & & & & & & & & \\
\hline C52 & 0,93 & 1,00 & 1,00 & 0,88 & 1,00 & & & & & & & & & & & & & & & \\
\hline AG53 & 0,88 & 0,81 & 0,81 & 0,93 & 0,81 & 1,00 & & & & & & & & & & & & & & \\
\hline C54 & 0,93 & 1,00 & 1,00 & 0,88 & 1,00 & 0,81 & 1,00 & & & & & & & & & & & & & \\
\hline C55 & 0,93 & 1,00 & 1,00 & 0,88 & 1,00 & 0,81 & 1,00 & 1,00 & & & & & & & & & & & & \\
\hline C56 & 0,93 & 1,00 & 1,00 & 0,88 & 1,00 & 0,81 & 1,00 & 1,00 & 1,00 & & & & & & & & & & & \\
\hline CG57 & 0,88 & 0,86 & 0,86 & 0,83 & 0,86 & 0,90 & 0,86 & 0,86 & 0,86 & 1,00 & & & & & & & & & & \\
\hline C58 & 0,93 & 1,00 & 1,00 & 0,88 & 1,00 & 0,81 & 1,00 & 1,00 & 1,00 & 0,86 & 1,00 & & & & & & & & & \\
\hline C59 & 0,93 & 1,00 & 1,00 & 0,88 & 1,00 & 0,81 & 1,00 & 1,00 & 1,00 & 0,86 & 1,00 & 1,00 & & & & & & & & \\
\hline $\mathrm{C} 60$ & 0,93 & 1,00 & 1,00 & 0,88 & 1,00 & 0,81 & 1,00 & 1,00 & 1,00 & 0,86 & 1,00 & 1,00 & 1,00 & & & & & & & \\
\hline C61 & 0,88 & 0,95 & 0,95 & 0,83 & 0,95 & 0,81 & 0,95 & 0,95 & 0,95 & 0,90 & 0,95 & 0,95 & 0,95 & 1,00 & & & & & & \\
\hline CG62 & 0,88 & 0,86 & 0,86 & 0,83 & 0,86 & 0,90 & 0,86 & 0,86 & 0,86 & 1,00 & 0,86 & 0,86 & 0,86 & 0,90 & 1,00 & & & & & \\
\hline $\mathrm{C} 63$ & 0,88 & 0,95 & 0,95 & 0,83 & 0,95 & 0,81 & 0,95 & 0,95 & 0,95 & 0,90 & 0,95 & 0,95 & 0,95 & 1,00 & 0,90 & 1,00 & & & & \\
\hline C64 & 0,88 & 0,95 & 0,95 & 0,83 & 0,95 & 0,81 & 0,95 & 0,95 & 0,95 & 0,90 & 0,95 & 0,95 & 0,95 & 1,00 & 0,90 & 1,00 & 1,00 & & & \\
\hline CG65 & 0,95 & 0,88 & 0,88 & 0,90 & 0,88 & 0,93 & 0,88 & 0,88 & 0,88 & 0,93 & 0,88 & 0,88 & 0,88 & 0,83 & 0,93 & 0,83 & 0,83 & 1,00 & & \\
\hline CG66 & 0,88 & 0,86 & 0,86 & 0,83 & 0,86 & 0,90 & 0,86 & 0,86 & 0,86 & 1,00 & 0,86 & 0,86 & 0,86 & 0,90 & 1,00 & 0,90 & 0,90 & 0,93 & 1,00 & \\
\hline MD67 & 1,00 & 0,93 & 0,93 & 0,95 & 0,93 & 0,88 & 0,93 & 0,93 & 0,93 & 0,88 & 0,93 & 0,93 & 0,93 & 0,88 & 0,88 & 0,88 & 0,88 & 0,95 & 0,88 & 1,00 \\
\hline
\end{tabular}


APÊNDICE 25. Similaridades entre todos os genétipos da roça 1 de Praia Grande.

\begin{tabular}{|c|c|c|c|c|c|c|c|c|c|c|c|c|}
\hline Amostra & $\begin{array}{l}\mathrm{A01} \\
\text { (VO) }\end{array}$ & $\begin{array}{l}\mathrm{A03} \\
\text { (VO) }\end{array}$ & $\begin{array}{l}\text { A05 } \\
\text { VO) }\end{array}$ & $\begin{array}{l}\text { A07 } \\
\text { (VO) }\end{array}$ & $\begin{array}{l}\text { B23 } \\
\text { (VA) }\end{array}$ & $\begin{array}{l}\text { B25 } \\
\text { (VA) }\end{array}$ & $\begin{array}{l}\text { B26 } \\
\text { (VA) }\end{array}$ & $\begin{array}{l}\text { B43 } \\
\text { (VA) }\end{array}$ & $\begin{array}{l}\text { C51 } \\
\text { (PC) }\end{array}$ & $\begin{array}{l}\mathrm{C52} \\
(\mathrm{PC})\end{array}$ & $\begin{array}{l}\text { C63 } \\
\text { (PC) }\end{array}$ & $\begin{array}{l}\text { C77 } \\
\text { (PC) }\end{array}$ \\
\hline A01(VO) & 1,00 & & & & & & & & & & & \\
\hline A03(VO) & 0,76 & 1,00 & & & & & & & & & & \\
\hline A05(VO) & 0,86 & 0,90 & 1,00 & & & & & & & & & \\
\hline A07(VO) & 0,86 & 0,83 & 0,93 & 1,00 & & & & & & & & \\
\hline B23(VA) & 0,86 & 0,83 & 0,79 & 0,86 & 1,00 & & & & & & & \\
\hline B25(VA) & 0,79 & 0,90 & 0,86 & 0,93 & 0,93 & 1,00 & & & & & & \\
\hline B26(VA) & 0,93 & 0,76 & 0,86 & 0,93 & 0,93 & 0,86 & 1,00 & & & & & \\
\hline B43(VA) & 0,83 & 0,86 & 0,83 & 0,90 & 0,90 & 0,97 & 0,83 & 1,00 & & & & \\
\hline $\mathrm{C51}(\mathrm{PC})$ & 0,76 & 0,93 & 0,83 & 0,90 & 0,90 & 0,97 & 0,83 & 0,93 & 1,00 & & & \\
\hline C52(PC) & 0,83 & 0,86 & 0,90 & 0,97 & 0,83 & 0,90 & 0,90 & 0,86 & 0,93 & 1,00 & & \\
\hline $\mathrm{C63}(\mathrm{PC})$ & 0,72 & 0,83 & 0,79 & 0,86 & 0,86 & 0,93 & 0,79 & 0,90 & 0,90 & 0,83 & 1,00 & \\
\hline$C 77(P C)$ & 0,69 & 0,86 & 0,76 & 0,83 & 0,83 & 0,90 & 0,76 & 0,86 & 0,93 & 0,86 & 0,97 & 1,00 \\
\hline
\end{tabular}

APÊNDICE 26. Similaridades entre todos os genótipos da roça 2 de Praia Grande.

\begin{tabular}{lcccccc}
\hline Amostra & D091(PC) & D108(PC) & D112(PC) & D118(PC) & D134(PC) & D139(PC) \\
\hline D091(PC) & 1,00 & & & & & \\
D108(PC) & 0,97 & 1,00 & & & & \\
D112(PC) & 0,93 & 0,90 & 1,00 & & & \\
D118(PC) & 0,86 & 0,83 & 0,79 & 1,00 & & \\
D134(PC) & 0,86 & 0,83 & 0,93 & 0,72 & 1,00 & \\
D139(PC) & 0,93 & 0,90 & 0,86 & 0,79 & 0,93 & 1,00 \\
\hline
\end{tabular}

APÊNDICE 27. Similariedades entre todos os genótipos da roça 3 de Praia Grande.

\begin{tabular}{lllll}
\hline Amostras & E142(PC) & E147(PC) & E176(PC) & E235(PC) \\
\hline E142(PC) & 1,00 & & & \\
E147(PC) & 0,76 & 1,00 & & \\
E176(PC) & 0,83 & 0,93 & 1,00 & \\
E235(PC) & 0,83 & 0,93 & 0,86 & 1,00 \\
\hline
\end{tabular}

APÊNDICE 28. Similariedades entre todos os genótipos da roça 4 de Praia Grande.

\begin{tabular}{lrrrr}
\hline Amostras & F243(PC) & F321(PC) & F325(PC) \\
\hline F243(PC) & 1 & & \\
F321(PC) & 0,93 & 1 & \\
F325(PC) & 0,93 & 0,86 & 1 \\
\hline
\end{tabular}


APÊNDICE 29.Autovalores extraídos da análise de Coordenadas Principais para as três roças estudadas em Ariri 2.

Ariri 2 roça 1

Traço da matriz $=2,63401$

Variável autovalor

Coord. $1 \quad 1,25955$

Coord.2 $\quad 0,6112$

Coond. $3 \quad 0,47886$

Coord. $4 \quad 0,18833$

Coord. $5 \quad 0,06651$

Coord. $6 \quad 0,02948$

Coord. $7 \quad 0,00008$

Coord. $8 \quad 0$

Ariri 2 roça 2

Variância total $=1,11748$

\begin{tabular}{lcrr}
\hline Variável & Autovalor Proporção (\%) & Cumulativo (\%) \\
\hline Coord. 1 & 0,46354 & 41,48 & 41,48 \\
Coord. 2 & 0,31086 & 27,82 & 69,3 \\
Coord. 3 & 0,20482 & 18,33 & 87,63 \\
Coord. 4 & 0,10697 & 9,57 & 97,2 \\
Coord. 5 & 0,03127 & 2,8 & 100 \\
\hline
\end{tabular}

Ariri 2 roça 3

Variância total $=1,58096$

\begin{tabular}{lcrr}
\hline Variável & Autovalor Proporçăo(\%) & \multicolumn{1}{r}{ Cumulativo (\%) } \\
\hline Coord. 1 & 0,84158 & 53,23 & 53,23 \\
Coord. 2 & 0,46234 & 29,24 & 82,48 \\
Coord. 3 & 0,14746 & 9,33 & 91,8 \\
Coord. 4 & 0,09941 & 6,29 & 98,09 \\
Coord. 5 & 0,02483 & 1,57 & 99,66 \\
Coord. 6 & 0,00533 & 0,34 & 100 \\
\hline
\end{tabular}

